\title{
CLUSTER E COMPETITIVIDADE: UM ESTUDO DA CONCENTRAÇÃO DE MICRO E PEQUENAS EMPRESAS DE ALIMENTOS NO MUNICÍPIO DE MARÍLIA/SP
}

ANDRÉIA MARIZE RODRIGUES

Tese apresentada à Escola de Engenharia de São Carlos, da Universidade de São Paulo, como parte dos requisitos para obtenção do título de Doutor em Engenharia Mecânica.

ORIENTADOR: Prof. Dr. Arthur José Vieira Porto

São Carlos/SP

2003 


\section{AGRADECIMENTOS}

Meus sinceros agradecimentos ao Professor Arthur José Vieira Porto pela confiança em mim depositada e ao Professor Oswaldo Luiz Agostinho, pela oportunidade concedida.

Agradeço ao Professor Edmundo Escrivão Filho pelas fundamentais observações e sugestões apresentadas no exame de qualificação.

Ao estimado Professor Dário Henrique Alliprandini, pelas sugestões durante a execução deste trabalho.

Especiais agradecimentos ao Professor José Paulo Alves Fusco pela amizade, estímulo, sugestões e orientação.

Agradeço também ao Senhor Daércio Galati Vieira, da Adima - Associação das Indústrias de Alimentos de Marília, ao Senhor Arthur Eugênio Furtado Achôa, do Sebrae e às empresas e entidades pesquisadas pela fundamental colaboração para a realização desta tese.

À Coordenadoria de Aperfeiçoamento de Pessoal de Nível Superior - CAPES, pela bolsa de estudo concedida.

Agradeço ao apoio de meus pais e irmãos e em especial à minha irmã Béllll pela colaboração em mais esta jornada. Valeu!

Agradecimentos aos amigos Patty, Vânia, Maria Elena León Olave, Márcio A. R. Sanches, e, é claro, ao meu amado marido Gigi. 


\section{SUMÁRIO}

LISTA DE FIGURAS

LISTA DE TABELAS

LISTA DE ABREVIATURAS E SIGLAS iv

RESUMO

ABSTRACT vi

1. INTRODUÇÃO

$\begin{array}{ll}1.1 \text { Contextualização } & 02 \\ 1.2 \text { Objetivo da tese } & 04\end{array}$

$\begin{array}{ll}1.2 \text { Objetivo da tese } & 04\end{array}$

1.3 Motivação e justificativa da escolha do tema 06

$\begin{array}{ll}1.4 \text { Estrutura da tese } & 07\end{array}$

2. O CONTEXTO INDUSTRIAL CONTEMPORÂNEO E A

PRODUÇÃO DE ALIMENTOS

2.2 Os conceitos de Sistema Agroindustrial e Sistema Agroalimentar $\quad 15$

$\begin{array}{ll}2.3 \text { A indústria de alimentos no Brasil: características gerais } & 18\end{array}$

$\begin{array}{lr}\text { Sintese do Capítulo } & 20\end{array}$

3. COMPETITIVIDADE NO AGRONEGÓCIO 21

$\begin{array}{ll}3.1 \text { Competitividade e estratégias empresariais } & 21\end{array}$

$\begin{array}{ll}3.2 \mathrm{O} \text { conceito de competitividade regional } & 25\end{array}$

3.2.1 O papel das políticas públicas na competitividade regional 31

3.2.2 Competitividade regional e redes de poder territoriais 32

3.3 Competitividade regional e a produção de alimentos 34

$\begin{array}{ll}\text { 3.3.1 Diferenciação: os selos de origem } & 35\end{array}$

$\begin{array}{ll}\text { 3.3.2 Inovação } & 37\end{array}$

$\begin{array}{ll}\text { 3.3.3 Canais de distribuição } & 40\end{array}$

3.4 Principais opções estratégicas de firmas agroindustriais 43

Síntese do Capítulo $\quad 45$

4. MICRO E PEQUENAS EMPRESAS (MPE's) E REDES DE 46

\section{COOPERAÇÃO}

4.1 As micro e pequenas empresas no Brasil 46

4.2 Características gerenciais associadas às MPE's 48

4.3 A competitividade em micro e pequenas empresas $\quad 50$

4.4 Redes de cooperação $\quad 56$

4.5 Cluster: definição e principais características $\quad 61$

4.5.1 Os clusters e a competitividade regional 63

4.5.1.1 Economia $\quad 65$

4.5.1.2 Governos e Políticas $\quad 66$

4.5.1.3 Associações Comerciais e Órgãos Coletivos 68

4.5.2 O cluster completo $\quad 69$ 
4.5.3 Fatores fundamentais para a formação de redes de cooperação 72

4.5.3.1 Estrutura de Governança $\quad 72$

$\begin{array}{ll}\text { 4.5.3.2 Confiança (Trust) } & 73\end{array}$

$\begin{array}{lr}\text { Sintese do Capítulo } & 75\end{array}$

5. METODOLOGIA DE PESQUISA UTILIZADA 77

$\begin{array}{ll}\text { 5.1 Principais conceitos abordados neste trabalho } & 77\end{array}$

$\begin{array}{ll}5.2 \text { A pesquisa de campo } & 81\end{array}$

5.2.1 Tipificação da pesquisa de acordo com a abordagem $\quad 82$

$\begin{array}{ll}\text { 5.2.2 Métodos e instrumentos de pesquisa } & 83\end{array}$

$\begin{array}{lr}\text { 5.2.3 Projeto metodológico } & 85\end{array}$

5.3 Metodologia de pesquisa utilizada neste trabalho 86

$\begin{array}{lr}\text { 5.3.1 Objetivo da pesquisa } & 86\end{array}$

$\begin{array}{ll}\text { 5.3.2 Hipótese } & 86\end{array}$

$\begin{array}{ll}\text { 5.3.3 Proposições } & 87\end{array}$

$\begin{array}{ll}\text { 5.3.4.1 Etapa } 1 & 87\end{array}$

$\begin{array}{ll}\text { 5.3.4.2 Etapa } 2 & 90\end{array}$

$\begin{array}{ll}\text { Sintese do capítulo } & 102\end{array}$

6. ANÁLISE DO CLUSTER ALIMENTÍCIO DE MARÍLIA/SP 103

6.1 Etapa 1: a cidade de Marília como um cluster alimentício 103

$\begin{array}{ll}\text { 6.1.1 Aspectos gerais } & 103\end{array}$

6.1.2 Caracterização do cluster alimentício de Marília/SP 105

6.1.3 Considerações sobre a Etapa 1 da pesquisa 115

6.2 Etapa 2: a competitividade do cluster e Marília/SP 116

6.2.1 Análise da estrutura interna das empresas 117

6.2.1.1 Considerações sobre os dados da análise interna 143

6.2.2 Desempenho das empresas com relação aos fatores de
cooperação

6.2.2.1 Considerações sobre os fatores de cooperação 148

6.2.3 Análise Externa 149

6.2.3.1 Considerações sobre os dados da análise externa 157

6.3 Análise geral do cluster alimentício de Marília/SP 158

6.4 Ações para a dinamização da competitividade do cluster 163

$\begin{array}{ll}6.5 \text { Conclusão } & 164\end{array}$

7. CONSIDERAÇÕES FINAIS E PERSPECTIVAS 166

$\begin{array}{lr}\text { ANEXO I } & 169\end{array}$

$\begin{array}{lr}\text { ANEXO II } & 173\end{array}$

$\begin{array}{lr}\text { ANEXO III } & 177\end{array}$

REFERÊNCIAS BIBLIOGRÁFICAS 182

$\begin{array}{ll}\text { BIBLIOGRAFIA CONSULTADA } & 190\end{array}$ 


\section{LISTA DE FIGURAS}

FIGURA 2.1 - Sistema Agroindustrial - SAI

FIGURA 3.1 - Curva "U” e estratégias competitivas genéricas 23

FIGURA 3.2 - Cadeia de valor genérica em negócios industriais 24

FIGURA 3.3 - Competitividade segundo visão do IAD 26

FIGURA 3.4 - Determinantes de vantagem nacional $\quad 27$

FIGURA 3.5 - Modelo para análise da competitividade regional 29

FIGURA 3.6 - Os canais de distribuição para alimentos 42

FIGURA 4.1 - Ampliação das estratégias competitivas genéricas para MPE's $\quad 55$

FIGURA 4.2 - Redes de empresas dos tipos horizontal e vertical 57

FIGURA 4.3 - Modelo geral de rede para o desenvolvimento econômico local 64

FIGURA 5.1 - A influência das tendências do mercado nas empresas 78

FIGURA 5.2 - Aspectos relativos à competitividade empresarial e regional $\quad 79$

FIGURA 5.3 - Fatores relativos à competitividade de um cluster de alimentos considerados neste trabalho: modelo geral adotado para a pesquisa

FIGURA 5.4-Atividades da cadeia de valor utilizadas para a análise interna das empresas

FIGURA 6.1 - Sobrevivência e mortalidade acumulada das empresas do Estado de São Paulo

$\begin{array}{ll}\text { FIGURA 6.2 - Tempo de existência das empresas do cluster de Marília } & 107 \\ \text { FIGURA 6.3 - Principais matérias-primas utilizadas } & 110\end{array}$

FIGURA 6.4 - Localização dos fornecedores $\quad 112$

FIGURA 6.5 - Panorama geral do cluster alimentício de Marilia/SP 162 


\section{LISTA DE TABELAS}

$\begin{array}{lll}\text { TABELA 1.1 } & \text { Principais assuntos envolvidos neste trabalho } & 04\end{array}$

TABELA 1.2 Evolução da participação total de empregos por porte da 07

TABELA 2.1 Evolução dos Sistemas de Produção 13

TABELA 2.2 Dados gerais da indústria brasileira de alimentos 18 industrializados

TABELA 2.3 Variação anual em dados gerias da indústria brasileira de $\quad 19$ alimentos

TABELA 3.1 Riscos associados às estratégias genéricas

TABELA 3.2 Relação entre o mercado e o desempenho no tempo

TABELA 3.3 Descrição dos determinantes do "diamante" de Porter 28

TABELA 3.4 Evolução dos paradigmas competitivos 30

TABELA 3.5 Evolução geral das políticas industriais brasileiras ao 32

TABELA 3.6 Exemplos de sistemas de certificação de produtos 37

TABELA 3.7 Principais opções estratégicas associadas a firmas 44 agroindustriais

TABELA 4.1 Participação das MPE's na economia nacional 47

TABELA 4.2 Porte das empresas de acordo com os critérios 47 faturamento anual e número de funcionários

TABELA 4.3 Como os proprietários diferem dos "gerentes 49

TABELA 4.4 Principais características gerenciais associadas às 50 empresas de pequeno porte

TABELA 4.5 Vantagens e desvantagens associadas às MPE's 54

TABELA 4.6 Formas de cooperação entre empresas: rede de empresas $\quad 59$

TABELA 4.7 Formas de cooperação entre empresas: alianças 60 estratégicas

TABELA 4.8 Outras formas de cooperação entre empresas 60

TABELA 4.9 Vantagens associadas ao conceito de cluster 63

TABELA 4.10 Fontes de cooperação 73

TABELA 4.11 Três níveis para lidar com o risco da cooperação 74

TABELA 5.1 Comparativo entre as abordagens 83

TABELA 5.2 Principais métodos de pesquisa e instrumentos utilizados na EP

TABELA 5.3 Indicativos para a escolha do método de pesquisa 84

TABELA 5.4 Resumo do projeto metodológico da pesquisa (Etapa 1) 88

TABELA 5.5 Entidades fornecedoras das listagens das empresas de alimentos de Marília

TABELA 5.6 Resumo do projeto metodológico da pesquisa (Etapa 2 -Parte A)

TABELA 5.7 Resumo do projeto metodológico da pesquisa (Etapa 2 Parte B)

TABELA 6.1 Porte das empresas processadoras de alimentos do cluster alimentício de Marília/SP 
TABELA 6.2 Total de empregos gerados

TABELA 6.3 Linhas de produtos fabricados

TABELA 6.

Destino das vendas das empresas do cluster

TABELA 6.5 Volume de matérias-primas consumidas

TABELA 6.6 Principais dificuldades operacionais enfrentadas pelas empresas

TABELA 6.7 Principais dificuldades enfrentadas no aporte de matérias-

TABELA 6.8 primas

TABELA 6.9 Empresas do cluster pesquisadas

TABELA 6.10 Impressões sobre a Empresa 1 sobre entidades do tecido institucional

TABELA 6.11 Impressões sobre a Empresa 2 sobre entidades do tecido institucional

TABELA 6.12 Impressões sobre a Empresa 3 sobre entidades do tecido institucional

TABELA 6.13 Impressões sobre a Empresa 4 sobre entidades do tecido institucional

TABELA 6.14 Impressões sobre a Empresa 5 sobre entidades do tecido institucional

TABELA 6.15 Impressões sobre a Empresa 6 sobre entidades do tecido institucional

TABELA 6.16 Impressões sobre a Empresa 7 sobre entidades do tecido institucional

TABELA 6.17 Impressões sobre a Empresa 8 sobre entidades do tecido institucional

TABELA 6.18 Impressões sobre a Empresa 9 sobre entidades do tecido institucional

TABELA 6.19 Impressões sobre a Empresa 10 sobre entidades do tecido institucional

TABELA 6.20 Dados da pesquisa coletados para a análise interna 144

TABELA 6.21 Características presentes no cluster de Marilia 160

$\begin{array}{ll}\text { TABELA 6.22 Características ausentes no cluster de Marilia } & 160\end{array}$ 


\title{
LISTA DE ABREVIATURAS E SIGLAS
}

\author{
MPE - Micro e Pequena Empresa \\ PME - Pequena e Média Empresa \\ MPME - Micro, Pequena e Média Empresa \\ PE - Pequena Empresa \\ MGE - Médias e Grandes Empresas
}




\section{RESUMO}

RODRIGUES, A.M. Chuster e competitividade: um estudo da concentração de micro e pequenas empresas de alimentos no município de Marilia/SP. São Carlos, 2003. 191p. Tese (Doutorado) - Escola de Engenharia de São Carlos, Universidade de São Paulo.

Nas últimas décadas, o cenário empresarial mundial tem presenciado profundas modificações que afetam diretamente as empresas e definem novas formas de atuação no mercado. Por um lado, pode-se identificar a posição de destaque ocupada pelos consumidores, ávidos por produtos e serviços de alta qualidade e que de fato atendam às suas necessidades. Por outro, destaca-se o fenômeno da globalização dos mercados e seu reflexo na concorrência entre as empresas, que agora passa a ser mundial. Além disto, esta troca de paradigmas traz em seu bojo mudanças nos fatores definidores de competitividade para as empresas. Esta situação desfavorece, sobretudo, as micro e pequenas empresas (MPE's), que muitas vezes não contam com capacidade competitiva necessária para se adaptarem a esta nova era. Para sobreviver às condições impostas pela economia vigente, observâ-se o surgimento de novas formas de organização industrial, com destaque às que estimulam a cooperação entre empresas de um mesmo setor ou de setores complementares, dentre os quais destacam-se os chamados aglomerados ou clusters. Pelas suas características, a presença em um cluster possibilita às MPE's incrementos em seus processos produtivos, tanto em termos de volume de produção quanto em termos de aumento de possibilidades tecnológicas, através do compartilhamento de meios produtivos e de investimentos na busca por melhores tecnologias, sejam elas de produto, de processo ou de gestão. De acordo com este cenário, o objetivo desta tese consiste em desenvolver uma análise da competitividade das MPE's do cluster alimentício do município de Marília/SP, possibilitando identificar ações a serem tomadas para o aumento da competitividade deste conjunto de empresas. Para a realização desta análise foi elaborado um modelo geral adotado na pesquisa, considerando as particularidades do cluster em questão: a predominância de MPE's e as características da indústria alimentícia.

Palavras-chave: cluster, competitividade, agroindístria, MPE's. 


\section{ABSTRACT}

RODRIGUES, A.M. Cluster and competitiveness: an analysis of the concentration of small food industries in the city of Marilia-SP. São Carlos, 2003. 191p. Tese (Doutorado) - Escola de Engenharia de São Carlos, Universidade de São Paulo.

In the last decades, the managerial scenery in the world has been witnessing deep modifications that affect the companies directly and define its new forms of performance in the market. On one side, it can be verified the prominent position occupied by the consumers, avid for products and services of high quality and that in fact assist to their needs. On other side, it can be stand out the phenomenon of the globalization of the markets, enlarging the horizons of the companies for besides the national limits, increasing, with that, the competition among them. Besides this, this change of paradigms brings in its core some changes in the factors that define the competitiveness for a company. This situation disfavors, above all, the small firms, that don't have necessary competitive capacity for adapt itself to this new era. Thus, to survive to the conditions imposed by the effective economy, these firms create new ways of industrial organization that stimulate cooperation among companies that belongs to the same sector or to the complementary sectors, which can be stand out as agglomerates or clusters. For its characteristics, the presence in a cluster facilitates to the MPE's increments in its productive processes, so much in terms of production volume as in terms of increase of technological possibilities, through the share alike of productive means and of investments in the search for better technologies, be them of product, of process or of administration. In agreement with this scenery, the objective of this thesis consists of developing an analysis of the competitiveness of MPE's agroindustrial cluster in the municipal district of Marilia/SP, facilitating to identify actions to be taken for the competitiveness increasing of this group of companies. For the accomplishment of this analysis a general model adopted in the research was elaborated, considering the particularities of the cluster in subject: the predominance of MPE's and the characteristics of the nutritious industry.

Keywords: cluster, small firms competitiveness, agroindustry. 


\section{INTRODUÇÃO}

A idéia do estudo da competitividade de micro e pequenas empresas começou a ser concebida no primeiro semestre do ano de 2001, na cidade de Marília, interior de São Paulo. Nesta época, iniciou-se uma pesquisa com o propósito de realizar um diagnóstico das empresas da indústria alimentícia local, uma vez que esta indústria possui uma representatividade significativa para a cidade, principalmente em termos do número de empresas do setor ali presentes, constituindo um aglomerado ou um cluster alimentício. Por este motivo, o município chega a se auto-intitular de "Capital Nacional do Alimento".

Assim, como ponto de partida para a realização do referido diagnóstico, deu-se início à busca de dados acerca das empresas locais processadoras de alimentos. Com o decorrer da pesquisa, entretanto, deparou-se com vários obstáculos causados pela escassez de informações, inclusive com a falta de uma listagem completa e atualizada sobre o conjunto de empresas em questão.

Este ponto, em especial, levou à seguinte reflexão: como um município que ostenta o título de "capital do alimento" deseja tirar proveito mercadológico disto sem possuir conhecimento exato de seu parque industrial?

Apesar das dificuldades iniciais encontradas, o estudo prosseguiu e, mais uma vez, deparou com outros resultados inesperados: o parque industrial composto pelas empresas de alimentos, apesar de bastante significativo, é bem menor do que o previsto e divulgado pelas entidades locais. Além disto, a grande maioria das empresas alimentícias do município são de micro e pequeno porte e carecem de recursos de toda ordem, imperando a desatualização tecnológica e a falta de conhecimento sobre ferramentas básicas de gestão.

Estes resultados preliminares, deparados com a lógica imposta pela mudança dos fatores competitivos inerente ao processo de globalização, levam a crer que não tarda o desaparecimento destas MPE's do cenário empresarial. Assim, se o município deseja aproveitar economicamente dos benefícios de sua aglomeração de empresas 
de alimentos, seria necessário, inicialmente, o conhecimento de sua real posição competitiva, para que, então, sejam indicadas ações capazes de dinamizar a reestruturação tanto interna às empresas (fatores estruturais e infra-estruturais) quanto externa a elas (no ambiente institucional), visando capacitá-las para competir no cenário atual.

Assim, partindo desta premissa e mediante o contexto da globalização, como este cluster alimentício está configurado no que se refere à competitividade das MPE's que o compõem? A busca da resposta a esta pergunta norteou a execução deste trabalho.

\subsection{Contextualização}

Nas últimas décadas, o cenário empresarial tem presenciado profundas modificações mundiais que afetam diretamente as empresas e definem novas formas de atuação no mercado.

Por um lado, cita-se a posição de destaque ocupada pelos consumidores, ávidos por produtos e serviços de alta qualidade e que de fato atendam às suas necessidades. Além disto, a preocupação dos clientes com a procedência e segurança dos produtos, sobretudo com os agroalimentares, tem tomado proporções cada vez maiores. É crescente a busca e a aceitação de produtos que possuem os chamados "selos de origem”, que certificam ao consumidor a procedência geográfica do produto, podendo esta diferenciação ser utilizada como vantagem competitiva para produtos produzidos em um dado local ou região (Barzel, 1982; Becattini, 1994; Porter, 1998).

Por outro lado, destaca-se o fenômeno da globalização dos mercados, ampliando os horizontes das empresas para além dos limites nacionais, aumentando, com isso, a concorrência, que agora passa a ser mundial (Humphrey \& Schimitz, 2000). Além disto, esta troca de paradigmas traz em seu bojo mudanças nos fatores definidores de competitividade para uma empresa. O conceito de qualidade, em sua dimensão de conformidade física, por exemplo, passa a ser uma commodity nesta era de produção enxuta, onde imperam os fatores tempo e flexibilidade.

Esta situação desfavorece, sobretudo, as micro e pequenas empresas (MPE’s), que muitas vezes não contam com capacidade competitiva necessária para se 
adaptarem a esta nova era. No Brasil, segundo dados do IBGE, as micro e pequenas empresas executam um papel importante na economia nacional, uma vez que $98 \%$ das empresas brasileiras se constituem em empresas de micro e pequeno porte, sendo estas responsáveis por 59\% dos empregos gerados no país.

Para sobreviver às condições impostas pela economia vigente, observa-se o surgimento de novas formas de organização industrial, com destaque às que estimulam as cooperações entre empresas de um mesmo setor ou de setores complementares (Ingley, 1999; Amato Neto, 1999). Estas relações entre empresas, também chamadas de redes de cooperação, podem se dar de várias maneiras. Temos como exemplos os consórcios, as alianças, parcerias, joint-ventures, clusters, entre outros, e cada uma destas enfoca interações específicas entre empresas. Dentre estes arranjos, destacam-se os chamados aglomerados ou clusters, que, de acordo com Porter (1998) se constituem em concentrações geográficas de empresas e instituições, ligadas por aspectos que podem ser compartilhados e complementados entre si. Estas empresas cooperam e colaboram para o desenvolvimento de vantagens econômicas e estratégicas.

Os clusters, então, possibilitam às micro e pequenas empresas incrementos em seus processos produtivos, tanto em termos de volume de produção quanto em termos de aumento de possibilidades tecnológicas, através do compartilhamento de meios produtivos e de investimentos na busca por melhores tecnologias, sejam elas de produto, de processo ou de gestão. Outra vantagem associada aos clusters seria a promoção dos produtos produzidos no local, uma vez que a falta de uma marca forte ou de um nome representativo que defina o(s) produto(s) produzido(s) por uma empresa isolada, pode levar a dificuldades de inserção do(s) seu(s) produto(s) no mercado e à restrição ao acesso a canais de distribuição fortes.

A cooperação entre empresas pode, ainda, proporcionar inúmeras outras vantagens, como o aumento de flexibilidade e agilidade no atendimento de pedidos com relação a uma grande empresa operando sozinha.

De acordo com Paulillo (2000, p. 5), “o território, como uma construção social e política, é vetor de uma nova postura estratégica para algumas políticas agroindustriais no Brasil: o de pensar globalmente e agir localmente". Este trabalho procura a contextualização da competitividade de MPE's de alimentos em âmbito 
"global" para, então, buscar no "local" os argumentos para as ações que garantam a força competitiva destas empresas.

\subsection{Objetivo da Tese}

De acordo com o cenário exposto no tópico anterior, o objetivo desta tese consiste em efetuar uma análise crítica da competitividade do cluster alimentício de Marília/SP, enfocando, especificamente, as micro e pequenas empresas e, através desta análise, elencar as possíveis ações a serem tomadas para o aumento da competitividade deste conjunto.

Pela definição do objetivo deste trabalho, pode-se elencar três grandes conjuntos de assuntos que envolvem esta pesquisa, demonstrados na Tabela 1.1.

TABELA 1.1: Principais assuntos envolvidos neste trabalho.

\begin{tabular}{|l|l|}
\hline \multicolumn{1}{|c|}{ Assunto } & \multicolumn{1}{c|}{ Razões } \\
\hline \hline $\begin{array}{l}\text { Características do panorama } \\
\text { industrial contemporâneo e e } \begin{array}{l}\text { O estudo das características do ambiente industrial contemporâneo tem } \\
\text { Sistema Agroindustrial }\end{array}\end{array}$ & $\begin{array}{l}\text { como principal objetivo a contextualização do leitor com relação às } \\
\text { características prevalecentes no cenário mundial dos negócios. } \\
\text { Pelo fato deste estudo focar, especificamente, na produção de alimentos, } \\
\text { uma explanação das mudanças ocorridas neste setor também se faz } \\
\text { necessária. }\end{array}$ \\
\hline Competitividade no agronegócio & $\begin{array}{l}\text { Perante as principais características do ambiente dos negócios, torna-se } \\
\text { importante o estudo dos fatores que definem a competitividade para o setor } \\
\text { agroalimentar e das opções estratégicas para as empresas de alimentos. }\end{array}$ \\
\hline $\begin{array}{l}\text { Micro e pequenas empresas e e } \\
\text { redes de cooperação }\end{array}$ & $\begin{array}{l}\text { Mediante o cenário contemporâneo dos negócios e os fatores competitivos } \\
\text { por ele definidos, é necessário que se faça a contextualização das MPE's. } \\
\text { Tendo como pano de fundo as diferenças que caracterizam estas empresas } \\
\text { com relação às empresas de grande porte, são apresentadas as redes de } \\
\text { empresas como opção estratégica para o aumento de sua competitividade. }\end{array}$ \\
\hline
\end{tabular}

Para tanto, esta tese conta com as seguintes etapas:

1. Revisão da literatura sobre o panorama industrial atual, sobretudo para o setor agroalimentar. Nesta etapa também é realizada a contextualização da indústria de alimentos no Brasil, com a apresentação de dados sobre o setor.

2. Revisão da literatura sobre os conceitos de competitividade empresarial e regional, visando obter argumentos para a análise competitiva do cluster em questão. 
3. Revisão da literatura sobre os conceitos de micro e pequenas empresas e redes de cooperação produtiva.

4. Estudo preliminar para a quantificação e qualificação das empresas da indústria alimentícia de Marília, já que nenhuma entidade, seja ela pública ou privada, contava com um cadastro atualizado acerca das empresas de alimentos ativas na cidade na época de realização da pesquisa (início de 2001). Esta etapa conta também com o levantamento dos atores individuais e coletivos, públicos e privados que fazem parte do ambiente em questão.

5. Estudo da competitividade do cluster:

* Primeira parte: estudo de uma amostra aleatória de MPE's para o conhecimento de características específicas relativas à competitividade de seu ambiente interno, incluindo fatores associados à cooperação entre as empresas.

* Segunda parte: estudo da competitividade relativa aos fatores ligados ao ambiente institucional do referido cluster (entidades de classe, sindicatos, prefeitura, entre outros).

6. Análise crítica da competitividade do cluster em questão, e posterior proposta de ações que podem ser tomadas, tanto pelas MPE's quanto pelas instituições presentes no cluster, para que sejam dinamizadas as características competitivas do mesmo.

7. Conclusões do trabalho e propostas de alternativas para a continuidade e aprofundamento do estudo realizado.

\subsection{Motivação e justificativa da escolha do tema}

Conforme já comentado no início deste texto, as condições e características encontradas na cidade de Marília, interior de São Paulo, se apresentam como as razões fundamentais para a realização deste trabalho. A cidade se autodenomina a "Capital Nacional do Alimento", com a presença de micro e pequenas empresas processadoras de alimentos compondo a maior parte de seu setor industrial, 
formando, assim, um cluster alimentício. Desta maneira, nota-se no município manifestações no sentido de se aproveitar das vantagens desta aglomeração, embora sejam elas realizadas de uma forma incipiente, carecendo de conhecimentos e informações a respeito do contexto teórico acerca de aglomerados.

Além disto, qualquer tipo de iniciativa de articulação entre estas empresas, fosse ela pública ou privada, encontrava-se limitada pela falta de informações concretas, e não especulativas, sobre o setor. Isso porque, no início desta pesquisa, a cidade carecia de todo tipo de informação a respeito do setor alimentício, tais como número e porte das empresas, linha de produtos fabricados, empregos gerados, entre outros.

Ao se realizar, então, um levantamento geral sobre as empresas presentes no município, pode-se caracterizar o cluster: dentre o setor alimentício, $75 \%$ das empresas processadoras são de micro e pequeno porte e possuem baixos níveis de cooperação entre si e quase nenhum conhecimento sobre as reais vantagens desta concentração geográfica.

De acordo com esta caracterização inicial, pode-se elencar três pontos principais encontrados neste cluster que estimularam e nortearam a execução deste trabalho, justificando, assim, sua realização.

Em primeiro lugar, destaca-se a posição preocupante ocupada pelas micro e pequenas empresas em face às grandes transformações mundiais ocorridas no cenário econômico. Estas empresas, que segundo dados do IBGE representam 98\% das empresas brasileiras, empregam 59\% do pessoal ocupado no país, sendo esta uma tendência em ascensão, conforme demonstrado pela Tabela 1.2. Desta maneira, é clara a importância das MPE's dentro da economia nacional e estudos que reforcem a competitividade destas empresas se mostram bastante relevantes. Além disto, conforme discutido por Las Casas (2001), apesar da relevância das MPE's, a literatura existente ainda carece de estudos e textos que abordem especificamente a problemática relativa às empresas deste porte.

Em segundo lugar, a indústria de alimentos apresenta características bastante particulares. Esta indústria, por exemplo, é considerada estratégica para a economia nacional, pois ameniza oscilações em períodos críticos e funciona como um "colchão amortecedor", uma vez que se compõe de bens de consumo essencial, cuja 
sensibilidade a variações são menores (Sato, 1997) (Abia, 1999). Destaca-se, ainda, a crescente preocupação do consumidor com a procedência dos produtos alimentícios, fator este que pode ser contemplado em um estudo desta natureza.

TABELA 1.2: Evolução da participação total de empregos por porte da empresa.

\begin{tabular}{|c|c|c|c|}
\hline \multirow{2}{*}{ Perfil da empresa } & \multicolumn{2}{|c|}{ Participação total de empregos } & Variação no \\
& Ano: 1995 & Ano: 2000 & período \\
\hline Grandes & $36 \%$ & $34 \%$ & $-2 \%$ \\
\hline Médias & $22 \%$ & $29 \%$ & $-2 \%$ \\
\hline Pequenas & $19 \%$ & $29 \%$ & $+1 \%$ \\
\hline Micros & $23 \%$ & $26 \%$ & $+3 \%$ \\
\hline
\end{tabular}

Fonte: "O crescimento das menores". Revista Veja. ed. 1734, ano35, n.2.(16/01/2002). p.24.

Por fim, em face à realidade econômica, nota-se o surgimento de novas estruturas organizacionais, com destaque aos arranjos cooperativos entre empresas, também chamados de redes de cooperação. Estas estruturas possuem especial valor para as empresas de menor porte, uma vez que acenam para as mesmas como uma alternativa para sua permanência e estabilidade no mercado. Esta cooperação pode se dar tanto em termos produtivos quanto comerciais ou tecnológicos e se apresenta como uma alternativa para que haja a sinergia desejada entre as empresas presentes no cluster. Desta maneira, a concentração geográfica de empresas do município de Marília pode apresentar para as MPE's locais um diferencial significativo rumo à sua competitividade, merecendo estudos com relação à dinamização da cooperação entre as mesmas.

\subsection{Estrutura da Tese}

Este trabalho conta com os seguintes capítulos:

1. Introdução

2. O contexto industrial contemporâneo e a produção de alimentos

3. Competitividade no agronegócio 
4. Micro e pequenas empresas (MPE's) e redes de cooperação

5. Metodologia utilizada

6. Análise do cluster alimentício de Marília/SP

7. Considerações finais e perspectivas

Desta forma, em um primeiro momento (capítulo 2) é feita uma descrição do contexto industrial contemporâneo, destacando, sobretudo, as características presentes no ambiente do agronegócio. Neste mesmo capítulo são apresentados alguns dados relativos à indústria brasileira de alimentos

$\mathrm{Na}$ sequência (capítulo 3) são revisados os conceitos de competitividade empresarial e regional e são discutidos alguns fatores competitivos para o setor de alimentos.

No capítulo 4 encontram-se a caracterização das micro e pequenas empresas, seus fatores de competitividade e a discussão da possibilidade de auferir às mesmas vantagens competitivas através da formação de redes de cooperação. Dentro deste último assunto, são enfocados, especificamente, os arranjos entre empresas de um mesmo território (cluster), objeto de análise deste trabalho.

A metodologia utilizada por este trabalho compõe o capítulo 5.

A caracterização do objeto de pesquisa deste estudo - o cluster de Marília bem como a análise da sua competitividade são realizadas no capítulo 6 .

E, por fim, no capítulo 7 são traçadas as considerações finais e são propostas alternativas para a continuidade e aprofundamento do estudo realizado.

Desse modo, os três próximos capítulos tratam da revisão bibliográfica, visando amparar o trabalho e buscar base comprovada cientificamente para o desenvolvimento da pesquisa. 


\section{O CONTEXTO INDUSTRIAL CONTEMPORÂNEO E A PRODUÇÃO DE ALIMENTOS}

Vivencia-se hoje no meio industrial a chamada era da lean production ou produção enxuta. Este sistema de produção apresenta características bem marcantes, fruto da evolução dos sistemas de produção anteriores (sistema de produção artesanal e em massa).

As paulatinas transformações ocorridas nesta evolução deram origem a novos paradigmas associados à produção industrial e ao gerenciamento de empresas, determinando novos padrões de comportamento para as organizações. Desta forma, este capítulo se divide em dois pontos principais. Em um primeiro momento são feitas considerações sobre o sistema de produção vigente, partindo de uma revisão das principais características presentes desde os sistemas de produção anteriores até a era atual, dando destaque às mudanças específicas ocorridas no cenário agroindustrial, no qual se inserem as empresas estudadas neste trabalho.

Num segundo momento, é feita a caracterização da indústria brasileira de alimentos com a apresentação de dados referentes ao setor.

\subsection{Evolução no cenário empresarial e seus reflexos no agronegócio}

A produção artesanal, existente desde a era feudal, apresenta como principais características a produção em pequena escala e o gerenciamento de todas as etapas produtivas realizado pelo artesão proprietário da pequena empresa, assim chamada de oficina. Esta empresa possuía uma organização tradicional, onde o ofício era passado do artesão mestre para pessoas escolhidas, os aprendizes, e a relação de trabalho entre esses eram bastante pessoais (Sistema de Produção Artesanal).

A possibilidade de mecanização da produção advinda da Revolução Industrial bem como a divisão do trabalho refletiram de maneira significativa no aumento dos volumes de produtos fabricados pelas empresas. $\mathrm{O}$ aumento da capacidade produtiva 
deu origem à grande indústria seriada, surgindo aí as bases para o Sistema de Produção em Massa. Esta organização produtiva dos primórdios da industrialização em massa passou por uma fase de burocratização, que, segundo Weber ${ }^{1}$, se constitui no tipo ideal de organização, caracterizado por três elementos fundamentais: formalidade dos procedimentos administrativos, impessoalidade nas relações existentes na empresa e gerência da organização feita por profissionais (profissionalismo). Estas características moldaram para sempre a organização, uma vez que estabeleceram papéis bem definidos para todos os seus membros.

Neste sistema de produção e acumulação de capital, também chamado de fordista, os processos produtivos se caracterizam pela intensa racionalização e mecanização, com foco na produção em grande escala e a baixos custos. A qualidade, por sua vez, é avaliada estritamente em relação às especificações do produto e a padronização de produtos marca fortemente este período (Bonanno, 1999).

Com relação à agricultura e à agroindústria, a oferta de alimentos segue o mesmo caminho, tornando-se abundante, porém padronizada, girando em torno de produtos tradicionais como pão, leite, manteiga. Este modo de organização e padrão de consumo alimentar é chamado por Friedman (1991) de Primeiro Regime Alimentar.

A ascensão e a consolidação do modelo de produção em massa ocorre em um período onde o Estado marca forte presença na esfera econômica e na promoção do bem-estar social. Assim, com a força de trabalho pacificada por altos salários, a classe média cresce, juntamente com a elevação de seu nível de vida e consequente aumento de seu poder de consumo.

No início da década de 70, entretanto, começam a aparecer sinais da decadência deste modelo de produção e acumulação de capital. $\mathrm{O}$ acirramento da competição global em paralelo com o enfraquecimento do Estado devido a crises econômicas, políticas e sociais, levaram a um reposicionamento estratégico das empresas, dando origem ao Sistema de Produção Enxuta, também chamado de pós-fordismo global.

Este novo modelo de produção e acumulação de capital centra-se fortemente na mobilidade global, uma vez que a insatisfação social gerada pela crise do Estado na

\footnotetext{
${ }^{1}$ Para maiores informações sobre o trabalho de Max Weber vide, por exemplo: WEBER, M. "Economia e
} 
manutenção do bem-estar social leva as empresas a se instalarem em locais onde haja menor pressão dos grupos subordinados.

As empresas passam a possuir tal flexibilidade que lhes permite mudar suas plantas e ativos ao redor do mundo, em busca de melhores resultados em termos de acumulação de capital, através de trabalhadores menos sindicalizados, salários mais baixos, leis ambientais mais flexíveis ou, ao contrário, de trabalhadores mais qualificados e melhores condições infra-estruturais (Bonanno, 1999).

Além disto, ressalta-se a mudança de comportamento dos consumidores, tornando-se mais exigentes com relação aos produtos adquiridos, buscando bens que de fato atendam às suas necessidades. Este fator, aliado ao aumento da competição empresarial, leva à necessidade das empresas adaptarem seus meios produtivos à flexibilidade e à inovação constante de seus produtos. Isto faz com que as empresas do mundo inteiro comecem a ficar atentas aos resultados alcançados pela empresa japonesa Toyota que, através de programas de eliminação de desperdícios e de melhoria contínua em produtos e processos, geraram resultados surpreendentes em termos produtivos e na flexibilização da produção, levando ao advento do paradigma tecnológico da microeletrônica e dos chamados sistemas flexíveis de manufatura.

Assim, a empresa passa a se orientar para os clientes e a produção perde seu caráter padronizado, uma vez que o sucesso da empresa passa a estar ligado à sua capacidade em antecipar mercados e responder rápida e eficientemente às demandas com produtos que satisfaçam aos consumidores. A produção se volta, então, para mercados globais cada vez mais segmentados.

Seguindo esta linha, a agricultura e a agroindústria também sofrem modificações em direção à flexibilização, com mudanças nos produtos, nos processos de fabricação, nas formas de organização das empresas e no papel dos Estado. Os espaços nacionais deixam de ser referência, entrando em cena a divisão internacional do trabalho coordenada por firmas transnacionais.

Inicia-se um processo de "descomoditização" dos produtos alimentícios, uma vez que a especialização flexível, que marca a produção deste período, leva à diversificação de mercados e à valorização de atributos como qualidade e reflexos ambientais da produção (Romano, 1999). 
Além da diversificação das commodities, o setor agroindustrial também passa por um crescimento na segmentação do mercado, ocasionando aumentos cada vez maiores na diversidade dos produtos lançados. Como consequência, as empresas do setor se viram compelidas ao desenvolvimento de estratégias de diferenciação de produtos para se destacar dos seus concorrentes (Neves et al., 2000). Isto tudo leva ao aparecimento de produtos direcionados a seguimentos específicos do mercado, tais como:

- produtos voltados a atender faixas etárias definidas (crianças, adolescentes e idosos);

- produtos com atributos que valorizam aspectos religiosos e culturais;

- produtos que buscam atender consumidores que valorizam empresas e produtos com performance ambientalmente corretas;

- produtos que procuram atender consumidores preocupados com a saúde e forma física ( linhas diet ou light), entre outros.

Assim, de acordo com a classificação atribuída a Friedman (1991), este novo padrão de produção e consumo de alimentos presente no pós-fordismo marca a mudança do Primeiro para o Segundo Regime Alimentar.

Ressalta-se, entretanto, que, apesar desta transição nos sistemas de produção discutida que culmina no Sistema de Produção Enxuta, muitas empresas ainda operam de acordo com as características que definem os dois sistemas anteriores (Produção Artesanal e em Massa). Isto ocorre principalmente pela falta de condições tanto financeiras e tecnológicas quanto de gestão para operar conforme os itens que definem o Sistema de Produção Enxuta.

A tabela 2.1 resume a evolução ocorrida nos sistemas de produção. 
TABELA 2.1: Evolução dos Sistemas de Produção

\begin{tabular}{|l|l|l|l|l|l|}
\hline $\begin{array}{c}\text { Sistema de } \\
\text { Produção }\end{array}$ & \multicolumn{1}{|c|}{ Período } & $\begin{array}{c}\text { Tipo de } \\
\text { Organização }\end{array}$ & Características das empresas & Características do ambiente \\
\hline Artesanal & $\begin{array}{l}\text { Até início do } \\
\text { século XX }\end{array}$ & Tradicional & $\begin{array}{l}\text { Produção em pequenas } \\
\text { quantidades de produtos sob } \\
\text { encomenda. }\end{array}$ & $\begin{array}{l}\text { Demanda por produtos sob } \\
\text { encomenda. }\end{array}$ \\
\hline $\begin{array}{l}\text { Massa } \\
\text { (fordismo) }\end{array}$ & $\begin{array}{l}\text { Início do século à década de } \\
1970\end{array}$ & Burocrática & $\begin{array}{l}\text { Grande quantidade de } \\
\text { unidades produzidas com } \\
\text { enfoque no baixo custo. }\end{array}$ & $\begin{array}{l}\text { Forte presença do Estado. } \\
\text { Produção de commodities. } \\
\text { Agroindústria: Primeiro } \\
\text { Regime Alimentar. }\end{array}$ \\
\hline $\begin{array}{l}\text { Enxuta } \\
\text { (pós- } \\
\text { fordismo) }\end{array}$ & $\begin{array}{l}\text { Década de 1970 } \\
\text { em diante }\end{array}$ & Burocrática & $\begin{array}{l}\text { Eliminação de desperdícios, } \\
\text { melhoria contínua das } \\
\text { operações. Produção flexivel. }\end{array}$ & $\begin{array}{l}\text { Enfraquecimento do poder } \\
\text { do Estado. Mobilidade } \\
\text { global das empresas. } \\
\text { Diversificação de produtos. } \\
\text { Agroindústria: } \\
\text { Regime Alimentar. }\end{array}$ \\
\hline
\end{tabular}

Como visto, o sistema de produção enxuta em vigor traz em seu bojo características que provocaram mudanças substanciais na manufatura das empresas, com destaque ao conceito de manufatura ágil e flexível (Kidd, 1994). Manufatura ágil diz respeito à capacidade da empresa em responder rapidamente e com qualidade a demandas por produtos customizados e manufatura flexível é a capacidade de absorver e atender às variações nestas demandas.

As mudanças ocorridas no cenário dos negócios somada à recessão mundial ocorrida no final dos anos 80 e início dos 90, levaram as empresas a reexaminarem, em um nível estratégico, as trajetórias escolhidas tanto para agregar valor quanto para reduzir custos de seus produtos para o consumidor final. As mudanças resultantes desta análise foram programas de downsizing, redução em custos, programas de melhoramento contínuo da qualidade e programas de redução de inventários.

Para tanto, as empresas passaram a se concentrar em suas competências principais (core competences), ou seja, no que a empresa faz que de fato diferencia seu produto dos concorrentes (Harland et al., 1999) (Parolini, 1999). Este foco levou as empresas a terceirizarem (outsourcing) as demais atividades (non-competences) e a utilizarem parceiros externos como fontes complementares de conhecimento e competências (Nooteboom, 1999). 
De acordo com o conceito de cadeia de valor $^{2}$ (Porter, 1990), as empresas estariam, então, repassando para empresas terceiras as atividades da cadeia que não influenciam na competitividade do produto final, passando, então, a se concentrar nas chamadas atividades - chave.

Esta tendência ao outsourcing, em contraste ao paradigma de integração vertical em voga até então (realização de todas as atividades da cadeia por uma única empresa), expandiu a visão dos negócios de uma empresa de suas próprias fronteiras para um encadeamento de empresas, com cada uma delas focando em sua core competence.

Atualmente, para a visualização de um dado negócio é necessário ultrapassar os limites de uma única empresa, expandindo a visualização para todas as empresas que constituem uma dada cadeia produtiva.

Pela perspectiva sistêmica, a compreensão do processamento industrial não mais se dá apenas pela análise do desempenho de uma única empresa. Para a produção de um dado bem, é necessário que haja uma seqüência de operações, que começam na aquisição da matéria-prima, passando pelo conjunto de processamentos necessários para a transformação do bem, incluindo a distribuição física, até o produto chegar às mãos do consumidor.

De acordo com esta perspectiva, na maioria das vezes é necessário que mais de uma empresa participe desta seqüência de operações, uma vez que a integração vertical não mais se apresenta como a melhor alternativa estratégica.

Dentro deste contexto está a definição de cadeia de produção, representando esta seqüência de operações que leva à produção de um dado bem, cuja articulação é amplamente influenciada pelas possibilidades tecnológicas, sendo as relações entre os agentes de interdependência ou complementaridade (Morvan, 1988). Desta maneira, a competitividade empresarial exige eficiência tanto interna destes agentes como inter-organizacional. Neste sentido, destaca-se que a competitividade de um dado produto no mercado depende de que os agentes participantes de sua cadeia produtiva tenham otimizado os desempenhos internos às suas organizações, associando a isto sistemas eficazes de comunicação e coordenação de atividades inter-firmas participantes da cadeia produtiva.

\footnotetext{
${ }^{2}$ Para maiores detalhes sobre o conceito de cadeia de valor proposto por Porter (1990) vide capítulo 3.
} 
Devido à evolução do conceito de cadeia de produção, percebe-se que a competitividade deve ter com base a colaboração entre os diversos atores que fazem parte de uma cadeia produtiva. Isto se dá através do estímulo de práticas menos adversariais entre os agentes econômicos de uma cadeia e entre estes e os poderes governamentais (Batalha \& Silva, 2001).

O conceito de cadeia de produção encontrou grande respaldo por parte dos pesquisadores dentro de diversos setores industriais. Dentro do setor de alimentos, especificamente, a noção sistêmica dos negócios agroindustriais obteve respaldo bastante profundo, com vários estudos do setor sendo realizados por esta ótica. Desta maneira, o tópico a seguir trata especificamente do conceito de cadeias dentro deste segmento produtivo.

\subsection{Os conceitos de Sistema Agroindustrial e Sistema Agroalimentar}

O SAI (Sistema Agroindustrial) pode ser definido como "o conjunto de atividades que concorrem para a produção de produtos agroindustriais, desde a produção de insumos (sementes, adubos, máquinas agrícolas, etc.) até a chegada do produto final (queijos, biscoitos, massas, etc.) ao consumidor" (Batalha \& Silva, 2001). A figura 2.1 apresenta os atores que compõem o SAI.

Conforme pode ser observado pela figura 2.1, além das indústrias de apoio, o SAI se compõem de empresas denominadas de alimentares e não alimentares. $\mathrm{O}$ primeiro conjunto é formado por empresas que possuem como atividade principal a geração de alimentos chamado de Sistema Agroalimentar (SAG). Já as empresas que não se destinam à fabricação de alimentos são as não alimentares tendo como exemplos a indústria têxtil, as empresas participantes da cadeia couro-calçado, a indústria de móveis, etc. Esta diferenciação se faz importante, uma vez que muitas vezes o termo agroindustrial, que é mais amplo, é utilizado de uma forma mais limitada, no sentido de agroalimentar. Este trabalho, no entanto, enfoca especificamente as questões relativas ao Sistema Agroalimentar. 
Ambiente institucional

(aparato legal, tradições, costumes)

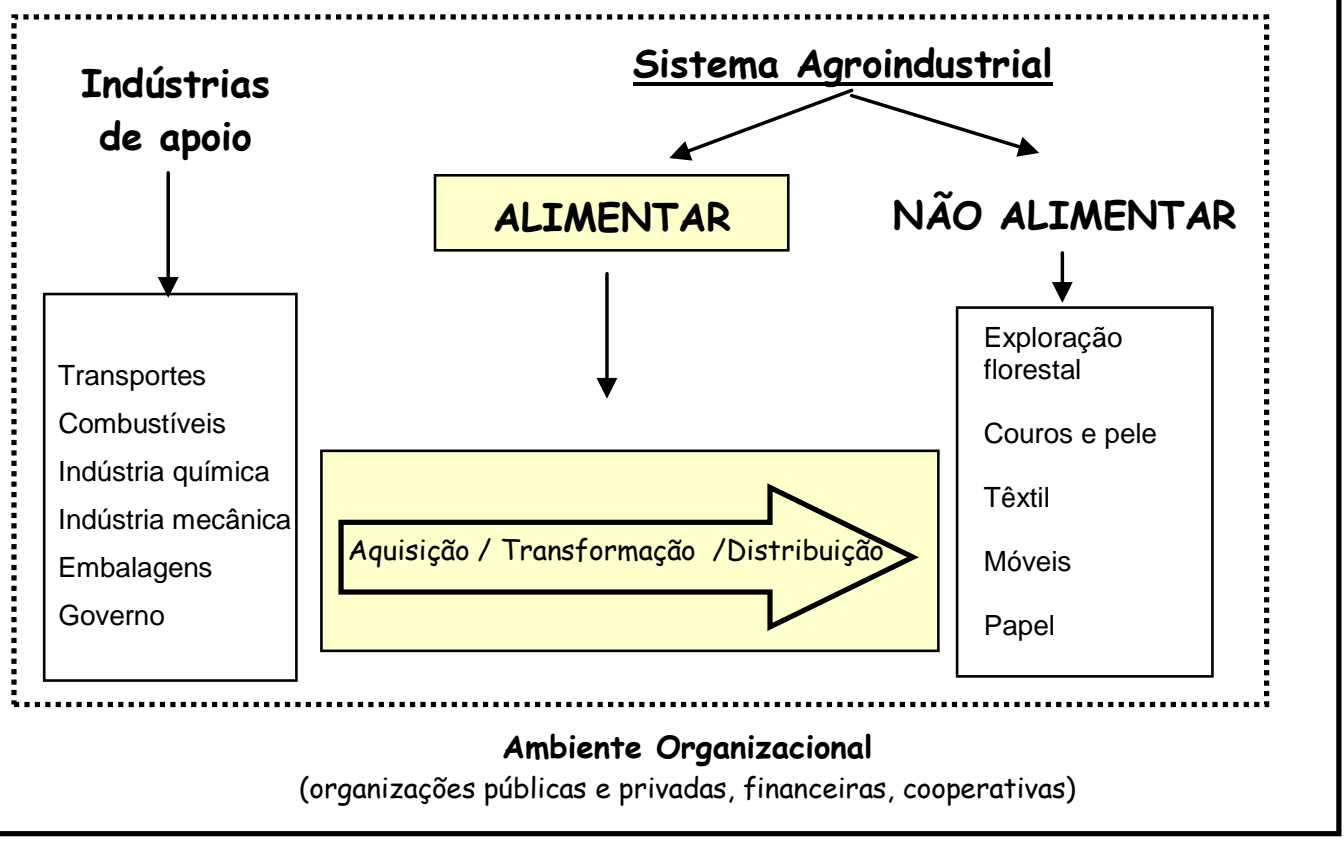

Figura 2.1: Sistema Agroindustrial - SAI (Elaborado a partir de Batalha \& Silva, 2001 e Farina e Zilberstajn, 1994).

De acordo com Batalha \& Silva (2001), os estudos das questões agroindustriais vêm sendo realizados sob a ótica de dois principais conjuntos de idéias. O primeiro deles, denominado de commodity system approach (CSA) originou-se no final da década de 50 nos Estados Unidos e tem como seus principais precursores Davis \& Goldberg (1957).

A outra corrente metodológica em questão é conhecida como cadeia de produção agroindustrial (CPA) e teve seu início na década de 60 na escola francesa, trazendo em seu bojo a noção de analyse de filière (cadeia de produção). De acordo com Zylberstjan \& Neves (2000), o conceito de filière se aplica "a seqüência de atividades que transformam uma commodity em um produto pronto para o consumidor final".

Mesmo surgidas em tempos e lugares diferentes, estas duas correntes compartilham o conceito da visão integrada entre agricultura, indústria e serviços, ou seja, os dois conceitos utilizam a idéia de sucessão de etapas produtivas, desde a produção de insumos até o produto acabado. Dentre as principais diferenças entre estas duas metodologias destaca-se o ponto de partida utilizado para a realização das 
análises de cadeias de produção. Dentre os moldes propostos pela escola francesa, esta análise parte de um produto final em direção à matéria-prima de base que o originou. Já sob o enfoque da corrente CSA, este ponto de partida se constitui na matéria-prima de base (laranja, café, leite, etc.) para o(s) produto(s) final(s).

Seja pelo enfoque CSA quanto pelo CPA, entende-se que o Sistema Agroindustrial se decompõe em inúmeras cadeias de produção, como por exemplo, as cadeias de produção da manteiga, margarina ou do requeijão. Assim, define-se Cadeia de Produção Agroindustrial como "uma sucessão de operações de transformação dissociáveis, capazes de ser separadas e ligadas entre si por um encadeamento técnico". Esta definição, no entanto, tem como ponto de partida a identificação de determinado produto final, e a partir daí se dá o encadeamento de várias operações técnicas, comerciais e logísticas para a sua produção.

Batalha \& Silva (2001) propõem que as cadeias de produção agroindustriais podem ser divididas em três macrossegmentos:

- Produção de matéria-primas: segmento relacionado à agricultura e pecuária;

- Industrialização: segmento responsável pelo processamento (transformação) de produtos;

- Comercialização: segmento relacionado exclusivamente às atividades de compra e venda de produtos.

De acordo com a divisão proposta, salienta-se que este trabalho possui seu foco específico no segmento industrial, estando preocupado em entender particularmente os fatores de competitividade específicos de empresas processadoras de alimentos.

Morvan (1988) aponta cinco principais utilizações do conceito de cadeia de produção:

- Metodologia de divisão setorial do sistema produtivo

- Formulação e análise de políticas públicas e privadas

- Ferramenta de descrição técnico-econômica

- Metodologia de análise estratégica das firmas

- Ferramenta de análise das inovações tecnológicas e apoio à tomada de decisão tecnológica. 


\subsection{A indústria de alimentos no Brasil: características gerais}

No Brasil, a indústria de alimentos é composta por um grande número de pequenas, médias e grandes plantas fabris pulverizadas por todo o território nacional. Uma característica bastante marcante desta indústria diz respeito à sua distribuição: grande parte destas pequenas e médias empresas atuam em mercados regionais e poucas grandes empresas operam em âmbito nacional, frequentemente dominando a maior fatia do mercado (Viglio, 1996, p.6).

Desta forma, a indústria alimentícia reúne entre 35 e 38 mil empresas das quais cerca de 250 são de grande porte, sendo mais de $80 \%$ do mercado formado por microempresas. O setor emprega cerca de 850 mil trabalhadores e responde por $9 \%$ do PIB, com faturamento líquido anula em torno de US\$ 54,7 bilhões, sendo o estado de São Paulo responsável por quase $40 \%$ deste faturamento. As Tabelas 2.2 e 2.3 expressam a evolução de alguns parâmetros do setor, tais como produção e exportação, nos últimos anos (ABIA, 2001).

Os laticínios são o carro-chefe da indústria alimentícia nacional, respondendo por $\mathrm{R} \$ 16,4$ bilhões do faturamento global do setor. Na sequência vêm café e cereais com $\mathrm{R} \$ 13,8$ bilhões; derivados de carne com 13,6 bi; óleos e gorduras com 10,3 bi; derivados de trigo com 9 bi; açúcar 8,3 bi; derivados de frutas e vegetais com 7,1 bi; chocolates e balas 2,4 bi; conservas e pescados 0,9 bi e outros produtos que representam $\mathrm{R} \$ 6,6$ bilhões (ABIA, 2001).

De acordo com a ABIA (Associação Brasileira da Indústria da Alimentação), as grandes empresas nacionais lançam, em média, entre 45 e 60 produtos ao ano. 
TABELA 2.2: Dados gerais da indústria brasileira de alimentos industrializados

\begin{tabular}{|c|c|c|c|c|c|c|}
\hline (Ano) & 1997 & 1998 & $1999\left(^{\star}\right)$ & $\left.19999^{(\star \star \star}\right)$ & $2000\left(^{\star \star}\right)$ & $2000\left({ }^{\star \star \star}\right)$ \\
\hline Valor da produção & 73,1 & 74,1 & 50,9 & 76,7 & 54,9 & 78,6 \\
\hline Exportação & 9,2 & 8,7 & 8,6 & 10,3 & 7,7 & 7,7 \\
\hline Importação & 2,3 & 2,1 & 1,6 & 1,3 & 1,4 & 1,3 \\
\hline Consumo aparente & 66,2 & 67,5 & 43,9 & 67,7 & 48,7 & 72,3 \\
\hline $\begin{array}{l}\text { Observações: } \\
\text { Valores expressos } \\
\left({ }^{\star}\right) \text { Conversão do do } \\
\left({ }^{\star \star}\right) \text { Conversão do dó } \\
\left({ }^{\star \star \star}\right) \text { Dólar médio } 98\end{array}$ & $\begin{array}{l}\text { m US\$ b } \\
r \text { comer } \\
r \text { comer } \\
\text { ualizad }\end{array}$ & $\begin{array}{l}\text { hões } \\
\text { ial de v } \\
\text { ial de v } \\
\text { pela ev }\end{array}$ & $\begin{array}{l}\text { da média } \\
\text { da média } \\
\text { Ição físic }\end{array}$ & $\begin{array}{l}1,81: \text { US\$ } \\
1,83: \text { US\$ } \\
\text { orodução, ex }\end{array}$ & $\begin{array}{l}00 \\
00 \\
\text { ortacão e }\end{array}$ & ação) \\
\hline
\end{tabular}

Fonte: ABIA (2001)

TABELA 2.3: Variação anual em dados gerais da indústria brasileira de alimentos

\begin{tabular}{|c|c|c|c|c|c|}
\hline Variação (ano anterior) & 1998 & $1999\left(^{*}\right)$ & $1999\left(^{(\star \star \star}\right)$ & $2000\left(^{\star \star *}\right)$ & $2000(\star \star \star)$ \\
\hline Produção & $1.37 \%$ & $-31.31 \%$ & $3.51 \%$ & $7.85 \%$ & $2.54 \%$ \\
\hline Exportação & $-5.43 \%$ & $-1.16 \%$ & $18.39 \%$ & $-11.02 \%$ & $-25.10 \%$ \\
\hline Importação & $-8.70 \%$ & $-23.81 \%$ & $-38.10 \%$ & $-11.63 \%$ & $3.00 \%$ \\
\hline Consumo aparente & $1.96 \%$ & $-34.96 \%$ & $0.30 \%$ & $10.84 \%$ & $6.75 \%$ \\
\hline \multicolumn{6}{|c|}{$\begin{array}{l}\text { Observação: } \\
\left({ }^{\star}\right) \text { Conversão do dólar comercial de venda média } R \$ 1,81: \text { US } \$ 1,00 \\
\left({ }^{\star \star}\right) \text { Conversão do dólar comercial de venda média } R \$ 1,83: \text { US } \$ 1,00\end{array}$} \\
\hline
\end{tabular}

Fonte: ABIA (2001)

Pelos dados expostos destaca-se a representatividade deste setor perante a economia brasileira. 


\section{SÍNTESE DO CAPÍTULO}

De acordo com o propósito deste capítulo, foi apresentada, sobretudo pela ótica do agronegócio, a evolução ocorrida no contexto empresarial. O panorama mundial de negócios aponta para algumas tendências importantes:

1. Aumento das exigências dos clientes

2. Aumento da concorrência mundial

3. Diversificação de produtos

4. Sistema de Produção Enxuta

5. Concentração em core competences

6. Formação de cadeias e redes de produção globais

7. Aumento na colaboração entre atores das cadeias produtivas

Essas novas tendências levam a novos fatores que definem a competitividade para as empresas. Seguindo, então, as principais características do mundo contemporâneo dos negócios, o próximo capítulo apresenta algumas considerações sobre o conceito de competitividade, bem como as principais alternativas estratégicas que podem ser utilizadas pelas empresas para alcançá-la. Além disto, são analisados os fatores de competitividade específicos para indústria alimentícia, dadas as suas particularidades com relação a outros segmentos industriais. 


\section{COMPETITIVIDADE NO AGRONEGÓCIO}

As características do cenário contemporâneo dos negócios discutidas no capítulo anterior definem novas maneiras de atuar em um mercado cada vez mais concorrido e globalizado. Desta forma, este capítulo possui o objetivo de elucidar quais os fatores definidores de competitividade nos dias atuais e de explanar as principais estratégias que podem ser utilizadas pelas empresas para se tornarem competitivas.

Para tanto, estão expostos a seguir os conceitos de competitividade empresarial, competitividade regional e, na sequência, são apresentados alguns conceitos relativos à competitividade no setor agroindustial.

\subsection{Competitividade e estratégias empresariais}

A competitividade de uma empresa pode ser entendida como a sua capacidade de ser bem-sucedida em mercados em que exista concorrência. Este conceito de competitividade se aplica às corporações, estando estritamente relacionada com o ramo de negócios de uma empresa. Desta forma, Porter (1991) propõe um método de análise do ramo de negócio em que uma empresa atua, objetivando o desenvolvimento de um estratégia empresarial de atuação.O principal instrumento deste método de análise se constitui em um modelo que representa a estrutura da concorrência existente num dado ramo de negócios através de cinco forças atuantes sobre a empresa, a saber:

$\checkmark$ Ameaça da entrada de novos concorrentes no ramo;

$\checkmark$ Ameaça de substitutos (produtos e serviços de outros ramos que possam substituir o produto ou serviço do ramo considerado);

$\checkmark$ Poder de negociação dos compradores;

$\checkmark$ Poder de negociação dos fornecedores;

$\checkmark$ Rivalidade entre as empresas existentes. 
De acordo com o modelo de Porter (1991), alcançar competitividade significa adquirir um equilíbrio entre as forças externas que influenciam um negócio. Assim uma empresa deveria se preparar para a ameaça da entrada de novas empresas no mercado, seja com os mesmos produtos ou com produtos substitutos; assegurar sua participação no mercado através da superação da rivalidade imposta por empresas concorrentes; e minimizar o impacto resultantes do poder de negociação de seus fornecedores e consumidores.

O conceito de estratégia competitiva aqui se insere como as possíveis maneiras que uma empresa possui para enfrentar com sucesso as cinco forças da concorrência. Skinner (1969) define estratégia como um conjunto de planos e políticas para os quais uma empresa aponta para adquirir vantagens em relação aos seus concorrentes. Cabe salientar o conceito de vantagem competitiva. De acordo com Porter (1990) esta seria relativa a uma posição sustentável de uma empresa para enfrentar as forças da concorrência num ramo específico de negócios, possibilitando a superação dos rivais em termos de rentabilidade a longo prazo.

Desta maneira, Porter (1991) destaca três estratégicas genéricas que podem ser adotadas para este fim, sendo que cada uma delas enfoca em uma vantagem competitiva básica, a saber:

- Liderança de custos: empresa pratica os mais baixos preços por seus produtos e serviços;

- Diferenciação: atuação com produtos cujos atributos que realmente atendem às necessidades dos consumidores. Por esta diferenciação, a empresa pode atribuir valor econômico superior aos seus produtos e serviços para a cobertura dos custos adicionais associados à diferenciação e retorno do investimento;

- Enfoque: adaptação da empresa para atendimento de um segmento específico do mercado ("nicho de mercado"). Aqui, novamente, a empresa terá duas opções: competir no custo ou pela diferenciação, porém, apenas no segmento escolhido.

Cada uma destas estratégias genéricas apresenta uma determinada relação entre rentabilidade e fatia de mercado. Esta relação, apresentada na Figura 3.1, mostra que uma boa rentabilidade de um dado negócio é alcançada por empresas que atuam em 
uma pequena parcela do mercado e, no entanto, possuem investimentos com diferenciação dos seus produtos e serviços. Além disto, empresas detentoras de grande fatia do mercado possuiriam a vantagem de liderança nos custos. De acordo com o modelo baseado na curva $\mathrm{U}$, empresas situadas no meio-termo teriam baixa rentabilidade, sendo burocratizadas demais para produzir produtos 'sob medida' e sem escala para liderarem através dos custos.

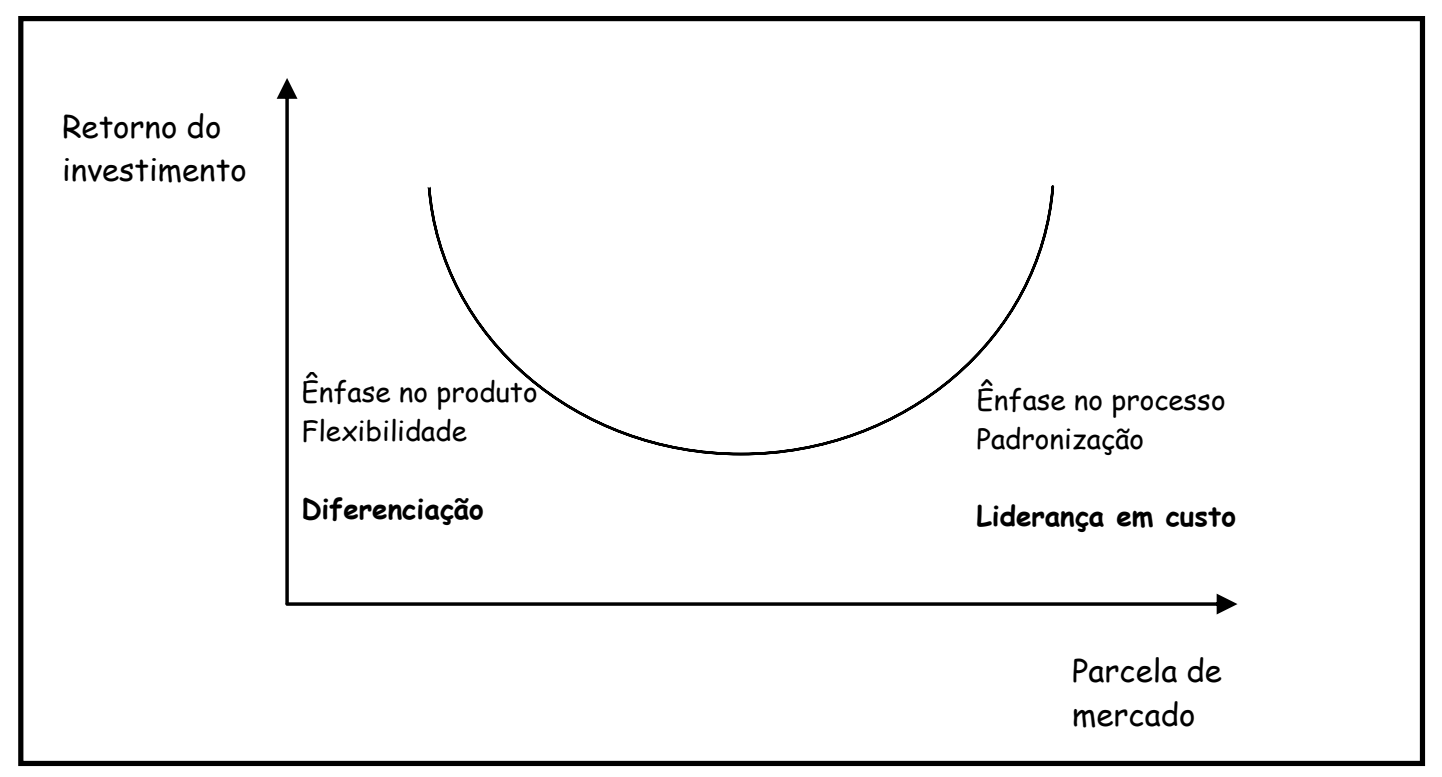

Figura 3.1: Curva "U” e estratégias competitivas genéricas (adaptado de Porter, 1991, p. 57).

A sustentabilidade das estratégias genéricas exige que a vantagem competitiva de uma empresa resista à erosão pelo comportamento da concorrência ou pela evolução da indústria, sendo que a adoção de uma dada estratégia genérica envolve diferentes riscos, conforme visualizado na Tabela 3.1.

Ressalta-se, porém, que com o objetivo de minimizar os riscos inerentes às estratégias genéricas, as empresas podem adotar estratégicas específicas, que levam em consideração, entre outros fatores, o seu porte e as características da indústria a que pertencem. 
TABELA 3.1: Riscos associados às estratégias genéricas.

\begin{tabular}{|c|c|c|}
\hline $\begin{array}{c}\text { RISCOS DA LIDERANÇA NO } \\
\text { CUSTO }\end{array}$ & RISCO DA DIFERENCIAÇÃO & RISCO DO ENFOQUE \\
\hline $\begin{array}{l}\text { Não é sustentada } \\
\text { Proximidade na diferenciação é } \\
\text { perdida } \\
\text { Enfocadores no custo obtêm } \\
\text { custo ainda mais baixo em } \\
\text { segmentos }\end{array}$ & $\begin{array}{l}\text { Não é sustentada } \\
\text { Proximidade do custo perdida } \\
\text { Enfocadores na diferenciação } \\
\text { obtêm diferenciação ainda } \\
\text { maior em segmentos }\end{array}$ & $\begin{array}{l}\text { É imitável } \\
\text { Concorrentes com alvos amplos } \\
\text { dominam o segmento } \\
\text { Novos enfocadores subsegmentam a } \\
\text { indústria }\end{array}$ \\
\hline
\end{tabular}

Fonte: adaptado de Porter (1990), p.18.

Porter (1990) afirma que a aquisição e sustentação da vantagem competitiva pela adoção de uma determinada estratégia genérica devem ser intensificadas pela análise de sua cadeia de valores (Figura 3.2). Segundo o autor, a cadeia de valores se constitui na representação detalhada e sistemática das atividades de uma empresa, ajudando, assim, na identificação da contribuição de cada atividade para o valor que os clientes atribuem a um dado produto.

Desse modo, o escopo das atividades de uma empresa (escopo competitivo), pode ter uma função poderosa na vantagem competitiva por sua influência nesta cadeia. Um escopo estreito (enfoque) cria vantagem competitiva pelo ajuste da cadeia de valores, enquanto que um escopo mais amplo pode intensificar a vantagem competitiva pela exploração das inter-relações entre cadeias de valores de diferentes segmentos.

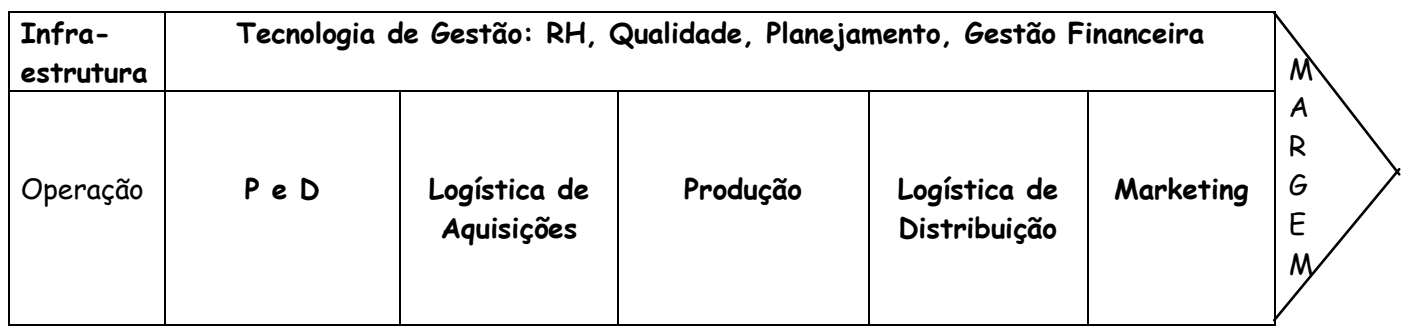

Figura 3.2: Cadeia de valor genérica em negócios industriais (Porter, 1990).

A observação do comportamento das empresas no mercado ao longo do tempo possibilita a verificação das exigências deste mercado. Nos anos 60, por exemplo, o fator definido por esta exigência seria o custo relativo a produtos e serviços. Nos 
anos 70, este fator muda para a qualidade. Já nos anos 80, o critério a ser atendido para assegurar a competitividade de uma empresa se define pela variedade oferecida em uma linha de produtos. Por fim, os anos 90 vêem surgir a solicitação pela unicidade e singularidade dos produtos/serviços oferecidos (Brunstein, 1995).

Cada um destas exigências requer um comportamento específico por parte de uma empresa para que possa ser atendida. A Tabela 3.2 relaciona os conceitos de exigências do mercado e critérios de desempenho requeridos (fatores definidores de competitividade).

TABELA 3.2: Relação entre o mercado e o desempenho no tempo

\begin{tabular}{|c|c|c|}
\hline Exigência do mercado & Década & Critério de desempenho \\
\hline Preço & 60 & Custo \\
Qualidade & 70 & Qualidade \\
Variedade da linha de produtos & 80 & Flexibilidade \\
Unicidade/Singularidade & 90 & Inovação \\
\hline
\end{tabular}

Fonte: Brunstein (1995).

Destaca-se, porém, a importância do fator tempo nesta era de lean production. A pontualidade no prazo das entregas bem como a confiabilidade das mesmas se apresenta como mais um fator exigido pelo mercado. Desta maneira, acrescenta-se a esta tabela o chamado desempenho nas entregas como mais um critério de desempenho dos dias atuais.

Vale salientar que o surgimento de cada uma das exigências demandadas pelo mercado não exclui as exigências anteriores, havendo a soma das mesmas, num exercício de complementaridade. A exigência do mercado por produtos e serviços de qualidade, por exemplo, não pára de existir pelo fato do mercado passar a demandar também variedade nas linhas de produtos.

\subsection{O conceito de competitividade regional}

O conceito de região aqui empregado se refere a porções territoriais que possuem alguma característica em comum, podendo definir tanto um estado como um município, um bairro ou até mesmo uma rua. Albert \& Muñoz (1996) definem 
território como um espaço caracterizado tanto por aspectos espaciais quanto por características culturais e afetivas, numa tríplice dimensão: geográfica, histórica e cultural.

Para Farina \& Zylbersztajn (1998) a competitividade não possui uma definição precisa uma vez que este conceito possui em seu bojo várias facetas de uma mesma questão. Para os autores:

“(...) do ponto de vista das teorias da concorrência, a competitividade pode ser definida como a capacidade de sobreviver e, de preferência, crescer em mercados correntes ou novos mercados. Decorre dessa definição que a competitividade é a medida de desempenho das firmas individuais. No entanto, esse desempenho depende de relações sistêmicas, já que as estratégias empresariais podem ser obstadas por gargalos de coordenação vertical ou de logística". (Farina e Zylbersztajn, 1998, p. 10).

Por este caráter sistêmico, o conceito de competitividade pode ser estendido para uma dada região ou nação. Segundo o IAD (Instituto Alemão para o Desenvolvimento) apud Casarotto \& Pires (1999), o conceito de competitividade regional envolveria, além das empresas locais, governos e instituições, sendo criada por quatro fatores, conforme demonstrado na Figura 3.3.

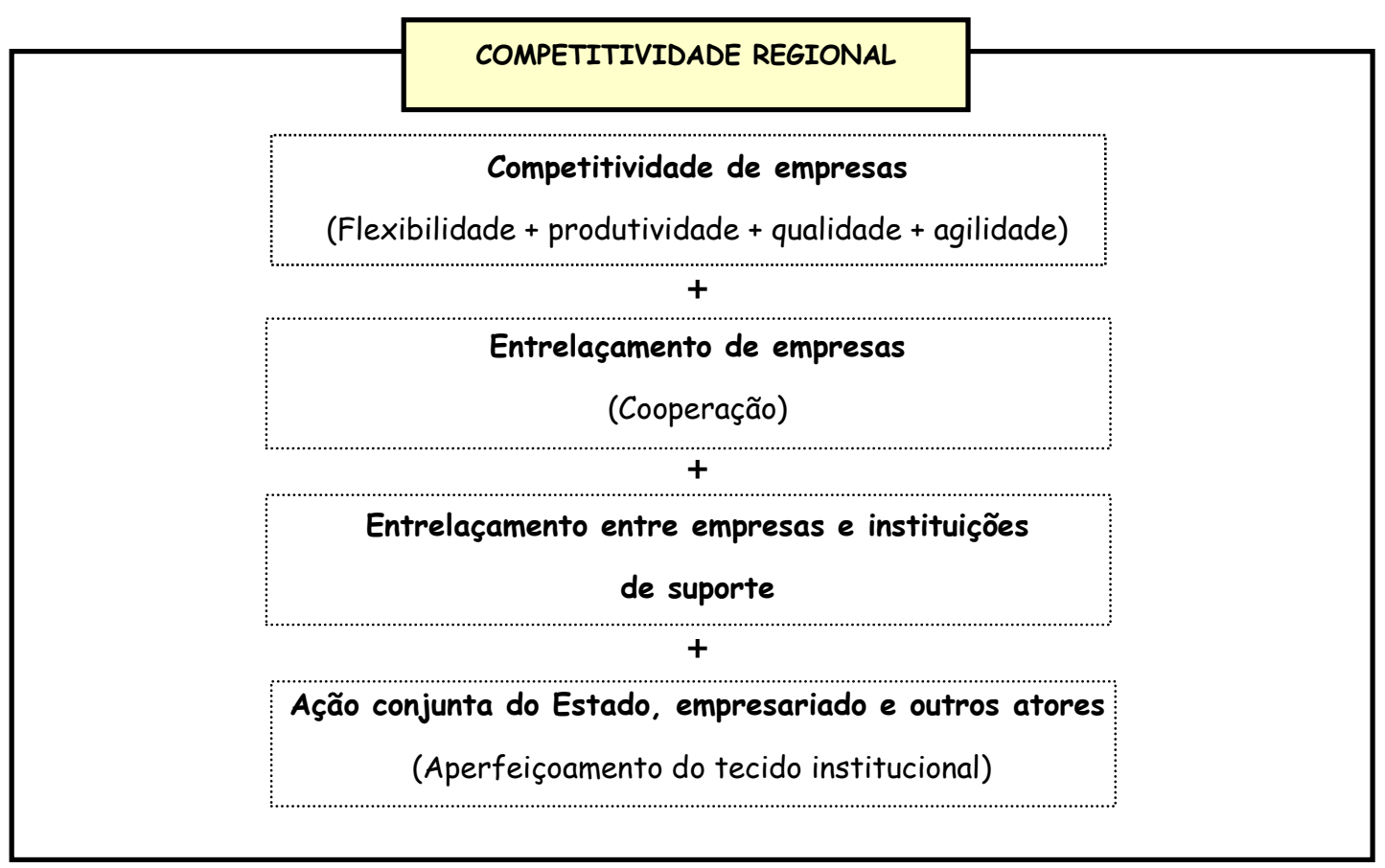

Figura 3.3: Competitividade segundo visão do IAD (Fonte: Casarotto Filho \& Pires, 1999, p.36). 
Porter (1993), estimulado pelo interesse despertado pelo desempenho de empresas de sucesso em determinadas nações, reforça este raciocínio de competitividade regional ao argumentar que as condições de competitividade encontram-se localizadas dentro de um país, em diferentes pontos (regiões), para diferentes atividades.

Para ilustrar este conceito, o autor utiliza o esquema chamado de "diamante" (Figura 3.4). Este esquema prevê a existência de quatro critérios que seriam determinantes da competitividade de uma nação ou região. O sistema determinado pelo esquema do diamante se caracteriza por ser mutuamente fortalecedor, sendo que o efeito de um determinante depende dos estados dos outros. A Tabela 3.3 analisa cada um destes determinantes.

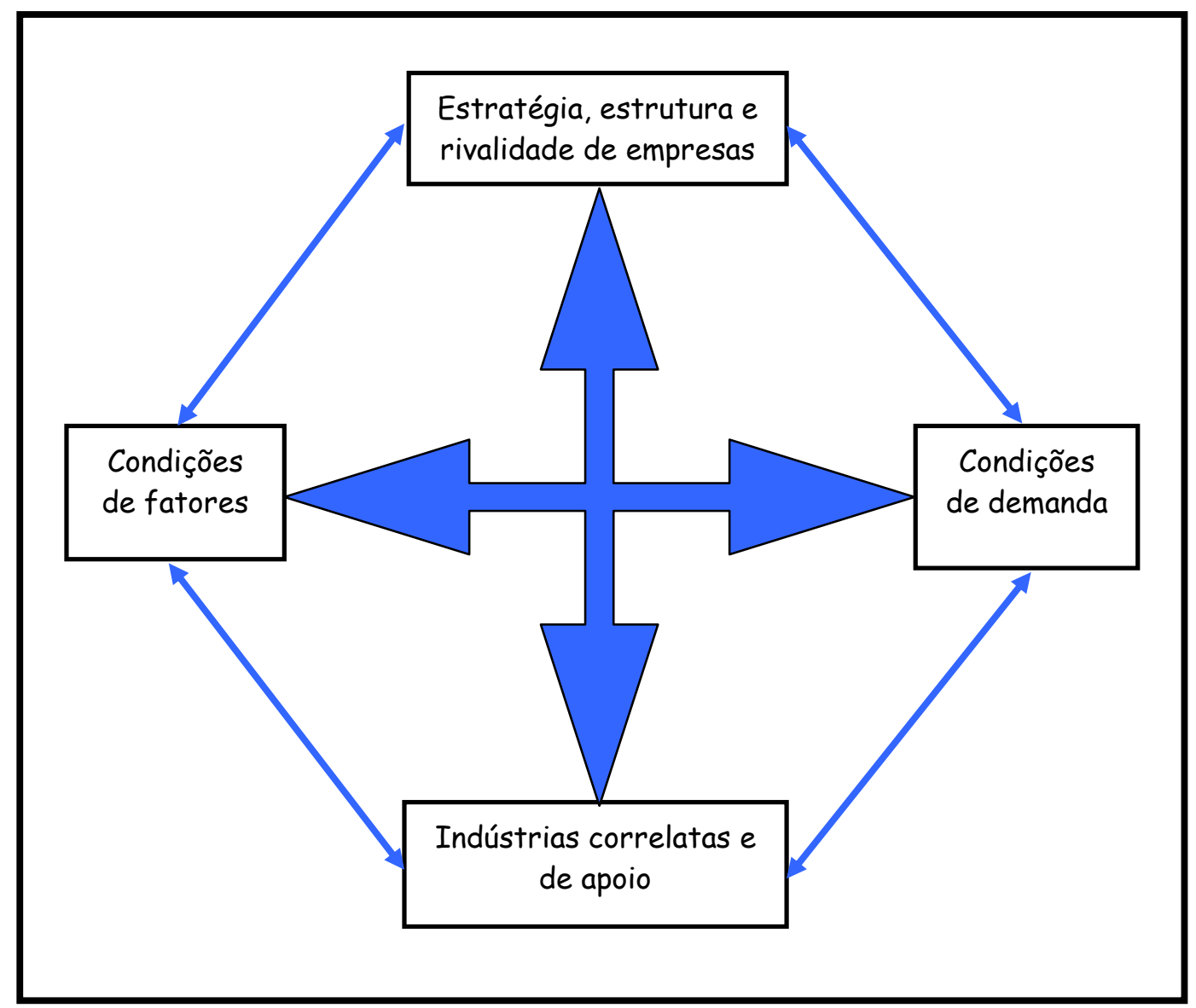

Figura 3.4: Determinantes da vantagem nacional (Porter, 1993). 
TABELA 3.3: Descrição dos determinantes do "diamante" de Porter.

\begin{tabular}{|l|l|}
\hline \multicolumn{1}{|c|}{ Determinantes } & \multicolumn{1}{|c|}{ Descrição } \\
\hline Condições de fatores & $\begin{array}{l}\text { Posição da região nos fatores de produção, como trabalho } \\
\text { especializado e infra-estrutura, necessários à competição em } \\
\text { determinada indústria. }\end{array}$ \\
\hline Condições de demanda & $\begin{array}{l}\text { Natureza da demanda interna para os produtos/serviços da } \\
\text { indústria. }\end{array}$ \\
\hline $\begin{array}{l}\text { Indústrias correlatas e de } \\
\text { apoio }\end{array}$ & $\begin{array}{l}\text { Presença/ausência de indústrias abastecedoras e correlatas } \\
\text { internacionalmente competitivas. }\end{array}$ \\
\hline $\begin{array}{l}\text { Estratégia, estrutura e e } \\
\text { rivalidade de empresas }\end{array}$ & $\begin{array}{l}\text { Condições que norteiam a maneira pela qual as empresas são } \\
\text { criadas, organizadas e dirigidas em face à natureza da } \\
\text { rivalidadade interna. }\end{array}$ \\
\hline
\end{tabular}

Pelo conceito apresentado pelo IAD, a competitividade regional está representada por conceitos fortemente calcados na sinergia existente entre as empresas de um dado território e entre elas e seu tecido institucional. É bem verdade que a sinergia entre estas entidades presentes em um local são fundamentais para a promoção e crescimento de uma região. Porém, as questões relativas à estrutura e à infra-estrutura do local devem ser consideradas. Estas questões, por sua vez, se apresentam como uma preocupação primordial para a visão de Porter (1993). Como visto pela definição do autor anteriormente apresentada, as condições estruturais e infra-estruturais da região, tais como a presença de empresas de suporte e aspectos relativos às estratégias adotadas pelas empresas, apresentam-se como foco principal de preocupação no modelo do autor.

Desta maneira, entende-se que estas visões são complementares. A Figura 3.5 representa esta integração de conceitos e se revela como um modelo mais abrangente para a realização da análise da competitividade regional. 


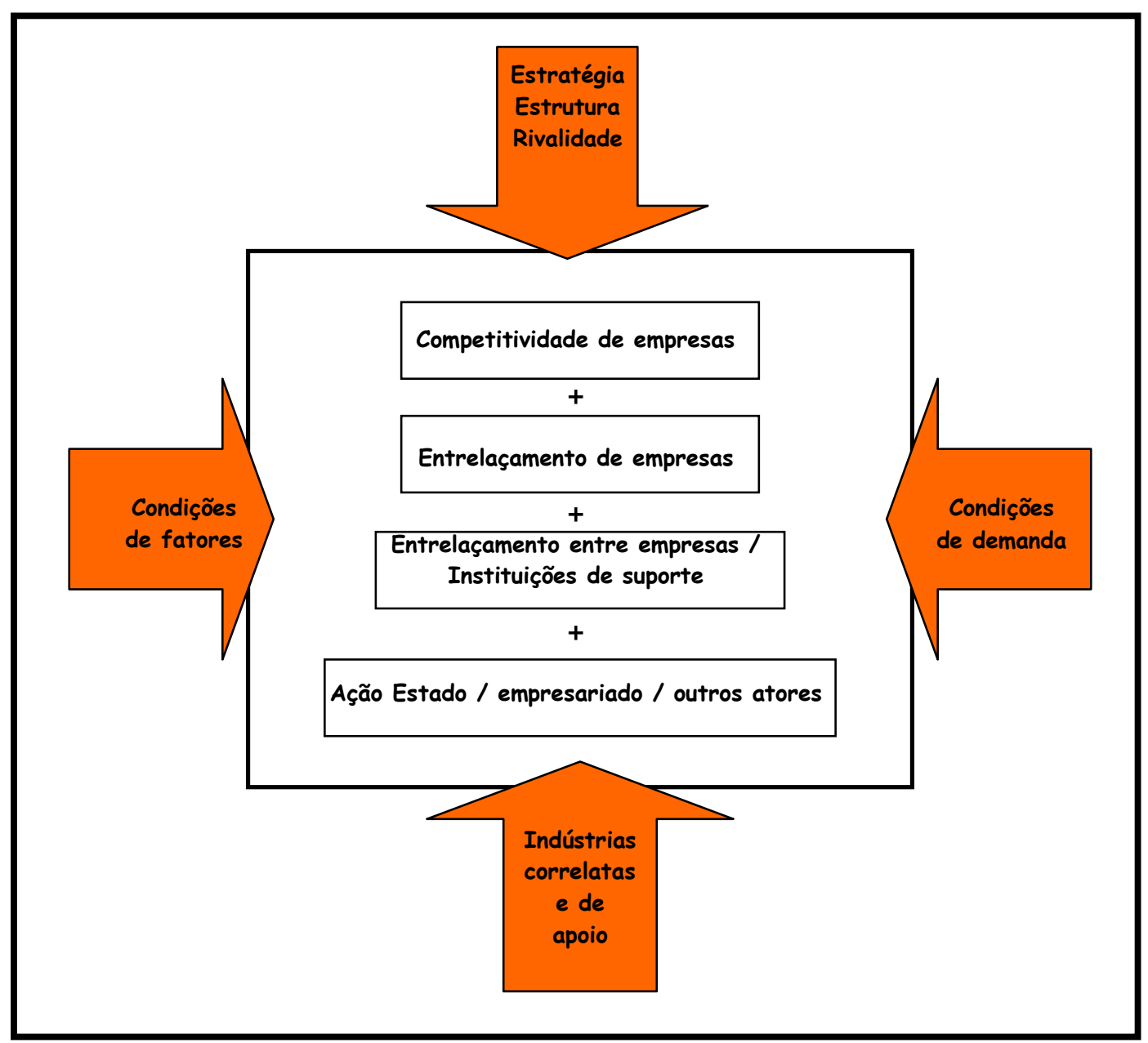

Figura 3.5: Modelo para análise da competitividade regional

Neste contexto de competitividade regional, Kielson (1994) propõe novos paradigmas competitivos que reforçam e suportam a força da região como possível base de operações do processo de globalização (Tabela 3.4). 
TABELA 3.4: Evolução dos paradigmas competitivos.

\begin{tabular}{|l|l|l|}
\hline \multirow{4}{*}{ Crenças } & \multicolumn{1}{|c|}{ Velho Paradigma } & \multicolumn{1}{|c|}{ Novo Paradigma } \\
\cline { 2 - 3 } & Os outros são meus inimigos & Os outros são meu benchmark \\
\cline { 2 - 4 } & O nome do jogo é ganhar & $\begin{array}{l}\text { O meu jogo é desenvolvimento } \\
\text { contínuo }\end{array}$ \\
\cline { 2 - 3 } & Eu sou melhor que eles & Eu sou importante \\
\cline { 2 - 3 } & Eu estou separado dos outros & Eu sou parte da comunidade \\
\hline Comportamento & Segregação & Envolvimento, cooperação \\
\cline { 2 - 3 } & Intimidação, beligerância & Apreciação, apoio \\
\cline { 2 - 3 } & Manipulação, exploração & Iniciativa, positivismo \\
\cline { 2 - 3 } & Seriedade com medo & Seriedade com humor \\
\cline { 2 - 3 } & Energia altamente focalizada & Energia altamente focalizada \\
\hline
\end{tabular}

Fonte: Kielson (1994).

Nota-se, então, não só a importância da competitividade de cada uma das empresas que se insere em uma dada região, mas também a relevância do ambiente externo às empresas (ambiente institucional) para a definição da competitividade do conjunto. Assim, a região pode ser considerada como a base de operações para o processo de globalização e sua competitividade depende dos atrativos que são oferecidos bem como dos incentivos existentes no ambiente.

Neste sentido, insere-se aqui a importância do direcionamento de políticas públicas no sentido da promoção de uma determinada região. Além disso, é importante ressaltar que as articulações de dadas características de uma região dependem de fatores específicos da localidade, como a capacidade de articulação e dos recursos do empreendimento produtivo, a conjuntura na qual este sistema está inserido (ambiente institucional), as regras formais e informais, o grau de pressão dos grupos sociais, o posicionamento dos consumidores, entre outros. Neste conjunto de relações de poder (chamadas de "redes de poder territoriais") o empreendimento produtivo se constitui em mais um ator, e suas decisões serão por este conjunto determinadas. 
Como maneira de melhor elucidar os conceitos de políticas públicas e de redes de poder territoriais, os dois próximos tópicos tratam especificamente destes assuntos.

\subsubsection{O papel das políticas públicas na competitividade regional}

Define-se como ambiente institucional o conjunto de atores de um dado território (indústrias, agricultores, prestadores de serviço, comerciantes, agências públicas do Estado, prefeitura municipal, associações de representação de interesses, sindicatos, universidades, centros de pesquisa e demais grupos) bem como as regras e normas que regem este conjunto.

Estas regras e normas podem ser tanto formais quanto informais, sendo que as chamadas políticas públicas representam a formalidade dessas regras. Desta maneira, as políticas públicas representam um importante papel para a competitividade, seja ela relativa a uma empresa ou a uma região como um todo.

Devido ao foco deste trabalho ser especificamente o setor industrial, enfoque maior é dado sobre as políticas industriais e tecnológicas. Amato Neto (1999) define:

\footnotetext{
"As políticas industriais e tecnológicas envolvem o estabelecimento de "projetos prioritários, através da adoção de medidas legais, administrativas e institucionais, constituindo-se em um poderoso instrumento para orientar a estrutura e a dinâmica da indústria, segundo paradigmas e trajetórias tecnológicas determinadas (...). Referem-se a um conjunto de ações públicas orientadas a direcionar e controlar o processo de transformação estrutural de uma economia".
}

O mesmo autor ressalta a definição de Casarotto (1998) sobre políticas industriais locais, destacando a delimitação da região na formulação de políticas direcionadas às necessidades específicas de cada localidade.

As principais políticas industriais no Brasil encontram-se resumidas na Tabela $3 . .^{1}$

\footnotetext{
${ }^{1}$ Para maiores informações sobre políticas industriais no Brasil vide Amato Neto (1999).
} 
TABELA 3.5: Evolução geral das políticas industriais brasileiras ao longo do tempo.

\begin{tabular}{|l|l|}
\hline \multicolumn{1}{|c|}{ Década } & \multicolumn{1}{c|}{ Política } \\
\hline $50 / 60$ & Modelo de substituição de importações \\
\hline 70 ("milagre econômico") & Planos de Desenvolvimento Econômico (PDE) \\
\hline 80 ("década perdida") & Ausência de política industrial \\
\hline 90 & Política de Integração Competitiva \\
\hline
\end{tabular}

Fonte: elaborada a partir de texto contido em Amato Neto (1999).

\subsubsection{Competitividade regional e redes de poder territoriais (policy networks)}

A existência de setores produtivos regionalizados, marcados pela concentração geográfica de empresas e instituições com algum tipo de sinergia, propicia a configuração das chamadas redes de poder localizadas. Nesta delimitação territorial atuam diversos agentes: industriais, agricultores, prestadores de serviços, comerciantes, agencias públicas do Estado, prefeituras municipais, associações de representação de interesses, sindicatos e demais grupos de interesse, e estes atores se posicionam nesta configuração organizacional, guiados por suas expectativas econômicas e pela cultura e ambiente institucional presentes naquele território.

Nesta perspectiva, estes arranjos, denominados 'redes de poder' (Paulillo, 2000), são marcados por processos de interação estratégica entre os agentes públicos, representados pelo Estado e suas agências, e os agentes privados (individuais ou coletivos). Através destas redes assentadas territorialmente, é possível estabelecer estratégias específicas buscando vantagens competitivas, intensificação das relações entre os atores e mobilização e cooperação local, bem como fomento às estruturas de governança direcionadas às novas oportunidades localizadas no território.

De acordo com Paulillo (2000), as redes de poder constituem uma abordagem de nível "meso" e, portanto, o território e a articulação das organizações localizadas nele atuam como componentes relevantes e são estas articulações, as responsáveis pelo modo de regulação, formulação e implementação das políticas setoriais para a região.

Através do processo de interação estratégica articulada a partir das redes de poder territoriais, novos padrões de planejamento regional podem emergir, trazendo 
como vantagens a possibilidade de se descentralizar ações e a inclusão da participação de agentes locais marginalizados que, neste novo ambiente institucional, podem otimizar o desenvolvimento de potencialidades regionais.

Assim, a rede de poder que se forma nos limites do território está assentada em um conjunto de regras e normas (formais ou informais) chamado de ambiente institucional, mas os atores que a compõem possuem um conjunto de interesses próprios, seus recursos de poder e inclinação à ações oportunistas, movimentando-se estrategicamente neste arranjo: os atores buscam recursos de poder que lhes permitam coordenar estes arranjos de forma mais conveniente para eles, configurando, nestes casos, uma rede pouco estável e pouco integrada.

Entende-se como recursos de poder o controle que cada ator tem sobre os recursos constitucionais, jurídicos, políticos, financeiros, organizacionais, tecnológicos e de informação e sobre as normas locais aliado a atribuição do status público e da confiança dos outros atores (Rhodes, 1990). O grau de controle sobre estes recursos confere aos atores, em maior ou menor grau, poder para manipular as situações segundo seus interesses, sub julgando, de certa forma, os demais atores em favor próprio. O grau de assimetria de poder entre os atores atuantes no território, portanto, permite avaliar as formas de inclusão ou exclusão da rede.

Mediante este raciocínio, uma rede de poder territorial pode se estruturar com um caráter excludente, seja com relação a alguns atores produtivos marginais, seja com relação a fornecedores ou trabalhadores, configurando uma distorção estrutural nesta rede. As redes de poder, portanto, tendem a ter mais robustez de acordo com a maior homogeneidade do perfil dos atores e da distribuição dos recursos de poder.

O grau de agregação em que se identifica uma interação estratégica é igualmente importante uma vez que ele ajuda a revelar o tipo de rede de poder do qual se está tratando. Rhodes (1990), destaca dois tipos de redes: as difusas (ou temáticas) e as redes políticas. As redes difusas são assim denominadas porque estão em formação, não apresentando representações coletivas definidas e os interesses compartilhados referem-se a um assunto particular. As principais características destas redes seriam a instabilidade e a falta de continuidade das relações. A instabilidade das relações deve-se as normas não formalizadas, que mudam a cada momento conforme a necessidade ou a pressão dos atores. 
Já as chamadas redes políticas, se caracterizam pela existência de um processo de consenso de interesses em que a interação estratégica é freqüente e estável, a interdependência é elevada e a participação dos atores coletivos é especializada e limitada (Paulillo, 2000). Estas redes são formadas por laços institucionais amadurecidos nos quais as relações interpessoais não são preponderantes. Segundo Rhodes (1990) as principais características destas redes são a estabilidade, a continuidade das relações de poder e a elevada restrição à participação de grupos e associações que poderiam desestruturar a rede.

Este conceito de redes de poder territoriais ressalta a relevância do mapeamento dos atores de uma região em estudo e de suas relações com o poder local, uma vez que as ações que serão praticadas em um ambiente também serão determinadas por este conjunto.

\subsection{Competitividade regional e a produção de alimentos}

Conforme discutido no capítulo 2, dentre os aspectos mais decisivos do pósfordismo global estão o aumento da flexibilidade em escala mundial, a mobilidade de capitais e liberdade para colonizar e mercantilizar praticamente todas as esferas, destruindo-se as fronteiras sociais e espaciais fixas, gerando uma descentralização da produção (Bonanno, 1999).

A análise da produção de alimentos, entretanto, mostra que este segmento possui particularidades que lhe torna dependente do local. Apesar dos avanços alcançados em áreas como logísticas e transportes, a produção possui sua mobilidade espacial relativamente limitada, uma vez que as empresas agroindustriais são dependentes da agricultura e esta é "fixa" e intimamente relacionada com o ambiente e a sociedade local.

Apesar disto, as mudanças ocorridas nas relações globais, fruto da passagem para o Segundo Regime Alimentar e do modelo de acumulação de capital pósfordista, trouxeram influências para agroindústria e para grupos sociais locais a ela relacionados. A adaptação às novas tendências globais leva a mudanças que naturalmente são sentidas no "local", como a busca de articulações de determinadas características de uma dada região visando auferir à localidade uma posição 
competitiva frente ao mercado global. Um exemplo disto se constitui na criação de selos de origem para os produtos processados em dada região como forma de diferenciação.

Ainda sob o prisma dos aspectos relevantes do pós-fordismo, estão os conceitos de diversificação de produtos e do aumento das exigências dos clientes. Neste ponto é relevante o papel da inovação para a busca de produtos que de fato atendam as necessidades do consumidor.

Um outro aspecto bastante particular da produção de alimentos diz respeito à sua necessidade de pontos-de-venda para apresentar seus produtos ao consumidor, tornando elevada a sua dependência de firmas que revendam seus produtos. Neste sentido, o acesso aos chamados canais de distribuição se torna, na maioria dos casos, um componente importante para a competitividade.

Desta maneira, os próximos dois tópicos discutem alguns fatores competitivos que podem ser associados à produção de alimentos: os selos de origem, que podem ser utilizados como fonte de vantagem competitiva de uma dada localidade e os fatores inovação e canais de distribuição, que, embora não associados exclusivamente à região, quando bem articulados podem representar aspectos positivos às empresas nela localizadas.

\subsubsection{Diferenciação: os selos de origem}

A inclusão de atributos que sejam valorizados pelo consumidor se constitui em uma forma de agregar valor a um produto, diferenciando-o dos seus similares. Desta maneira, os chamados produtos típicos se apresentam como uma forma de diferenciação, uma vez que associam ao produto características de qualidade que se relacionam com a região da qual provêm (Barzel, 1982; Becattini, 1994; Porter, 1998). Além disso, a situação atual se mostra mercadologicamente favorável aos produtos típicos, dado o crescimento da preocupação com a procedência dos alimentos demonstrada pelos consumidores, mídia e autoridades sanitárias.

Para ser considerado típico, um produto deve estar relacionado espacial e culturalmente a um território, com ligações sólidas e existentes a algum tempo. Além disso, o produto deve possuir características particulares que o diferencie de seus 
similares (Albert \& Muñoz, 1996). Um produto típico, que pode ser de origem agrícola ou pecuária, articula três conceitos básicos: diferenciação, qualidade e território.

Com relação à diferenciação, no caso de produtos in natura ela pode estar ligada, por exemplo, à forma de cultivo e a características do solo ou do clima. Já no caso dos produtos processados (transformados), a diferenciação está ligada ao método de elaboração, mesmo que a matéria-prima seja proveniente de outro local ou região. A diferenciação pode também estar associada à uma inovação de embalagem, de método de fabricação, de preço, entre outros e esta diferenciação deve ser acompanhada de uma estratégia de comunicação e de divulgação junto ao consumidor, como forma de facilitar sua percepção e valorização (Porter, 1991).

Outro conceito relacionado a produtos típicos é a qualidade. A literatura apresenta várias definições para qualidade. Porém, a noção de qualidade quando aplicada a produtos alimentares apresenta outras especificidades uma vez que estes apresentam algumas características que os diferem de outros produtos, tal como o seu caráter perecível. Desta maneira, a qualidade de um produto alimentar pela ótica do consumidor se define como a síntese de várias qualidades: qualidade nutricional, qualidade organoléptica, qualidade de uso, qualidade regulamentar e qualidade sanitária (Rodrigues \& Vieira, 2000).

Desta forma, torna-se vantajoso o destaque desta diferenciação associada aos produtos típicos para o consumidor. Porém, por se tratar de um bem de crença, a inspeção direta do produto não é suficiente para a percepção de atributos desejáveis. Para tanto, o uso de selos ou certificados pode ser visto como um eficiente mecanismo para garantir o destaque à diferenciação. Atribuída por organismos idôneos e independentes, a certificação se destaca por conferir garantias de que um dado produto encontra-se de acordo com normas e atributos pré-estabelecidos.

Nassar (1999) destaca a existência e diversas opções de selos para produtos alimentícios, dependendo do que se quer atestar: padrão de processo, selo de sanidade, selo de pureza, selo de produto orgânico, certificação interna de qualidade, entre outros. Porém, no caso de produtos típicos, um maior destaque é dado ao chamado selo de denominação de origem. A Tabela 3.6 ilustra alguns exemplos de certificados de denominação de origem adotados por países da Europa e no Brasil. 
TABELA 3.6: Exemplos de sistemas de certificação de produtos agrícolas e alimentícios adotados na Europa e no Brasil.

\begin{tabular}{|c|c|}
\hline Selo & País \\
\hline AOC: apellation d'origine contrôlée & França \\
\hline DOP: denominação de origem protegida & União Européia \\
\hline IGP: indicação geográfica definida & União Européia \\
\hline CACCER (Café do Cerrado) & Brasil \\
\hline "Cachaça de Minas" & Brasil \\
\hline
\end{tabular}

Fonte: elaborada a partir de Lagrange (1995) e Bèrard \& Marchenay (1996).

Ressalta-se, porém, que a União Européia, onde os produtos típicos possuem bastante destaque, conta com um sistema de certificação bastante sério e organizado. Já no caso brasileiro, não existem normas sobre o assunto e o monitoramento fica restrito a associações locais. Não há amparo de legislação federal para a definição dos direitos de propriedade e para apoio da regulamentação do uso da denominação.

Mediante a infinidade de produtos típicos presentes no Brasil, fica evidente o enorme potencial existente para a exploração deste segmento. Porém, para que os produtos típicos sejam viáveis comercialmente, há a necessidade de mecanismos de certificação que garantam ao consumidor a seriedade dos atributos anunciados. Assim, destaca-se a necessidade de organismos, tanto públicos como privados, de coordenação de projetos neste sentido.

\subsubsection{Inovação}

Porter (1993) enfatiza o aspecto dinâmico da competição, caracterizando-a pela inovação e pela mudança. Desta maneira, a inserção em um mercado cada vez mais competitivo leva à necessidade do aumento do conhecimento científico e tecnológico nos bens e serviços, representando um desafio para as empresas e localidades.

Esta capacitação científica e tecnológica se transforma, então, em uma précondição para o sucesso produtivo e comercial, onde a inovação representa o motor central no desenvolvimento econômico. 
Com a integração crescente dos mercados, a competição baseada em recursos naturais, baixos salários e preços paulatinamente cede lugar à competição baseada em capacidade inovativa e alta qualificação, com o conhecimento ocupando lugar estratégico, traduzindo-se em boa qualidade e diferenciação dos produtos (Lopes \& Lugones, 1999).

A intensidade e a frequência das inovações dependem do setor em que uma empresa atua. No caso particular da indústria alimentícia, a inovação se torna importante uma vez que a segmentação dos mercados e a diferenciação de produtos passam a fazer parte do contexto dos negócios agroalimentares a partir da transição para o Segundo Regime Alimentar².

Humphrey \& Shimitz (2000) dividem os avanços provenientes do processo de inovação em três categorias:

* Aperfeiçoamento em processos [process upgrading]: transformação de “entradas" em "saídas" de uma maneira mais eficiente pela reorganização dos sistemas produtivos ou pela introdução de uma tecnologia superior;

* Aperfeiçoamento em produtos [product upgrading]: produção de linhas de produtos mais sofisticados (diferenciação de produtos e/ou aumento de seu valor agregado);

* Aperfeiçoamentos funcionais [functional upgrading]: através do desempenho de novas funções da cadeia de valor.

Os autores salientam que enquanto os avanços em processos envolvem o conceito de fazer as mesmas coisas de maneira mais eficiente, os avanços em produtos e em funções podem levar a empresa a um reposicionamento no mercado através da oferta de novos produtos ou pelo desempenho de novas funções da cadeia de valor.

Ressalta-se, ainda, que a inovação pode também se relacionar ao processo de gestão de uma empresa, através de avanços alcançados nas formas de organização e de gerenciamento da mesma. Exemplo disto seria a implantação de sistemas de qualidade ou de ferramentas de controle de processos.

\footnotetext{
${ }^{2}$ Para maiores detalhes sobre o conceito de Regime Alimentar vide capítulo 2 deste trabalho.
} 
De acordo com Freeman (1982), uma empresa pode adotar diferentes posicionamentos estratégicos com relação à inovação, definindo seu caráter competitivo. Dentre estes posicionamentos estão:

* Estratégia ofensiva: aplicada por empresas intensivas em Pesquisa e Desenvolvimento (P\&D), pioneiras na introdução de novos produtos no mercado.

* Estratégia defensiva: aplicada por empresas intensivas em $\mathrm{P} \& \mathrm{D}$, mas que não são capazes de produzir produtos originais, apenas respondem às inovações alcançadas pelas empresas líderes, aproveitando-se dos mercados das ampliações do mercado.

* Estratégia imitativa: empresas apresentam alta capacitação em engenharia de produção e de projetos, possuindo alguns diferenciais para competir com as empresas inovadoras, tais como mercados cativos, proteção política ou menores custos.

* Estratégia dependente: empresas que não realizam P\&D, dependendo de seus clientes para acesso às especificações dos produtos a serem fabricados

* Estratégia tradicional: empresas que atuam em setores com baixo dinamismo tecnológico, também não realizando atividades de P\&D.

* Estratégia oportunista: empresas que ocupam nichos de mercado, se aproveitando oportunidades pouco relacionadas com $\mathrm{P} \& \mathrm{D}$, mesmo que em setores intensivos em P\&D.

Vale a pena destacar o papel das universidades e centros de pesquisa no processo de inovação, contribuindo através de incentivos e, muitas vezes, funcionando como "carro-chefe" na condução de pesquisas em melhorias de produtos, de processos e de gestão. No caso específicos de empresas de pequeno porte, estes centros geralmente se constituem nas únicas fontes de informações e apoio no processo inovativo. 


\subsubsection{Canais de distribuição}

Canal ou via de distribuição é a denominação do "conjunto de indivíduos ou organizações que se encarregam de levar o produto/serviço ao local onde o cliente potencial de se encontra, no momento conveniente e em condições de transferir sua posse" (Cobra, 1989 apud Silva \& Batalha, 2001).

Os canais de distribuição constituem em um quesito de muita importância para uma empresa, representando a maneira como ela comercializa os seus produtos. Algumas empresas possuem seu sucesso garantido graças ao acesso a canais de distribuição fortes, como é o caso do acesso a grandes pontos-de-venda como super e hipermercados.

Por outro lado, muitas empresas possuem dificuldades em decolar seus produtos ou serviços por dificuldades de acesso a canais de distribuição que tenham condições de alavancar suas vendas.

Desta maneira, por mais que uma empresa possua condições internas positivas e ofereça produtos e serviços de qualidade, seu sucesso (ou fracasso) pode ser definido pelos canais de distribuição que ela possui (ou não possui). Este fator é particularmente importante para a indústria de alimentos. As empresas da indústria alimentícia necessitam, na maioria das vezes, de pontos-de-venda para apresentar seus produtos ao consumidor, o que torna maior a sua dependência de firmas revendedoras destes produtos.

Cabe aqui salientar o conceito de cadeia buyer-driven ${ }^{3}$. Este termo se refere a cadeias de produção que possuem o comando centrado especificamente nas empresas distribuidoras dos produtos da cadeia, como é o caso dos hipermercados, por exemplo. Vários segmentos da indústria alimentícia pertencem a cadeias desta natureza. Uma empresa processadora de molhos de tomate, por exemplo, possui uma considerável dependência dos postos de venda para inserir seus produtos no mercado, uma vez que ficaria difícil montar um posto de venda exclusivo para tal produto. Já as empresa de alimentos pertencentes ao ramo de fast-food, por exemplo,

\footnotetext{
${ }^{3}$ Em contraste com esta definição, há o conceito de producer-driven chain, referindo-se à cadeia comandada pelo produtor principal da mesma, como é o caso do papel de comando desempenhado pelas montadoras sobre as empresas de autopeças na indústria automobilística.
} 
não possuem esta dependência, uma vez que normalmente possuem seus próprios pontos-de-venda.

De acordo com esta definição, apresenta-se aqui as formas de distribuição apontadas por Costa (1987) apud Silva \& Batalha (2001) que normalmente são utilizadas por firmas agroalimentares, a saber:

* Distribuição dos produtos de massa, como conservas, molhos, beneficiados: normalmente são utilizados grandes pontos-de-venda como supermercados e grandes atacadistas, processo este chamado de distribuição intensiva;

* Distribuição de produtos como fast-food para pontos específicos de venda: distribuição exclusiva.

Neves (1999) complementa esta idéia através dos conceitos apresentados na Figura 3.6. Nela, o pesquisador ressalta o atacado, o varejo e os serviços de alimentação como os maiores e mais importantes agentes de distribuição de alimentos e bebidas. Estes se apresentam como fundamentais para que uma empresa possa planejar suas fontes de distribuição. O autor ainda destaca a possibilidade das vendas diretas entre indústria e consumidores finais, principalmente com a evolução do comércio eletrônico.

Sproesser (2001) ressalta a importância do comércio varejista no oferecimento de inúmeros serviços que são parte integrante das cadeias alimentares como a seleção de produtos, o transporte, armazenamento, marcação de preços, promoção de produtos, a venda, o pós-venda, entre outros. 


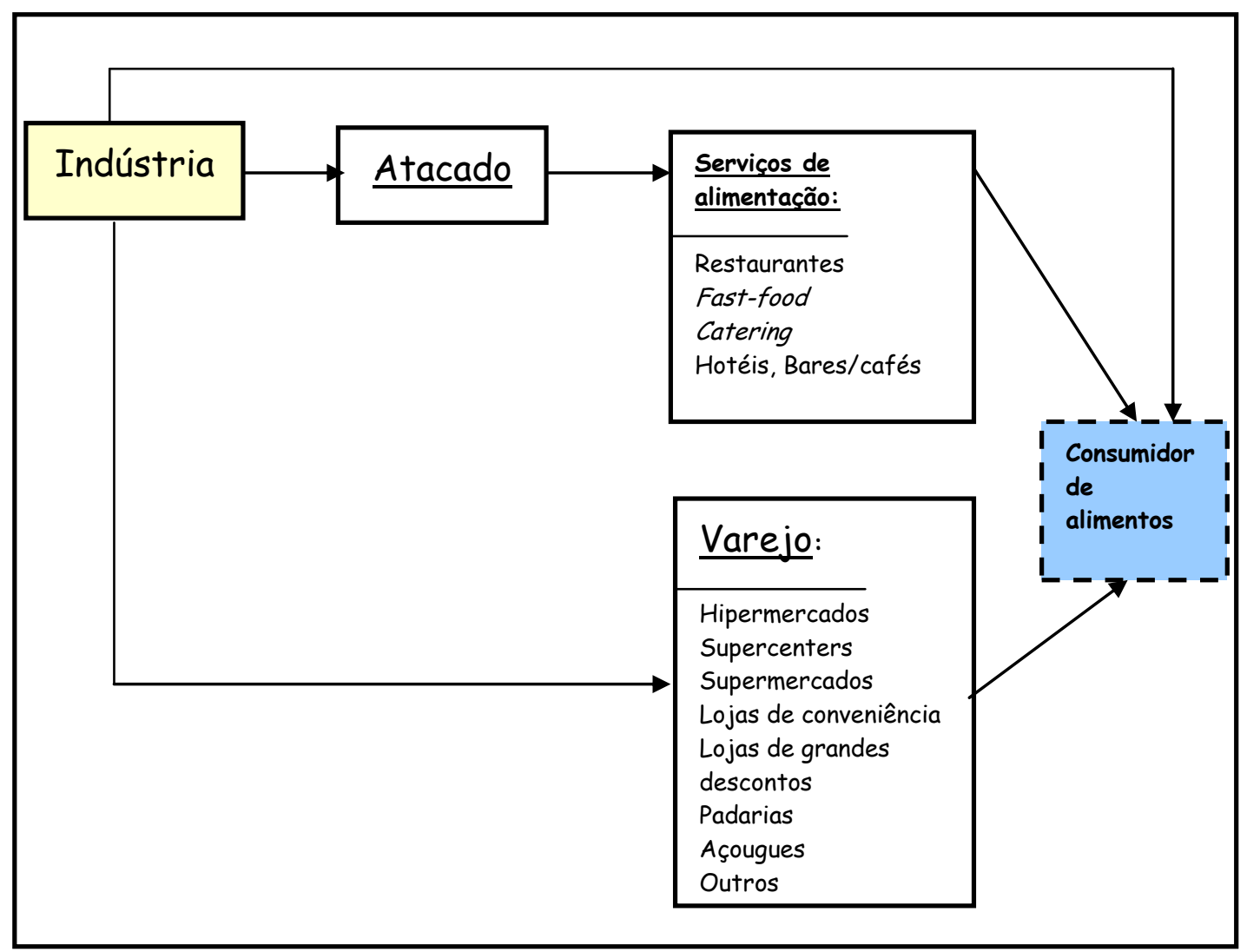

Figura 3.6: Os canais de distribuição para alimentos. Fonte: adaptado de Neves (1999).

Uma tipologia utilizada para a classificação dos canais de diz respeito ao comprimento do canal (Sproesser, 2001). Esta classificação leva em conta o número de agentes econômicos que integram um canal e a repartição das funções entre estes agentes. Por esta classificação, um canal pode ser direto, quando o produtor negocia diretamente com o consumidor. Pode também ser indireto curto, onde as vendas são realizadas do produtor diretamente para o varejista e deste para o consumidor, e indireto longo, onde o atacadista intermedia as vendas do produtor para o varejista. Além desta intermediação, o atacadista efetua as funções de armazenamento e de divisão dos lotes em unidades compatíveis com as necessidades dos clientes.

Sproesser (2001) ressalta, ainda, que a presença de intermediários pode ser positiva quando possibilita a redução de custos comerciais, regulariza o fluxo da demanda e proporciona ganhos de produtividade a uma dada cadeia agroalimentar. 
Porém, estes efeitos podem ser negativos à cadeia produtiva quando não agregam valor ao produto ou há a prática de margens muito elevadas pelo serviço prestado.

Finalizando este tópico destaca-se que uma alternativa comercial que pode ser utilizada pelas empresas de uma dada localidade para inserirem seus produtos em mercados seria a formação de consórcios de distribuição, excluindo a figura de intermediários, encurtando, assim, o canal de distribuição, minimizando efeitos negativos da presença de intermediários.

\subsection{Principais opções estratégicas de firmas agroindustriais}

A base de competitividade da indústria de alimentos esteve tradicionalmente na agricultura. Para a indústria alimentícia é importante manter um fluxo contínuo de abastecimento de matérias-primas, sem formação de estoques. Pelo fato da sua produção estar direcionada para o consumidor final, o padrão de concorrência e as estratégias competitivas do setor tendem a ser pautados pelo posicionamento e consolidação da marca, ampla e diversificada demanda, rapidez na entrega, relações com os fornecedores, confiabilidade do sistema de transporte e disponibilidade de mão-de-obra.

Desta maneira, Silva \& Batalha (2001), apontam cinco principais opções estratégicas que podem ser adotadas por firmas agroindustriais: especialização, integração vertical, diversificação, inovação e fusões/aquisições e de corte. A Tabela 3.7 apresenta as características de cada uma destas opções. 
TABELA 3.7: Principais opções estratégicas associadas a firmas agroindustriais.

\begin{tabular}{|c|c|c|c|}
\hline Opção estratégica & Característica & Vantagens & Desvantagem \\
\hline Especialização & $\begin{array}{l}\text { Concentração em dado } \\
\text { segmento de mercado ou na } \\
\text { utilização de dada tecnologia. } \\
\text { Utilizada principalmente por } \\
\text { pequenas empresas na busca da } \\
\text { ocupação de nichos de mercado } \\
\text { não ocupados por grandes } \\
\text { grupos. }\end{array}$ & $\begin{array}{l}\text { Facilidades no processo } \\
\text { de gestão interna da } \\
\text { firma e } \quad \text { bom } \\
\text { conhecimento } \\
\text { necessidades das } \\
\text { cliente. }\end{array}$ & $\begin{array}{l}\text { Risco associado à } \\
\text { participação de um só } \\
\text { mercado. }\end{array}$ \\
\hline $\begin{array}{l}\text { Integração } \\
\text { vertical }\end{array}$ & $\begin{array}{l}\text { Integração das atividades a } \\
\text { montante e a jusante da } \\
\text { atividade principal da empresa. }\end{array}$ & $\begin{array}{l}\text { Apropriação de lucros } \\
\text { dos mercados situados } \\
\text { a montante e a jusante } \\
\text { da atividade original da } \\
\text { empresa; } \\
\text { favorecimento da } \\
\text { atividade original. }\end{array}$ & $\begin{array}{l}\text { Alto investimento } \\
\text { necessário; aumento da } \\
\text { complexidade de gestão; } \\
\text { aumento dos riscos } \\
\text { associados ao negócio. }\end{array}$ \\
\hline Diversificação & $\begin{array}{l}\text { Aumento do leque de produtos } \\
\text { oferecido pela empresa e/ou } \\
\text { atuação da empresa em um novo } \\
\text { mercado. }\end{array}$ & $\begin{array}{l}\text { Expansão do negócio } \\
\text { associado à empresa. }\end{array}$ & $\begin{array}{l}\text { Risco de inadequação } \\
\text { (falta de sinergia) entre } \\
\text { os novos negócios com os } \\
\text { negócios originais da } \\
\text { empresa. }\end{array}$ \\
\hline Inovação & $\begin{array}{|lr|}\text { Busca de melhorias } \\
\text { tecnológicas associadas ao } \\
\text { produto oferecido pela } \\
\text { empresa. }\end{array}$ & \begin{tabular}{|lr} 
Grande atratividade \\
quando calcada em \\
características \\
difícil imitação pela \\
concorrência \\
aprovação do mercado. \\
\end{tabular} & $\begin{array}{l}\text { Risco de baixos ganhos } \\
\text { competitivos quando as } \\
\text { inovações se fazem sobre } \\
\text { paradigmas tecnológicos } \\
\text { ultrapassados. }\end{array}$ \\
\hline $\begin{array}{l}\text { Fusões } \\
\text { aquisições }\end{array}$ & $\begin{array}{l}\text { Processo de concentração de } \\
\text { uma empresa em um dado setor } \\
\text { agroindustrial. }\end{array}$ & $\begin{array}{l}\text { Obtenção de economias } \\
\text { de escala, maior } \\
\text { coordenação do } \\
\text { mercado, alcance de } \\
\text { sinergias operacionais } \\
\text { e financeiras. }\end{array}$ & $\begin{array}{l}\text { União com empresas } \\
\text { culturalmente } \\
\text { discrepante. }\end{array}$ \\
\hline Corte & $\begin{array}{l}\text { Focada em ações que visam o } \\
\text { corte de despesas ou de dadas } \\
\text { linhas de produtos, fechamento } \\
\text { de unidades. }\end{array}$ & $\begin{array}{l}\text { Eliminação de setores } \\
\text { ou linhas de produtos } \\
\text { dispendiosas e pouco } \\
\text { competitivas, } \\
\text { aumentando o foco da } \\
\text { empresa para seus } \\
\text { negócios principais. }\end{array}$ & $\begin{array}{l}\text { Pode ocorrer saída } \\
\text { precipitada de um dado } \\
\text { mercado com potencial de } \\
\text { crescimento. }\end{array}$ \\
\hline
\end{tabular}

Fonte: Elaborada a partir de Silva \& Batalha (2001).

Analisando o setor de alimentos é possível diferenciar as estratégias utilizadas pelas companhias multinacionais presentes no Brasil, e estratégias de sobrevivência utilizadas por empresas de menor porte, que normalmente possuem como única opção estratégica a atuação em nichos de mercado deixados pelas grandes empresas, com produtos de baixo custo (estratégias genéricas).

As empresas líderes do setor de alimentos passaram a articular estratégias de custo e diferenciação e a estabelecer competências em várias áreas como logística de 
abastecimento, desenvolvimento de novos produtos, processo produtivo e no seu sistema de distribuição. Amplas redes de comercialização passam a ser fundamentais para a competitividade (Cruz et al., 2000).

Desta maneira, as estratégias das empresas produtoras de alimentos estão centradas nas competências, no desenvolvimento de produtos com maior valor adicionado (cortes especiais, alimentos semi-prontos, alimentos modificados) e no processo técnico com inovações na área de biotecnologia.

\section{SÍNTESE DO CAPÍTULO}

A competitividade de uma empresa pode ser definida como a sua capacidade em ser bem sucedida em mercados em que haja concorrência. Desta maneira, ela pode ser assegurada internamente, através de investimentos em sua cadeia de valor, na busca de vantagens que lhes assegure a competitividade. Dentre os fatores competitivos para uma empresa destacam-se: custo, qualidade, flexibilidade, desempenho nas entregas e inovação.

Porém, a competitividade também pode ser entendida por uma visão ampliada, segundo características presentes (ou ausentes) em uma dada porção territorial (região). As regiões também possuem aspectos que podem ser trabalhados para assegurar a competitividade das empresas nela presentes. Isto pode se dar através de elaboração de políticas públicas favoráveis, pela simetria de poder entre os atores que compõem o tecido institucional local, e também através de ações como a promoção do local através de selos de origem, apoio à inovação, e pela busca ao acesso a canais de distribuição robustos.

Como o objetivo deste trabalho centra-se no estudo de micro e pequenas empresas, interessa o estudo específico da competitividade deste segmento. Para tanto, o próximo tópico possui, então, o intuito de caracterizar estas empresas e analisar os fatores que definem a competitividade para este conjunto. 


\section{MICRO E PEQUENAS EMPRESAS E REDES DE COOPERAÇÃO}

Neste capítulo são apresentados os conceitos de micro e pequenas empresas bem como a descrição de seu posicionamento no panorama nacional dos negócios. Também são discutidos os fatores atualmente associados à definição da competitividade destas empresas mediante à globalização, destacando o papel da formação de redes de cooperação como uma alternativa estratégica para a obtenção de vantagem competitiva entre MPE's.

Dentre as formas de cooperação revisadas, destaque maior é dado aos aglomerados ou clusters, foco de atenção deste trabalho.

\subsection{As micro e pequenas empresas no Brasil}

As micro e pequenas empresas possuem importância fundamental na economia mundial, uma vez que representam uma parcela significativa no PIB tanto nos países desenvolvidos quanto nos países em desenvolvimento. No caso brasileiro, esta parcela está na casa dos 20\%, como pode ser visualizado pela Tabela 4.1. Além disso, estas empresas contribuem em boa proporção para a geração de empregos e para o desenvolvimento local e regional.

Segundo o IBGE, existem no Brasil por volta de 3,5 milhões de empresas, sendo que $98 \%$ delas se constituem em empresas de micro e pequeno porte. Desta maneira, estas empresas possuem uma representatividade bastante significativa na economia nacional, sendo as mesmas responsáveis por $59 \%$ das pessoas empregadas no país. A Tabela 4.1 ilustra alguns dos dados principais referentes a estas empresas. 
TABELA 4.1: Participação das MPE's na economia nacional

\begin{tabular}{|l|c|}
\hline \multicolumn{1}{|c|}{ Variável } & MPE's (\%) \\
\hline Número de empresas & 98 \\
\hline Pessoal ocupado & 59 \\
\hline Faturamento & 28 \\
\hline PIB & 20 \\
\hline Empresas exportadoras & 29 \\
\hline Valor das exportações & 1,7 \\
\hline
\end{tabular}

Fonte: SEBRAE (2002)

A classificação do porte de uma empresa pode ter como base tanto o seu faturamento bruto anual quanto o número de funcionários que a empresa emprega em sua operações. A Tabela 4.2 demonstra a classificação utilizada em cada um dos critérios.

TABELA 4.2: Porte das empresas de acordo com os critérios faturamento anual e número de funcionários.

\begin{tabular}{|l|c|c|}
\hline \multicolumn{1}{|c|}{ Porte } & Critério Faturamento Anual (R\$) & Critério número de funcionários \\
\hline Micro & Até 244 mil & Até 19 \\
Pequena & 244.001 a 1,2 milhão & De 20 a 99 \\
Média & 1,2 milhão a 35 milhões & De 100 a 499 \\
Grande & Acima de 35 milhões & Acima de 500 \\
\hline
\end{tabular}

Fonte: Lei Federal n. 9.841, de 05/10/1999.

Estas empresas vêm sendo alvo de atenção por parte de analistas econômicos devido a seu potencial de geração de renda e de emprego. Durante o pós-fordismo estas empresas foram o ponto de atenção devido a seus atributos de flexibilidade e rapidez de adaptação às demandas do mercado. Além disso, as MPE’s possuem um contato muito próximo com o seu mercado consumidor. Com isso, conseguem responder mais rapidamente e eficientemente às mudanças ocorridas nele, bem como proporcionar alterações, inovações ou o aparecimento de novos bens ou serviços de acordo com a necessidade e interesse de seus clientes. Também apresentam-se mais aptas a adaptar seus produtos de acordo com os interesses, os costumes e as tradições da região na qual estão instaladas. Assim, políticas de inovação voltadas para essas 
empresas podem ser um instrumento de estímulo ao crescimento e à competitividade de diversos setores industriais.

Ressalta-se, assim, que o potencial para desenvolver a competitividade das micro e pequenas empresas nacionais é substancial também do ponto de vista da diversificação de mercados, já que o mercado da maioria destas empresas é regional ou nacional, e a exportação ainda é muito pequena.

Porém, apesar da relevância das empresas de pequeno porte mediante o cenário nacional, a maioria destas empresas no Brasil apresenta alguns fatores que tornam sua posição competitiva ameaçada. Normalmente, estas empresas operam com equipamentos e instalações de teor tecnológico defasado, realizam baixo investimento em pesquisa e desenvolvimento, apresentam-se lentas e relutantes quanto à adoção de inovações gerenciais e organizacionais, além de apresentarem baixo relacionamento cooperativo, quer seja com seus fornecedores quanto com empresas similares.

Além disso, Kruglianslas (1996) apresenta alguns dados relativos às MPE's no ano de 1995 que evidenciam a luta destas empresas pela sobrevivência: 50\% das MPE's apresentou atraso do pagamento de obrigações financeiras; 52\% apresentaram atrasos em impostos; $27 \%$ deixaram de pagar seus fornecedores e $15 \%$ possuíam algum tipo de dívida.

\subsection{Características gerenciais associadas às MPE's}

As empresas de pequeno porte possuem algumas características estruturais que as diferenciam das empresas de grande porte, não podendo, então, serem visualizadas meramente como uma grande empresa com escalas menores de vendas, ativos e empregados (Las Casas, 2001) (Welsh \& White, 1981).

Um ponto relevante desta diferenciação das pequenas empresas diz respeito à ausência das características de uma organização burocrática encontradas nas empresas de maior porte: formalidade, impessoalidade e profissionalismo. Segundo Motta (2001), nas empresas de menor porte geralmente ocorre o oposto: pessoalidade, informalidade e a administração não profissional. 
Tais características são reflexos do estilo gerencial destas empresas. A maioria delas, por exemplo, possui seu gerenciamento realizado pelo proprietário do empreendimento, que muitas vezes utiliza elementos da família para ocupar os demais postos gerenciais, definindo um caráter familiar, com prevalecimento das relações pessoais e da administração não profissional. A Tabela 4.3 resume alguns pontos relevantes da administração não profissional que normalmente ocorre nas empresas de pequeno porte.

TABELA 4.3: Como os proprietários diferem dos "gerentes profissionais".

\begin{tabular}{|c|c|c|}
\hline Características & Proprietários & Gerentes Profissionais \\
\hline $\begin{array}{l}\text { Motivação } \\
\text { Orientação } \\
\text { Profissional }\end{array}$ & 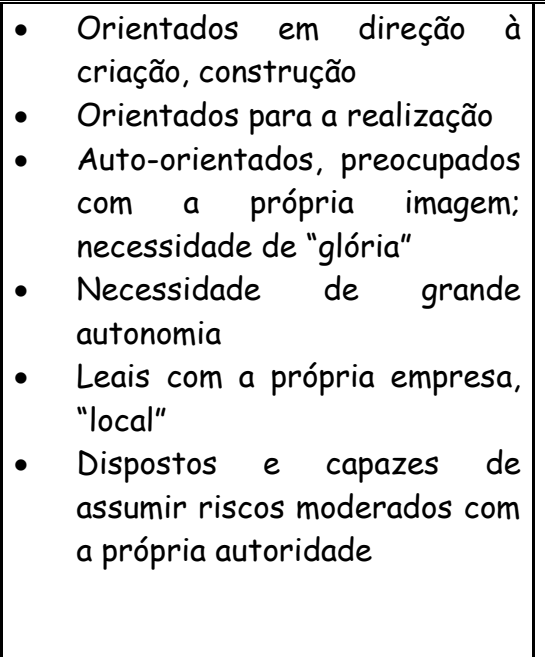 & 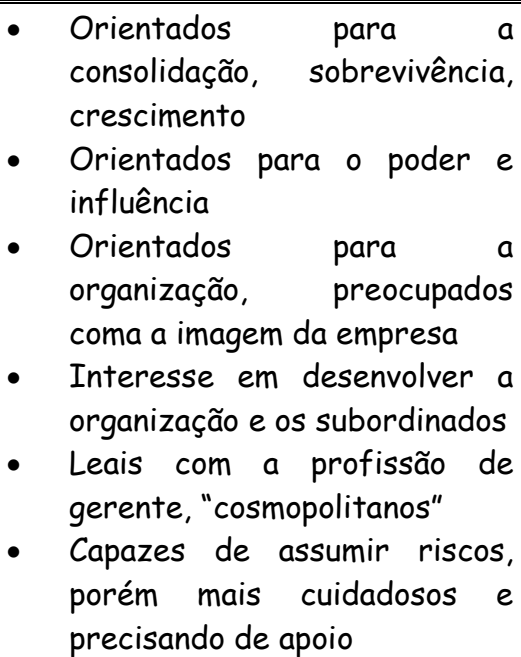 \\
\hline Orientação Analítica & 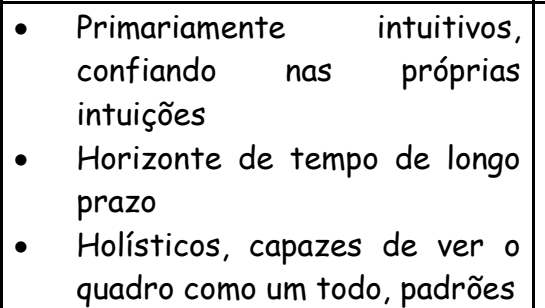 & $\begin{array}{l}\text { - Basicamente analíticos, mas } \\
\text { cuidadosos com as intuições } \\
\text { - Horizonte de tempo de curto } \\
\text { prazo } \\
\text { - Específicos, capazes de ver } \\
\text { detalhes e suas consequências }\end{array}$ \\
\hline
\end{tabular}

Fonte: Longenecker et al. (1998) Administração de pequenas empresas. São Paulo:

Makron Books Ltda. p.424.

Outro ponto bastante relevante destas empresas está relacionado à falta de formalidade na condução dos negócios. Isto se deve, sobretudo, à ausência da formalização de normas básicas de organização.

A tabela 4.4 ilustra alguns dos efeitos desta falta de obediência aos preceitos da organização burocrática, relacionando-os com principais causas para a sua ocorrência. 
TABELA 4.4: Principais características gerenciais associadas às empresas de pequeno porte.

\begin{tabular}{|c|c|}
\hline Efeitos & Principais causas \\
\hline $\begin{array}{l}\text { - Informalidade nas comunicações } \\
\text { - } \quad \text { Carência de relatórios de desempenho }\end{array}$ & $\begin{array}{l}\text { - } \quad \text { Sistemas de informações deficientes } \\
\text { - } \quad \text { Ausência de normas e comunicação formal } \\
\text { (escrita) }\end{array}$ \\
\hline $\begin{array}{l}\text { - Deficiências com relação à descrição e } \\
\text { definição da estrutura organizacional } \\
\text { - } \quad \text { Administração "intuitiva": descrença no } \\
\text { uso de técnicas avançadas de gestão e de } \\
\text { consultoria externa. } \\
\text { - Acentuada dependência do dono no } \\
\text { - } \quad \text { Relacionamentos bastante pessoais }\end{array}$ & $\begin{array}{l}\text { - } \quad \text { Centralização da administração no } \\
\text { proprietário }\end{array}$ \\
\hline $\begin{array}{l}\text { - Falta de atenção às atividades de } \\
\text { planejamento }\end{array}$ & $\begin{array}{l}\text { - Preocupação com resultados imediatos e com } \\
\text { o gerenciamento da rotina }\end{array}$ \\
\hline
\end{tabular}

Fonte: Elaboração própria a partir de Las Casas (2001), Motta (2001) e Longenecker et al. (1998).

\subsection{A competitividade em micro e pequenas empresas}

Apesar da situação de desvantagem que podem apresentar as empresas de menor porte para competir em um mercado globalizado, elas possuem algumas particularidades que se apresentam como fontes de competitividade quando comparadas às empresas de maior porte. Elas normalmente possuem estrutura mais enxuta, o que forneceria um ambiente mais propício para a pesquisa e desenvolvimento, além de desempenhar atividades com baixa intensidade de capital e alta intensidade de mão-de-obra, o que lhe confere maiores condições de produção de produtos diferenciados. Além disso, estas empresas são normalmente mais ágeis e flexíveis que as empresas maiores (Casarotto \& Pires, 1999).

Plawgo \& Chapman (1999) enumeram alguns fatores tradicionais que definiam vantagens competitivas de pequenas empresas atuando em uma região periférica, ou seja, afastada dos grandes centros industriais tradicionais, sobre as firmas de maior porte.

- Produção de bens para o atendimento das necessidades específicas do mercado local: a vantagem é que certos produtos estão "naturalmente protegidos", pois 
devem ser produzidos localmente por problemas de perecibilidade de matériasprimas ou por alto custo de transporte;

- Pré-processamento de matérias-primas para a redução de seu peso ou volume para eventual transporte ou uso por outras firmas;

- Investimento em manufatura tradicional ( hand-made ou artesanato);

- Produção de produtos de nicho: grandes empresas frequentemente consideram certos segmentos de mercado além de seu escopo de interesse, por ser muito especializado ou muito pequeno;

- Integração vertical: muitos processos tecnológicos podem ser divididos em uma série de estágios. Pequenas empresas podem ser competitivas em sub-montagens, acabamento de produtos, entre outros estágios.

- Muitas empresas de pequeno porte possuem administração familiar, possuindo, por este motivo, economia com o pagamento de pessoal especializado e clara motivação para o trabalho pesado.

Entretanto, as mudanças ocorridas em termos de tecnologia e de estrutura de mercado levam a repensar estes fatores tradicionais de competitividade, uma vez que as empresas de menor porte encontram-se cada vez mais expostas à concorrência internacional. As vantagens competitivas definidas anteriormente e fortemente calcadas na "localidade", acabam por perder parte de sua importância. Desta maneira, os autores destacam alguns fatores de competitividade, tidos como decisivos dentro do novo paradigma global, e que devem ser considerados também pelas MPE's:

- preço

- qualidade

- modernidade

- habilidade para seguir tendências da moda

- complexidade da oferta

- embalagem

- entregas rápidas e pontuais

- formas atrativas de pagamento 
- tecnologia de produção

- qualidade de gerenciamento de pessoal

- marketing efetivo

- $\quad \mathrm{P} \& \mathrm{D}$

- $\quad$ acesso a canais de distribuição.

De acordo com estes fatores competitivos, dentre as grandes desvantagens apresentadas pelas micro e pequenas empresas está sua falta de capacidade para obter bom desempenho em todas as etapas da cadeia de valor (logística, produção, $\mathrm{P} \& \mathrm{D}$, marketing). E, em tempos de globalização, esta integração da cadeia de valor se apresenta como um fator fundamental para a competitividade de uma empresa (Casarotto Filho \& Pires, 1999).

Esta falta de capacidade em gerenciar e obter bom desempenho todas as atividades relacionadas à cadeia de valor se deve à existência de problemas comuns para as micro e pequenas empresas em todos os países, sejam eles desenvolvidos ou em vias de desenvolvimento. A obsolescência das máquinas, devido às dificuldades que essas empresas encontram para obter um crédito, é um exemplo disso. Segundo Lèbre (2001), no Brasil existem diversas linhas de crédito especiais para pequenas empresas. Entretanto, a simples exigência de estar em dia com as obrigações fiscais para obter crédito já exclui a maioria das empresas. Assim, as MPE’s possuem condições de crédito menos favoráveis que as grandes companhias, o que, por sua vez, inibe os esforços de atualização tecnológica.

Além disso, a sua capacidade de inovação depende de vários fatores, dentre os quais menciona-se o sistema nacional de inovação e fatores relacionados à organização do setor. Enquanto para grandes companhias ter maior capacidade de inovação é resultado de uma ampla capacidade de pesquisa e desenvolvimento, para as pequenas empresas essa capacidade depende da sua maior flexibilidade e capacidade de adaptação a mudanças no mercado, e ao ambiente interno delas, que induz a uma maior motivação por parte de seus empregados, favorecendo, assim, o desenvolvimento da produtividade e da competitividade através de inovações.

As pequenas empresas podem não ter consciência dos possíveis ganhos que uma inovação pode trazer, mas a maioria dessas empresas gera ou adota uma 
inovação quando percebe claramente que existem oportunidades de novos negócios ligadas a essas inovações. Algumas MPE's produzem peças e componentes para as empresas de maior porte, muitas vezes estimuladas pela própria empresa consumidora. Podem ocorrer transferências de conhecimentos e de tecnologias da empresa consumidora para que, com isso, os produtos possuam a qualidade e as especificações desejadas pela empresa que futuramente irá adquirir os produtos de empresas menores.

Segundo Souza et al. (2000), dentre os problemas recorrentes do processo de inovação tecnológica destacam-se os custos e a escala de produção. Os custos operacionais de equipamentos com certa sofisticação exigem treinamento de operadores, manutenção permanente e, em muitos casos, instalações especiais e controladas. O acionamento do sistema implica em preparos de estoque de material em processo na velocidade exigida, realização de outras operações, como acondicionamento do material processado ou mesmo outra fase de operação. O funcionamento harmônico do sistema depende de conhecimentos, estudos, testes e adaptações.

A escala de produção é outro fator determinante para a definição de inovação tecnológica. O dimensionamento de um equipamento depende de estudos completos que envolvem não exclusivamente a operação da máquina, mas todo o contexto de uma empresa.

Estas empresas apresentam, ainda, outras características peculiares, inerentes à sua estrutura e ao seu porte, diferenciando-as das grandes empresas. As empresas de menor porte, normalmente, apresentam um controle individual do proprietário, com $\mathrm{o}(\mathrm{s})$ sócio(s)-gerente envolvido(s) em todas as decisões da empresas.

Outro aspecto de importância é a baixa capacitação gerencial que decorre do fato de que essas empresas são, na sua maior parte, familiares. Esse espírito conservador e familiar reduz o horizonte de planejamento da empresa para o curto prazo e cria barreiras para ingressar em novos mercados. A Tabela 4.5 ilustra as principais vantagens e também as desvantagens das MPE's aqui discutidas. 
TABELA 4.5: Vantagens e desvantagens associadas às MPE's.

\begin{tabular}{|c|l|l|}
\hline $\begin{array}{c}\text { Característica } \\
\begin{array}{c}\text { Estrutura } \\
\text { enxuta }\end{array}\end{array}$ & \multicolumn{1}{|c|}{ Vantagem } & \multicolumn{1}{|c|}{ Desvantagem } \\
\hline Porte pequeno & $\begin{array}{l}\text { Maior facilidade para produção de de } \\
\text { produtos diferenciados. Flexibilidade. } \\
\text { Agilidade. Produção de estágios da } \\
\text { integração vertical. }\end{array}$ & $\begin{array}{l}\text { Incapacidade de gerenciar todas } \\
\text { as atividades da cadeia de valor. }\end{array}$ \\
\hline Inovação & $\begin{array}{l}\text { Rapidez de adaptação às demandas do do } \\
\text { mercado. Investimento na manufatura } \\
\text { tradicional (hand-made). }\end{array}$ & $\begin{array}{l}\text { Obsolescência de maquinário } \\
\text { devido a condições de crédito } \\
\text { desfavoráveis. }\end{array}$ \\
\hline $\begin{array}{c}\text { Gerenciamento } \\
\text { familiar }\end{array}$ & $\begin{array}{l}\text { Economia com o pagamento de pessoal } \\
\text { especializado e motivação para o o } \\
\text { trabalho pesado. }\end{array}$ & $\begin{array}{l}\text { Baixa capacitação gerencial, com } \\
\text { redução dos horizontes de de } \\
\text { planejamento para o curto-prazo. }\end{array}$ \\
\hline $\begin{array}{c}\text { Atuação em } \\
\text { mercados locais } \\
\text { e regionais }\end{array}$ & $\begin{array}{l}\text { Produção de produtos "naturalmente } \\
\text { protegidos" por alto custo de transporte } \\
\text { ou perecibilidade. Produtos de nicho. }\end{array}$ & $\begin{array}{l}\text { Falta de condições gerais para a } \\
\text { exportação de produtos e atuação } \\
\text { no mercado internacional. }\end{array}$ \\
\hline
\end{tabular}

Todos os problemas mencionados são agravados quando as empresas persistem em ficar isoladas e resistem à formação de parcerias, redes entre empresas, alianças, entre outras formas de cooperação.

Estudos em países em desenvolvimento, por exemplo, demonstram que as micro e pequenas empresas que se localizam dentro de clusters têm mais chances de se manter no mercado e de crescer do que as empresas similares que atuam de forma isolada.

Desta forma, o estabelecimento de relações de cooperação entre este tipo de empresas no Brasil pode ser um instrumento importante para estimular o crescimento dessas empresas e, como consequência, da economia regional, uma vez que esta cooperação permite a elas a obtenção de ganhos de escala e escopo ao gerar externalidades positivas, minimizando os problemas comuns a todas elas. Conforme observado por Bianchi (1996), num mercado aberto, as MPE's só podem ser competitivas se forem especializadas, e operarem num contexto de cooperação onde a entrada de novas firmas seja estimulada e a ação de free-riders seja evitada, de modo a sustentar a capacidade de inovação e crescimento da rede.

Desta maneira, a formação de redes de cooperação se apresenta como opção para o bom desempenho das etapas da cadeia de valor, onde cada empresa desempenha uma função, de acordo com sua competência principal. 
A busca da competitividade, ou mesmo da sobrevivência, tem levado muitas empresas a efetuarem modificações em suas naturezas organizacionais. Isto se dá tanto entre grandes companhias, através de fusões e aquisições entre as mesmas, quanto com pequenas e médias empresas, por meio do estabelecimento de alianças e parcerias.

Baseados na curva U de Porter (1990), Casarotto Filho \& Pires (1999) endossam este raciocínio incluindo a possibilidade da obtenção de vantagem competitiva de MPE's pela formação de redes de cooperação entre as mesmas (Figura 4.1). Os autores argumentam que a flexibilidade oriunda da formação de redes de MPE's abriria uma nova forma de competir: através de vantagens oriundas do conjunto liderança em custo e diferenciação.

De acordo com os autores, uma pequena empresa teria as seguintes formas de competir:

- Diferenciação de produto associado ou não a um nicho de mercado;

- Liderança de custo, através do fornecimento para uma grande empresa (rede topdown $\left.n^{1}\right)$

- Flexibilidade/custo pela participação de redes de cooperação.

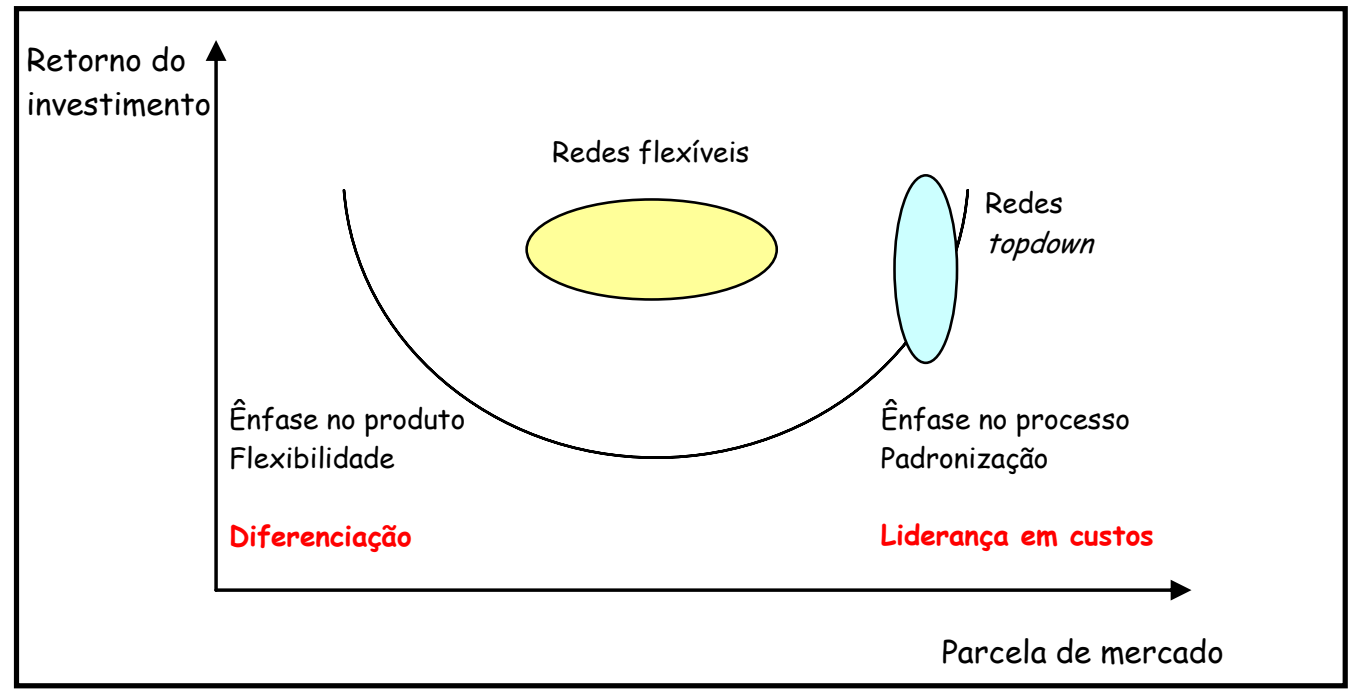

Figura 4.1: Ampliação das estratégias competitivas genéricas para MPE's (Casarotto \& Pires, 1999. p.29).

\footnotetext{
${ }^{1} O$ conceito de redes top-down encontra-se na Tabela 4.6 deste trabalho.
} 
Seguindo este raciocínio, o tópico a seguir trata das diversas maneiras que as empresas possuem para a colaboração com outras empresas através da abordagem das redes de cooperação.

\subsection{Redes de cooperação}

Segundo Batalha \& Silva (2001), o conceito de redes de empresas refere-se a uma "estrutura de ligações entre atores de um sistema social qualquer". Já Jarillo (1998) define redes como acordos resolutos de longo-prazo entre organizações distintas, mas ligadas pelo lucro que permitem a essas empresas ganhar ou manter vantagem competitiva sobre seus concorrentes, pela otimização dos custos das atividades e minimização dos custos de coordenação. Estas empresas fazem isso porque, em muitas indústrias, a melhor estratégia consiste em coordenar todo o sistema de negócio, mas fazer isso através da integração vertical levaria a pesadas penalidades em sua eficiência.

Pode-se diferenciar na literatura dois enfoques associados ao conceito de rede de empresas. Um primeiro deles é o enfoque intra-empresa, ou seja, diz respeito a ligações e contratos fechados entre membros de setores funcionais diferentes como forma de diminuir a burocracia própria do sistema administrativo (Charam, 1997).

Outro enfoque dado ao conceito de redes de empresas está ligado às relações existentes inter-empresas, ou seja, aos conjuntos de relações externas à uma dada organização, incluindo sua teia global de alianças e joint ventures (Grandori \& Soda, 1995). Santos et al. (1994) apontam dois tipos básicos de redes de cooperação interempresariais: redes verticais de cooperação e redes horizontais.

$\mathrm{Na}$ Figura 4.2, as setas ilustradas em azul representam as relações entre empresas que formariam as redes verticais, ou seja, redes formadas entre uma empresa e seus fornecedores, por exemplo.

Já as redes horizontais estão representadas pelas setas vermelhas, indicando as relações estabelecidas entre uma empresa e seus concorrentes ou empresas de ramos complementares a seu negócio. 


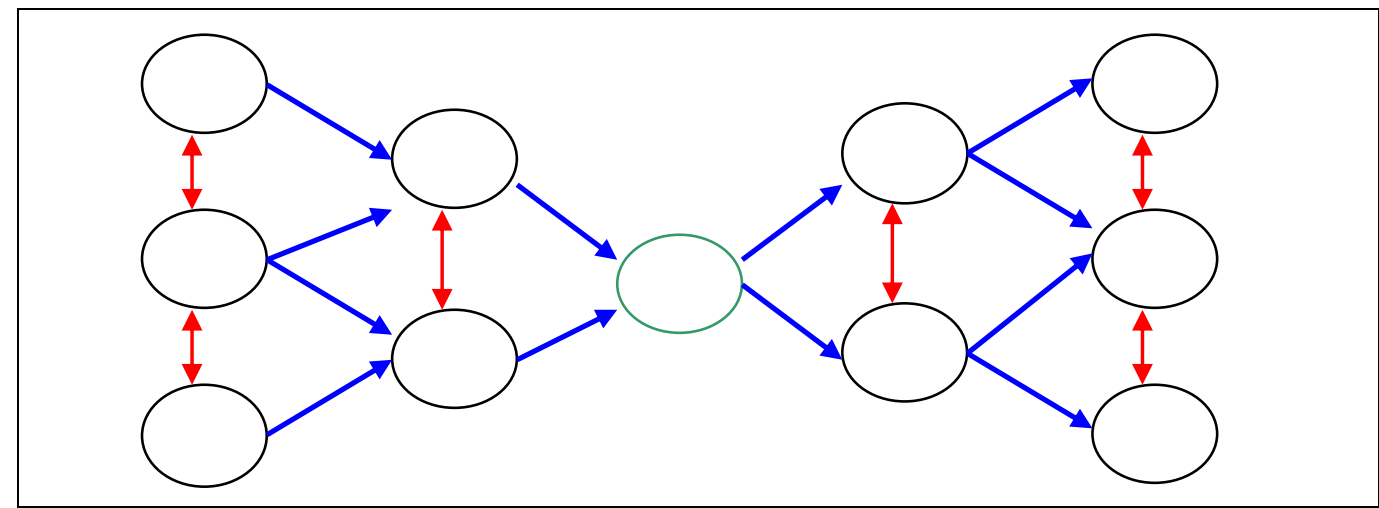

Figura 4.2: Redes de empresas dos tipos horizontal $(\longrightarrow)$ e vertical $(\longleftrightarrow)$.

Ainda dentro da tipificação de redes de cooperação inter-empresas, Grandori \& Soda (1995) identificam três tipos básicos de redes, sob o critério da formalidade ou informalidade das relações entre as empresas: redes sociais (informais), redes burocráticas (existência de contrato formal) e redes proprietárias (formalização de acordos relativos ao direito de propriedade).

As redes, como qualquer forma organizacional, possuem requerimentos administrativos. Do ponto de vista da empresa central, onde a reputação não é apenas preservada, mas constantemente reforçada, cultivar confiança e internalizar riscos é absolutamente essencial. Para os outros membros da rede será o constante esforço para agregar valor à rede (através da adaptação, aprendizado e difusão daquele aprendizado) determinando, com isso, seu sucesso futuro (Jarillo, 1998).

Assim, a cooperação entre empresas pode viabilizar o atendimento de necessidades de difícil satisfação caso cada empresa tenha atuação isolada. Amato Neto (1999) elenca as seguintes vantagens da cooperação produtiva:

- Combinação de competências;

- Divisão do ônus referentes à realização de pesquisas tecnológicas;

- Partilhamento de riscos e custos relativos à exploração de novas oportunidades;

- Oferecimento de uma linha de produtos mais completa e diversificada;

- Compartilhamento de recursos, sobretudo dos sub-utilizados por uma dada empresa;

- Fortalecimento do poder de compra; 
- Obtenção de maior força para a competição no mercado internacional;

- Fortalecimento da força competitiva.

A cooperação existente nas redes tem inovado as relações intra e interempresas, levando à criação de uma nova arquitetura organizacional (Batalha \& Silva, 2001). As tabelas 4.6, 4.7 e 4.8 explanam algumas das principais formas de cooperação inter-empresas. 
TABELA 4.6: Formas de cooperação entre empresas: rede de empresas

\begin{tabular}{|c|c|c|c|c|}
\hline Denomina & \multicolumn{2}{|c|}{ Tipologia } & Exemplo & Característica principal \\
\hline \multirow{10}{*}{$\begin{array}{l}\text { Redes de } \\
\text { Empresas }\end{array}$} & \multirow[t]{2}{*}{ Sociais } & $\begin{array}{l}\text { Simétricas (sem } \\
\text { centralização } \\
\text { de poder) }\end{array}$ & $\begin{array}{l}\text { Pólos e Distritos de Alta } \\
\text { Tecnologia }\end{array}$ & \multirow[t]{2}{*}{ Informalidade nas relações } \\
\hline & & $\begin{array}{c}\text { Assimétricas } \\
\text { (presença de um } \\
\text { agente central) }\end{array}$ & $\begin{array}{l}\text { Rede italiana de } \\
\text { fornecimento da Beneton }\end{array}$ & \\
\hline & \multirow[t]{2}{*}{ Burocráticas } & $\begin{array}{c}\text { Simétricas (sem } \\
\text { centralização } \\
\text { de poder) }\end{array}$ & $\begin{array}{l}\text { Associações comerciais como } \\
\text { cartéis, federações e } \\
\text { consórcios. }\end{array}$ & \multirow[t]{2}{*}{$\begin{array}{l}\text { Existência de um contrato } \\
\text { formal }\end{array}$} \\
\hline & & $\begin{array}{l}\text { Assimétricas } \\
\text { (presença de um } \\
\text { agente central) }\end{array}$ & $\begin{array}{l}\text { Redes de agências, acordos } \\
\text { de licenciamento e franquias. }\end{array}$ & \\
\hline & \multirow[t]{2}{*}{ Proprietárias } & Simétricas & $\begin{array}{l}\text { Empregadas na regulação de } \\
\text { atividades de P\&D e de alto } \\
\text { conteúdor tecnológico } \\
\text { (Joint Ventures) }\end{array}$ & \multirow[t]{2}{*}{$\begin{array}{l}\text { Formalização de acordos } \\
\text { relativos ao direito de } \\
\text { propriedade entre os } \\
\text { acionistas de empresas }\end{array}$} \\
\hline & & Assimétricas & $\begin{array}{l}\text { Relacionam investidor de um } \\
\text { lado e empresa de outro } \\
\text { (Capital Ventures) }\end{array}$ & \\
\hline & \multicolumn{2}{|c|}{ Verticais + } & $\begin{array}{l}\text { Relações de fornecimento do } \\
\text { complexo automobilístico }\end{array}$ & \\
\hline & \multicolumn{2}{|c|}{ Horizontais + } & Consórcios entre empresas & $\begin{array}{lll}\text { Cooperação entre } & \text { uma } \\
\text { empresa } & e & \text { seus } \\
\text { concorrentes } & & \end{array}$ \\
\hline & \multicolumn{2}{|c|}{ Topdown. } & Indústria automobilística & $\begin{array}{l}\text { Formada por uma empresa- } \\
\text { mãe que coordena sua } \\
\text { cadeia de fornecedores e } \\
\text { sub-fornecedores em vários } \\
\text { níveis. Fornecedor } \\
\text { dependente das estratégias } \\
\text { da empresa-mãe, não tendo } \\
\text { flexibilidade nem poder de } \\
\text { influência na rede. }\end{array}$ \\
\hline & \multicolumn{2}{|c|}{ Flexíveis • } & $\begin{array}{l}\text { Consórcio verticalizado e } \\
\text { horizontalizado }\end{array}$ & $\begin{array}{l}\text { Cooperação entre empresas } \\
\text { independentes, formando } \\
\text { um grupo administrado como } \\
\text { se fosse uma grande } \\
\text { empresa. }\end{array}$ \\
\hline
\end{tabular}

- Classificação associada a GRANDORI \& SODA (1995)

+ SANTOS et al (1994)

- CASSAROTTO \& PIRES (1999) 
TABELA 4.7: Formas de cooperação entre empresas: alianças estratégicas

\begin{tabular}{|c|c|c|c|}
\hline Denominação & Tipologia & Exemplo & Característica principal \\
\hline \multirow[t]{3}{*}{$\begin{array}{c}\text { Alianças } \\
\text { Estratégicas* }\end{array}$} & Consórcios & $\begin{array}{l}\text { Consórcio de } 6 \text { empresas } \\
\text { americanas para viabilizar as } \\
\text { pesquisas sobre fibras óticas } \\
\text { em Ohio. }\end{array}$ & $\begin{array}{l}\text { Empresas com necessidades } \\
\text { similares criam uma nova } \\
\text { entidade que preencha a } \\
\text { necessidade de todas. }\end{array}$ \\
\hline & Joint Ventures & $\begin{array}{l}\text { Colaboração entre empresas na } \\
\text { indústria automobilística ( } G M \text { e } \\
\text { Suzuki) para a criação de } \\
\text { carros pequenos. }\end{array}$ & $\begin{array}{l}\text { Constituição de um novo } \\
\text { negócio ou ampliação de } \\
\text { algum existente }\end{array}$ \\
\hline & Parcerias & $\begin{array}{l}\text { Redes que frequentemente } \\
\text { incluem fornecedores, clientes } \\
\text { e funcionários. }\end{array}$ & $\begin{array}{l}\text { Envolvimento de vários } \\
\text { parceiros em diferentes } \\
\text { estágios de um processo de } \\
\text { negócio. }\end{array}$ \\
\hline
\end{tabular}

* Classificação associada a KANTER (1990)

TABELA 4.8: Outras formas de cooperação entre empresas.

\begin{tabular}{|c|c|c|c|}
\hline Denominação & Tipologia & Exemplo & Característica principal \\
\hline Clusters & Aglomerados & $\begin{array}{l}\text { Mármores de Carrara (Itállia), } \\
\text { Vale do Silício (EUA), Calçados } \\
\text { do Vale dos Sinos-RGS (Brasil) }\end{array}$ & $\begin{array}{l}\text { Empresas que cooperam } \\
\text { tendo como base a } \\
\text { localização das plantas. }\end{array}$ \\
\hline $\begin{array}{l}\text { Organizações } \\
\text { Virtuais }\end{array}$ & $\begin{array}{l}\text { Redes dinâmicas de } \\
\text { cooperação }\end{array}$ & Projeto IMMPAC - México. & $\begin{array}{l}\text { Combinação temporária } \\
\text { através da telemática de } \\
\text { competências essenciais de } \\
\text { empresas independentes } \\
\text { que cooperam entresi }\end{array}$ \\
\hline $\begin{array}{c}\text { Incubadora de } \\
\text { Empresas }\end{array}$ & & $\begin{array}{l}\text { Cooperação universidade- } \\
\text { empresas. }\end{array}$ & $\begin{array}{l}\text { Cooperação inter- } \\
\text { institucional com o objetivo } \\
\text { de criar um ambiente } \\
\text { propício para o nascimento e } \\
\text { desenvolvimento de } \\
\text { empresas. }\end{array}$ \\
\hline $\begin{array}{l}\text { Parques } \\
\text { Tecnológicos }\end{array}$ & & Parqtec - São Carlos & $\begin{array}{l}\text { Destina-se a acelerar a } \\
\text { transformação do resultado } \\
\text { de pesquisas em produtos e } \\
\text { processos, envolvendo PME's } \\
\text { - }\end{array}$ \\
\hline
\end{tabular}


Dentre estas diversas possibilidades para a formação de redes de cooperação interempresariais expostas nos quadros anteriores, a forma de cooperação cuja existência está condicionada à localização das empresas é o aglomerado ou cluster. Como este trabalho trata do estudo de empresas concentradas em um cluster, esta é, então, a forma de cooperação aqui enfocada.

\subsection{Cluster: definição e principais características}

Conforme anteriormente citado, uma das possibilidades de integração entre empresas pode se dar através dos chamados clusters ou aglomerados. De acordo com Porter (1998), clusters se definem como concentrações geográficas de empresas e instituições, ligadas por aspectos que podem ser compartilhados e complementados entre si. Estas empresas cooperam e colaboram para o desenvolvimento de vantagens econômicas e estratégicas.

Estudos envolvendo concentrações geográficas de empresas em um mesmo local já datam de bastante tempo. A noção de Distrito Industrial proposta por Marshall (1919) foi amplamente estudada e estendida para o entendimento das relações das concentrações de empresas na Itália, em estudos realizados por Piore \& Sabel (1984), Becattini (1994), entre outros. Estes estudos estendem-se em análises de casos para várias regiões e países, como Courlet \& Pecquer (1994); Saives, (2000); Casarotto Filho \& Pires (1999); Ganne (1994); Barroso (1998).

Humphrey \& Schimitz (2000) dividem a literatura que enfoca a proximidade geográfica de empresas como força competitiva em quatro linhas principais, a saber:

- Nova Geografia Econômica

- Estudos Empresariais

- Ciência Regional

- Estudos de Inovação

Estas quatro linhas de estudos provêm de diferentes tradições de pensamento, cada qual enfocando partes específicas das inter-relações entre empresas dentro de 
um aglomerado. Porém, todas concordam com os benefício e vantagens advindas destas interações.

Dentre as grandes vantagens relacionadas à concentração de empresas de um mesmo ramo em um mesmo local geográfico diz respeito à possibilidade de cooperação entre as diversas empresas e entre seus fornecedores, de tal forma a ganhar vantagem econômica e estratégica com a localização. Neste sentido é que surge o conceito de cluster, sendo este uma cadeia de relações entre as empresas, fornecedores de insumos, clientes e instituições que possuem, além da localização, interesses em compartilhar as vantagens da proximidade. Estas empresas cooperam e colaboram para ao desenvolvimento de vantagens econômicas e estratégicas. Este conceito de cluster industrial tem sido utilizado como ferramenta para o desenvolvimento de regiões e países bem como para a inserção no mercado mundial de empresas de pequeno e médio porte. Através da cooperação, pequenas e médias empresas podem construir um arranjo que permita um ganho de eficiência tanto em escala quanto escopo.

As vantagens de um cluster são inúmeras, mas a redução dos custos de transação e as vantagens logísticas da aglomeração parecem ser de especial importância. Além disto, as vantagens advindas da compra conjunta de insumos também devem ser destacadas.

Um outro aspecto que tem sido citado pela literatura é a possibilidade de ganhos de flexibilidade com o compartilhamento da mão-de-obra pela empresas do cluster que tenham demandas sazonais devido às características do segmento que atuam (Saives \& Bienfant, 2000). Ainda com relação à mão-de-obra, a configuração em clusters permite às empresas uma melhoria com relação à qualidade e à especialização dos funcionários, uma vez que é possível elaborar esforços conjuntos para o envolvimento de instituições como universidades e institutos de pesquisas da região para que ofereçam treinamentos e apoio técnico em geral.

Através da cooperação empresarial pode-se obter importantes ganhos mútuos como, por exemplo, a implantação de consórcios de exportação e de participação em feiras nacionais e internacionais para a divulgação dos produtos relacionados com o cluster que, divulgados desta forma, tendem a adquirir um destaque maior. 
Obviamente estas vantagens acabam por tornar mais competitivas as indústrias de dada região, principalmente com relação à maior inserção no mercado interno e à entrada no mercado externo. Por tudo isso, os aglomerados desempenham, ainda, o papel de imãs na atração de investimentos externos (Porter, 1998).

TABELA 4.9: Vantagens associadas ao conceito de cluster.

\begin{tabular}{||l|l||}
\hline \multicolumn{1}{|c|}{ Categoria } & \multicolumn{1}{|c|}{ Vantagens associadas } \\
\hline Estrutural & $\begin{array}{l}\text { Mão-de-obra especializada; } \\
\text { Compartilhamento de mão-de-obra. }\end{array}$ \\
\hline Comercial & $\begin{array}{l}\text { Formação de consórcios de } \\
\text { vendas/exportações, participação em feiras; } \\
\text { Divulgação das empresas através da promoção } \\
\text { do conjunto (cluster). }\end{array}$ \\
\hline Regional & Atração de investimentos externos. \\
\hline Econômica & $\begin{array}{l}\text { Redução dos custos de transação; } \\
\text { Vantagem logística; } \\
\text { Compra conjunta de insumos. }\end{array}$ \\
\hline
\end{tabular}

\subsubsection{Os clusters e a competitividade regional}

As vantagens associadas aos clusters se relacionam intimamente ao aumento da competitividade das empresas nele inseridas. Além disso, destaca-se a sua força no que tange à articulação do desenvolvimento do espaço territorial em que ele se encontra. Desta maneira, seu conceito está amplamente associado à definição de competitividade regional exposta no capítulo 3 deste trabalho.

Seguindo esta linha, Casarotto Filho \& Pires (1999) sugerem um modelo geral de rede para o desenvolvimento de um sistema econômico local que pode ser associado ao conceito de cluster aqui apresentado. Estes autores defendem que os novos modelos de desenvolvimento local implicam participação de toda a sociedade, isso porque os instrumentos de organização empresarial e as formas de estruturação de redes de empresas requerem um pacto político, estratégico e operativo entre as empresas e instituições. O modelo sugerido pelos autores está apresentado pela figura 4.3. 


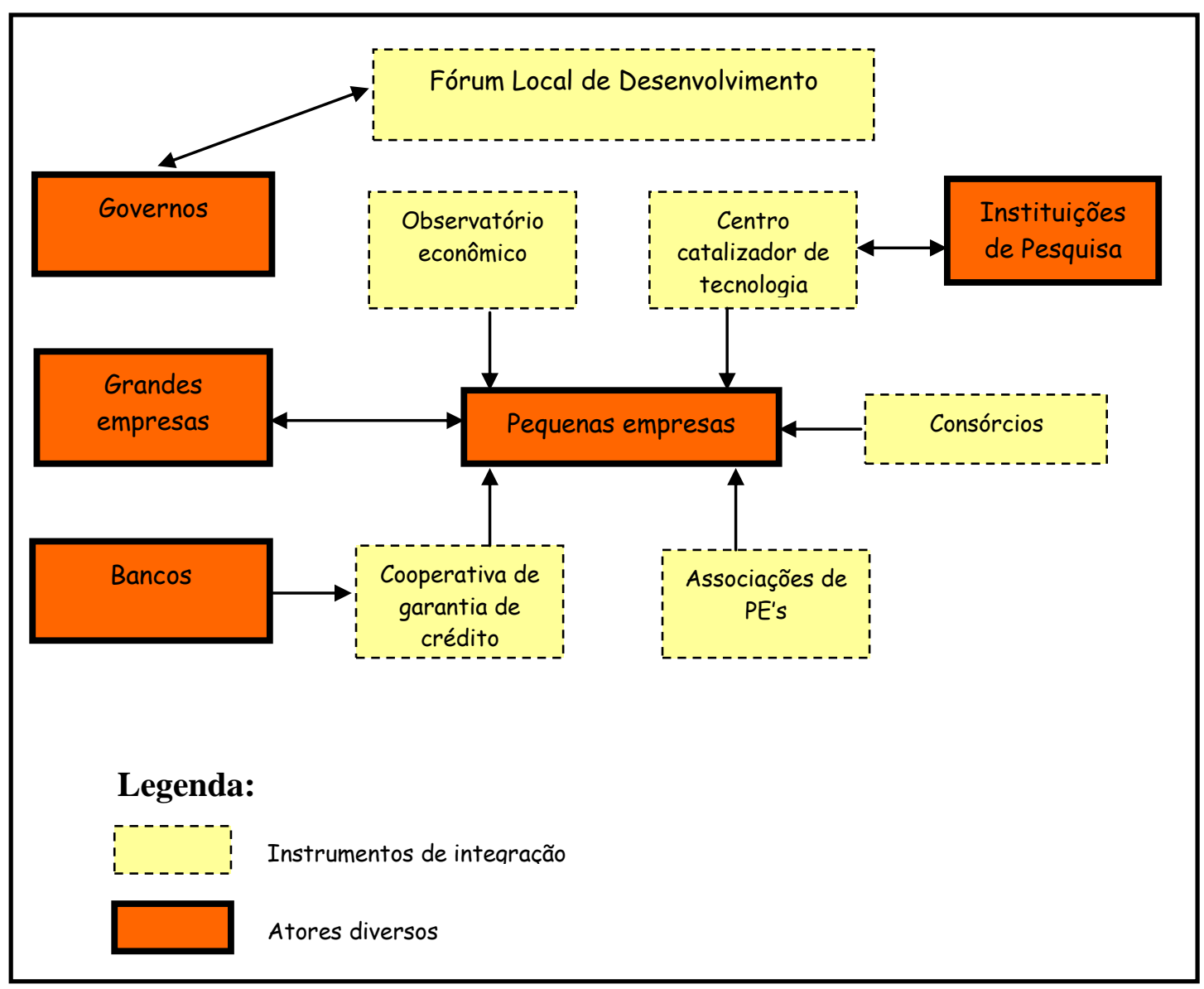

Figura 4.3: Modelo geral de rede para o desenvolvimento de um sistema econômico local (cluster). Fonte: adaptado de Casarotto Filho \& Pires (1999).

Mediante este modelo, além das empresas presentes no local, destaca-se a participação de outros atores para que seja proporcionado o desenvolvimento de um cluster. No que tange o desenvolvimento e acesso à tecnologia, por exemplo, destaque deve ser dado ao papel das universidades e dos centros de pesquisa locais no apoio às empresas da localidade. Este papel se associa principalmente às MPE's, pois são essas que contam com menos recursos aplicados nas questões de inovação.

Outras instituições que apresentam papel relevante no apoio às empresas do cluster são os bancos e as cooperativas de crédito. O apoio financeiro advindo destes apresenta-se como fator fundamental para o desenvolvimento das empresas locais, sobretudo das MPE's, que normalmente carecem de apoio monetário e de dificuldades para conseguir linhas de crédito. 
O governo, através de suas representações federais, estaduais e municipais, também possui papel relevante para o desenvolvimento de um cluster, principalmente no tocante à elaboração de políticas públicas favoráveis ao desenvolvimento local.

Por fim, destaca-se o papel das associações na representação das empresas, em especial devido à sua função de representar os interesses empresariais em pról do desenvolvimento das empresas presentes no cluster.

Desta maneira, os clusters, sob a ótica da competitividade regional, possuem nos fatores de seu ambiente fortes indícios de sua situação competitiva. Seguindo esta linha, o tópico a seguir aborda os principais fatores relacionados ao cluster encontrados no ambiente econômico, no papel das instituições públicas e privadas e nas políticas governamentais.

\subsubsection{Economia}

O desenvolvimento de um cluster depende tanto da economia interna do conglomerado quanto da economia externa.

Porter (1999), mostra que em economias ricas e desenvolvidas, os métodos de produção, os produtos, e os serviços estão em constante evolução, pois há necessidade de sustentar salários crescentes através da inovação. Nestas economias, os aglomerados são mais visíveis em relação à sua profundidade e amplitude, sendo os laços entre as empresas mais fortes e contínuos.

Já nas economias em desenvolvimento, como é o caso do Brasil, os clusters são mais superficiais, tendo menor disponibilidade de componentes, serviços e matériasprimas, que em geral, são provenientes de fontes externas ao local. A formação de clusters neste tipo de economia ocorre por meio de grandes empresas competitivas, que acabam atraindo firmas menores ao seu redor, envolvendo, assim, menos participantes e com menor grau de interação.

As economias em desenvolvimento deparam-se com dificuldades como subdesenvolvimento de instituições, políticas governamentais desestimulantes, deficiências tecnológicas, níveis de educação e qualificação baixos, fatores estes inibidores desenvolvimento. A ausência de aglomerados neste tipo de economia não 
impede as empresas de competir. Porém, inibem o aumento da produtividade e do aprimoramento dos produtos e processos, afetando o crescimento de salários, lucros, padrão de vida e valor dos produtos, uma vez que estes dependem do aumento da produtividade. A presença do aglomerado, por conseguinte, ajuda no processo de desenvolvimento econômico (Porter, 1999).

O desenvolvimento econômico está estreitamente ligado às políticas governamentais. As diferentes políticas adotadas após a Segunda Guerra Mundial mostraram consequiências distintas. As políticas comerciais de muitos países latinos baseavam-se na crença do desenvolvimento econômico por meio da proteção das indústrias domésticas, criando um forte setor industrial devido à industrialização por substituição das importações. Isso gerou uma falta de especialização das empresas e a incapacidade de produção em escala, trazendo uma vasta diferença salarial entre os setores e desemprego, ou seja, o dualismo econômico.

\subsubsection{Governo e Políticas}

O governo desempenha vários papéis a fim de proporcionar o progresso da economia. Os principais são: assegurar a estabilidade macroeconômica e política; aumentar a qualidade e eficiência dos insumos básicos, fomentando as instituições responsáveis por estes, a fim de melhorar a capacidade microeconômica; incentivar a competição, com um sistema tributário justo, leis de incentivo aos consumidores e normas de defesa da concorrência; facilitar o desenvolvimento do aglomerado; e, finalmente, planejar o desenvolvimento econômico a longo prazo. Muitas vezes o progresso é inibido por falta de conhecimento e ações governamentais (Porter, 1999).

Os aglomerados não se constituem através das políticas do governo, mas sim devido às vantagens da localização. $\mathrm{O}$ governo deve incentivar os clusters emergentes ao invés de tentar criar outros. Não há algum aglomerado que não seja importante economicamente. Todos têm potencial produtivo e devem ser incluídos no montante de investimentos do governo, uma vez que cada um se desenvolve diferentemente, fazendo com que suas peculiaridades tornem-se pontos fortes. As iniciativas em relação aos aglomerados focalizam a análise das políticas governamentais (Porter 1999). Os principais recursos do governo utilizados nos 
aglomerados consistem na melhoria do ambiente de negócios em geral, e na remoção de obstáculos que dificultem a produtividade e a inovação, a fim de atrair novas empresas. Muitas destas atitudes podem ser atribuídas às empresas privadas, contudo, algumas políticas governamentais travam o desenvolvimento e somente o Estado tem soberania para corrigi-las. Portanto, qualquer política governamental que gere custos sem retorno futuro deve ser eliminada ou minimizada (Porter, 1999).

Segundo Porter (1998), grande parte das vantagens geradas nos aglomerados estão baseadas nos extravasamentos e externalidades que envolvem entidades governamentais. Krugman \& Obstfeld (1999) definem externalidades como benefícios, que pela dificuldade de mensuração, não têm preço de mercado. Um exemplo é o conhecimento gerado pela pesquisa e desenvolvimento de uma empresa.

O governo pode ajudar o aprimoramento dos aglomerados, porque consegue coletar e organizar as informações mais importantes geradas neles, e à medida que os clusters se desenvolvem, ficam evidentes as mudanças das fontes da vantagem competitiva. As atuações governamentais enfatizam a promoção de encontros entre os participantes, e de forma mais direta, estimulam as universidades e escolas públicas, através de políticas, a suprirem as necessidades do aglomerado, sendo capaz de sofisticar a demanda local e de simplificar regulamentos que estejam atrapalhando o desenvolvimento. O crescimento do aglomerado atrai investimentos estrangeiros, que impulsionam o aparecimento de novas empresas e multinacionais, porém as condições da estrutura local também devem ser otimizadas.

De acordo com Porter (1999) o governo influencia negativamente a competição quando concentra suas políticas em campos abrangentes, como por exemplo bens de capital. Isso pode distorcer o mercado, pois os governantes dão mais importância para um determinado setor. Ao contrário, políticas concentradas nos aglomerados atacam problemas comuns a vários setores envolvidos, nos extravasamentos e nos elos entre as organizações. Isso faz com que as firmas encontrem poucas dificuldades nos diálogos com o governo facilitando o diagnóstico dos problemas. Além disso, encorajam a competição, e motivam o surgimento de bens públicos ou quase públicos, os quais têm grande impacto sobre negócios interconectados. Assim, o retorno obtido é muito maior quando comparado com o retorno sobre os recursos dirigidos às firmas dispersas na economia em geral. 
O cluster é capaz de orientar tipos de políticas distintas, como por exemplo, políticas de exportação, tecnológicas, de investimentos, de treinamentos e educacionais. As políticas governamentais focadas nos aglomerados, por conseguinte, facilitam o ajuste das empresas à nova realidade econômica, reduzindo os riscos da economia local (Porter,1999).

As deficiências das políticas governamentais são minimizadas pela constante avaliação dos aglomerados em busca de soluções rápidas e práticas. A globalização está mudando o foco das ações governamentais, que começam a se preocupar com organizações de alcance mundial, e com isso, os governantes devem fixar padrões mínimos e descentralizar o poder com finalidade de conseguir melhores resultados, uma vez que os governantes de níveis mais baixos possuem uma visão mais nítida das necessidades de cada região, e podem realizar investimentos públicos mais específicos e implementá-los (Porter, 1999).

\subsubsection{Associações Comerciais e Órgãos Coletivos.}

As redes informais, as associações comerciais formais, os consórcios e outros órgãos coletivos têm papel importante no desenvolvimento do cluster, uma vez que institucionalizam os elos entre os participantes. Eles podem representar a maioria ou a totalidade das empresas, tornando a capacidade de influenciar maior. As associações desenvolvem funções de interface com o governo local, estadual e central, e são capazes de organizar feiras, desenvolver programas de treinamento junto com outras instituições, gerenciar consórcios de compradores, coletar informações a respeito do aglomerado, entre outras funções de interesse comum. Quando no aglomerado prevalecem PE's, as quais precisam de escala, as funções das associações comerciais se tornam ainda mais importantes (Porter, 1999).

Os órgãos coletivos são muito importantes para o desenvolvimento do cluster, mas pode-se notar que nem sempre há associações comerciais locais, mas sim as de escopo nacional. Mesmo quando existem, elas priorizam funções de lobby junto ao governo, tornando as outras funções ineficazes, e podendo influenciar negativamente a produtividade local. Um outro problema é que os órgãos abrangem algumas 
empresas do setor, e muitos fornecedores e empresas de setores correlatos ficam de fora (Porter, 1999).

\subsubsection{O cluster completo}

Há diferenças entre um distrito industrial e um aglomerado. Neste primeiro há uma concentração de empresas, mas estas não necessariamente possuem sinergias ou fazem parte de um mesmo setor industrial. Num cluster as organizações necessariamente pertencem ao mesmo ramo industrial, havendo a interação e a cooperação entre si.

Por estes motivos, os aglomerados podem ser chamados de agrupamento competitivo. Quanto à sua origem, eles não acontecem formalmente, como associações ou redes de empresas, ou através de um planejamento feito pelos empresários da região, eles nascem naturalmente, tanto que muitas vezes os empresários não percebem que estão dentro deste cluster e podem tirar vantagens disto (Zaccarelli, 2000).

Bremer \& Gutierrez (1998) advogam algumas características que devem ser apresentadas por um cluster:

- Infra-estrutura: membros devem ter recursos físicos necessários;

- Oportunidades: um cluster deve representar novas oportunidades de negócios para as empresas participantes;

- Imagem e atenção: o agrupamento das empresas facilita a divulgação da imagem do grupo e da região. O relacionamento com o governo, universidades e centros de pesquisas deve melhorar.

Porter (1999) relata que os aglomerados podem variar quanto a amplitude, tamanho e estágio de desenvolvimento. Segundo Zaccarelli (2000), tanto clusters pequenos, como de lojas comerciais, como clusters mais complexos apresentam as mesmas vantagens competitivas, pois as principais características são similares e o aperfeiçoamento destas depende da evolução do cluster. Segundo este autor, as duas maiores vantagens competitivas encontradas nos diferentes exemplos de 
aglomerados são: disponibilidade de ampla linha de produtos, e preços confiáveis. A sua evolução é medida em decênios, pois assim pode-se notar a mudança mais facilmente.

Assim, a grande diferença existente entre o que é definido por aglomerado ou cluster e um simples agrupamento de empresas em um mesmo local diz respeito à dedicação das empresas para um mesmo tipo de produto e à existência de sinergia entre as mesmas.

Zaccarelli (2000) define como um "cluster completo" a concentração de empresas que apresentam as características a seguir mencionadas:

- Alta Concentração Geográfica: é a característica principal de um aglomerado. Nesta concentração a disponibilidade de recursos naturais é muito importante a princípio, mas como mostra Porter existem concentrações onde estes recursos são precários ou nem mesmo existem. Outro fator é a disponibilidade de mão-de-obra da região.

- Existência de todos os tipos de empresas e instituições de apoio relacionadas ao produto do cluster: dentro da concentração geográfica devem haver empresas que executem atividades desde a extração de matéria-prima até a distribuição e comercialização, além de instituições de apoio que realizem atividades como desenvolvimento de produto, organizações de feiras e eventos, transportadoras e armazéns. Um outro ponto importante é a representação perante ao governo, a fim de defender os interesses (lobbies).

- Empresas altamente especializadas: a tendência das organizações não é a verticalização, mas sim se especializarem numa parte da cadeia de valor, o que favorece sobretudo as pequenas e médias empresas.

- Presença de muitas empresas de cada tipo: este fator irá aumentar a competição e a rivalidade entre as empresas, que terão que inovar constantemente para poderem competir, e assim o cluster se desenvolve através da melhoria contínua.

- Total aproveitamento de materiais reciclados ou subprodutos: a viabilidade econômica da reciclagem aumenta quando há uma concentração de empresas, que poderão ter seus lixos reciclados e reaproveitados, trazendo benefícios tanto para a empresa quanto para o meio-ambiente, além de poder se tornar um 
diferencial para a competição com empresas de outros aglomerados ou de empresas geograficamente isoladas.

- Grande cooperação entre empresas: a cooperação ocorre naturalmente e nem sempre é organizada, mas se fosse poderia ter melhor aproveitamento. Quando há cooperação as empresas podem não se beneficiar diretamente, mas como será melhor para o cluster, as organizações terão benefícios indiretos.

- Intensa disputa / substituição seletiva permanente: estar presente num aglomerado não significa ter menos trabalho, pois as imitações acontecem com mais facilidade e as empresas tem que progredir constantemente para obter vantagens em relação as empresas do mesmo cluster. A rivalidade é importantíssima para o aglomerado não ficar estático.

- Uniformidade de nível tecnológico: a tecnologia mais atrasada do aglomerado deve ser substituída, pois a grande diferença do nível tecnológico das empresas não é benéfica para o cluster.

- Cultura da sociedade adaptada às atividades do cluster: na região do aglomerado algumas características do trabalho são absorvidas pela sociedade, trazendo status e reconhecimento para os colaboradores e se tornando uma ferramenta de motivação.

Quanto mais destas características estiverem presentes num local, mais completo será o aglomerado, e mais vantagens competitivas ele terá. É importante entender que as vantagens são do cluster e não particulares a cada empresa integrante.

Por outro lado, podem existir concentrações de empresas que não atendam, necessariamente, a todas as características descritas pelo autor. Assim, pode ser definida uma escala onde um cluster será tanto mais completo quanto maior o atendimento às nove características anteriormente colocadas.

O autor ressalta, ainda, que mesmos incompletos, os clusters já apresentam vantagens com relação à empresas competindo isoladamente.

Porter (1998), por sua vez, ressalta que o aproveitamento dos benefícios e vantagens relativos ao conceito de cluster é proporcional ao grau de desenvolvimento dos mesmos. Segundo o pesquisador, “os aglomerados mais desenvolvidos 
apresentam bases de fornecedores mais profundas e especializadas, um aparato mais amplo de setores correlatos e instituições de apoio mais abrangentes”.

\subsubsection{Fatores fundamentais para a formação de redes de cooperação}

O nascimento e desenvolvimento de redes de empresas dependem de alguns aspectos, dentre os quais Olave \& Amato Neto (2001) ressaltam: cultura da confiança, cultura da competência e cultura da tecnologia.

A cultura da confiança mostra que a confiabilidade entre participantes da rede é essencial para o desenvolvimento desta. Este tipo de cultura envolve ética, cultura e interesse das partes integrantes. A cultura da competência, por sua vez, se relaciona às competências essenciais de cada parceiro no que tange os aspectos materiais, como instalações e equipamentos, e não-materiais como know-how e processos. Já a cultura da tecnologia da informação procura verificar a agilidade dos fluxos de informações e como eles são feitos, pois são de suma importância para o desenvolvimento de redes flexíveis.

Como forma de minimizar os riscos inerentes a esses arranjos, as empresas podem utilizar mecanismos de controle tais como a confiança e a governança (Cabral, 1999).

Somam-se a estes fatores a estrutura da rede de poder local, além do papel das instituições públicas na formulação de políticas de estímulo ao desenvolvimento regional, apoiando a cooperação entre as empresas presentes no cluster.

\subsubsection{Estrutura de Governança}

De acordo com Fleury \& Fleury (2000), o estudo das redes de cooperação produtivas possui como idéia central a identificação das estruturas de poder (governança), onde uma ou mais empresas coordenam e controlam atividades econômicas dispersas. Desta forma, o conceito de governança está associado ao processo de coordenação de atores econômicos, tanto em esferas públicas e privadas quanto nos níveis local e global (Humphrey \& Schimitz, 2000). 
Uma estrutura de governança é definida como um conjunto de ações e instrumentos adequados capazes de induzir à cooperação no interior de uma organização ou entre organizações (Saes, 2000). Este conjunto de ações e instrumentos é constituído por instituições e regras que, em tese, seriam capazes de deter o comportamento oportunista que os atores apresentam em função da racionalidade limitada da qual são dotados.

\subsubsection{Confiança (Trust)}

Buzzell e Ortmeyer (1996) sugerem alguns pontos como uma base para uma parceria próspera: compromisso administrativo, uso de recursos e habilidades tecnológicas adequados, promoção de mudanças na cultura e na estrutura das empresas e promoção de confiança entre sócios.

Para responder à questão de quais seriam as fontes de confiança, Wiliams (1988) apud Nooteboom (1999) traça um paralelo entre confiança e cooperação, considerando duas formas principais de ocorrência de cooperação entre duas partes: as formas chamadas de egotista e não-egotista. Freqüentemente, a confiança baseada em laços de amizade ou em afinidades não é suficiente para embasar a cooperação inter-fimas. Da mesma forma, a busca por interesses próprios e a coerção raramente se mostram eficientes para que haja cooperação. Ter confiança é aceitar, ou negligenciar, a probabilidade subjetiva de que o parceiro não utilizará oportunidades para ter um comportamento oportunista.

TABELA 4.10: Fontes de cooperação

\begin{tabular}{|c|l|}
\hline Egotista & $\begin{array}{l}\text { Coerção ou medo de sanções de alguma autoridade. Vantagem material } \\
\text { ou "interesse". }\end{array}$ \\
\hline Não-egotista & $\begin{array}{l}\text { Éticas: valores, normas de conduta. Laços de amizade, afinidade ou } \\
\text { empatia. }\end{array}$ \\
\hline
\end{tabular}

Fonte: Adaptada de Wiliams (1988) apud Nooteboom (1999). 
Humphrey \& Shimitz (1998) argumentam que os riscos envolvidos na cooperação, por sua vez, englobam três níveis específicos, conforme pode ser visualizado pela tabela 4.11 .

TABELA 4.11: Três níveis para se lidar com o risco da cooperação

\begin{tabular}{|c|l|l|}
\hline Nivel & \multicolumn{1}{|c|}{ Egotista (Sanções) } & \multicolumn{1}{|c|}{ Não-egostista (Confiança) } \\
\hline Macro & $\begin{array}{l}\text { Provisões contratuais que servem para a } \\
\text { maioria dos acordos }\end{array}$ & $\begin{array}{l}\text { Baseada em certificações e informações obtidas } \\
\text { em banco de dados }\end{array}$ \\
\hline Médio & $\begin{array}{l}\text { Regulamentos setoriais que servem para } \\
\text { acordos entre setores }\end{array}$ & Baseada na reputação e nas competências \\
\hline Micro & $\begin{array}{l}\text { Personalizado para cada relação, penaliza } \\
\text { comportamentos oportunistas }\end{array}$ & Baseada em relações de parceria passadas \\
\hline
\end{tabular}

Fonte: adaptado de Humphrey \& Schmitz (1998, p. 82).

A relevância econômica da confiança pode ser enfatizada pelo fato de que ela reduz gastos com especificações e monitorando de contratos, reduzindo incertezas. Isto não só faz com que as transações possuam custo mais baixo e sejam mais agradáveis, mas também reflete em ganhos em flexibilidade. Nooteboom (1999) argumenta que com um contrato formal detalhado é mais difícil, lento e caro modificar termos caso haja a mudança de alguma situação. Contratos formais particularmente detalhados podem dar início a uma relação fundamentada na desconfiança, podendo empurrar as firmas em um círculo maligno de regulamentos e constrangimentos mútuos.

Jarillo (1998) sugere uma maneira de se fazer negócio que não se refere nem à integração vertical, nem à rigidez dos contratos tradicionais. O autor chama de rede estratégica, onde uma companhia faz o papel de controlador central para organizar fluxo de bens e informação entre muitas outras companhias independentes, tendo certeza que os clientes finais adquirirão exatamente o que esperam. Redes estratégicas podem dispor companhias a chance para fazer os investimentos a longo 
prazo necessários em relações específicas, mantendo alta flexibilidade e a direção do empreendimento.

A motivação de uma companhia para unir e ficar dentro de uma rede, é a mesma de um trabalhador se unir a uma companhia: a convicção que trabalhando em equipe ele será mais produtivo e que o aumento da produtividade resultante (ou pelo menos parte dele) será a ele transmitido.

Assim, a habilidade para gerar confiança é a chave para reduzir custos de transação e fazer a existência de uma rede estratégica economicamente possível.

A confiança não pode ser imposta, e provavelmente seu desenvolvimento implicaria em um processo a longo prazo, onde o originador da rede desenvolve, pouco a pouco, relações pessoais e uma reputação para justiça. Isto explica porque muitas redes têm um componente geográfico ou cultural forte, porque é mais fácil começar relações mais íntimas com pessoas com um conhecimento pré-existente da integridade pessoal.

De acordo com McCUNE (1999) é mais fácil criar confiança da estaca zero do que recuperá-la depois da perda. Mas para recuperá-la, caso já tenho sido perdida, é preciso preparar-se para abordar a questão da confiança por um longo período.

\section{SÍNTESE DO CAPÍTULO}

Mediante a inegável importância das MPE’s nos cenários nacional e mundial, torna-se relevante o conhecimento dos meios que podem tornar estas empresas competitivas perante os desafios do ambiente dos negócios.

Como alternativas para o aumento do desempenho e da competitividade destas empresas estão as redes de cooperação. Estas formas de organização visam a dinamização dos resultados individuais a partir da interação e sinergia entre os seus membros.

Neste capítulo, especial atenção foi dada aos clusters, que se constituem em redes de empresas de um mesmo setor que possuem como base de operação um mesmo local. A abordagem da competitividade de empresas presentes em um cluster passa pela competitividade das empresas individuais e pela somatória de seus 
desempenhos, definindo, assim, a competitividade do local em que se inserem (cluster).

Finaliza-se, assim, a Revisão Bibliográfica deste trabalho. No próximo capítulo está exposta a metodologia utilizada para o levantamento dados desta pesquisa. 


\section{METODOLOGIA DE PESQUISA UTILIZADA}

A forma encontrada pela sociedade de legitimar um conhecimento adquirido empiricamente se constitui no método científico (Campomar, 1991).

O método científico, também chamado de metodologia de pesquisa, possui fundamental importância nas pesquisas acadêmicas uma vez que sem ele os resultados das investigações seriam de difícil aceitação. Ele provê subsídios ao planejamento e ao desenvolvimento sistematizado de uma investigação científica a respeito de um fenômeno observado na realidade. Pode-se utilizar um ou vários métodos combinados de observação de maneira a apreender fatos e dados desta realidade, com a intenção de entender, explicar e, se possível ou necessário, aplicá-la em favor de outros eventos ou episódios semelhantes (Berto \& Nakano, 1999).

Desta maneira, o conhecimento científico se constitui em um conhecimento contingente e sistemático, uma vez que suas hipótese tem sua veracidade ou falsidade comprovada mediante experimentos ordenados sistematicamente e constitui-se em conhecimento falível, já que não é definitivo, podendo ser reformulado pelo desenvolvimento de novas técnicas (Lakatos \& Andrade, 1995).

Este capítulo descreve e justifica a metodologia de pesquisa empregada na realização do presente trabalho. Num momento inicial é realizada uma síntese dos conceitos importantes para a análise pretendida por esta tese, advindos da revisão bibliográfica realizada. Posteriormente, são discutidas as principais alternativas de abordagem de pesquisa disponíveis bem como os métodos e instrumentos de coleta de dados. E, na sequência, é proposta a metodologia que orienta este trabalho.

\subsection{Principais conceitos abordados neste trabalho}

Como maneira de situar o leitor com relação à pesquisa realizada, este tópico trata da realização de uma síntese da revisão bibliográfica efetuada, através de conceitos extraídos da literatura de acordo com a tipificação do objeto de estudo aqui 
enfocado: a concentração de MPE's do cluster alimentício do município de Marília/SP.

Assim, inicia-se descrevendo as mudanças ocorridas no cenário mundial dos negócios, sobretudo no agroindustrial, que apontam para algumas tendências importantes: aumento das exigências dos clientes; aumento da concorrência entre as empresas, que agora passa a ser mundial; segmentação de mercados, com a consequente diversificação de produtos; empresas operando com redução máxima de estoques (Sistema de Produção Enxuta) e concentradas em suas core competences; formação de cadeias de produção globais, com o aumento na cooperação entre empresas.

A Figura 5.1 sintetiza estas mudanças, que refletem em novas formas de atuação para as empresas perante o mercado.

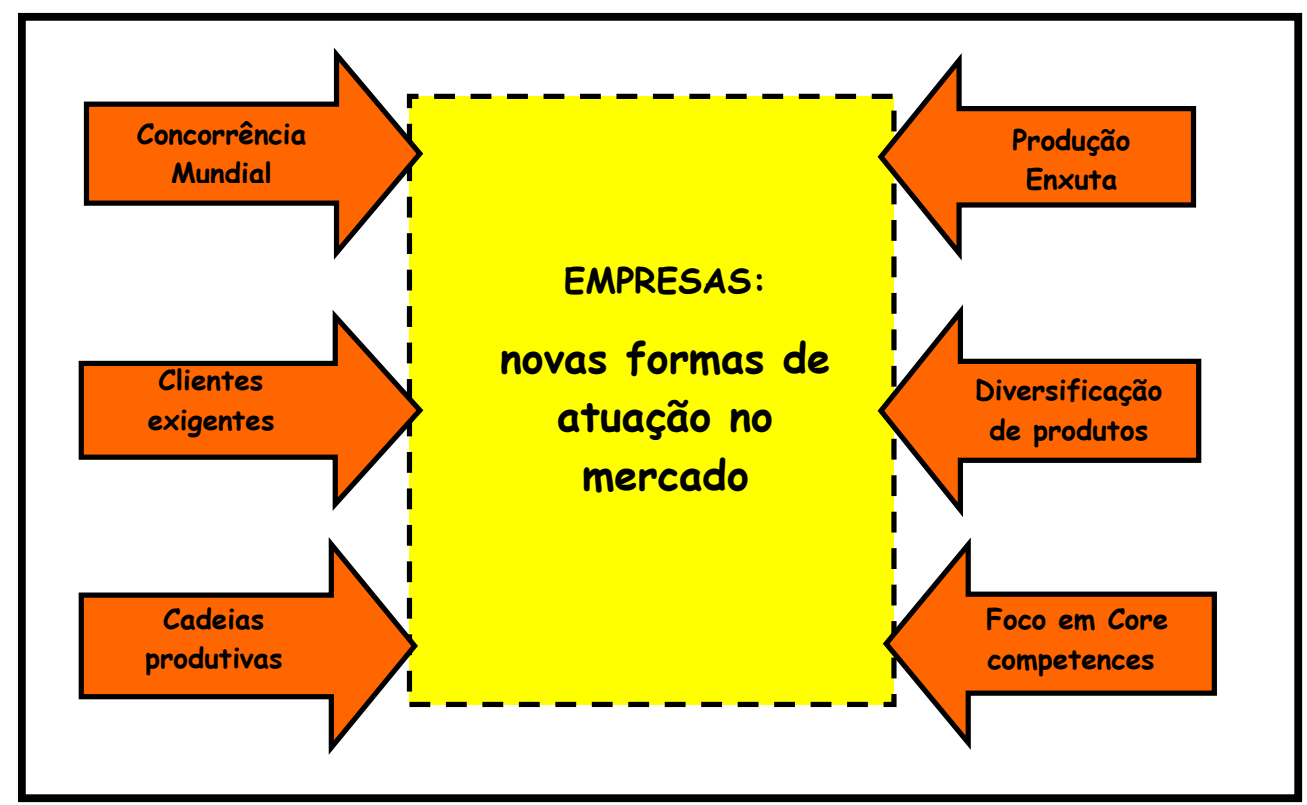

Figura 5.1: A influência das tendências do mercado nas empresas.

Estas novas tendências influenciam as empresas em suas formas de operar e de fazer os seus negócios em mercados cada vez mais exigentes e concorridos, levando a uma redefinição dos chamados fatores competitivos. Os fatores competitivos dentro deste novo ambiente de negócios se definem como a soma dos fatores custo, qualidade, flexibilidade, inovação e desempenho nas entregas. 
Além disso, o próprio conceito de competitividade passa a ter uma visão ampliada, compreendendo tanto a competitividade empresarial quanto à competitividade da porção territorial em que uma empresa está inserida. Assim como as empresas, uma região também possui aspectos que podem ser trabalhados para assegurar a competitividade das empresas nela presentes. Considerando as características do objeto de estudo deste trabalho, alguns fatores competitivos relacionados à região foram considerados. Desta maneira, a figura 5.2 ilustra esta idéia, mostrando os aspectos relativos à competitividade de uma empresa, tanto relacionados ao seu ambiente interno quanto ao ambiente (região) em que ela se insere, complementando a visão apresentada na Figura 5.1.

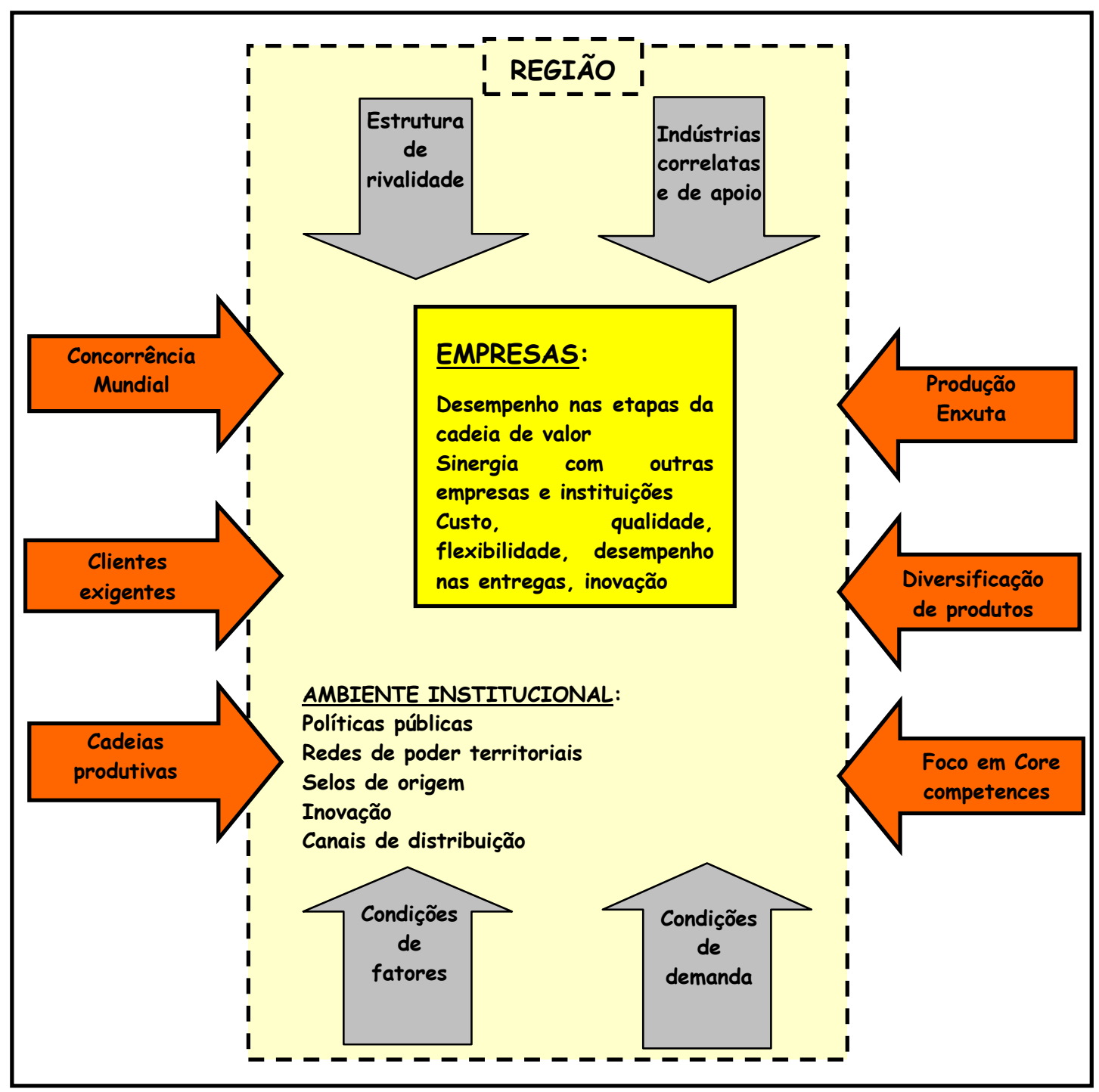

Figura 5.2: Aspectos relativos à competitividade empresarial e regional. 
Por este trabalho tratar especificamente da análise de MPE's, foram levantadas também as alternativas para o aumento da competitividade específica para este grupo. Dentre estas alternativas estão as redes de cooperação interempresariais, com destaque aos chamados clusters, que se constituem em redes de empresas que têm como base de operação um mesmo local. Então, a abordagem da competitividade de empresas presentes em um cluster passa pela competitividade de suas empresas individualmente bem como pela somatória de seus desempenhos, definindo a competitividade da região em que este conjunto de empresas se insere (competitividade regional).

Desta maneira, a figura 5.3 representa a integração destes conceitos com os conceitos apresentados nas Figuras 5.1 e 5.2. De acordo com esta interação, o conceito de região é aqui representado pelo cluster e os desafios das empresas são relativos às empresas de micro e pequeno porte, foco de estudo deste trabalho.

Os conceitos ilustrados na Figura 5.3, então, por representar uma síntese dos conceitos da revisão bibliográfica realizada, foram utilizados como o modelo geral da pesquisa que orienta este trabalho. 


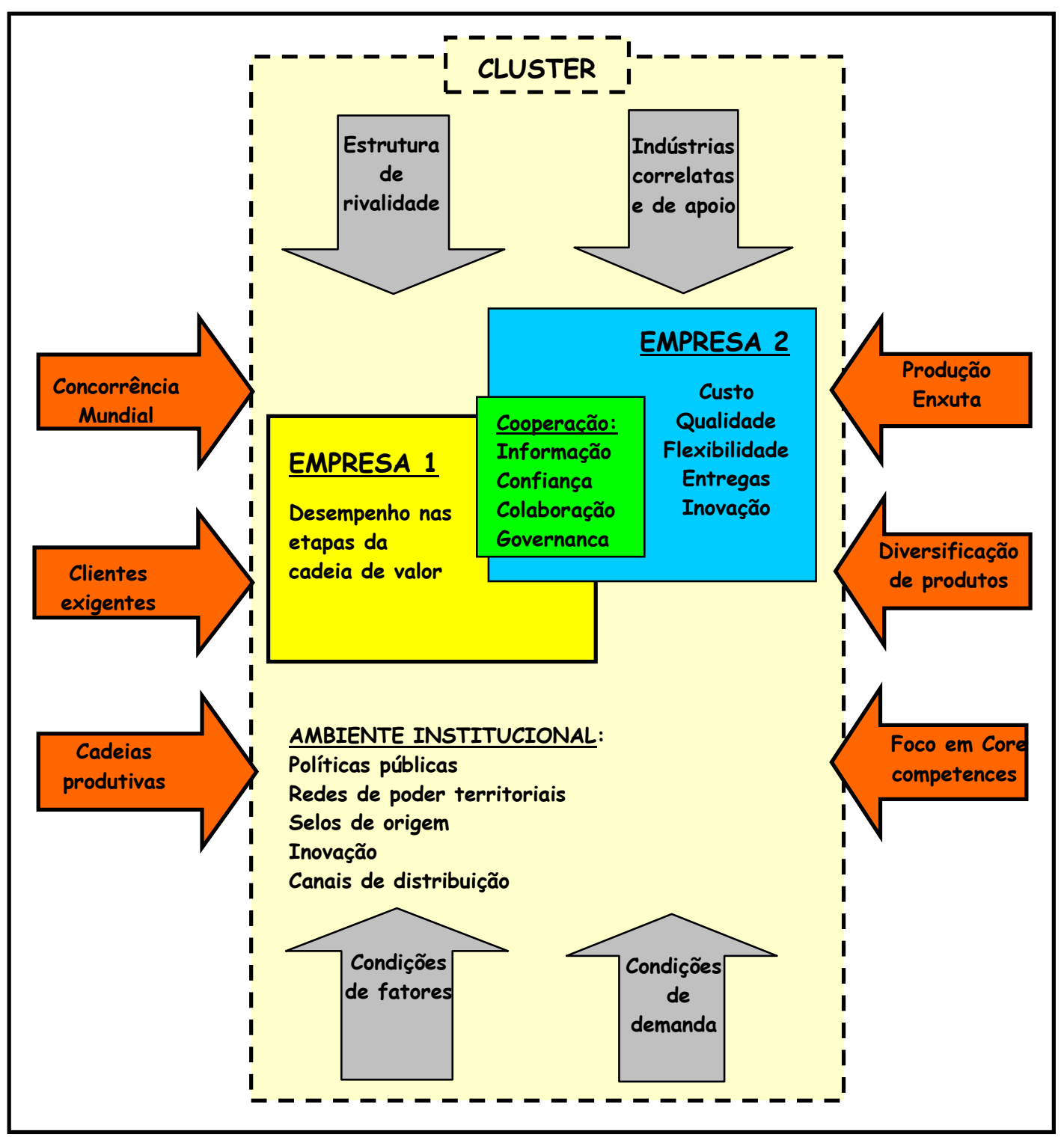

Figura 5.3: Fatores relativos à competitividade de um cluster de alimentos considerados neste trabalho: modelo geral adotado para a pesquisa.

\subsection{A pesquisa de campo}

Este tópico tem por objetivo a discussão das várias alternativas existentes para a condução de uma pesquisa científica, levando em consideração os objetivos pretendidos com a investigação. 


\subsubsection{Tipificação da pesquisa de acordo com a abordagem}

Uma pesquisa científica pode conter dois tipos fundamentais de abordagem: abordagem quantitativa e abordagem qualitativa.

A abordagem quantitativa, também chamada de pesquisa empírica ou método científico tradicional (Westbrook, 1995), parte da formulação dedutiva de uma ou mais hipóteses através de pesquisa teórica inicial, confirmando, ou não, estas hipóteses, através de observação empírica. De acordo com Bryman (1989), ao utilizar este método, o pesquisador deve se preocupar com algumas questões básicas como a replicação dos resultados encontrados e a busca de conclusões que possam ser generalizadas além dos limites da pesquisa.

Já a abordagem qualitativa busca enfatizar a perspectiva da pessoa que está sendo pesquisada, tendo as seguintes características:

- o pesquisador observa os fatos sob a ótica de alguém interno à organização;

- a pesquisa busca uma profunda compreensão do contexto da situação;

- a pesquisa enfatiza o processo dos acontecimentos, isto é, a sequiência dos fatos ao longo do tempo;

- o enfoque da pesquisa é mais desestruturado, não há hipóteses fortes no início da pesquisa. Isto confere à pesquisa bastante flexibilidade;

- a pesquisa geralmente emprega mais de uma fonte de dados (Bryman, 1989).

A Tabela 5.1 traça um comparativo entre estas duas abordagens, servindo de guia para a escolha entre uma e outra metodologia. 
TABELA 5.1: Comparativo entre as abordagens.

\begin{tabular}{|l|c|c|}
\hline \multicolumn{1}{|c|}{ Aspecto } & \multicolumn{1}{c|}{$\begin{array}{c}\text { Pesquisa } \\
\text { Quantitativa }\end{array}$} & Pesquisa qualitativa \\
\hline - $\quad \begin{array}{l}\text { Enfase na interpretação do } \\
\text { entrevistado }\end{array}$ & Menor & Maior \\
\hline - $\begin{array}{l}\text { Importância do contexto da } \\
\text { organização pesquisada }\end{array}$ & Menor & Maior \\
\hline - $\begin{array}{l}\text { Proximidade do pesquisador em relação } \\
\text { aos fenômenos estudados }\end{array}$ & Menor & Maior \\
\hline - $\quad$ Alcance do estudo no tempo & Instantâneo & Intervalo maior \\
\hline - $\quad$ Pontero de fonte de dados & Uma & Várias \\
\hline - $\quad$ Quadro teórico e hipóteses & $\begin{array}{c}\text { Interno à } \\
\text { organização }\end{array}$ \\
\hline
\end{tabular}

Fonte: Bryman (1989).

\subsubsection{Métodos e instrumentos de pesquisa}

Uma vez definida a abordagem a ser utilizada, se faz necessária a escolha do método de pesquisa bem como o instrumento de coleta de dados a serem empregados. A Tabela 5.2 relaciona de forma clara estes três conceitos: abordagem, método e instrumento de pesquisa.

TABELA 5.2: Principais métodos de pesquisa e instrumentos utilizados na EP

\begin{tabular}{|l|l|l|}
\hline \multicolumn{1}{|c|}{ Método de pesquisa } & \multicolumn{1}{|c|}{ Abordagem principal } & \multicolumn{1}{c|}{ Instrumentos } \\
\hline Experimental & Quantitativa & Experimentos \\
\hline Survey & Quantitativa & Questionários \\
\hline Estudo de caso & Qualitativa & Entrevistas e outras fontes \\
\hline Pesquisa participante & Qualitativa & Observação direta \\
\hline Pesquisa-ação & Qualitativa & Observação e participação diretas \\
\hline
\end{tabular}

Fonte: Nakano \& Fleury (1996).

A escolha por determinado método de pesquisa dependerá da capacidade do pesquisador em estabelecer ou identificar claramente o problema ou a solução que se que verificar ou conhecer. Assim, o primeiro passo para se projetar uma pesquisa é determinar qual o seu propósito. Segundo Dane (1990), Yin (1994) e Marshall \& Rossman (1995), pode-se destacar quatro propósitos básicos de investigação: exploratório, descritivo, explanatório e preditivo. Portanto, o método de pesquisa e os instrumentos utilizados para a coleta de dados devem ser escolhidos e organizados de 
acordo com o propósito de cada investigação. A Tabela 5.3 adaptada de Berto \& Nakano (1998), sintetiza e relaciona a intenção de pesquisa aos atributos que definem e condicionam os métodos e instrumentos de pesquisa adequados a cada propósito explicitado.

TABELA 5.3: Indicativos para a escolha do método de pesquisa

\begin{tabular}{|c|c|c|c|c|}
\hline $\begin{array}{l}\text { Propósito do } \\
\text { estudo }\end{array}$ & $\begin{array}{l}\text { Pergunta } \\
\text { abstrata }\end{array}$ & $\begin{array}{c}\text { Exemplos de perguntas } \\
\text { de pesquisa }\end{array}$ & $\begin{array}{l}\text { Método de } \\
\text { pesquisa }\end{array}$ & $\begin{array}{l}\text { Exemplos de } \\
\text { instrumentos } \\
\text { de coleta de } \\
\text { dados }\end{array}$ \\
\hline $\begin{array}{l}\text { EXPLORATÓRIO } \\
\text { - } \quad \text { Investigar } \\
\text { fenômenos pouco } \\
\text { compreendidos } \\
\text { - Identificar ou } \\
\text { descobrir } \\
\text { variáveis } \\
\text { importantes } \\
\text { - Gerar hipóteses } \\
\text { para pesquisa } \\
\text { futura }\end{array}$ & $\begin{array}{l}\text { O fato } \\
\text { existe? }\end{array}$ & $\begin{array}{c}\text { O que está acontecendo } \\
\text { em...? } \\
\text { Quais são os aspectos, } \\
\text { padrões e categorias } \\
\text { importantes em...? } \\
\text { Como esses padrões se } \\
\text { relacionam com outros? }\end{array}$ & $\begin{array}{c}\text { Survey } \\
\text { Estudo de caso } \\
\text { Pesquisa } \\
\text { participante }\end{array}$ & $\begin{array}{l}\text { Observação } \\
\text { direta } \\
\text { Entrevistas }\end{array}$ \\
\hline $\begin{array}{l}\text { DESCRITIVO } \\
\text { - Documentar o } \\
\text { fenômeno de } \\
\text { interesse }\end{array}$ & $\begin{array}{l}\text { O que é o } \\
\text { fato? } \\
\text { Como ele é } \\
\text { diferente } \\
\text { de outros? }\end{array}$ & $\begin{array}{c}\text { Quais são os } \\
\text { comportamentos, eventos, } \\
\text { crenças, estruturas, atitudes } \\
\text { e processos que ocorrem } \\
\text { nesse fenômeno? }\end{array}$ & $\begin{array}{c}\text { Survey } \\
\text { Pesquisa } \\
\text { participante } \\
\text { Estudo de caso } \\
\text { Etnografia }\end{array}$ & $\begin{array}{l}\text { Observação } \\
\text { direta } \\
\text { Entrevistas } \\
\text { Análise } \\
\text { documental } \\
\text { Questionários }\end{array}$ \\
\hline $\begin{array}{l}\text { EXPLANATÓRIO } \\
\text { - Explicar as } \\
\text { forças que } \\
\text { causam o } \\
\text { fenômeno } \\
\text { - Identificar os } \\
\text { possíveis } \\
\text { conjuntos de } \\
\text { causas que } \\
\text { determinam o } \\
\text { fenômeno } \\
\end{array}$ & $\begin{array}{c}\text { O que causa } \\
\text { o fato? }\end{array}$ & $\begin{array}{c}\text { Que eventos, crenças, } \\
\text { políticas estão determinando } \\
\text { esse fenômeno? } \\
\text { Como essas forças interagem } \\
\text { para determinar esse } \\
\text { fenômeno? }\end{array}$ & $\begin{array}{c}\text { Survey } \\
\text { Estudo de caso } \\
\text { Múltiplo } \\
\text { Estudo } \\
\text { histórico } \\
\text { Pesquisa } \\
\text { participante } \\
\text { Etnografia }\end{array}$ & $\begin{array}{l}\text { Observação } \\
\text { direta } \\
\text { Entrevistas } \\
\text { Questionários } \\
\text { Análise } \\
\text { documental }\end{array}$ \\
\hline $\begin{array}{l}\text { PREDITIVO } \\
\text { - } \quad \text { Predizer o } \\
\text { resultado de um } \\
\text { fenômeno. } \\
\text { - } \quad \text { Prever os } \\
\text { eventos e } \\
\text { comportamentos } \\
\text { resultantes de } \\
\text { um fenômeno. }\end{array}$ & $\begin{array}{c}\text { Como o fato } \\
\text { é } \\
\text { relacionado } \\
\text { com outros? }\end{array}$ & $\begin{array}{c}\text { O que vai acontecer como } \\
\text { resultado desse fenômeno? } \\
\text { Quem será afetado? } \\
\text { De que forma? }\end{array}$ & $\begin{array}{c}\text { Survey } \\
\text { Pesquisa-ação } \\
\text { Experimentos }\end{array}$ & $\begin{array}{l}\text { Questionários } \\
\text { (grande } \\
\text { escala) } \\
\text { Observação } \\
\text { direta }\end{array}$ \\
\hline
\end{tabular}

Fonte: Berto \& Nakano (1998). 


\subsubsection{Projeto metodológico}

O projeto metodológico consiste em selecionar a abordagem e o método de pesquisa mais adequado para a execução da referida pesquisa e, a partir daí, decidir quais instrumentos serão empregados para a coleta dos dados. Para tanto, são necessários a seleção da abordagem e o conhecimento das características e da questão central da pesquisa.

A caracterização da pesquisa é um ponto fundamental na correta seleção do método de pesquisa que será adotado. A pesquisa pode ser caracterizada por:

- Objetivo principal.

- $\quad$ Fase de desenvolvimento do assunto.

- Condições de manipulação do objeto de estudo.

- Variáveis de interesse.

A questão de pesquisa não é uma hipótese a ser testada. Ela é o ponto de partida e garantia de foco para a pesquisa de campo ser realizada. Segundo Yin (1994), a definição da questão de pesquisa é provavelmente o passo mais importante a ser tomado em uma pesquisa e o autor recomenda que seja dedicado a ela um tempo de reflexão.

A resposta à questão de pesquisa gerará uma hipótese geral e a partir daí um conjunto de proposições que além de refletir uma questão teórica começará a dizer onde procurar evidências relevantes (Yin, 1994). O conjunto de proposições expressa o entendimento do assunto que o pesquisador tem sobre o tema de pesquisa antes de iniciar o trabalho de campo. Geralmente o conjunto de proposições é originado de uma reflexão da revisão da literatura. Após a pesquisa, o conjunto de proposições será revisto. 


\subsection{Metodologia de pesquisa utilizada neste trabalho}

\subsubsection{Objetivo da pesquisa}

Perante o contexto agroindustrial contemporâneo, este trabalho tem por objetivo a caracterização e a análise do cluster alimentício da cidade de Marília/SP, visando conhecer seus principais aspectos estruturais e infra-estruturais para posterior análise tanto da sua competitividade e quanto da competitividade das micro e pequenas empresas que nele se inserem.

\section{* Objetivo secundário:}

Tendo como pano de fundo a análise competitiva realizada na etapa anterior, tem-se como objetivo secundário a elaboração das ações que podem ser realizadas para o aumento do poder competitivo das MPE's que compõem o referido cluster.

\subsubsection{Questão da pesquisa:}

"Perante os fatores que definem a competitividade para o segmento estudado (micro e pequenas empresas do ramo alimentício presente em um cluster), como este cluster está configurado no que se refere à competitividade das MPE's que o compõe?

\subsubsection{Hipótese:}

Para o estudo da competitividade de um cluster é possível elencar 3 níveis para que seja efetuada sua análise: nível interno às empresas, nível relacionado aos aspectos ligados à cooperação entre as empresas do cluster e nível externo às empresas (ambiente institucional). Além destes, destaca-se a análise da relação existente entre os elementos presentes em cada um deste 3 níveis. 


\subsubsection{Proposições:}

* As MPE's presentes no cluster alimentício de Marília possuem baixos níveis de cooperação entre si, devido a dois fatores principais: falta de confiança existente entre as empresas e falta de informação a respeito dos reais benefícios da cooperação,

* A ausência da cooperação entre as empresas do cluster afeta negativamente a competitividade das mesmas. Esta diminuição de competitividade se acentua pela baixa capacidade de inovação destas empresas em termos de produto, processo e de gestão.

* As MPE's presentes no cluster alimentício de Marília carecem de recursos de poder essenciais para a definição de sua competitividade, devido à assimetria de poder existente entre estas empresas e os demais atores do ambiente institucional (empresas de médio e grande porte, sindicatos, prefeitura, associações,...). Dentre estes recursos de poder destacam-se especialmente a informação, o acesso a canais de distribuição e a obtenção de uma marca forte.

* De acordo com as proposições anteriores, os critérios (fatores) indispensáveis para a competitividade destas empresas estão definidos por aspectos internos às empresas (estruturais e infra-estruturais) e por aspectos presentes no ambiente institucional (ambiente externo) no qual estas empresas se inserem (o cluster). Os pontos que caracterizam a cooperação existente entre as empresas também se constituem fatores que podem definir a competitividade.

\subsubsection{Seleção da abordagem e método de pesquisa}

\subsubsection{Etapa 1}

Para a execução desta pesquisa foi necessário dividi-la em duas partes. Em um momento inicial foi realizada uma coleta de dados para a caracterização e 
quantificação da indústria alimentícia na cidade. Para a caracterização destas empresas foram levantados alguns dados de natureza qualitativa. Dados quantitativos como número de empresas, quantidade de funcionários, linhas de produtos fabricados também foram coletados. Para efeitos práticos, esta etapa é denominada de Etapa 1 da pesquisa.

Nesta etapa também foram identificadas as entidades que compõem o tecido institucional do cluster em questão.

Desse modo, a abordagem adotada nesta Etapa 1 é tanto quantitativa como qualitativa, com a utilização do método de pesquisa survey, e o instrumento para a coleta de dados utilizado são entrevistas com a utilização de um roteiro estruturado, com a predominância de respostas abertas (ANEXO I). A tabela 5.4 resume a alternativa metodológica adotada nesta parte da pesquisa.

De acordo com Nakano \& Fleury (1996), o survey tem por objetivo a coleta de dados através de entrevista ou questionário projetados para esta finalidade, não havendo, porém, intervenção do pesquisador. $\mathrm{O}$ resultado exprime um instantâneo de práticas e atitudes de um determinado grupo em um ponto no tempo, sendo que a análise dos dados coletados exige tratamento estatístico. Pelo exposto, este método mostrou-se bastante adequado para o objetivo desta primeira etapa da pesquisa.

TABELA 5.4: Resumo do projeto metodológico da pesquisa (Etapa 1)

\section{Etapa I}

Objeto de estudo: empresas processadoras de alimentos do município de Marília/SP.

\begin{tabular}{|c|c|}
\hline Abordagem & Quantitativa e Qualitativa \\
\hline Propósito do estudo & Descritivo e Exploratório \\
\hline Método de pesquisa & Survey \\
\hline Instrumentos de coleta de dados & Entrevistas com utilização de roteiro estruturado \\
\hline Unidades de análise & $\begin{array}{l}100 \% \text { das empresas processadoras de alimentos } \\
\text { identificadas. }\end{array}$ \\
\hline Objetivo principal da etapa & $\begin{array}{l}\text { Conhecer alguns aspectos quantitativos e } \\
\text { qualitativos gerais que caracterizam as empresas } \\
\text { do conjunto. } \\
\text { Conhecer quais as principais entidades que } \\
\text { compõem o tecido institucional do cluster. }\end{array}$ \\
\hline
\end{tabular}




\section{- Critérios adotados na Etapa 1 da pesquisa}

Para o estudo do cluster em questão, foi necessário, em um primeiro momento, o levantamento das empresas de alimentos da cidade de Marília.

De acordo com a proposta de segmentação de Batalha \& Silva (2001) ${ }^{1}$, esta pesquisa teve a preocupação de limitar o estudo ao macrosegmento “industrialização", pesquisando apenas as empresas manufatureiras, ou seja, empresas efetivamente processadoras de alimentos. Assim, foi utilizado o critério de analisar empresas produtoras cujas vendas transcendam o local de produção. Foram excluídas, desta forma, empresas que possuem como seu único ponto de venda o balcão, como é o caso de padarias, restaurantes, e outros pequenos estabelecimentos, além de empresas exclusivamente distribuidoras ou embaladoras de produtos. Acredita-se que a análise detalhada da cadeia de fornecimentos das empresas produtoras encontradas abrirá caminhos para pesquisas posteriores, cujo enfoque esteja especificamente na análise das demais atividades da cadeia (como distribuidores e empresas de embalagens, por exemplo).

Uma primeira limitação encontrada nesta etapa foi com relação à exatidão de dados relativos à quantidade de empresas alimentícias existentes na cidade de Marília, bem como ao porte e às linhas de produtos fabricados pelas mesmas. Apesar de várias entidades de classe locais (Tabela 5.5) possuírem listagens atualizadas a respeito das firmas a elas associadas, era inexistente na cidade uma listagem única, contendo informações cadastrais destas empresas. Desta forma, a alternativa encontrada foi a realização de um cruzamento de informações das listagens oferecidas pela referidas entidades, chegando a um total de 58 empresas identificadas e 55 efetivamente pesquisadas.

Dada a abrangência das questões desta etapa da pesquisa, para garantir que houvesse fidelidade nas respostas foram entrevistados funcionários das empresas que ocupassem pelo menos o nível gerencial dentro de suas estruturas.

\footnotetext{
${ }^{1}$ Para maiores detalhes sobre este critério, consultar item 2.1 deste trabalho.
} 
TABELA 5.5: Entidades fornecedoras das listagens das empresas de alimentos de Marília

\begin{tabular}{|l|}
\hline \multicolumn{1}{|c|}{ Entidade } \\
\hline Associação Comercial e Industrial de Marília (ACIM) \\
\hline Junta Comercial de Marília \\
\hline Associação das empresas alimentícias de Marília (ADIMA) \\
\hline April Fest \\
\hline ADIRA \\
\hline CETESB \\
\hline Prefeitura Municipal de Marília - cadastro de empresas \\
\hline
\end{tabular}

\subsubsection{Etapa 2}

Neste segundo momento, os dados coletados são de natureza qualitativa, uma vez que os parâmetros coletados para a elaboração desta etapa tratam-se de variáveis de natureza complexa e descritiva e, desta forma, difíceis de serem captados em toda sua abrangência por métodos meramente quantitativos.

Ressalta-se, no entanto, que a Etapa 2 desta pesquisa também se compõe de duas partes. Na primeira parte (Parte A) foi entrevistada pelo menos uma pessoa do nível estratégico das micro e pequenas empresas da cidade, com o intuito de realizar um levantamento das principais características destas empresas com relação a seus aspectos estruturais e infra-estruturais bem como o seu relacionamento com as outras empresas do setor presentes na cidade e com as entidades de classe locais.

Na segunda parte (Parte B) foram entrevistados representantes de entidades do ambiente institucional em que estas empresas se inserem, como sindicatos, prefeitura, associações, entre outros. Aqui foi utilizado um roteiro aberto, onde não há a limitação das possibilidades de respostas a grupos pré-estabelecidos.

As Tabelas 5.6 e 5.7 resumem as alternativas metodológicas adotadas para a pesquisa nestas duas partes as Etapa 2. 
TABELA 5.6: Resumo do projeto metodológico da pesquisa (Etapa 2 - Parte A)

\begin{tabular}{|c|c|}
\hline \multicolumn{2}{|c|}{$\begin{array}{c}\text { Etapa 2: Parte A } \\
\text { Objeto de estudo: MPE's }\end{array}$} \\
\hline Abordagem & Qualitativa \\
\hline Propósito do estudo & Exploratório \\
\hline Método de pesquisa & Estudo de caso \\
\hline Instrumentos de coleta de dados & Entrevistas com a utilização de roteiro estruturado \\
\hline Unidades de análise & Amostra representativa de MPE's \\
\hline Objetivo principal da etapa & $\begin{array}{l}\text { Conhecer a situação das MPE's com relação a } \\
\text { aspectos estruturais (certificações, ferramentas de } \\
\text { gestão utilizadas, formação dos funcionários, etc) } \\
\text { quanto infra-estruturais (idade do maquinário, } \\
\text { tecnologia utilizada na fabricação, etc) e sua relação } \\
\text { com outras empresas do cluster (fornecedores e } \\
\text { concorrentes). }\end{array}$ \\
\hline
\end{tabular}

TABELA 5.7: Resumo do projeto metodológico da pesquisa (Etapa 2 - Parte B)

\begin{tabular}{|c|c|}
\hline \multicolumn{2}{|c|}{$\begin{array}{l}\text { Etapa 2: Parte B } \\
\text { estudo: Ambiente Institucional }\end{array}$} \\
\hline Abordagem & Qualitativa \\
\hline Propósito do estudo & Descritivo e Exploratório \\
\hline Método de pesquisa & Estudo de caso \\
\hline Instrumentos de coleta de dados & Entrevistas com utilização de roteiro estruturado \\
\hline Unidades de análise & $\begin{array}{ll}\text { - } & \text { Secretaria da ind. e comércio } \\
\text { - } & \text { ADIMA } \\
\text { - } & \text { Gead } \\
\text { - } & \text { Sindicato dos trab. da ind. alimentícia } \\
\text { - } & \text { Sesi, Senai, Sebrae } \\
\text { - } & \text { Ciesp }\end{array}$ \\
\hline Objetivo principal da etapa & $\begin{array}{l}\text { Conhecer o ambiente institucional no qual as } \\
\text { empresas estão inseridas, com o objetivo de delinear } \\
\text { as principais ações das instituições deste ambiente e } \\
\text { seu reflexo para as MPE's. } \\
\text { Conhecer a rede de poder que governa este } \\
\text { ambiente e a situação (posicionamento) das MPE's } \\
\text { nesta relação. }\end{array}$ \\
\hline
\end{tabular}

Assim, o estudo de casos aqui discutido utiliza-se de um método qualitativo de pesquisa descritiva exploratória. Um método qualitativo é empregado em casos onde a riqueza dos detalhes é mais relevante do que as informações quantitativas (Richardson, 1984), como é o caso desta investigação. A pesquisa descritiva exploratória, por sua vez, designa situações onde a pesquisa é realizada por meio de 
observações, registros, análise e correlações de dados em situações onde há poucos conhecimentos sobre o assunto estudado (Cervo \& Bervian, 1983).

Esse método, segundo Cervo \& Bervian (1983), possui a vantagem de possibilitar a descoberta de características novas em relação ao tema estudado. Porém, sua utilização deve ser realizada com cuidado, uma vez que as conclusões alcançadas se particularizam para a população estudada, não permitindo generalizações.

A seguir são apresentados os critérios para a definição do método, que foram estabelecidos com base em Yin (1994), a partir das características da pesquisa. Essas características são:

- necessidade da presença do pesquisador para garantir a correta interpretação, por parte dos entrevistados, dos conceitos envolvidos;

- variáveis de difícil mensuração, que torna a abordagem de pesquisa qualitativa mais adequada e o método estudo de caso uma possibilidade;

- contribuição para o entendimento das relações os itens a serem levantados e, indiretamente, os critérios que definidores da competitividade. Isso leva ao método de estudo de caso como o mais adequado;

- procura pela resposta à pergunta "como se dá", confirmando a adequação ao método estudo de caso;

- generalização dos resultados encontrados somente na forma analítica.

\section{- Critérios adotados na Etapa 2 da pesquisa:}

As entrevistas realizadas nesta etapa da pesquisa se limitam a uma amostra de empresas. Para se obter uma amostra representativa das empresas do município as mesmas foram divididas de acordo com o critério linha de produtos fabricados. Desta maneira, o total de linhas de produtos fabricados pelas empresas do conjunto foi agrupado em 5 grandes linhas e de cada uma dessas foram, então, entrevistadas duas empresas: uma de micro e outra de pequeno porte, obedecendo o critério número de funcionários. $\mathrm{O}$ agrupamento das linhas de produto foi o seguinte: confeitos; biscoitos doces, salgados, recheados e de polvilho; balas, doces, gomas, pirulitos, e mel e derivados; salgadinhos de trigo, massas e salgados; e um grupo geral, 
denominado de "outros", que inclui achocolatados, molhos e temperos e leite e seus derivados.

Conforme já discutido nos capítulos anteriores, a competitividade de uma empresa se dá devido a fatores internos (competitividade empresarial) e externos às organizações (competitividade regional). Além disso, por se tratar de um cluster, o fator cooperação entre empresas passa a ter muita relevância na capacidade competitiva deste conjunto.

A revisão bibliográfica realizada (sintetizada pela Figura 5.1) auxiliou na definição de um elenco de fatores que podem ser úteis para a dinamização da competitividade, específicos para as características encontradas no objeto de estudo. Estima-se que a adoção destes fatores ajudará a alavancar a competitividade das empresas do cluster (competitividade empresarial) e, consequentemente, a competitividade do cluster como um todo (competitividade regional). Desta forma, o critério adotado para este estudo obedece a lógica proposta na Figura 5.1.

\section{* Fatores Internos}

A análise do ambiente interno às empresas aqui realizada tem por finalidade principal a compreensão de algumas características básicas que norteiam estas empresas com relação à condução de seus negócios. O objetivo desta análise, portanto, não se constitui em realizar um estudo exaustivo, mas a obtenção de um panorama geral de como estas empresas estão sendo administradas para que se possa, posteriormente, traçar o perfil competitivo destas empresas com relação ao mercado em que operam.

Para a estruturação desta etapa da pesquisa foi utilizado o conceito de "cadeia de valor" de Porter (1990). A opção por este conceito se deve, principalmente, ao fato de se tratar de uma visão ampla, abordando de uma maneira geral todas as operações de uma empresa.

O uso da "cadeia de valor" para a referida análise também possui uma outra razão importante. Segundo o argumentado por Cassarotto Filho \& Pires (1999), as empresas de menor porte possuem dificuldades em dominar todas as etapas da cadeia. Assim, uma análise a partir deste conceito também permitirá a descoberta de 
pontos fracos que podem ser suprimidos pelo compartilhamento de recursos com outras empresas.

Ressalta-se que para atingir os critérios de desempenho definidos a partir das exigências do mercado, uma empresa necessita possuir estrutura e infra-estrutura tal que a permita produzir com qualidade, possuir programa de redução de custos, desempenho adequado nas entregas e flexibilidade e inovação para atender às variações na demanda.

A figura 5.4 apresenta a cadeia de valor genérica complementada pelas visões de Cassaroto Filho \& Pires (1999) e Longenecker et al. (1998), utilizada por este trabalho.

\begin{tabular}{|c|c|c|c|c|c|}
\hline $\begin{array}{l}\text { Infra- } \\
\text { estrutura: }\end{array}$ & \multicolumn{5}{|c|}{ A. Tecnologia de Gestão: RH, Qualidade, Planejamento, Gestão Financeira } \\
\hline $\begin{array}{c}\text { B. } \\
\text { Operação } \\
\text { (Atividades } \\
\text { primárias) }\end{array}$ & $\begin{array}{l}\text { Atualização } \\
\text { setorial } \\
\text { Desenvolvimen } \\
\text { to de produtos } \\
\text { Tecnologia de } \\
\text { processos }\end{array}$ & $\begin{array}{l}\text { Logística de } \\
\text { Aquisições } \\
\text { Compras } \\
\text { Estocagem de } \\
\text { materiais } \\
\text { Transporte } \\
\text { de materiais }\end{array}$ & \begin{tabular}{l}
\multicolumn{1}{c}{ Produção } \\
\\
Produção interna \\
Custos \\
Flexibilidade \\
Logística de \\
produção \\
Produção \\
externa
\end{tabular} & $\begin{array}{l}\text { Logística de } \\
\text { Distribuição } \\
\text { Estocagem de } \\
\text { produtos } \\
\text { Transporte } \\
\text { de produtos } \\
\text { Redes de } \\
\text { distribuição }\end{array}$ & $\begin{array}{l}\text { Marketing } \\
\text { Atualização } \\
\text { setorial } \\
\text { Marca } \\
\text { Vendas } \\
\text { Atendimento } \\
\text { Assistência }\end{array}$ \\
\hline
\end{tabular}

Figura 5.4: Atividades da cadeia de valor utilizadas neste trabalho para a análise interna das empresas. Fonte: Casarotto Filho \& Pires, 1999.

Desta maneira, é apresentada na seqüência a estrutura de tópicos adotada para a análise. Uma breve explanação da importância de cada um dos conceitos abordados é exposta junto a cada tópico, além da seleção da natureza de questões a serem investigadas em cada um deles. 


\section{A. Tecnologia de Gestão (atividades de suporte às demais):}

\section{Planejamento}

O planejamento de uma empresa consiste no processo gerencial de desenvolver e manter uma direção estratégica que alinhe as metas e os recursos da organização com suas mutantes oportunidades do mercado (Kotler \& Bloom, 1988).

Como produto principal do processo de planejamento está a estratégia da empresa, que define os seus objetivos para um determinado período de tempo, bem como a necessidade de recursos para alcançá-los.

O planejamento de uma empresa pode ser formal ou informal. Quando formalizado, há a ampla divulgação dos objetivos da empresa para todos os seus membros e um conseqüente aumento do comprometimento de todos na organização. Quando informal, há o risco de não se cumprirem as metas estabelecidas.

\footnotetext{
$\checkmark \quad$ Existência de estratégia formal

$\checkmark \quad$ Estratégia adotada pela empresa

$\checkmark \quad$ Modo como são obtidas informações para a definição da estratégia

$\checkmark \quad$ Maneira como são direcionadas as estratégias de mercado.
}

\section{Recursos Humanos}

Contratar as pessoas certas e obter seu desempenho motivado são fatores essenciais para atingir o potencial de qualquer negócio. Desta maneira, o recrutamento e a seleção de funcionários, bem como o seu treinamento e desenvolvimento se constituem em fatores-chave para a o sucesso de uma organização (Longenecker et al., 1998). Além disso, sistemas de incentivos como a participação nos lucros da empresa ou benefícios como cestas básicas e plano de saúde também se constituem em boas fontes de motivação para os colaboradores da empresa. 
Sendo assim, a política de gerenciamento de Recursos Humanos adotada pela empresa pode refletir um pouco a maneira como a empresa conduz e valoriza seus funcionários.

\footnotetext{
$\checkmark \quad$ Forma como se dá a contratação de funcionários

$\checkmark \quad$ Como são as estratégias de Gestão de RH?

$\checkmark \quad$ Como o treinamento tem sido aplicado?

$\checkmark \quad$ Benefícios cedidos aos funcionários.
}

\section{Administracão da Qualidade}

Ao longo do tempo, o conceito de qualidade foi se expandindo, acompanhando a própria evolução dos sistemas produtivos. Inicialmente, o conceito de qualidade centrava-se no produto, e, assim, o conceito de qualidade mais se associava à conformidade física do produto. Assim, as eras da Inspeção (análise de 100\% dos produtos acabados) e do Controle Estatístico (análise por amostragens dos produtos produzidos) centrava-se na premissa de controlar as características físicas dos produtos produzidos. Com a evolução dos conceitos administrativos, o entendimento do conceito de qualidade se expandiu para um conceito mais abrangente, onde ter produtos de qualidade significa atender os clientes em suas exigências e promover a sua satisfação. Esta era da qualidade, também chamada de era da Qualidade Total, entende que, para alcançar a satisfação dos clientes é importante que todos da empresa possuam comprometimento com a qualidade de seus produtos. Esta filosofia tem como premissa, portanto, que todas as partes da empresa estão envolvidas neste processo de satisfação, desde a aquisição de materiais até a entrega do produto ao cliente, passando por sua produção bem como pelos serviços pós-venda.

Desta maneira, assegurar a qualidade ao cliente passa a significar um trabalho que abrange toda a organização, envolvendo um sistema, oportunamente chamado de Sistema da Qualidade.

Uso de técnicas gerenciais voltadas para a qualidade Aceitação da norma ISO 9000 
Como é executado o CQ na produção?

\section{Gestão Financeira}

A gestão financeira de uma empresa se constitui em uma das funções mais importantes, principalmente no que tange a forma em que ela capta e administra os seus recursos financeiros. Desta maneira este trabalho contempla as seguintes questões:

\section{$\checkmark \quad$ Como são escolhidas as estratégias de financiamento? \\ $\checkmark \quad$ Como as empresas administram seu capital de giro?}

\section{B. Atividades primárias}

\section{Pesquisa e desenvolvimento}

Investimentos em pesquisa e desenvolvimento de novos produtos leva a empresa a ter mais facilidade em inovar e, com isso, atender aos anseios de seus clientes. Dessa maneira, a investigação de como estas empresas desenvolvem e inovam seus produtos passa a ser importante em tempos de concorrência acirrada.

\footnotetext{
$\checkmark \quad$ A empresa realiza P\&D?

$\checkmark \quad$ A quanto tempo foi lançado o último produto da empresa?
$\checkmark$ Como têm sido efetuados os investimentos para a melhoria da competitividade?

\section{Logística de aquisicões}

Comprar a preço justo e de fontes seguras quanto à qualidade e ao prazo de entrega são quesitos muito importantes para que uma empresa assegure a sua qualidade e honre os seus compromissos. 
Assim, a seleção de fornecedores e a sua qualificação perante seu desempenho, além da confiança depositada nos mesmos em fatores importantes para assegurar o bom desempenho da empresa nesta era de estoques reduzidos e produção enxuta.

\footnotetext{
$\checkmark \quad$ Orientação das estratégias de compras

$\checkmark \quad$ Relação com os fornecedores no desenvolvimento de novos produtos

$\checkmark \quad$ Aporte de matérias-primas

$\checkmark \quad$ Programas de apoio / parcerias com os fornecedores.
}

\section{Producão}

Com a revalorização do papel estratégico da manufatura vivenciada a partir da década de 70, as questões relativas à produção passaram a ter um destaque bastante significativo para as empresas processadoras. Investimentos no setor produtivo e na melhoria das condições gerais de produção são de suma importância estratégica para empresas processadoras.

\footnotetext{
$\checkmark \quad$ Sistema de produção adotado

$\checkmark \quad$ Forma de definição dos postos de trabalho.
}

\section{Logística de distribuicão}

O acesso a canais de distribuição e a maneira como são entregues os produtos aos clientes são aqui abordados. Como já discutido na revisão bibliográfica deste trabalho, alguns segmentos da indústria de alimentos possuem estreita necessidade de pontos de vendas como bares, restaurantes e supermercados para expor e comercializar seus produtos. Desta forma, aqui são abordadas as seguintes questões:

\footnotetext{
$\checkmark \quad$ Tipo de canal de distribuição utilizado

$\checkmark \quad$ Destino das vendas (atacado/varejo)

$\checkmark \quad$ Presença de intermediários

$\checkmark \quad$ Frota utilizada para a distribuição dos produtos aos clientes
} 


\section{Marketing}

A maneira como a empresa analisa seus mercados e divulga seus produtos é aqui analisada. O conhecimento do mercado em que se atua e a promoção de produtos são fundamentais para a empresa sobreviver no mercado.
$\checkmark \quad$ Como são direcionadas as estratégias de produto?
$\checkmark \quad$ Como são realizadas as propagandas?
$\checkmark \quad$ Como são efetuados os estudos do mercado?
$\checkmark \quad$ Utilização do slogan "Marília capital do alimento".

\section{* Fatores relacionados à cooperação entre empresa do cluster}

Como foi visto na revisão bibliográfica realizada neste trabalho, uma das grandes vantagens da cooperação entre as empresas presentes no cluster é permitir que as etapas da cadeia de valor que não podem ser desempenhadas por uma empresa sozinha, possam ser realizadas por um conjunto de empresas, através da formação de consórcios. Estes consórcios podem se dar para a aquisição de matérias-primas, para a distribuição, ou até mesmo para a complementação de etapas do processo produtivo.

Para tanto, os fatores que auxiliam na formação de redes de cooperação (também chamadas de redes verticais) robustas entre empresas são:

1. Informacão: antes de tudo, as empresas precisam estar informadas sobre a possibilidade da formação de redes de cooperação entre si;

2. Confianca: esta se constitui na base para qualquer forma de cooperação. Sua ausência determina o fracasso nas tentativas de cooperação inter-empresarial;

3. Colaboracão: a prática da cooperação possui sua representação na colaboração entre todos os membros de uma rede;

4. Estrutura de Governanca: conjunto de regras formais e informais que regem a cooperação. 
Portanto, a análise da disposição das empresas em participar de redes de cooperação passa pelo pressuposto de que elas conheçam os reais benefícios da cooperação. Uma vez conhecidas estas vantagens, as empresas têm que estar dispostas à colaboração, que se dá, sobretudo, calcada na confiança existente entre as empresas do cluster.

Os fatores internos bem como os fatores de cooperação aqui discutidos foram analisados nas empresas através de roteiro demonstrado no Anexo II deste trabalho.

\section{* Fatores Externos}

Os fatores externos às empresas relacionados à competitividade das firmas do cluster de alimentos selecionados por este trabalho são:

1. Redes de poder territoriais: o ponto principal está relacionado à simetria de poder existente entre as empresas que constituem o cluster. Quanto mais simétrica for a distribuição de poder, maiores os reflexos positivos na competitividade do conjunto.

2. Políticas públicas: estas se constituem como reflexo direto da simetria de poder. Para favorecer a competitividade do conjunto, elas devem ser elaboradas de maneira a apoiar as MPE's.

3. Selo de origem: a existência de uma marca forte relacionada ao cluster. O estímulo à adoção formal de um selo de origem que caracterize as empresas presentes no aglomerado se constitui em uma maneira de projetar o cluster como um todo.

4. Inovacão : o auxílio de centros de pesquisa/universidades passa a ser fundamental para alavancar a competitividade, sobretudo das MPE's, que, na maioria das vezes, não contam com capacidade para a realização de pesquisa e desenvolvimento, tanto de produtos quanto de processo. Além disso, muitas vezes estas empresas carecem de conhecimento acerca de ferramentas gerenciais a serem adotadas para a melhoria de seus sistemas de gestão.

5. Canais de distribuicão: relacionado a como o cluster está preparado para articular às suas empresas o acesso a novos clientes (canais de distribuição). 
6. Estratégia e estrutura de rivalidade: como se dá a relação entre as empresas concorrentes presentes no mesmo ambiente. Segundo Porter (1991), a rivalidade entre concorrentes é importante o estímulo do crescimento das empresas. Ressalta-se, porém, que uma estrutura de rivalidade muito acirrada pode vir a comprometer a formação de redes de cooperação entre as mesmas.

7. Indústrias correlatas e de apoio: este se constitui em um fator importante para a definição da competitividade de uma dada região. A presença de empresas fornecedoras de matérias-primas e de embalagens, de empresas de manutenção e de laboratórios especializados, por exemplo, complementam as atividades das empresas do cluster, uma vez que as mesmas terão o atendimento de suas necessidades proporcionado por empresas presentes no mesmo ambiente. Este fator pode levar à redução de custos com fretes, por exemplo, além de possibilitar a redução no tempo de atendimento de uma necessidade.

8. Condiç̃oes de fatores: fatores relacionados à infra-estrutura do cluster são aqui considerados, como localização, estrutura viária de acesso aos grandes centros consumidores, além de condições das redes de água e esgoto, entre outros.

9. Condicões de demanda: o quanto o local tem condições de absorver a produção originada pelas empresas do cluster.

Ressalta-se que, devido às limitações encontradas na colaboração por parte de algumas entidades presentes no município, nem todas as entidades identificadas foram pesquisadas. Porém, este fator não se constituiu em prejuízos para a pesquisa, uma vez que os dados necessários para a análise dos fatores externos foram conseguidos pelas entidades que efetivamente colaboraram com este trabalho. Nesta parte da pesquisa foram, então, entrevistados representantes das seguintes entidades: ADIMA, SEBRAE, Secretaria da Indústria e Comércio, SESI e Fundação de Ensino "Eurípides Soares da Rocha". 


\section{SÍNTESE DO CAPÍTULO}

Este capítulo teve como objetivo principal a definição da metodologia de pesquisa adotada por este trabalho. Em um primeiro momento foi apresentada uma síntese da revisão bibliográfica, cujos conceitos originou o modelo geral adotado por esta pesquisa.

Na seqüência, foram abordadas as diversas possibilidades metodológicas para a execução de uma pesquisa e, por fim, foi apresentada a alternativa metodológica adotada.

O próximo capítulo trata, então, da apresentação e análise dos dados coletados nas duas etapas da pesquisa de campo realizada. 


\section{ANÁLISE DO CLUSTER ALIMENTÍCIO DE MARÍLIA/SP}

Este capítulo tem por objetivo a apresentação e a análise dos resultados da pesquisa realizada nas MPE's processadoras de alimentos e nas entidades do tecido institucional do cluster alimentício do município de Marília/SP. Desta maneira, inicialmente são apresentadas algumas considerações gerais sobre os pontos que caracterizam o cluster, coletados na Etapa 1 da pesquisa (caracterização do cluster alimentício), tais como número de empresas, empregos gerados, entre outros, visando fornecer alguns dados gerais do cluster em questão.

Num segundo momento são apresentados e analisados os dados referentes à segunda etapa da pesquisa (Etapa 2), objetivando a análise da competitividade do cluster, através da compreensão dos fatores internos (competitividade das empresas) e dos fatores relacionados à cooperação entre suas MPE's, além dos fatores externos às organizações (competitividade regional).

E, por fim, é descrito o panorama competitivo geral do referido cluster e são propostas algumas ações para a dinamização de sua competitividade.

\subsection{Etapa I: a cidade de Marília como um cluster alimentício}

Os tópicos a seguir tratam especificamente de mostrar os dados coletados nesta Etapa 1 da pesquisa de campo - caracterização do cluster.

\subsubsection{Aspectos gerais}

Algumas cidades do interior paulista têm se utilizado das vantagens oferecidas pelos clusters para se destacarem, ganhando escala e projeção no mercado nacional e internacional. Como exemplos de sucesso cita-se o setor calçadista, destacando-se as cidades de Franca, Jaú e Birigui. Já no setor de cerâmicas, destacam-se as cidades de 
Porto Ferreira, Jardinópolis e Itu e no setor de móveis as cidades de Votuporanga e Itatiba (Amato Neto, 1999).

No setor de alimentos, destaca-se a cidade de Marília, sendo que o foco principal da maior parte das empresas deste município concentra-se no segmento de alimentos processados. O município acolhe importantes empresas do ramo alimentício tais como a Nestlé, Coca-Cola, Marilan, Bel, Xereta e Dori, além de inúmeras outras pequenas empresas do ramo, com uma produção mensal de 30.000 toneladas de alimentos por mês (Adima, 2003). Dentre os principais produtos que este grupo de empresas fabrica ressalta-se a produção de biscoitos, balas e doces, cujos produtos destinam-se principalmente ao mercado regional e nacional. Há também uma pequena parcela de empresas que destina parte de sua produção para exportação, com destaque para o Mercosul, Estados Unidos e Ásia. Por conta desta concentração de empresas do ramo alimentício, a cidade ostenta e o título de "Capital Nacional do Alimento", sendo que muitas empresas utilizam um selo com este slogan em suas embalagens.

De acordo com dados fornecidos pela Adima (2003), estima-se que esta indústria gere no município uma receita bruta direta mensal de $\mathrm{R} \$ 50.000 .000$, sendo responsável por $12 \%$ da produção industrial nacional de alimentos.

Com relação ao setor primário, o município de Marília destaca-se pela produção de café, que é um produto histórico no município uma vez que a cidade foi fundada no caminho da expansão cafeeira do início do século. Além do café, a pecuária de corte e de leite também merece destaque, sendo que o município se constitui em uma das principais bacias leiteiras do tipo B do Estado. Segundo levantamento realizado pelo Sebrae (2001), o setor primário do município se mostra pouco concentrado, já que na região também são produzidos feijão, arroz, amendoim, cana-de-açúcar, milho e frutas.

Marília também possui uma peculiaridade com relação a outros municípios de seu porte (197.153 habitantes). A cidade apresenta um considerável número de instituições de ensino superior como UNESP, Universidade de Marília - UNIMAR, a Fundação de Ensino Eurípides Soares da Rocha e a Faculdade de Medicina de Marília - FAMEMA. 
O município de Marília está localizado na região Centro-Oeste do Estado, a 448 Km da cidade de São Paulo.

\subsubsection{Caracterização do cluster alimentício de Marília/SP}

\section{* Porte das empresas}

Dentre os aspectos gerais analisados por esta pesquisa estão os dados pertinentes ao porte das empresas. Conforme pode ser visualizado pela Tabela 6.1, a maioria das empresas da cidade são de micro e pequeno porte, sendo que as de grande porte correspondem a apenas $10 \%$ do total.

Este dado apresenta-se relevante para a definição da natureza de possíveis propostas de auxílio e oferta de serviços a serem realizados com o intuito de alavancar as empresas do setor alimentício da cidade, uma vez que no Brasil são justamente as MPE's que carecem de incentivos de toda ordem.

TABELA 6.1: Porte das empresas processadoras de alimentos do cluster alimentício de Marília/SP

\begin{tabular}{|l|c|c|}
\hline \multicolumn{1}{|c|}{ Porte } & $\begin{array}{c}\text { Critério Faturamento Anual } \\
(\%)\end{array}$ & $\begin{array}{c}\text { Critério número de funcionários } \\
(\%)\end{array}$ \\
\hline Micro & 45.28 & 57.41 \\
\hline Pequena & 28.30 & 18.52 \\
\hline Média & 15.09 & 11.11 \\
\hline Grande & 9.43 & 9.26 \\
\hline Não Informado & 1.89 & 3.70 \\
\hline TOTAL DE MPE's & $74 \%$ & $76 \%$ \\
\hline
\end{tabular}

\section{* Empregos gerados}

Dado o porte do município, é bastante representativa a quantidade de empregos gerada pela indústria alimentícia local. No entanto, os dados apresentados revelam uma discrepância com relação à quantidade relativa às MPE's do município, que são responsáveis por apenas $9 \%$ dos empregos diretos. Uma possibilidade para esta 
ocorrência pode estar relacionada a baixos investimentos em inovação e pesquisa e desenvolvimento. Estes fatores acarretariam uma baixa perspectivas na busca de outros mercados, inibindo o crescimento destas empresas e a necessidade de contratação de mão-de-obra especializada. Além disto, uma outra possibilidade para este fato se associaria às características desta indústria com relação à sua formação e gestão, uma vez que a maioria destas empresas possui seu gerenciamento e a execução de atividades realizadas pelo próprio proprietário e sua família.

Desta maneira, o potencial destas MPE's na geração de empregos é muito grande, uma vez que isto seria reflexo direto da inserção destas empresas em outros mercados, bem como através de processos de inovação de produtos, processos e gestão.

TABELA 6.2: Total de empregos gerados

\begin{tabular}{|l|c|}
\hline \multicolumn{1}{|c|}{ Porte da empresa } & Número de empregos gerados \\
\hline Total & 6015 empregos diretos \\
\hline Micro & $3.37 \%$ \\
\hline Pequena & $5.80 \%$ \\
\hline Média & $24.59 \%$ \\
\hline Grande & $66.24 \%$ \\
\hline REPRESENTATIVIDADE MPE's & $75 \%$ das empresas \\
& $9 \%$ dos empregos diretos \\
\hline
\end{tabular}

Apesar deste estudo contemplar apenas os números relativos aos empregos diretos gerados pelas empresas do conjunto, estima-se que o setor alimentício gere para a cidade cerca de 12.000 empregos indiretos (Adima, 2003).

\section{* Tempo de existência das empresas pesquisadas}

Esta informação é muito importante para representar a maturidade da indústria alimentícia da cidade. De acordo com os dados da pesquisa de campo realizada pela parceria SEBRAE-SP / FIPE no ano de 2000, o período crítico de mortalidade das empresas é de 5 anos (Figura 6.1). 


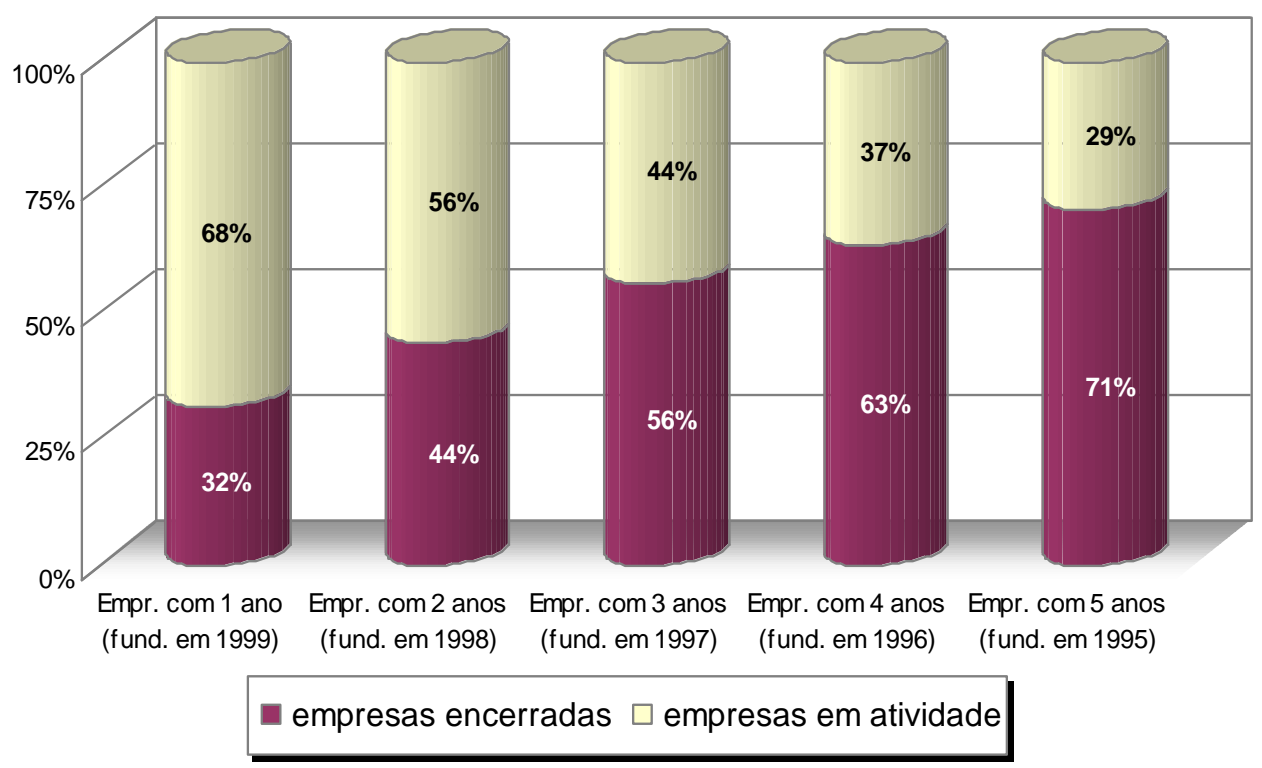

Figura 6.1: Sobrevivência e mortalidade acumulada das empresas do Estado de São Paulo (Fonte: SEBRAESP/FIPE, 2000).

Assim, conforme os dados apresentados pela Figura 6.2, 62\% das empresas do cluster de Marília estão acima do período crítico de mortalidade identificado pela pesquisa SEBRAESP/FIPE, representando, assim, a maturidade da atividade econômica no município.

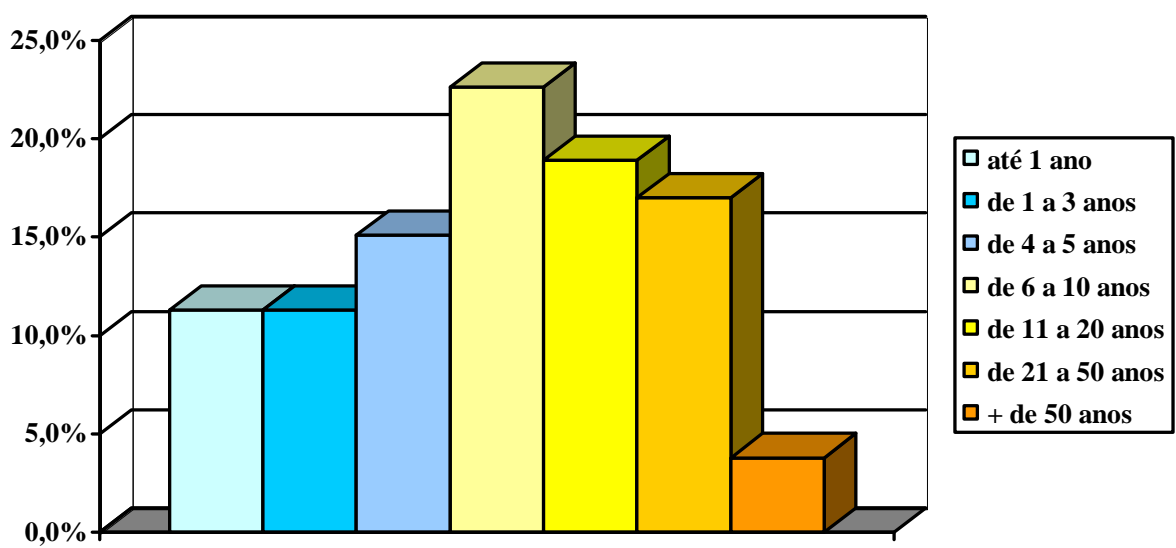

Figura 6.2: Tempo de existência das empresas do cluster de Marília. 


\section{* Linhas de produtos}

Outra característica interessante com relação a este cluster diz respeito à diversidade das linhas de produtos fabricados pelas empresas locais. Foram identificadas 41 diferentes linhas de produtos (Tabela 6.3), demonstrando que existem poucas empresas produzindo o mesmo tipo de produto. Isto representa um fator positivo para este cluster, uma vez que, não sendo a concorrência entre estas empresas direta, fica muito mais fácil a articulação da cooperação e da colaboração entre as mesmas.

Dentre estas diferentes linhas de produto, destaca-se a produção de confeitos, salgadinhos de trigo, biscoitos e balas/gomas, representando aproximadamente $70 \%$ deste total.

Ressalta-se que a maioria destas MPME's trabalha focada nos chamados "produtos de nicho", ou seja, com alimentos pouco diferenciados e, portanto, de valor bem mais baixo que os similares "vedetes" do mercado. Estas empresas atuam no espaço deixado pelas grandes empresas produtoras, visando atingir a população de baixa renda, com produtos de valores bastante baixos para o consumidor.

Exemplos disto são os salgadinhos de trigo e os biscoitos de polvilho que atendem à parcela da população que possui dificuldades financeiras para adquirir produtos líderes de mercado, como os salgadinhos produzidos pela multinacional Elma Chips. 
TABELA 6.3: Linhas de produtos fabricados

\begin{tabular}{|l|c|}
\hline \multicolumn{1}{|c|}{ Produto } & Número de empresas \\
\hline Amendoim / confeitos & 8 \\
\hline Salgadinho de trigo & 6 \\
\hline Confeitos em geral & 4 \\
\hline Biscoitos doces / salgados / recheados & 4 \\
\hline Biscoitos de polvilho & 3 \\
\hline Doces / compotas & 4 \\
\hline Pirulitos & 3 \\
\hline Balas & 3 \\
\hline Goma & 3 \\
\hline Molhos / temperos & 3 \\
\hline Leite / derivados /queijos & 3 \\
\hline Salgados & 8 \\
\hline Bombons / bolos / tortas & 4 \\
\hline Massas & 2 \\
\hline Massas de pizza / pastéis & 2 \\
\hline Mel / derivados & PRODTOS / INHAS \\
\hline TOTAL & \\
\hline
\end{tabular}

\section{* Destino das vendas}

A maior parte das empresas de alimentos da cidade, principalmente as MPE's, possui suas vendas focadas no próprio município e sua região. Por trabalharem com ênfase em custo, seus produtos são pouco diferenciados, dificultando sua inserção em mercados maiores.

Destacam-se, ainda, como possíveis causas para este foco regional, a falta de acesso a canais de distribuição, as dificuldades em arcar com os custos relativos ao transporte dos produtos para regiões mais distantes e a baixa escala de produção.

Quando perguntadas sobre seus principais concorrentes locais, nacionais e internacionais, a maioria destas empresas citou apenas concorrentes locais, fator que reforça sua atuação regional. 
TABELA 6.4: Destino das vendas* das empresas do cluster

\begin{tabular}{|l|c|}
\hline \multicolumn{1}{|c|}{ Destino } & Porcentagem (\%) \\
\hline Exportação & 17 \\
\hline Brasil & 23 \\
\hline Estado de SP & 28 \\
\hline Marília e região & 51 \\
\hline MPE's & FOCO REGIONAL \\
\hline
\end{tabular}

(*) Respostas múltiplas.

\section{* Principais matérias-primas consumidas}

Dentre as principais matérias-primas consumidas por este grupo de empresas, destaca-se o açúcar, utilizado por $25 \%$ das empresas pesquisadas, a farinha de trigo $(17 \%)$, gordura vegetal (11\%), glucose (9\%), sal (9\%), amendoim (9\%) e polvilho $(6 \%)$. O restante $(14 \%)$ corresponde a matérias-primas utilizadas especificamente por algumas empresas, não merecendo destaque neste estudo.

Esta concentração de tipos de matérias-primas utilizadas se constitui em um dado importante, uma vez que poderia justificar estímulos para a instalação de empresas produtoras destes ingredientes na cidade. Isto acarretaria a diminuição nos custos relativos à matéria-prima devido, principalmente, à redução dos custos de transporte.

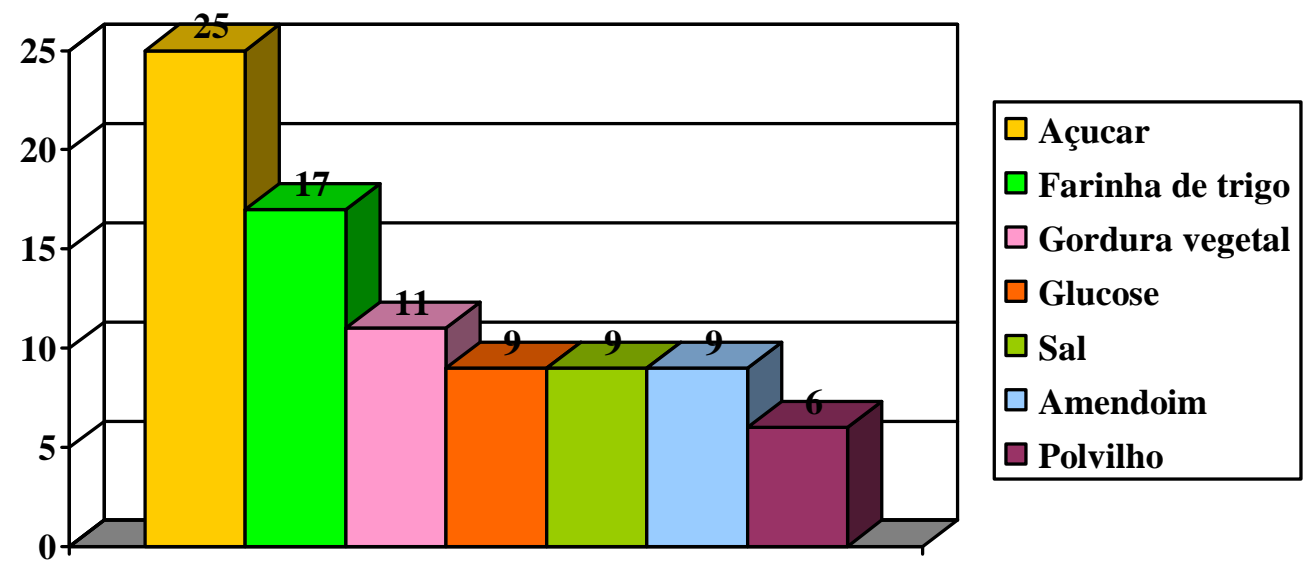

Figura 6.3: Principais matérias-primas utilizadas. 
A Tabela 6.5 mostra o volume mensal de matérias-primas consumido pelas empresas do cluster.

TABELA 6.5: Volume de matérias-primas consumidas.

\begin{tabular}{|c|c|}
\hline Produto & Consumo mensal (toneladas/mês) \\
\hline Farinha de trigo & 5200 \\
\hline Açúcar & 4000 \\
\hline Amendoim & 1200 \\
\hline Gordura vegetal & 1200 \\
\hline Glucose de milho & 535 \\
\hline Polvilho & 124 \\
\hline Amido de milho & 200 \\
\hline Fécula de mandioca & 82 \\
\hline Cacau & 55 \\
\hline Aromas & 5 \\
\hline Leite em pó & 60 \\
\hline Leite in natura & 200.000 litros/mês \\
\hline
\end{tabular}

\section{* Localização dos fornecedores}

Conforme mostrado pela Figura 6.4, 38\% dos fornecedores de matérias-primas para o cluster localiza-se na região de Marília. Isto se deve, em primeiro lugar, à comodidade encontrada nas negociações com fornecedores locais, já que os mesmos visitam as empresas, fazendo vendas com pronta-entrega. Além disto, destaca-se a já discutida redução nos custos de transporte ocasionada por compras de fornecedores regionais.

Apenas 2\% dos fornecedores encontram-se no exterior e correspondem a matérias-primas específicas, cujo conteúdo tecnológico as diferencia das similares nacionais.

Perguntadas sobre as principais razões para a escolha dos fornecedores (razões de compra), $46 \%$ das empresas responderam que a escolha é realizada com base no preço e nas condições de pagamento, enquanto que $30 \%$ delas associam esta escolha à qualidade dos produtos. As demais respostas foram: atendimento (7\%), 
parceria/contrato (4\%), único fornecedor conhecido (4\%), prazo de entrega (2\%), localização do fornecedor $(2 \%)$ e outras $(5 \%)$.

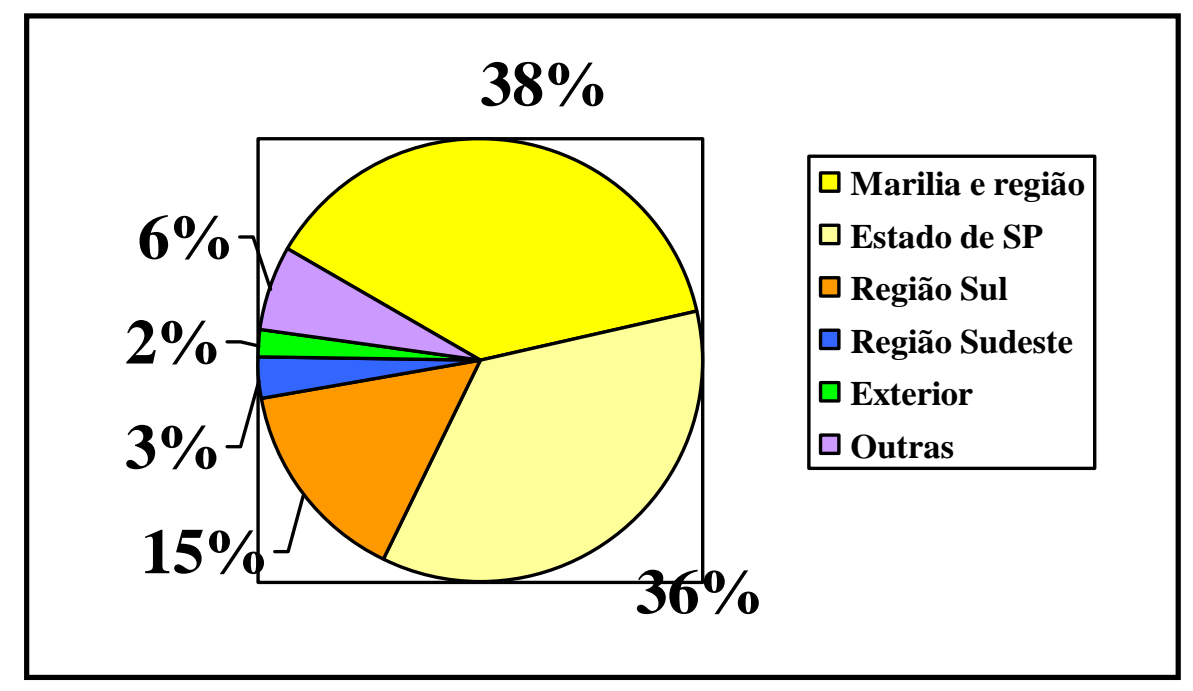

Figura 6.4: Localização dos fornecedores.

\section{* Empresas identificadas e pesquisadas}

Estão listadas no Anexo IV as empresas processadoras de alimentos identificadas (58 empresas) e as empresas efetivamente pesquisadas (55). Apenas três empresas não tiveram interesse em contribuir com esta pesquisa.

Destaca-se que 2 empresas deste conjunto são informais e foram identificadas durante as entrevistas realizadas junto às empresas. Acredita-se, porém, que o número de empresas informais seja bem maior, compondo-se por micro empresas que produzem produtos caseiros (artesanais) para festas e eventos.

Ressalta-se, assim, a importância de ações para o incentivo à formalização das MPE's desta indústria, para que estas empresas, através de sua regulamentação, possam ser conhecidas e apoiadas no seu desenvolvimento técnico e gerencial.

\section{* Principais dificuldades operacionais}

Com relação às principais dificuldades operacionais enfrentadas por estas empresas, apenas $21 \%$ das mesmas alegam não enfrentar nenhum tipo de dificuldade. 
As demais (79\%) apresentam dificuldades operacionais variadas, sendo que a falta de mão-de-obra qualificada e de fornecedores de matérias-primas, custos gerais e acesso a novos clientes constituem-se na principal parcela das reclamações apresentadas. Estes dados estão detalhadamente expressos na Tabela 6.6.

TABELA 6.6: Principais dificuldades operacionais enfrentadas pelas empresas.

\begin{tabular}{|c|c|}
\hline Dificuldade operacional & Porcentagem $^{*}{ }^{*}$ ) \\
\hline Falta de mão-de-obra qualificada & $24 \%$ \\
\hline Falta de fornecedores locais & $21 \%$ \\
\hline Custos gerais & $15 \%$ \\
\hline Vendas: acesso a novos clientes & $10 \%$ \\
\hline Acesso a financiamento/capital de giro & $10 \%$ \\
\hline Compra e assistência técnica de equipamentos & $8 \%$ \\
\hline Racionamento de energia & $6 \%$ \\
\hline Não tem & $21 \%$ \\
\hline
\end{tabular}

(*) Respostas múltiplas

Em um nível maior de detalhamento, foram questionadas quais as principais dificuldades enfrentadas especificamente com relação ao aporte de matérias-primas. O resultado desta questão está exposto na Tabela 6.7.

Ainda com relação às dificuldades operacionais, as empresas foram também questionadas sobre o que tange à compra e à manutenção de equipamentos e às análises laboratorais que devem ser efetuadas nos produtos. Com relação ao primeiro item, 32\% das empresas afirmaram possuir problemas com a aquisição de equipamentos, relacionados, sobretudo, à falta de empresas locais de projeto e venda dos mesmos. Além disso, $43 \%$ alegaram possuir problemas relacionados, principalmente, à falta de empresas prestadoras de manutenção locais, afirmando que muitas vezes há a parada do setor produtivo, justamente pela ausência de empresas especializadas em manutenção de equipamentos no município.

Já com relação aos laboratórios de análises em produtos, $42 \%$ das empresas entrevistadas reclamaram a ausência de laboratórios especializados tanto em análises microbiológicas quanto físico-químicas. 
Destaca-se, ainda, que $43 \%$ das empresas alegaram possuir dificuldades específicas na compra de embalagens (plásticas, de papel e de papelão), vinculadas, principalmente, à falta de fornecedores locais destes produtos. Este dado é especialmente relevante, dado o volume de embalagens consumidas pelas empresas alimentícias do município: 70.000 embalagens/mês (Adima, 2003).

TABELA 6.7: Principais dificuldades enfrentadas no aporte de matérias-primas.

\begin{tabular}{|c|c|}
\hline Dificuldade enfrentada & Porcentagem \\
\hline Oferta irregular/sazonalidade & $26 \%$ \\
\hline Faltam fornecedores locais & $19 \%$ \\
\hline Preço/prazo de pagamento & $11 \%$ \\
\hline Baixa qualidade & $11 \%$ \\
\hline Custo do frete & $4 \%$ \\
\hline Linhas de crédito & $4 \%$ \\
\hline Importação & $4 \%$ \\
\hline Outras respostas & $21 \%$ \\
\hline
\end{tabular}

\section{* Caracterização do ambiente institucional}

A caracterização do ambiente externo às empresas se faz muito importante uma vez que a evolução e direcionamento das organizações dependem não apenas das ações tomadas em seu ambiente interno, mas das ocorrências e incentivos ocorridos (ou não) em seu ambiente institucional, conforme visto no capítulo 2 deste trabalho.

Desta maneira, a Tabela 6.8 sintetiza alguns dos atores presentes neste município, cujas ações, direta ou indiretamente, afetam, em algum grau, o andamento das empresas estudadas. 
TABELA 6.8: Instituições localizadas na cidade de Marília/SP, divididas de acordo com o nível administrativo a que pertencem (municipal, estadual e federal).

\begin{tabular}{|c|c|}
\hline Municipal & Papel \\
\hline $\begin{array}{l}\text { Secretaria da Indústria e } \\
\text { Comércio (órgão municipal) }\end{array}$ & Fomentar desenvolvimento local. \\
\hline $\begin{array}{l}\text { ADIMA - Associação da } \\
\text { Indústria de Alimentos de } \\
\text { Marília }\end{array}$ & $\begin{array}{l}\text { Associação de classe operante pela contribuição } \\
\text { financeira de sócios-voluntários. }\end{array}$ \\
\hline $\begin{array}{l}\text { GEAD - Grupo de Entidades } \\
\text { de apoio ao desenvolvimento }\end{array}$ & $\begin{array}{l}\text { Articula lideranças dos organismos voltados ao fomento } \\
\text { da indústria alimentícia local. Objetiva evitar } \\
\text { pulverização de esforços, através da concentração de } \\
\text { lideranças em reuniões quinzenais. }\end{array}$ \\
\hline $\begin{array}{l}\text { Sindicato dos trabalhadores } \\
\text { da indústria da alimentação. }\end{array}$ & $\begin{array}{l}\text { Representação dos empregados da indústria alimentícia } \\
\text { local. }\end{array}$ \\
\hline $\begin{array}{l}\text { Universidades e centros de } \\
\text { pesquisa: Fundação de } \\
\text { Ensino e Unimar. }\end{array}$ & $\begin{array}{l}\text { Além de formação de pessoal qualificado, incentivo e } \\
\text { investimentos em pesquisas ligadas ao produto, ao } \\
\text { processo e gestão. }\end{array}$ \\
\hline Federal & Papel \\
\hline $\begin{array}{l}\text { SESI } \\
\text { SENAI } \\
\text { SEBRAESP }\end{array}$ & $\begin{array}{l}\text { Entidades do grupo S, montado no tempo de Getúlio } \\
\text { Vargas e presidido pela Fiesp. Opera através de } \\
\text { contribuições patronais. }\end{array}$ \\
\hline Estadual & Papel \\
\hline $\begin{array}{l}\text { ERPLAN - Secretaria de } \\
\text { desenvolvimento econômico }\end{array}$ & $\begin{array}{l}\text { Reunião de dados, políticas para o desenvolvimento } \\
\text { econômico regional. Mantido pelo orçamento público } \\
\text { estadual. }\end{array}$ \\
\hline CIESP & $\begin{array}{l}\text { Representa os sindicatos patronais. Mantido por verbas } \\
\text { do sistema S. }\end{array}$ \\
\hline
\end{tabular}

\subsubsection{Considerações sobre a Etapa 1 da pesquisa}

Dentre os principais pontos que caracterizam estas empresas, destaca-se a grande quantidade de MPE's deste conjunto. Isto se constitui em um fator de bastante relevância para a definição das ações a serem tomadas em benefício do setor.

Destacam-se também a maturidade do setor no município, com $62 \%$ das empresas contando com mais de 5 anos de operação e a diversidade de linhas de produtos produzida.

Além disso, salientam-se as principais dificuldades encontradas por estas empresas, como a falta de fornecedores locais para grande parte das matérias-primas e embalagens necessárias para as suas operações. Dentre as principais reclamações 
apresentadas por estas empresas está a sua carência por empresas que produzem e prestam manutenção em equipamentos utilizados no setor produtivo. Acrescenta-se, ainda, a ausência de empresas locais especializadas na realização análises laboratoriais, tanto nas matérias-primas quanto nos produtos acabados das empresas, já que a maioria delas não possui este tipo de serviço internamente em suas estruturas.

No entanto, apenas esta etapa de caracterização não se mostra suficiente para a realização da análise competitiva deste aglomerado. Além disso, a afirmação de que a solução das dificuldades operacionais apresentadas trará reais benefícios para estas empresas é aqui prematura.

Neste contexto, fica evidente a necessidade de um estudo mais aprofundado, com o objetivo de identificar e avaliar aspectos relevantes relacionados tanto à estrutura interna destas empresas quanto às condições encontradas em seu ambiente institucional. Além destes, destaca-se, ainda, a necessidade da avaliar se as condições apresentadas por este grupo de empresas são propícias para o aproveitamento de todas as vantagens que podem ser auferidas pelos clusters completos, tais como o número de empresas interessadas em colaborar entre si, o grau de confiança presente entre elas, entre outros.

Com o objetivo de aprofundar nestas questões, a seguir são apresentados e discutidos os dados da Etapa 2 da pesquisa de campo deste trabalho. Observa-se que, pelo fato de a maior parte destas empresas serem de micro e pequeno porte, esta próxima etapa da pesquisa enfoca especificamente neste conjunto de empresas (MPE's).

\subsection{Etapa 2: a competitividade do cluster de Marília/SP}

Conforme já discutido na metodologia deste trabalho, esta etapa da pesquisa visa a análise de fatores pertinentes à competitividade das empresas do cluster em questão. Os dados coletados estão discutidos de acordo com a disposição proposta na metodologia desta tese (capítulo 5). Assim, inicialmente é realizada a análise do ambiente interno às empresas. Depois disso, então, estão analisados os aspectos 
relativos à cooperação entre as mesmas. E, por fim, é realizada a análise dos fatores competitivos relacionados ao ambiente institucional do referido cluster.

\subsubsection{Análise da estrutura interna das empresas}

De acordo com a metodologia que norteia este trabalho, das cinco linhas de produtos classificadas, foram entrevistadas duas empresas: uma de micro e outra de pequeno porte, perfazendo um total de dez empresas pesquisadas.

A Tabela 6.9 traça uma tipificação de cada uma destas empresas. Ressalta-se que os nomes das empresas foram omitidos a pedido dos representantes das mesmas.

TABELA 6.9: Empresas do cluster pesquisadas

\begin{tabular}{|c|c|c|c|}
\hline $\begin{array}{c}\text { Denominação da } \\
\text { Empresa }\end{array}$ & Produtos produzidos & $\begin{array}{c}\text { Número de } \\
\text { funcionários }\end{array}$ & Porte \\
\hline Empresa 1 & Pirulitos & 19 & Micro-empresa \\
\hline Empresa 2 & Pirulitos & 26 & Pequena-empresa \\
\hline Empresa 3 & Salgadinhos de trigo & 19 & Micro-empresa \\
\hline Empresa 4 & Salgadinhos de trigo & 46 & Pequena-empresa \\
\hline Empresa 5 & Biscoito de polvilho & 6 & Micro-empresa \\
\hline Empresa 6 & Biscoitos de polvilho & 32 & Pequena-empresa \\
\hline Empresa 7 & Confeitos de amendoim & 10 & Micro-empresa \\
\hline Empresa 8 & Confeitos de amendoim & 29 & Pequena-empresa \\
\hline Empresa 9 & Pipoca & 3 & Micro-empresa \\
\hline Empresa 10 & Achocolatados & 25 & Pequena-empresa \\
& $\begin{array}{c}\text { Farináceos } \\
\text { Especiarias }\end{array}$ & & \\
\hline
\end{tabular}

\section{* Empresa 1:}

Principal produto: pirulitos

Idade da empresa: 6 anos

Número de funcionários: 19 
Sistema de produção: semi-artesanal

Segundo o proprietário da empresa, ela surgiu através da ampliação de um negócio familiar já existente. O proprietário inventou a massa que compõem a base dos pirulitos e os produzia inicialmente em escala modesta. Com a rápida aceitação do produto no mercado, principalmente devido a seu baixo preço, o mesmo passou a ser produzido em maior escala, mas ainda prevalecendo o modo simples e artesanal de produção. A empresa vende exclusivamente no atacado para o mercado interno através de atacadistas e vendedores autônomos, sobretudo para o Paraná, Santa Catarina, Mato Grosso e São Paulo e, no momento da entrevista, estavam sendo desenvolvidos os mercados dos estados do Rio Grande do Sul e Roraima. Cerca de $80 \%$ da distribuição dos produtos é feita pela própria empresa, que possui 2 caminhões para esta finalidade.

A empresa possui como principal critério de desempenho o custo de seu produto e, de acordo com o proprietário, este critério tem sido assegurado a duras penas devido ao aumento constante no preço das principais matérias-primas utilizadas (açúcar e corantes).

Nos últimos anos foi observado um aumento velado na concorrência nacional. Porém, a empresa freqüentemente recebe propostas para a exportação, sobretudo para a América Latina, mas o atendimento a esses pedidos reflete na ampliação da empresa, fator este descartado pela falta de capital para tal.

Com relação à infra-estrutura da empresa, a idade do principal produto e dos equipamentos da empresa acompanha seu tempo de fundação: 6 anos. Desde lá, nenhum tipo de alteração foi realizado nos produtos ou processos, que operam apenas com pequenos ajustes que possibilitaram o aumento progressivo da produção ao longo do tempo de existência da mesma. Não há, portanto, uso de dispositivos de microeletrônica e o prédio onde a empresa está instalada é alugado.

A gestão da empresa é feita pelo próprio proprietário e outros membros da família cooperam na administração da empresa. Quanto à gestão dos recursos humanos, não é oferecido qualquer tipo de benefício aos funcionários e o treinamento é realizado apenas quando o funcionário ingressa na empresa. 
Há total desconhecimento de técnicas de gestão por parte da direção da empresa, que também desconhece a norma ISO 9000.

O controle de qualidade da produção é apenas visual e sem sistematização ou existência de pessoas especializadas em controle. Não há pessoal especializado em tecnologia de alimentos na empresa e sua autorização de funcionamento se dá através da assinatura de um químico que realiza uma visita mensal à empresa.

Desta forma, o empresário opera de maneira bastante intuitiva, não havendo qualquer formalidade na formulação de estratégias, que são definidas de acordo com o "feeling" do proprietário.

Com relação à captação de recursos financeiros, a empresa apela para a utilização de recursos do crédito privado, queixando-se das altas taxas de juros praticadas e da falta de linha especial de crédito para as MPE's, uma vez que as garantias materiais exigidas para fazer um empréstimo muitas vezes faltam às empresas de pequeno porte. Não se realiza pesquisa ou desenvolvimento de novos produtos, e, segundo o proprietário, a maior competitividade da empresa é assegurada pelo baixo custo do produto.

Quanto às aquisições de matérias-primas, a empresa alega possuir dificuldades em comprar diretamente dos produtores devido ao baixo volume negociado. Desta maneira, o caminho é comprar através de intermediários que, além de encarecer o produto, não apresentam a pontualidade necessária na entrega. A estratégia de compras se volta para menores preços e prazos de entrega.

A maior parte dos fornecedores da empresa está na cidade de São Paulo, não havendo nenhum tipo de parceria com os mesmos e a confiança se dá em apenas $50 \%$ deles.

Como já citado, o sistema de produção da empresa é semi-artesanal e não há definição dos postos de trabalho, sendo que os funcionários da empresa estão aptos para operar em praticamente todos os postos existentes. Quanto à estrutura e maquinário, notou-se uma falta de preocupação com os quesitos específicos e fundamentais para a produção de alimentos, como bancadas e equipamentos em aço inoxidável.

Com relação ao marketing do produto, a propaganda é feita "boca-a-boca", e a empresa utiliza o selo "Marília Capital do Alimento" em suas embalagens. 
O empresário alega já ter ouvido falar que Marília se constitui em um cluster alimentício, mas não tem idéia do que se trata. A empresa realiza cooperação com algumas empresas específicas (concorrentes indiretos) através de troca de matériasprimas e do rateio fretes para regiões distantes.

A empresa não descarta a possibilidade de realizar parcerias com seus concorrentes, apesar de achar a prática muito arriscada.

Sobre o tecido institucional, o empresário alega haver uma assimetria de poder, principalmente entre as grandes e as pequenas empresas, uma vez que estas últimas carecem de incentivos e de benefícios de toda ordem. A principal queixa do empresário se dá com relação à falta de linhas de crédito para empresas de pequeno porte, que se obrigam a recorrer aos bancos privados, cujo processo é muito burocrático. A empresa realiza a troca de cheques pré-datados para aumento de seu capital de giro. Outras reclamações foram sobre os altos impostos e pedágios muito caros, além da distância dos principais fornecedores de matérias-primas.

Com relação à opinião da empresa sobre a atuação entidades presentes na cidade, a Tabela 6.10 resume as impressões do empresário sobre cada uma delas. Percebe-se que, neste caso, a integração da empresa com as entidades do tecido institucional é bastante fraca.

TABELA 6.10: Impressões da Empresa 1 sobre entidades do tecido institucional.

\begin{tabular}{|c|c|}
\hline Entidade & Impressão \\
\hline $\begin{array}{l}\text { Secretaria da Indústria e } \\
\text { Comércio (órgão municipal) }\end{array}$ & $\begin{array}{l}\text { Há } 2 \text { anos houve a promessa de doação de um terreno de } \\
2500 \text { m2 que até hoje não ocorreu. }\end{array}$ \\
\hline ADIMA & $\begin{array}{l}\text { Percebe iniciativas para a promoção da cidade como } \\
\text { capital do alimento, como feiras, por exemplo. }\end{array}$ \\
\hline GEAD & Desconhece a entidade. \\
\hline $\begin{array}{l}\text { Sindicato dos trabalhadores } \\
\text { da indústria da alimentação. }\end{array}$ & $\begin{array}{l}\text { A empresa alega já ter tido alguns problemas com } 0 \\
\text { órgão, sem esclarecer quais. }\end{array}$ \\
\hline $\begin{array}{l}\text { Universidades e centros de } \\
\text { pesquisa }\end{array}$ & Não possui contato. \\
\hline $\begin{array}{l}\text { SESI } \\
\text { SENAI } \\
\text { SEBRAESP }\end{array}$ & $\begin{array}{l}\text { O Senai já promoveu visitas na empresa visando o auxílio } \\
\text { na construção de novos equipamentos, mas nada vingou. } \\
\text { O Sebrae é visto apenas como promotor de palestras. }\end{array}$ \\
\hline ERPLAN & Desconhece a entidade. \\
\hline CIESP & Não possui contato com a entidade. \\
\hline
\end{tabular}


* Empresa 2:

Principal produto: pirulitos tipo chupeta

Idade da empresa: 5 anos

Número de funcionários: 26

Sistema de produção: semi-artesanal

O negócio surgiu por iniciativa familiar. O pai do proprietário já possui uma empresa local que produz confeitos de amendoim e esta empresa foi inaugurada fabricando inicialmente pipocas doces. Porém, há 5 anos a empresa passou a produzir os atuais pirulitos, que se constituem em seu principal produto. A empresa também realiza a embalagem de produtos provenientes da empresa do pai, aos quais é colocada a marca própria da empresa em questão. Porém este negócio representa apenas $20 \%$ do montante negociado.

O custo é o critério de desempenho adotado pela empresa, e quanto à concorrência, ela alega não possuir, pois apenas mais uma única empresa no Brasil fabrica este tipo de pirulito. Quanto ao aumento das exigências dos clientes, esta se dá apenas por um maior volume de produção, uma vez que a empresa não possui condições de atender a todos os pedidos que recebe e a ampliação da empresa está limitada pela falta de capital de giro. Além disso, os clientes reclamam do grande prazo que a empresa exige para a entrega de seus produtos, que gira em torno de 15 dias.

A idade do seu principal produto é de 5 anos, assim como a idade dos principais equipamentos. A produção é artesanal e o prédio em que está alocada a empresa é alugado.

Quanto à tecnologia de gestão, os dirigentes desta empresa também apresentam um total desconhecimento de técnicas gerenciais, incluindo o Sistema de Qualidade ISO 9000. Não há inspeção de qualidade no produto fabricado

Não há estratégia formal e os investimentos da empresa são feitos de maneira não programada. A definição dos "rumos" da empresa se dá pelas sugestões feitas pelos principais clientes. A empresa vende apenas no atacado e para o mercado interno, especificamente para os estados de São Paulo e Paraná e regiões Norte e 
Nordeste do país. A empresa já foi consultada para a possibilidade de exportar seus produtos para os países Chile e Argentina, mas a falta de capital impede que a empresa trace metas mais ambiciosas com relação à ampliação de seu mercado consumidor. A distribuição dos produtos vendidos é feita por empresas terceirizadas.

Para a captação de recursos financeiros, a empresa utiliza a prática de troca de cheques pré-datados, a juros mensais de aproximadamente $6 \%$. Os representantes da empresa reclamam da falta de linhas especiais de crédito para as empresa de pequeno porte.

A empresa opera com o mesmo produto desde a sua inauguração, não havendo investimentos em P\&D.

As compras da empresa são baseadas no menor preço das matérias-primas. Não são realizados testes no recebimento de matérias-primas e a empresa confia nos laudos enviados pelas empresas fornecedoras.

A definição dos postos de trabalho é estreita, com cada funcionário executando apenas uma função específica.

Os empresários acreditam que seus clientes consomem seu produto basicamente pelo baixo custo dos mesmos, uma vez que a empresa não realiza qualquer tipo de propaganda. Nem mesmo o selo "Marília Capital do Alimento" é utilizado, já que a embalagem do pirulito é muito pequena para abrigá-lo.

Os representantes da empresa não têm idéia do que significa um cluster e a única parceria adotada é com a empresa do pai do proprietário, rateio de fretes e trocas de matérias-primas.

A empresa não participaria de nenhuma forma de cooperação com seus concorrentes diretos ou indiretos, uma vez que não possui confiança em outras empresas quando se trata de negócios.

Os empresários configuram a rede de poder local como assimétrica, vendo a atitude das entidades de classe locais voltadas exclusivamente para as empresa de grande porte. As impressões desta empresa sobre as entidades que compõem o tecido institucional estão resumidas na Tabela 6.11. 
TABELA 6.11: Impressões da Empresa 2 sobre entidades do tecido institucional

\begin{tabular}{|c|c|}
\hline Entidade & Impressão \\
\hline $\begin{array}{l}\text { Secretaria da Indústria e } \\
\text { Comércio (órgão municipal) }\end{array}$ & Atuação não atinge a empresa. \\
\hline ADIMA & $\begin{array}{l}\text { Não enxerga nenhuma utilidade nas ações proposta pela } \\
\text { entidade. }\end{array}$ \\
\hline GEAD & Desconhece a entidade. \\
\hline $\begin{array}{l}\text { Sindicato dos trabalhadores } \\
\text { da indústria da alimentação. }\end{array}$ & A entidade é vista somente como fonte de exigências. \\
\hline $\begin{array}{l}\text { Universidades e centros de } \\
\text { pesquisa }\end{array}$ & Não há contato. \\
\hline $\begin{array}{l}\text { SESI } \\
\text { SENAI } \\
\text { SEBRAESP }\end{array}$ & $\begin{array}{l}\text { A empresa possui conhecimento de que o Sesi promove } \\
\text { curso sobre o processamento de alimentos, mas nunca } \\
\text { participou. } \\
\text { O Sebrae é visto apenas como promotor de palestras, que } \\
\text { do ponto de vista do empresário não possui serventia para } \\
\text { as empresas. }\end{array}$ \\
\hline ERPLAN & Desconhece a entidade. \\
\hline CIESP & Não possui contato com a entidade. \\
\hline
\end{tabular}

* Empresa 3:

Principal produto: salgadinhos de trigo (5 sabores)

Idade da empresa: 2 anos

Número de funcionários: 21

Sistema de Produção: semi-artesanal

O surgimento da empresa se deu por ampliação de um negócio familiar já existente. A empresa fabricava pipocas e passou a fabricar pirulitos do tipo "chupeta" há 5 anos, e há 2 anos montou esta empresa de salgadinhos de trigo. O processo produtivo desta empresa foi montado com a ajuda de dois ex-funcionários de uma empresa fabricante deste produto.

O critério de desempenho adotado pela empresa é o custo, ou seja, apesar de alegar o primor pela qualidade de seus produtos, a empresa compete no mercado através do baixo preço.

Os empresários afirmam não sofrer concorrência mundial. O que tem havido é um aumento da concorrência nacional. 
Quanto à exigência de mercado atual esta se dá para que haja aumento da oferta dos produtos da empresa. Mas a empresa carece de fontes de recursos financeiros para aumentar os turnos ou investir em matérias-primas em maior quantidade.

Quanto à sua infra-estrutura, a idade do principal produto é de 2 anos (data da fundação da empresa) e desde lá nenhum produto foi lançado ou modificado. A idade dos equipamentos principais também acompanha o surgimento da empresa. Não são utilizados dispositivos de microeletrônica, sendo todo o processo mecânico. O prédio onde se situa a empresa é alugado.

Quanto às estratégias de Recursos Humanos, a empresa não cede nenhum benefício aos seus funcionários, não havendo, assim, uma política de RH. O treinamento de funcionários é feito sem sistematização, sendo realizado apenas quando da contratação de novos membros para o setor produtivo.

Não são conhecidas técnicas gerenciais, havendo total desconhecimento acerca da norma ISO 9000. A inspeção no processo produtivo é feita apenas visualmente durante a pesagem, sendo executada pelo próprio operador no ato da embalagem do produto, não havendo inspetores de qualidade.

A empresa não possui estratégia formal e os investimentos da mesma são feitos de maneira não programada. A estratégia informal adotada baseia-se no custo do produto e a empresa trabalha em um determinado "nicho" de mercado. As informações para a definição dos "rumos" da empresa se dão através dos clientes da mesma. O próprio surgimento da empresa foi através de informações dos clientes da empresa anterior sobre a possibilidade de comercialização de salgadinhos de trigo para os mercados já abrangidos pela empresa (regiões Norte e Nordeste, estados de São Paulo e Paraná).

Com relação ao transporte, este é terceirizado, sendo utilizadas firmas que compõem a carga dos caminhões exclusivamente com produtos da empresa. A empresa opera apenas no atacado.

A empresa trabalha somente com mercado interno, alegando não exportar devido à falta de recursos financeiros para de investir em um maior volume de produção. Ela já foi visitada por empresários da Argentina e do Chile que 
conheceram seus produtos através dos distribuidores, mas declinaram o convite de exportação por falta de capacidade para atendimento a novos pedidos.

De acordo com os empresários, a falta de linhas de crédito para MPE's se constitui no maior problema para alavancar os negócios da mesma. A empresa possui baixo capital de giro, necessitando praticar com frequência a troca de cheques prédatados nos bancos a juros mensais de $5,8 \%$.

Não há investimentos em $P \& D$ e os investimentos para maior competitividade centram-se efetivamente nos baixos custos dos produtos fabricados.

Com relação à aquisição de matérias-primas da empresa, a estratégia de compras está voltada para o menor preço, desde que atenda a padrões mínimos de qualidade. A maior parte dos fornecedores da empresa localiza-se no Estado de São Paulo. Não são realizados testes na recepção das matérias-primas, sendo que a empresa confia nos laudos enviados pelos fornecedores. Não há programas de apoio ou parcerias com os fornecedores.

A definição dos postos de trabalho é rígida, sendo que cada funcionário executa apenas uma tarefa dentro da empresa, não havendo polivalência das funções.

Quanto ao marketing do produto, não são feitas propagandas do mesmo e a empresa acredita que o sucesso de vendas do produto esteja vinculado aos baixos preços e à forte identificação dos consumidores com a marca. A empresa utiliza o selo "Marília Capital do Alimento" em suas embalagens.

Há um completo desconhecimento por parte dos representantes da empresa em relação ao conceito de cluster e a empresa participa de cooperação com outras empresas do setor, através de compra conjunta de matérias-primas e empréstimos em caso de falta. Também são realizadas parcerias no caso de fretes para regiões mais distantes.

A principal queixa dos representantes da empresa se dá pela falta de capital para a ampliação e realização de melhorias na empresa, situação que se agrava pela dificuldade de se conseguir crédito pelos meios convencionais.

A empresa julga que há uma assimetria de poder com relação às grandes empresas, e, segundo a ótica de seus representantes, as iniciativas das entidades locais visam o favorecimento das empresas de maior porte. As impressões da empresa com relação às entidades locais estão resumidas na Tabela 6.12. Destaca-se 
a falta de crédito desta empresa nestas entidades, cujas ações são encaradas com muita desconfiança.

TABELA 6.12: Impressões da Empresa 3 sobre entidades do tecido institucional.

\begin{tabular}{|c|c|}
\hline Entidade & Impressão \\
\hline $\begin{array}{l}\text { Secretaria da Indústria e } \\
\text { Comércio (órgão municipal) }\end{array}$ & Atuação não atinge a empresa \\
\hline ADIMA & $\begin{array}{l}\text { Não vê nenhuma utilidade nas ações proposta pela } \\
\text { entidade. }\end{array}$ \\
\hline GEAD & Desconhece a entidade. \\
\hline $\begin{array}{l}\text { Sindicato dos trabalhadores } \\
\text { da indústria da alimentação. }\end{array}$ & Somente exigências. \\
\hline $\begin{array}{l}\text { Universidades e centros de } \\
\text { pesquisa }\end{array}$ & $\begin{array}{l}\text { A empresa contratou um estagiário de Engenharia de } \\
\text { Alimentos da UNIMAR por apenas } 40 \text { dias, não vendo } \\
\text { benefícios na colaboração. }\end{array}$ \\
\hline $\begin{array}{l}\text { SESI } \\
\text { SENAI } \\
\text { SEBRAESP }\end{array}$ & $\begin{array}{l}\text { A empresa possui conhecimento de que o Sesi promove } \\
\text { curso sobre o processamento de alimentos, mas nunca } \\
\text { participou. } \\
\text { O Sebrae é visto apenas como promotor de palestras, que } \\
\text { do ponto de vista do empresário não possui serventia para } \\
\text { as empresas. }\end{array}$ \\
\hline ERPLAN & Desconhece a entidade. \\
\hline CIESP & Não possui contato com a entidade. \\
\hline
\end{tabular}

\section{* Empresa 4:}

Principal produto: salgadinhos de trigo e de milho (6 sabores)

Idade da empresa: 12 anos

Número de funcionários: 46

Sistema de Produção: semi-artesanal

Esta empresa surgiu através de ampliação de uma tradição familiar na produção de alimentos. Além da produção de salgadinhos de trigo, a empresa empacota confeitos de amendoim e gomas provenientes de outra empresa local.

Seu gerenciamento é feito por dois irmãos que são sócios, sendo que um deles se responsabiliza pela parte comercial e o outro cuida das questões relativas ao setor produtivo. 
O destino das vendas da empresa se concentra na região Nordeste do país, que consome $50 \%$ dos produtos fabricados pela empresa. Os outros $50 \%$ estão destinados às cidades de São Paulo e no Estado do Rio de Janeiro. As vendas são feitas apenas por atacado e os maiores pontos de venda são camelôs e lojas de produtos populares, do tipo que comercializa produtos a $\mathrm{R} \$ 1,99$.

A empresa tem sentido um aumento de concorrência, sobretudo pela expansão de empresas atuando no mesmo setor, competindo com produtos similares a um menor preço.

As exigências dos clientes têm aumentado, principalmente para melhorias na embalagem e na pressão pela diversificação das opções de sabores oferecidos.

O mais recente produto lançado pela empresa é o salgadinho de milho, efetuado a menos de um ano. Na ocasião deste lançamento, foram realizados investimentos na empresa, com a ampliação do volume de produção, investimentos em equipamentos, acompanhados pela mudança de prédio, que é alugado.

$\mathrm{O}$ equipamento mais recente adquirido pela empresa possui 6 meses e se constitui em uma máquina de embalagem a vácuo.

O sistema de produção da empresa é em massa e o uso de dispositivos de microeletrônica é feito apenas no equipamento adquirido mais recentemente. Ainda sobre o setor produtivo, destaca-se a polivalência dos seus funcionários, treinados para operar em todos os postos de trabalho. Porém, os empregados só são treinados no ato da contratação.

Quanto à gestão, há completo desconhecimento sobre as mesmas. Também não há qualquer garantia ou benefício oferecido aos funcionários.

Não são realizados controles de qualidade nem no processo produtivo e tampouco nos produtos acabados. Existe um químico que assina para que a empresa opere e o mesmo visita a empresa apenas uma vez por mês, ou na ocasião da ocorrência de algum problema no produto.

A estratégia da empresa é informal, focando mais especificamente no custo do produto. Os proprietários alegam a constante visita a feiras e congressos, visando a atualização sobre o setor em que atuam. 
Os recursos financeiros da empresa são adquiridos através do crédito privado, mas a empresa alega enfrentar muitas dificuldades para tal, uma vez que as exigências de garantias materiais são bastante grandes.

As pesquisas para o lançamento de novos produtos são realizadas pelos proprietários na própria linha de produção, eventualmente com a ajuda do químico responsável pela empresa.

O menor preço norteia a escolha dos fornecedores e as relações são meramente comerciais, embora não haja reclamações sobre os mesmos. A maioria dos fornecedores localiza-se na cidade de São Paulo e há queixa com relação à falta de fornecedores locais.

Não são realizados testes nas matérias-primas adquiridas, havendo confiança plena nos laudos oferecidos pelos fornecedores.

De acordo com os proprietários, os consumidores apresentam forte identificação com a marca de seus produtos, embora reconheçam que o fator preço tem um peso bastante grande para o cliente na hora de optar pelos mesmos.

A divulgação do produto através de propagandas é inexistente e a empresa utiliza o selo "Marília Capital do Alimento" em suas embalagens.

Os proprietários alegam ignorância a respeito do conceito de cluster e quanto a parcerias, a empresa já realizou e se sentiu lesada com isso, não tendo intenções de voltar a realizá-las.

Nesta empresa, os representantes possuem como maior queixa a assimetria de poder, principalmente nos incentivos e nas linhas de crédito, que acabam por beneficiar as empresas de maior porte. Para efetuar as ampliações citadas no início deste texto, a empresa teve que recorrer à venda de bens para a aquisição do capital necessário.

Quanto às impressões desta empresa a respeito das entidades presentes no tecido institucional do município, elas se encontram na Tabela 6.13. 
TABELA 6.13: Impressões da Empresa 4 sobre entidades do tecido institucional.

\begin{tabular}{|l|l|}
\hline \multicolumn{1}{|c|}{ Entidade } & \multicolumn{1}{|c|}{ Impressão } \\
\hline $\begin{array}{l}\text { Secretaria da Indústria e } \\
\text { Comércio (órgão municipal) }\end{array}$ & Atuação não atinge a empresa. \\
\hline ADIMA & $\begin{array}{l}\text { Não enxerga nenhuma utilidade nas ações proposta pela } \\
\text { entidade. }\end{array}$ \\
\hline GEAD & $\begin{array}{l}\text { Acredita que a entidade só favorece as grandes } \\
\text { empresas. }\end{array}$ \\
\hline $\begin{array}{l}\text { Sindicato dos trabalhadores } \\
\text { da indústria da alimentação. }\end{array}$ & Não possui contato com a entidade. \\
\hline $\begin{array}{l}\text { Universidades e centros de } \\
\text { pesquisa }\end{array}$ & Não possui contato com a entidade \\
\hline $\begin{array}{l}\text { SESI } \\
\text { SENAI } \\
\text { SEBRAESP }\end{array}$ & $\begin{array}{l}\text { A empresa possui conhecimento de que o Senai e o } \\
\text { Sebrae promovem cursos para as empresas, mas não } \\
\text { possui contato com as mesmas. }\end{array}$ \\
\hline ERPLAN & Desconhece a entidade. \\
\hline CIESP & Não possui contato com as entidades. \\
\hline
\end{tabular}

* Empresa 5:

Principal produto: biscoito de polvilho

Idade da empresa: 4 anos

Número de funcionários: 6

Sistema de Produção: semi-artesanal

Fundada há 4 anos, esta empresa possui como único produto fabricado o biscoito de polvilho. O critério de desempenho adotado concentra-se no baixo custo de seu produto. O mercado da empresa é o Estado de São Paulo e a empresa alega ter sentido com o aumento da concorrência local no último ano.

O principal e único produto da empresa data da ocasião da inauguração da empresa (4 anos), e os principais equipamentos da empresa datam do mesmo período. A produção é semi-artesanal, não havendo a utilização de dispositivos com base na microeletrônica. O prédio onde a empresa encontra-se instalada é alugado.

Com relação à sua gestão de recursos humanos, a empresa não oferece nenhum benefício extra a seus funcionários e o empresário alega não haver treinamento de qualificação de funcionários devido à falta de tempo, uma vez que o número de funcionários é bastante reduzido para o atual volume de produção. Na realidade, 
apenas 3 dos 6 funcionários da empresa trabalham no setor produtivo. Os outros 3 realizam o trabalho externo de vendas. Assim, a empresa não possui representantes ou atacadistas e as vendas são realizadas apenas por estes funcionários, sendo que a maior parte dos produtos é vendida a pronta-entrega para bares, armazéns e pequenos supermercados. O transporte é próprio, feito através de peruas conduzidas pelos próprios vendedores.

Com relação à gestão da empresa, a mesma é feita pelo proprietário, que não utiliza qualquer tipo de técnica gerencial; há total desconhecimento de ferramentas de gestão, inclusivo sobre o significado da norma ISO 9000.

Não se realiza qualquer tipo de inspeção durante o processo produtivo e a autorização para o funcionamento da empresa é garantida por um químico que realiza visitas mensais à empresa.

A empresa possui estratégia informal, cujo foco volta-se especificamente para o baixo custo dos produtos, uma vez que a empresa já possui mercados cativos justamente por este motivo.

Com relação à gestão financeira, a captação de recursos para a empresa se dá através da prática de trocas de cheques pré-datados e o empresário se queixa de se sentir marginalizado pela dificuldade encontrada em conseguir empréstimos em entidades financeiras.

Por fabricar apenas um único tipo de produto, a empresa naturalmente não realiza qualquer tipo de pesquisa.

Os fornecedores de matérias-primas da empresa estão localizados no Estado de São Paulo e os mesmos são escolhidos com base no menor preço. Não há qualquer tipo de parceria com fornecedores, embora o proprietário da empresa alega estar satisfeito com a maior parte deles.

Como já comentado, o sistema de produção da empresa é semi-artesanal e os operários estão qualificados a operar em todos os postos de trabalho do setor produtivo.

A empresa não faz qualquer tipo de divulgação do produto e acredita que o mesmo tenha boa aceitação no mercado devido a seu baixo preço, uma vez que a empresa tem como meta as camadas da C, D e E da sociedade. A empresa não utiliza o selo da capital do alimento em seus produtos já que não vê vantagens na utilização. 
Não se tem idéia dentro da empresa do que seria o conceito de cluster. A empresa já participou de parceria de troca de matéria-prima com outra empresa, mas sentiu-se lesada e não gostaria de repetir.

Durante toda a entrevista foi ressaltada a assimetria de poder existente entre as pequenas e as grandes empresas da cidade, principalmente nas ações tomadas pelas entidades locais. Porém, é importante ressaltar a falta de integração desta empresa com as demais empresas do município, além do fato de a empresa não ser filiada a nenhuma associação local, o que aumenta o seu isolamento com relação às demais empresas e diminui o seu acesso a informações.

A Tabela 6.14 resume as impressões do representante desta empresa sobre as entidades locais.

TABELA 6.14: Impressões da Empresa 5 sobre entidades do tecido institucional.

\begin{tabular}{|l|l|}
\hline \multicolumn{1}{|c|}{ Entidade } & \multicolumn{1}{c|}{ Impressão } \\
\hline $\begin{array}{l}\text { Secretaria da Indústria e } \\
\text { Comércio (órgão municipal) }\end{array}$ & Atuação não atinge a empresa. \\
\hline ADIMA & Não possui contato com a entidade. \\
\hline GEAD & Desconhece a entidade. \\
\hline $\begin{array}{l}\text { Sindicato dos trabalhadores } \\
\text { da indústria da alimentação. }\end{array}$ & Não possui contato com a entidade. \\
\hline $\begin{array}{l}\text { Universidades e centros de } \\
\text { pesquisa }\end{array}$ & Não possui contato com as universidades. \\
\hline $\begin{array}{l}\text { SESI } \\
\text { SENAI } \\
\text { SEBRAESP }\end{array}$ & Não possui contato com estas entidades. \\
\hline ERPLAN & Desconhece a entidade. \\
\hline CIESP & Não possui contato com a entidade. \\
\hline
\end{tabular}

\section{* Empresa 6:}

Principal produto: biscoitos de polvilho

Idade da empresa: 50 anos

Número de funcionários: 32

Sistema de Produção: semi-artesanal

Esta empresa, que possui mais de 50 anos de existência, foi adquirida há um ano por dois sócios e muita coisa mudou com relação à pesquisa preliminar realizada 
na mesma. Em primeiro lugar, houve um aumento na diversidade dos produtos fabricados: com a troca de proprietários a empresa passou a investir em duas novas linhas de produtos, que são os salgadinhos de milho e de trigo, além do aumento do volume de produção dos biscoitos de polvilho. Com isso, houve um aumento significativo no faturamento da empresa, além da expansão de seu mercado, que até então atendia apenas o interior do estado de São Paulo e agora passa a investir no desenvolvimento de mercados nos estados de Mato Grosso, Mato Grosso do Sul, Minas Gerais, Bahia e Paraná. A empresa possui 2 caminhões que atendem a $40 \%$ das entregas a serem efetuadas pela empresa, sendo o restante é terceirizado.

A empresa vende apenas no atacado e o interior de São Paulo ainda continua responsável por $80 \%$ das vendas da empresa.

O critério de desempenho adotado está firmado no baixo custo dos produtos, embora a empresa prime pelo bom desempenho nas entregas, conseguindo superar seus concorrentes com um prazo de entrega inferior a 5 dias úteis.

Os empresários afirmam não estarem sentindo aumento de concorrência, mas quanto às exigências dos clientes esta tem aumentado, principalmente em termos de redução no custo e no prazo de entrega.

A idade do principal produto da empresa (biscoito de polvilho) é superior a 40 anos e apesar das melhorias efetuadas na empresa com a mudança de proprietários, não houve qualquer modificação neste produto. $O$ equipamento mais novo da empresa tem por volta de um ano e foi comprado quando da ampliação da mesma. A empresa opera em prédio próprio.

Quanto à gestão da empresa, esta é feita pelos proprietários, que possuem curso superior e, embora com formação distinta da área de administração de empresas, possuem bons conhecimentos das técnicas de gestão. Há a intenção de implementação da ISO 9000 no futuro. Quanto aos recursos humanos, a empresa não oferece nenhum tipo de benefício ou garantias extras para os funcionários e o treinamento dos mesmos é realizado apenas no ato da contratação, embora a empresa esteja estudando a possibilidade de utilizar empresas terceirizadas para qualificar sua mão-de-obra, principalmente em práticas específicas para a indústria de alimentos.

Não há inspetores de qualidade e o controle de qualidade na produção é sensorial e efetuado pelos próprios operadores, embora sem sistematização. 
Não há planejamento formal e os empresários alegam que ainda estão conhecendo o mercado para poder definir com mais segurança o caminho da empresa.

A definição das estratégias da empresa se dá por meio de visita a feiras e a eventos ligados à indústria da alimentação. Já a captação de recursos para a empresa é feita através de recursos do crédito privado, e os empresários alegam não terem encontrado qualquer tipo de dificuldade para consegui-lo.

Quanto ao desenvolvimento de produtos, há alguns meses a empresa contratou um assessor técnico em tempo parcial que vem auxiliando a empresa no desenvolvimento dos salgadinhos de trigo e de milho. Além disso, a empresa pretende a contratação de um engenheiro de alimentos em tempo parcial.

Conforme já citado, o último produto da empresa foi lançado há menos de um ano e os investimentos para maior competitividade são feitos principalmente nas áreas de vendas e distribuição, através da ampliação dos mercados da empresa e inserção em novos canais de distribuição. Para tanto, foi contratado um profissional de vendas bem qualificado e com bastante experiência na comercialização de produtos alimentícios, fato que tem rendido surpreendentes resultados para a empresa.

Quanto ao processo de aquisição de matérias-primas, a empresa preza pelo menor preço, justificando esta opção para a manutenção do baixo preço característico de seu produto.

Não são realizados testes na recepção das matérias-primas e as relações com os fornecedores são apenas comerciais, não havendo parcerias ou outras formas de colaboração. A maioria dos fornecedores da empresa está localizada nos estados de São Paulo e Paraná, e a empresa possui plena confiança em mais de 50\% deles.

Com relação à produção, o sistema é semi-artesanal e há polivalência dos trabalhadores com relação aos postos de trabalho, que estão aptos para trabalhar em qualquer posto das 3 diferentes linhas produtivas da empresa.

Quanto à aceitação do produto no mercado, há uma forte identificação dos clientes com a marca dos produtos, principalmente do biscoito de polvilho, que já se encontra a décadas no mercado. Não são realizadas propagandas do produto. 
A empresa não utiliza o selo "Marília Capital do Alimento" em seus produtos, mas enxerga esta iniciativa como positiva, sobretudo para a divulgação das pequenas empresas, e incorporará o selo em seus produtos nas próximas aquisições de embalagens.

Os empresários nada sabem sobre o conceito de cluster e ainda não participaram de nenhuma forma de cooperação, embora julguem ter bons relacionamentos com os demais empresários do ramo alimentício do município. Eles alegam que participariam de parcerias e de cooperação. As impressões dos dirigentes desta empresa com relação às entidades do tecido institucional da mesma estão resumidas na Tabela 6.15 .

TABELA 6.15: Impressões da Empresa 6 sobre entidades do tecido institucional.

\begin{tabular}{|l|l|}
\hline \multicolumn{1}{|c|}{ Entidade } & \multicolumn{1}{c|}{ Impressão } \\
\hline $\begin{array}{l}\text { Secretaria da Indústria e } \\
\text { Comércio (órgão municipal) }\end{array}$ & Atuação não atinge a empresa. \\
\hline ADIMA & $\begin{array}{l}\text { Reconhece as boas intenções da entidade, mas não possui } \\
\text { contato direto. }\end{array}$ \\
\hline GEAD & Desconhece a entidade. \\
\hline $\begin{array}{l}\text { Sindicato dos trabalhadores } \\
\text { da indústria da alimentação. }\end{array}$ & Nunca teve contato com a entidade. \\
\hline $\begin{array}{l}\text { Universidades e centros de } \\
\text { pesquisa }\end{array}$ & Não possui interação. \\
\hline $\begin{array}{l}\text { SESI, SENAI } \\
\text { SEBRAESP }\end{array}$ & Desconhece as ações destes grupos. \\
\hline ERPLAN & Desconhece a entidade. \\
\hline CIESP & Não possui interação com a entidade. \\
\hline
\end{tabular}

\section{* Empresa 7:}

Principal produto: confeitos de amendoim

Idade da empresa: 7 anos

\section{Número de funcionários: 10}

Sistema de Produção: semi-artesanal

Esta empresa foi fundada dada a saída do proprietário de uma empresa local também produtora de confeitos de amendoim. A experiência adquirida pelo proprietário enquanto funcionário da empresa o capacitou para a abertura de seu 
próprio empreendimento. A empresa compete com base no baixo preço de seus produtos finais com relação aos produtos similares no mercado e possui seus principais clientes na Grande São Paulo e na capital do Estado.

O empresário afirma que recentemente tem sofrido o impacto do aumento da concorrência, que tem investido em melhorias nas embalagens e na divulgação de seus produtos no mercado abrangido por esta empresa.

A idade do principal produto data da inauguração da empresa, embora algumas modificações têm sido realizadas ao longo do tempo no produto principal, levando à criação de outros produtos, que datam de aproximadamente 3 anos.

A empresa opera com equipamentos antigos, adquiridos de segunda-mão na época de sua fundação. Assim, estima-se que o seu principal equipamento tenha aproximadamente 20 anos. O prédio é alugado e não são utilizados dispositivos com base na microeletrônica.

A empresa não oferece incentivos aos seus funcionários e nem são oferecidos treinamentos, exceto quando os mesmos são contratados.

Não são utilizadas técnicas de gestão e o gerenciamento da empresa é feito pelo proprietário, que conta com o auxílio de 3 membros de sua família na produção.

Não são realizados testes de controle de qualidade, não existindo, assim, inspetores de qualidade.

A empresa não possui estratégia formal, alegando fazer o planejamento da empresa apenas no curto prazo (mensal).

Quanto à gestão financeira, quando há necessidade de captação de recursos, a empresa apela para a prática de troca de cheques pré-datados. O empresário afirma haver muita dificuldade em conseguir crédito na praça, principalmente pela falta de bens para serem dados como garantia ao empréstimo.

As pesquisas realizadas são informais e executadas pelo próprio dono da empresa e o desenvolvimento dos novos produtos ocorrido há 3 anos foi realizado a partir da cópia de produtos já existentes no mercado e feito na base de "tentativas e erros".

A maior razão para a escolha de fornecedores é o preço da matéria-prima e os mesmos encontram-se localizados nos estados de São Paulo e Paraná. 
Não são realizadas parcerias com os fornecedores e a empresa encontra-se satisfeita com o desempenho dos mesmos.

A empresa opera em sistema de produção semi-artesanal e há definição estreita dos operadores com relação aos postos de trabalho.

A empresa vende exclusivamente no atacado e o transporte dos produtos é feito pelos próprios vendedores, no sistema de pronta-entrega para bares, armazéns e pequenos supermercados.

Não há investimentos em propaganda e a empresa não utiliza o selo da capital do alimento. $\mathrm{O}$ empresário credita o sucesso de suas vendas ao sistema de visitas aos clientes com o sistema de pronta-entrega.

Não há, por parte do proprietário, conhecimento sobre o que vem a ser um cluster. A empresa não participa de nenhuma forma de colaboração com seus concorrentes, afirmando haver uma concorrência bastante acirrada entre os mesmos, uma vez que a maioria deles disputa o mesmo mercado.

A empresa ressalta a assimetria de poder existente no município, crendo que as ações das instituições estejam mais voltadas para as empresa de maior porte. A opinião do representante da empresa sobre as instituições locais está resumida na Tabela 6.16.

TABELA 6.16: Impressões da Empresa 7 sobre entidades do tecido institucional.

\begin{tabular}{|l|l|}
\hline \multicolumn{1}{|c|}{ Entidade } & \multicolumn{1}{c|}{ Impressão } \\
\hline $\begin{array}{l}\text { Secretaria da Indústria e } \\
\text { Comércio (órgão municipal) }\end{array}$ & Ações não afetam a empresa. \\
\hline ADIMA & Não possui contato com a entidade \\
\hline GEAD & Desconhece a entidade. \\
\hline $\begin{array}{l}\text { Sindicato dos trabalhadores } \\
\text { da indústria da alimentação. }\end{array}$ & Não possui contato \\
\hline $\begin{array}{l}\text { Universidades e centros de } \\
\text { pesquisa }\end{array}$ & Não possui contato. \\
\hline $\begin{array}{l}\text { SESI } \\
\text { SENAI } \\
\text { SEBRAESP }\end{array}$ & $\begin{array}{l}\text { Sabe das ações do Sebrae na promoção de cursos e } \\
\text { palestras para empresários, mas a empresa ainda não } \\
\text { participou de nenhum deles. }\end{array}$ \\
\hline ERPLAN & Desconhece a entidade. \\
\hline CIESP & Ações não afetam a empresa. \\
\hline
\end{tabular}




\section{* Empresa 8}

Principal produto: confeitos de amendoim

Idade da empresa: 16 anos

Número de funcionários: 29

Sistema de Produção: massa

Esta empresa foi fundada por dois irmãos, graças à experiência adquirida trabalhando em uma empresa local atuante no mesmo setor. Um dos proprietários cuida da parte comercial do empreendimento e outro dos assuntos relativos à produção. $\mathrm{O}$ custo dos produtos tem sido a principal meta dos empresários, embora os mesmos também primem pela qualidade do produto, visando atingir as camadas B e C da sociedade.

A idade do principal linha produtos da empresa (confeitos de amendoim) data da fundação da mesma, sendo estes responsáveis por $70 \%$ do faturamento da empresa. Os outros $30 \%$ do faturamento estão relacionados aos salgadinhos de trigo e aos confeitos de açúcar. O equipamento mais importante da empresa tem 10 anos.

As vendas da empresa destinam-se para praticamente todo o território nacional e a distribuição dos mesmos é feito por transporte terceirizado. As vendas são realizadas por atacadistas. Os proprietários queixam-se dos altos custos dos fretes e da inadimplência dos clientes.

Não há uso de dispositivos com base na microeletrônica e o prédio da empresa é alugado.

Conforme já comentado, a administração da empresa é feita por seus proprietários, que não possuem formação específica na área de administração, desconhecendo, assim, técnicas de gestão como CEP, JIT, ISO 9000, entre outras.

Além disso, não são executados com freqüência testes ou controles na linha produtiva e não há inspetores de qualidade.

Não há estratégia formal e a base da competitividade da empresa está centrada no custo dos produtos, uma vez que não são realizadas propagandas para a divulgação dos mesmos. A empresa não utiliza em suas embalagens o selo da capital do alimento. 
Os recursos financeiros para a empresa são conseguidos através de empréstimos bancários.

A pesquisa para o desenvolvimento de novos produtos são realizadas pelos proprietários, que os testam na própria linha de produção e o último lançamento da empresa data de 3 anos.

Os fornecedores da empresa são escolhidos com base na melhor qualidade, embora a empresa não realize testes de recebimento de materiais. A maioria dos fornecedores está localizada nos estados de São Paulo e Paraná, sendo que o sal é proveniente do estado do Rio Grande do Norte. Os empresários mostram-se satisfeitos com seus fornecedores, embora se queixem da falta de fornecedores locais ou regionais, o que poderia ser uma fonte de redução dos custos de transporte.

O sistema de produção da empresa é em massa, havendo estreita definição da maioria dos postos de trabalho dos operadores.

A empresa não participa e nem tem interesse em participar de cooperação com seus concorrentes, alegando ser este um mercado bastante concorrido dada a quantidade de empresas locais concorrendo com os mesmos produtos. Não há idéia do que vem a ser um cluster.

Quanto à assimetria de poder, os empresários não souberam julgar o fato e as suas impressões sobre as entidades locais encontram-se resumidas na Tabela 6.17.

TABELA 6.17: Impressões da Empresa 8 sobre entidades do tecido institucional.

\begin{tabular}{|l|l|}
\hline \multicolumn{1}{|c|}{ Entidade } & \multicolumn{1}{c|}{ Impressão } \\
\hline $\begin{array}{l}\text { Secretaria da Indústria e } \\
\text { Comércio (órgão municipal) }\end{array}$ & Ações não afetam a empresa. \\
\hline ADIMA & Não possui contato com a entidade. \\
\hline GEAD & Ações não afetam a empresa. \\
\hline $\begin{array}{l}\text { Sindicato dos trabalhadores } \\
\text { da indústria da alimentação. }\end{array}$ & Não possui contato com a entidade. \\
\hline $\begin{array}{l}\text { Universidades e centros de } \\
\text { pesquisa }\end{array}$ & Não possui contato com as universidades. \\
\hline $\begin{array}{l}\text { SESI } \\
\text { SENAI } \\
\text { SEBRAESP }\end{array}$ & Participa de cursos e palestras promovidos pelo Sebrae. \\
\hline ERPLAN & \\
\hline CIESP & Desconhece a entidade. \\
\hline
\end{tabular}


* Empresa 9:

Principal produto: pipoca (diversos tipos)

Idade da empresa: 18 anos

Número de funcionários: 3

Sistema de Produção: artesanal

Esta empresa familiar conta com os membros da família para a sua operação. Apenas 1 dos funcionários não pertence à família e o sistema de produção praticado é artesanal. A empresa compete com seus produtos no mercado local, vendendo seus produtos para pequenos comércios localizados no município, como bares, cantinas escolares e mini-mercados. O transporte de mercadorias é feito por uma perua de propriedade da empresa.

O seu principal produto data do surgimento da empresa (18 anos), e são poucos e bastante simples os equipamentos utilizados em sua operação. O prédio da empresa é uma extensão da residência do proprietário.

Não são dados benefícios aos funcionários e o treinamento é executado apenas quando há a mudança de algum funcionário. Há um desconhecimento total das técnicas de gestão e não se realiza controle de qualidade no setor produtivo.

Desta forma, não há estratégia formal e não se realiza propaganda dos produtos. Acredita-se que as vendas dos produtos sejam asseguradas pelos baixos custos do produto e pelo sistema de pronta-entrega.

O último lançamento de produto da empresa se deu há 5 anos, sendo este uma variação dos produtos já fabricado pela empresa. Apenas um dos fornecedores de matéria-prima da empresa se localiza na cidade de Marília, sendo que as demais matérias-primas são provenientes do interior do estado de São Paulo e dos estados de Goiás e Paraná.

A empresa encontra-se satisfeita com seus fornecedores, embora reclame da distância de suas plantas.

Quanto ao setor produtivo, há polivalência nas tarefas executadas pelos funcionários, mesmo porque o trabalho executado é bastante simples. 
A empresa utiliza o selo da capital do alimento e acha importante este modo de divulgação do município e de suas empresas, embora seu mercado esteja restrito apenas ao município.

A empresa participa de cooperação $\mathrm{cm}$ outras empresa do ramo, cooperação esta restrita à troca de matérias-primas quando há falta da mesma.

O empresário já ouviu falar em cluster, mas não sabe do que se trata e afirma que participaria de outras formas de cooperação com empresas concorrentes.

TABELA 6.18: Impressões da Empresa 9 sobre entidades do tecido institucional.

\begin{tabular}{|c|c|}
\hline Entidade & Impressão \\
\hline $\begin{array}{l}\text { Secretaria da Indústria e } \\
\text { Comércio (órgão municipal) }\end{array}$ & Nunca se beneficiou de ações da entidade. \\
\hline ADIMA & $\begin{array}{l}\text { Possui contato constante com a entidade, se beneficiando } \\
\text { da mesma com a troca de informações e através de } \\
\text { eventuais intermediações com outras empresas. }\end{array}$ \\
\hline GEAD & Ações não afetam a empresa. \\
\hline $\begin{array}{l}\text { Sindicato dos trabalhadores } \\
\text { da indústria da alimentação. }\end{array}$ & Não possui contato com a entidade. \\
\hline $\begin{array}{l}\text { Universidades e centros de } \\
\text { pesquisa }\end{array}$ & Não possui contato. \\
\hline $\begin{array}{l}\text { SESI } \\
\text { SENAI } \\
\text { SEBRAESP }\end{array}$ & $\begin{array}{l}\text { Participa com freqüência de cursos promovidos pelo } \\
\text { Sebrae e Senai. }\end{array}$ \\
\hline ERPLAN & Desconhece a entidade. \\
\hline CIESP & Participa de debates e palestras promovidos. \\
\hline
\end{tabular}

\section{* Empresa 10:}

Principal produto: achocolatados

Idade da empresa: 34 anos

Número de funcionários: 25

Sistema de Produção: semi-artesanal

Esta empresa possui sua trajetória recente parecida com a empresa 6. Era uma empresa familiar que foi recentemente ( 2 anos) adquirida por dois sócios, que hoje são os administradores da empresa. Esta mudança, aliada a investimentos realizados 
para a ampliação da carta de clientes e das linhas já existentes, levou a empresa a aumentar em $200 \%$ seu faturamento. A empresa opera em prédio próprio.

O principal produto fabricado pela empresa se constitui na linha de achocolatados e atualmente as vendas do mesmo no atacado destinam-se aos estados de São Paulo, Mato Grosso, Mato Grosso do Sul, Paraná e Roraima. A empresa também comercializa seus produtos no varejo, existindo 17 vendedores autônomos responsáveis por este processo.

O principal critério de desempenho adotado pela empresa centra-se no custo dos produtos, que visam o atendimento das camadas menos favorecidas da sociedade. A empresa tem sentido bastante o aumento da concorrência nacional, mas isso não tem afetado suas operações, haja visto a sua recente expansão de mercados.

Há uma pressão dos clientes para aumento da qualidade dos produtos e concomitante abaixamento de preços, constituindo em um desafio para a empresa em questão.

O principal produto da empresa tem mais de 20 anos e o produto mais recente foi lançado há um ano e meio. Quanto aos equipamentos utilizados pela empresa, a máquina mais recente foi adquirida há um ano e a microeletrônica está presente apenas neste equipamento.

Quanto à gestão de recursos humanos, a empresa não oferece nenhum tipo de benefício a seus funcionários e o treinamento de pessoal só é realizado no ato da contratação.

Embora um dos atuais dirigentes da empresa tenha formação superior em Administração de Empresas, este não faz uso de técnicas gerenciais, operando de maneira semi-artesanal, embora a empresa pretenda, no futuro, obter o certificado ISO 9000.

Não são realizadas análises físico-químicas nos produtos da empresa. O controle é apenas visual, realizado pelo supervisor da produção. Portanto, não há inspetores de qualidade.

Os dirigentes da empresa alegam possuir estratégia formal, sendo esta fortemente calcada no custo dos produtos. A definição da estratégia se dá pela percepção do mercado obtida pelos sócios-proprietários. 
A empresa atende apenas o mercado interno e a captação de recursos financeiros é feita através da prática da troca de cheques pré-datados.

Não são realizadas pesquisas para o desenvolvimento de novos produtos e o último produto foi lançado através de adaptações de um produto já existente. Os investimentos para maior competitividade estão sendo feitos na melhoria das embalagens dos produtos e no investimento na ampliação dos mercados da empresa.

A escolha de fornecedores é feita sob o critério do menor custo de matériasprimas e não são realizados testes no recebimento destes materiais. Os fornecedores da empresa estão localizados em sua maioria na cidade de São Paulo e no estado do Paraná, não havendo fornecedores locais. Os empresários encontram-se satisfeita com seus fornecedores, apesar de não realizar qualquer tipo de parceria com os mesmos. O modelo de produção adotado pela empresa é semi-artesanal e há polivalência na definição dos postos de trabalho.

Com relação ao marketing, não são realizadas propagandas para a divulgação de seus produtos, e seus dirigentes acreditam haver uma forte identificação dos clientes com a marca do produto, além dos preços atrativos apresentados por estes. $\mathrm{O}$ selo "Marília Capital do Alimento" é utilizado nas embalagens dos produtos da empresa.

Os empresários alegam conhecimento sobre o que vem a ser um cluster e sobre de suas vantagens, e um destes dirigentes dirige uma das entidades de classe do município, trabalhando ativamente na divulgação da cidade como centro regional na produção de alimentos. Mediante esta questão, a empresa participa constantemente de pactos de cooperação com outros empresários locais, até mesmo com concorrentes, no empréstimo de produtos e na divisão dos custos relativos ao transporte dos mesmos.

Na opinião dos empresários, o ambiente institucional do município é marcado por uma assimetria de poder, onde as grandes empresas possuem maior acesso aos recursos destinados à produção industrial do município.

A Tabela 6.19 sintetiza as impressões destes empresários com relação às entidades presentes neste ambiente. 
TABELA 6.19: Impressões da Empresa 10 sobre entidades do tecido institucional.

\begin{tabular}{|c|c|}
\hline Entidade & Impressão \\
\hline $\begin{array}{l}\text { Secretaria da Indústria e } \\
\text { Comércio (órgão municipal) }\end{array}$ & $\begin{array}{l}\text { Embora a empresa não utilize os benefícios, foi } \\
\text { destacada a atuação desta entidade na promoção do } \\
\text { chamado Banco do Povo, que promove, de forma } \\
\text { simplificada, empréstimos de até } 5 \text { mil reais para } \\
\text { pequenos empresários. }\end{array}$ \\
\hline ADIMA & $\begin{array}{l}\text { Promoção de consórcios para participação em feiras e } \\
\text { intermediação de negócios junto às empresas locais. }\end{array}$ \\
\hline GEAD & $\begin{array}{l}\text { Reconhece a importância de seus trabalhos como } \\
\text { articulador de benefícios para as empresas, embora a } \\
\text { entidade favoreça em especial as grandes empresa, } \\
\text { justamente pela amplitude das questões discutidas por } \\
\text { esta entidade. }\end{array}$ \\
\hline $\begin{array}{l}\text { Sindicato dos trabalhadores } \\
\text { da indústria da alimentação. }\end{array}$ & Ainda não teve contato com as ações da entidade. \\
\hline $\begin{array}{l}\text { Universidades e centros de } \\
\text { pesquisa }\end{array}$ & sui contato com as entidades de ensino. \\
\hline $\begin{array}{l}\text { SESI } \\
\text { SENAI } \\
\text { SEBRAESP }\end{array}$ & $\begin{array}{l}\text { Os empresários vêem no Senai e Sebrae fontes de } \\
\text { reciclagem para as empresas, sendo o primeiro } \\
\text { responsável pela capacitação de profissionais e o segundo } \\
\text { como exemplo de apoio em consultorias e cursos } \\
\text { especializados. }\end{array}$ \\
\hline ERPLAN & Desconhece a entidade. \\
\hline CIESP & Não possui contato com a entidade. \\
\hline
\end{tabular}

\subsubsection{Considerações sobre os dados da análise interna}

A tabela 6.19 sintetiza os dados coletados na pesquisa de campo realizada junto às dez MPE's do cluster. A seqüência de fatores analisados obedece à mesma disposição adotada na metodologia de pesquisa.

Ressalta-se, aqui, a homogeneidade encontrada nas características destas empresas, fator este que facilita a análise do conjunto. 
TABELA 6.20: Dados da pesquisa coletados para a análise interna

\begin{tabular}{|c|c|}
\hline Fator analisado & Resultado dos dados coletados nas empresas \\
\hline Origem da empresa & $\begin{array}{l}8 \text { das empresas pesquisadas possuem sua origem vinculada à ampliação de } \\
\text { um negócio familiar existente. }\end{array}$ \\
\hline $\begin{array}{l}\text { Critério } \\
\text { desempenho }\end{array}$ & $\begin{array}{l}\text { Todas as empresas possuem como critério de desempenho o custo de } \\
\text { seus produtos. }\end{array}$ \\
\hline Planejamento & Nenhuma das empresas possui plane jamento estratégico formalizado. \\
\hline Recursos humanos & $\begin{array}{l}\text { Nenhuma das empresas entrevistadas concede garantias ou benefícios a } \\
\text { seus funcionários nem realiza treinamentos com os mesmos. Além disso, } \\
\text { nenhuma delas conta com a atuação permanente de profissionais com } \\
\text { nível superior especializados na área de alimentos. }\end{array}$ \\
\hline $\begin{array}{l}\text { Administração da } \\
\text { qualidade }\end{array}$ & $\begin{array}{l}\text { Não há laboratórios de análises físico-químicas ou microbiológicas nestas } \\
\text { empresas e nenhuma delas realiza testes em suas matérias-primas ou } \\
\text { produtos acabados. }\end{array}$ \\
\hline Gestão financeira & $\begin{array}{l}90 \% \text { das empresas pesquisadas possuem dificuldades para a obtenção de } \\
\text { crédito junto à iniciativa privada. }\end{array}$ \\
\hline$P \& D$ & $\begin{array}{l}\text { Nenhuma das empresas realiza pesquisa e desenvolvimento de novos } \\
\text { produtos. Em } 90 \% \text { das empresas o principal produto possui idade igual ou } \\
\text { superior a } 5 \text { anos. Os produtos identificados com idade inferior a esta } \\
\text { constituem-se, na sua maioria, em adaptações ou variações de produtos } \\
\text { já existentes nas empresas. }\end{array}$ \\
\hline $\begin{array}{l}\text { Logística } \\
\text { aquisições }\end{array}$ & $\begin{array}{l}\text { Nenhuma das empresas realiza parcerias com seus fornecedores e a } \\
\text { escolha dos mesmos se baseia em custo para a totalidade das empresas } \\
\text { pesquisadas. }\end{array}$ \\
\hline Produção & $\begin{array}{l}\text { Os sistemas de produção artesanal ou semi-artesanal prevalecem em } \\
90 \% \text { das empresas pesquisadas. }\end{array}$ \\
\hline $\begin{array}{l}\text { Logística } \\
\text { distribuição } \\
\text { mercados }\end{array}$ & $\begin{array}{l}\text { Apenas } 20 \% \text { das empresas pesquisadas possuem mercado a cidade de } \\
\text { Marília e a sua região. As demais comercializam seus produtos por vários } \\
\text { Estados do território nacional. Nenhuma das empresas exporta seus } \\
\text { produtos. Devido a estas empresas operarem com sua capacidade } \\
\text { produtiva máxima, o tempo de atendimento aos pedidos nunca é inferior a } \\
\text { uma semana, sendo que uma das empresas alegou levar até } 15 \text { dias para } \\
\text { atender a um pedido. }\end{array}$ \\
\hline Marketing & $\begin{array}{l}\text { Nenhuma das empresas realiza propaganda de seus produtos e 50\% } \\
\text { utilizam o selo "Marília Capital Nacional do Alimento" em embalagens. }\end{array}$ \\
\hline $\begin{array}{l}\text { Impressões das } \\
\text { empresas sobre as } \\
\text { entidades }\end{array}$ & $\begin{array}{l}\text { De modo geral, maioria das empresas vê pouca colaboração por parte das } \\
\text { entidades do tecido institucional do cluster, sendo sua relação com estas } \\
\text { bastante fraca. }\end{array}$ \\
\hline
\end{tabular}

As características apresentadas por este grupo de empresas estão bastante congruentes com os pontos que caracterizam as MPE's levantados na revisão bibliográfica deste trabalho. Estas empresas operam sem a realização de $P \& D$, não havendo, assim, inovação, sendo a maioria dos produtos deste conjunto de empresas cópias de produtos lançados por empresas de maior destaque atuantes no mesmo mercado. 
Além disso, ressalta-se o seu gerenciamento familiar, com a baixa capacitação de seu pessoal, tanto do nível operacional quanto do nível administrativo. Esta falta de profissionalismo na condução dos negócios leva ao uso restrito ou inexistente de técnicas gerenciais, além da redução de seus horizontes de planejamento para o curto-prazo.

A falta de bens materiais a serem envolvidos como garantias para a aquisição de empréstimos, faz com estas empresas tenham dificuldades para a obtenção de recursos financeiros. Desse modo, mesmo tendo oportunidades para o ingresso em novos mercados, como é o caso de algumas empresas analisadas, elas acabam sendo penalizadas pela falta de capital para expandir o empreendimento. Isto acarreta a restrição aos mercados já abrangidos pela empresa, além da obsolescência dos equipamentos utilizados no processo produtivo.

Assim, prevalece o modo de produção semi-artesanal, com baixos investimentos em treinamento de funcionários e em melhorias no processo produtivo. Vale lembrar que a produção de alimentos requer cuidados especiais durante o processo produtivo e, de acordo com os dados levantados, nenhuma das empresas realiza testes para o controle tanto físico-químico quanto microbiológico das matérias-primas e dos produtos fabricados.

Um ponto interessante destas empresas está relacionado à falta de crédito que as mesmas depositam nas ações desempenhadas pelas entidades do tecido institucional. Isto se constitui em um ponto negativo, já que, para que sejam aproveitadas todas as vantagens de um cluster, a interação entre empresas e instituições locais se faz muito importante.

\section{* Desempenho das empresas em termos dos fatores competitivos}

Conforme definido na revisão bibliográfica realizada, para atingir os fatores competitivos definidos a partir das atuais exigências do mercado, uma empresa necessita possuir estrutura e infra-estrutura configuradas a permitir a realização de suas atividades para atingir a qualidade de seus produtos, possuir programas de redução de custos, desempenho adequados nas entregas, além de flexibilidade e 
inovação para atender às variações na demanda, alcançando de forma adequada a satisfação dos clientes.

Pelo resultado do desempenho destas empresas com relação à condução das atividades da cadeia de valor, percebe-se que elas apresentam deficiências para o alcance destes fatores. Ficou claro que estas empresas competem baseadas no baixo custo de seus produtos. Porém, para o alcance deste fator, não foi verificado nenhum tipo de ação sistematizada, como a realização de pesquisas nos produtos que promovam a redução de seu custo, por exemplo. O baixo preço do produto é garantido pela compra de matérias-primas de fornecedores que oferecem o menor preço do mercado.

O mesmo se dá com relação à qualidade dos produtos. A empresa não investe em sistemas de controle ou garantia de qualidade, não sendo realizados controles fisico-químicos ou microbiológicos nas matérias-primas adquiridas e nem mesmo nos produtos acabados. Desta maneira, a padronização dos lotes produzidos fica comprometida por eventuais variações tanto nas matérias-primas utilizadas quanto nas etapas dos processos que geram os produtos finais. Além disso, a maioria das empresas pesquisadas desconhece as normas ISO 9000 e outras ferramentas administrativas importantes para a garantia e a manutenção dos parâmetros do processo produtivo.

De acordo com a proposição inicial deste trabalho, as MPE's do cluster apresentam baixa capacidade de inovação tanto de seus produtos quanto de seus processos e gestão, fator este que afeta negativamente sua competitividade. Neste sentido, apenas duas das empresas pesquisadas realizam pesquisas visando o desenvolvimento de novos produtos. Porém, estas são realizadas de maneira não sistematizada, efetuadas no próprio setor produtivo e na base em 'tentativas e erros'. Não existem laboratórios para esta finalidade e nenhuma das empresas possui um profissional qualificado em processamento de alimentos atuando em tempo integral. Todas elas possuem um profissional qualificado, mas suas responsabilidades nas empresas se restringem à obtenção do alvará para seus funcionamentos, sendo suas atuações limitadas a visitas mensais às mesmas.

Quanto à flexibilidade das linhas produtivas, este fator possui uma influência menor para este grupo de empresas, uma vez que a maioria delas trabalha com linhas 
dedicadas à fabricação de produtos específicos, não havendo, assim, importância maior deste fator para este conjunto.

Com relação ao desempenho nas entregas, destaca-se que todas as empresas pesquisadas afirmaram operar atualmente com sua capacidade máxima de produção, comprometendo o tempo de atendimento aos pedidos, que nunca é menor do que uma semana. Este se apresenta como um fator preocupante, já que o tempo de atendimento a pedidos se constitui em uma variável fundamental em tempos de estoques reduzidos.

Assim, nota-se que o desempenho destas empresas com relação aos fatores competitivos definidos por esta nova era empresarial é bastante deficiente. Acrescenta-se a isso o fato destas empresas possuírem baixa expectativa de realização de futuros investimentos para a promoção de ações que levem a um melhor desempenho destes fatores, uma vez que as mesmas possuem dificuldades financeiras para a realização de melhorias em suas plantas fabris. Além disso, destacam-se a dificuldade de se conseguir crédito junto à iniciativa privada e o gerenciamento familiar que, via de regra, se caracteriza pela falta de crédito nas técnicas gerenciais.

Porém, apesar das adversidades encontradas, estas empresas possuem mercados cativos, já que, mesmo não realizando propagandas de divulgação, muitas delas encontram-se atualmente com possibilidades de expansão de seus negócios. Acredita-se que o diferencial destas empresas esteja no baixo custo de seus produtos, uma vez que operam em mercados não explorados pelas empresas líderes, atendendo às camadas menos favorecidas da sociedade.

Acrescenta-se, porém, que estas empresas não apresentam qualquer diferenciação em seus produtos e, de acordo com Porter (1990), competir com base em custos não se apresenta como uma estratégia sustentada.

Assim, as pressões do mercado por produtos e serviços que de fato atendam às suas necessidades e o risco da entrada de outras empresas mais qualificadas neste mercado se constituem em ameaças potenciais à existência destas empresas. 


\subsubsection{Desempenho das empresas com relação aos fatores de cooperação}

1. Informacão: apenas uma das empresas pesquisadas possui conhecimentos sobre o conceito de cluster e das vantagens que podem ser auferidas para as empresas nele presentes. A falta de informação sobre os benefícios da concentração geográfica de empresas do mesmo setor compromete as ações que eventualmente venham a ser tomadas para beneficiar este conjunto de empresas.

2. Confianca: duas das empresas pesquisadas afirmam não possuírem confiança em seus fornecedores e concorrentes. As demais afirmam confiarem nas empresas presentes no cluster bem como nas empresas fornecedoras.

3. Colaboração: dentre as empresas pesquisadas, duas delas alegam que não realizariam parcerias com empresas que atuam no mesmo setor, alegando que já foram prejudicadas em parcerias realizadas anteriormente. Este se constitui em um fator bastante desfavorável, uma vez que a confiança perdida é muito difícil de ser reconquistada.

4. Governanca: As parcerias realizadas entre as empresas pesquisadas restringemse à troca de matérias-primas e ao rateio de fretes entre empresas do mesmo setor. Desta maneira, a estrutura de governança se restringe às empresas participantes, e se baseia na relação existente entre as duas empresas envolvidas.

\subsubsection{Considerações sobre os fatores de cooperação}

Ao contrário da proposição inicial apresentada por este trabalho, estas empresas se apresentarem relativamente favoráveis à cooperação, apesar do reduzido número de iniciativas tomadas com este objetivo. Além disso, as iniciativas de colaboração levantadas mostram-se insuficientes para a promoção de vantagens competitivas para este conjunto de empresas. 
Para isso, seria necessária uma maior interação entre estas empresas, que deveriam trocar, além de matérias-primas, informações, com o compartilhamento de objetivos em comum.

Ressalta-se, porém, que a falta de conhecimentos sobre os reais benefícios da cooperação impera neste conjunto de empresas, dificultando a existências de iniciativas mais robustas neste sentido, conforme a proposição apresentada no início deste trabalho.

\subsubsection{Análise externa}

Aqui estão analisadas as características relativas ao ambiente institucional do cluster alimentício de Marília. Os dados necessários para esta análise foram coletados a partir de entrevistas realizadas nas seguintes entidades: Adima, Sebrae, Secretaria da Indústria e Comércio, Sesi e Fundação de Ensino "Eurípides Soares da Rocha".

Inicialmente é realizada uma breve descrição da atuação de cada uma das instituições e identificadas as ações das mesmas específicas para as MPE's do setor alimentício. $\mathrm{Na}$ sequência, as características do ambiente institucional estão discutidas de acordo com a estrutura de tópicos proposta na metodologia deste trabalho.

E, por fim, são tecidas algumas considerações sobre esta análise do ambiente institucional.

\section{Breve descricão da atuacão das instituicões locais}

\section{Secretaria da Indústria e Comércio:}

Órgão público que atende a toda a comunidade empresarial (indústria e comércio), trabalhando afinada com o CIESP, a Adima e a Associação Comercial.

Possui atuação como poder público no incentivo à instalação, ampliação e desenvolvimento industrial através dos distritos industriais do município. 
As ações desta entidade são permanentes e não específicas. Cede áreas e oferece os recursos do município (terraplanagem, assessoria, entre outros). Atua permanentemente em contato com os empresários da cidade, resolvendo impasses e carências dos mesmos. Foi por meio desta entidade que se instalou o Banco do Povo no município, que, através de recursos financeiros da Caixa Econômica Estadual, oferece financiamentos limitados à faixa de $\mathrm{R} \$ 200,00$ a $\mathrm{R} \$ 5.000,00$ com juros de $1 \%$ ao mês para pessoas físicas que pretendem se dirigir para a área empresarial através da abertura de um pequeno negócio. Estes empréstimos são restritos para empresas que possuem suas atividades voltadas para o setor fabril.

Não existem ações específicas para as empresas da área de alimentos, nem direcionadas para MPE's processadoras de alimentos.

\section{$\checkmark \quad$ Adima:}

Esta associação nasceu para agrupar as empresas de alimentos do município, uma vez que as mesmas possuem propósitos e anseios específicos do setor, promovendo, assim, o fomento e a alavancagem do mesmo.

Esta entidade possui suas ações direcionadas ao desenvolvimento e divulgação do slogan "Marília Capital Nacional do Alimento", fazendo esta divulgação através de outdoors e painéis (back lights) espalhados em pontos estratégicos do município, adesivos e também através de incentivos às empresas locais para a utilização do selo em suas embalagens Este slogan já foi inclusive oficializado pela Prefeitura Municipal da cidade. Atualmente, ela possui seus esforços direcionados no sentido de formalização do selo de origem para os produtos alimentícios de Marília junto aos órgãos competentes.

Além disso, a Adima tem se mostrado bastante atuante na intermediação de trocas de matérias-primas e de conhecimentos tecnológicos entre as empresas a ela associadas, atuando também com a prestação de serviços de consultoria e assessoria às afiliadas, através de parcerias com outras entidades locais, como o Senai e Sebrae.

Uma outra ação desta entidade que merece destaque é a articulação para garantir a participação de empresas do setor na Fispal, importante feira internacional das áreas de embalagens e tecnologia que ocorre em São Paulo. No ano de 2002, a 
entidade formou um consórcio onde 9 empresas do setor conseguiram participar do evento, através do rateio de despesas de um único espaço intitulado com o slogan do município. Assim, empresas com menores possibilidades financeiras puderam ter acesso à feira, divulgando os seus produtos. A Adima espera repetir a realização deste feito no ano de 2003, e buscará que mais empresas participem do evento.

\section{$\checkmark \quad$ Sindicato da Indústria da Alimentação:}

Esta entidade atua na fiscalização de normas técnicas em defesa do trabalhador, tais como segurança do trabalho, condições sanitárias, entre outras. Atua também na promoção eventual de cursos de preparação de mão-de-obra, voltados especificamente para a área de alimentação. Com relação às MPE's, entretanto, não foi identificada nenhuma ação específica.

\section{$\checkmark \quad$ Fundacão de Ensino "Eurípides S. Rocha":}

A instituição promove de eventos voltados para empresas, fornecendo com frequiência seu espaço físico para a realização de palestras e workshops, como é o caso da April Fest, feira voltada para a promoção da indústria e comércio local. Além disso, a instituição capacita profissionais para a atuação em diversas áreas do conhecimento administrativo, tendo, inclusive, um curso de pós-graduação específico para a gestão agroindustrial, voltado para a reciclagem do pessoal que atua nos níveis administrativos de empresas alimentícias. A instituição também fornece estagiários para a indústria alimentícia local.

Como ação específica para as MPE's, a Fundação promove, atualmente, pesquisas na área de comércio exterior, visando diagnosticar as potencialidades das pequenas empresas para a exportação de seus produtos.

\section{$\checkmark \quad$ Unimar:}

Dada a vocação da cidade para a produção de produtos alimentícios, a universidade abriu o curso de Engenharia de Alimentos, visando formar profissionais 
específicos para o processamento destes produtos. Assim, a referida universidade atua na promoção cursos, semanas e debates sobre processamento de alimentos, favorecendo toda a comunidade empresarial. A instituição também fornece estagiários para as empresas locais. Não foi identificada nenhuma ação específica para as MPE's.

\section{$\checkmark \quad \underline{\text { Ciesp }}$}

Este órgão trabalha bastante afinado com a Adima, que se constitui no braço desta instituição no que tange as empresas de alimentos. Portanto, as ações específicas voltadas tanto para as empresas alimentícias quanto para as empresas de menor porte são colocadas em prática pela Adima.

\section{$\checkmark \quad \underline{\text { Erplan }}$}

Ligado à Secretaria de Desenvolvimento Econômico Estadual, esta instituição trabalha na reunião de dados e políticas para o desenvolvimento econômico regional. Este órgão é mantido pelo orçamento público estadual.

Não possui nenhuma ação voltada especificamente às MPE's de alimentos, nem interação com as outras instituições do município.

\section{$\checkmark \quad \underline{\text { Sebrae }}$}

Esta instituição teve uma participação decisiva na realização da etapa preliminar desta pesquisa, facilitando o acesso às empresas para a aplicação dos questionários. Assim, esta entidade se responsabilizou pela divulgação dos dados coletados para a comunidade empresarial do município, através de um seminário realizado para esta finalidade, que contou com a participação de 29 empresários da indústria alimentícia.

Além disso, através das informações das carências das empresas pesquisadas apresentadas na referida pesquisa, esta instituição já direcionou suas ações no sentido de apoiar as MPE's locais na resolução de seus problemas específicos. 
Desta forma, unindo-se a outras entidades locais, como a Adima, o Senai e o Ciesp, o Sebrae promoveu nos meses de novembro e dezembro último o Sebraetec. Este projeto se constitui em oficinas tecnológicas visando o fornecimento de respaldo técnico sobre como investir em embalagens de produtos alimentícios e sobre como dispor equipamentos e utilizar espaços físicos (lay-out) na área de produção. Estas oficinas foram gratuitas e contaram com aulas ministradas por engenheiros do Senai, especializados nas referidas áreas, com o objetivo de capacitar estas empresas no que tange estes problemas específicos.

Destaca-se também sua participação decisiva na organização e divulgação curso de Boas Práticas na Produção de Alimentos, realizado em parceria com a Adima e o Senai.

\section{$\checkmark \quad \underline{\text { Senai }}$}

Esta instituição, através de parceria com o Sebrae e a Adima, realizou no ano de 2002 o curso de Boas Práticas na Produção de Alimentos, que foi oferecido a todas as empresas produtoras de alimentos do município, visando capacita-las a trabalhar de acordo com a chamada APPCC (Análise de Perigos e Pontos Críticos de Controle), que se constitui de normas que visam garantir confiabilidade, segurança e qualidade na produção de alimentos.

A instituição já ministrou, em parceria com a Adima, cursos para profissionais das pequenas empresas em diversas áreas do setor alimentício, como tecnologia em panificação, confeitaria, entre outros. Atualmente estes cursos vêm sendo aperfeiçoados e devem estar sendo ministrados ainda no primeiro semestre de 2003.

\section{$\checkmark \quad \underline{\text { Sesi }}$}

Em parceria com a Adima, esta instituição trabalha atualmente com um projeto para a implantação de uma cozinha experimental a ser utilizada como piloto pelas pequenas empresas para pesquisas de novos produtos.

Mas devido a outras ações que são prioritárias para a entidade, este projeto ainda não foi colocado em prática. 


\section{Redes de poder territoriais}

Pelas entrevistas realizadas nas empresas do setor bem como nas entidades do tecido institucional, ficou evidente a assimetria de poder existente entre as grandes empresas e as empresas de micro e pequeno porte do setor alimentício. Há um claro benefício às empresas de maior porte da cidade nas ações tomadas pelas entidades locais.

Este fato é passível de entendimento, já que são as grandes empresas que possuem um maior poder de barganha junto às entidades locais e aos órgãos ligados à administração do município, uma vez que as mesmas são responsáveis por $91 \%$ dos empregos gerados no município, além de certamente gerarem uma receita bastante considerável devido à arrecadação de impostos. Soma-se a isso o fato de serem justamente as empresas de maior que possuem maior aproximação das associações, e as empresas de menor porte manterem certo distanciamento das entidades locais, acarretando participação bastante reduzida em eventos e reuniões promovidas.

Assim, de acordo com as características apresentadas, pode-se notar o caráter excludente da rede de poder local, constituindo-se, então, em uma rede difusa, estando em formação e não apresentando representações coletivas definidas, com pulverizadas iniciativas para o compartilhamento de interesses entre seus membros. Este tipo de rede se caracteriza pela instabilidade e falta de continuidade das relações, devido a normas não formalizadas, que mudam conforme a necessidade ou a pressão dos atores.

\section{Políticas públicas:}

Com exceção ao Banco do Povo, que fornece empréstimos a pequenos empresários a juros reduzidos e com mínimas exigências de garantias formais por parte dos mesmos, nenhum outro tipo de ação advinda do poder público tem sido realizado no sentido de incentivar as MPE's em executar e aprimorar as suas operações. Ressalta-se, porém, que a falta de incentivos a empresas deste porte não se constitui apenas em uma questão local, mas nacional. 


\section{Selo de origem:}

Embora a Adima trabalhe com bastante afinco na divulgação do slogan "Marília Capital Nacional do Alimento", ressalta-se a importância da criação de normas para a formalização do selo junto aos órgãos específicos para esta normalização. Deste modo, a referida associação já possui um projeto embrionário para que esta ação seja concluída.

\section{Inovacão:}

Apesar aproximação já existente entre as universidades locais e as MPE's do município, tanto com a realização de pesquisas voltadas para as necessidades destas empresas quanto com a capacitação de mão-de-obra especializada, ainda falta muito para que haja uma atuação específica destes centros de pesquisa com relação à inovação destas empresas.

Além disso, o plano do Sesi em instalar uma cozinha industrial para servir como laboratório de desenvolvimento de produtos para as pequenas empresas, ainda está em projeto, não estando prevista data para a sua execução.

\section{Canais de distribuição:}

Entende-se que a promoção de consórcios de feiras de alimentação bem como a aquisição do selo local constituem-se em fatores que alavancarão a divulgação das empresas do município, fato que pode gerar maior facilidade na inserção deste conjunto de empresas em canais de distribuição mais fortes e consolidados. Porém, ressalta-se que estas ações devem ser melhor sistematizadas, para que as MPE's tenham suas participações garantidas nestas ações.

\section{Estrutura de rivalidade:}

Embora Porter (1991) afirme que a rivalidade entre empresas se constitui em um fator imprescindível para a alavancagem das mesmas, a rivalidade presente entre 
as empresas do setor configura uma questão preocupante, uma vez que esta pode comprometer a cooperação e a colaboração entre as empresas do cluster.

Ressalta-se que a tradição do município na produção de alimentos fez com que muitas das empresas do setor de alimentos tenham se originado pela abertura de um negócio por um funcionário após seu desligamento de uma outra empresa de alimentos, ou pelo desmantelamento de uma sociedade existente. Este fato faz com que a rivalidade seja grande entre empresas que atuam com a mesma linha de produtos.

Porém, este fator é atenuado pela grande variedade de linhas de produtos fabricados pelas empresas do cluster.

\section{Indústrias correlatas e de apoio:}

De acordo com a pesquisa preliminar realizada, dentre as principais dificuldades encontradas por este grupo de empresas estão a falta de laboratórios especializados em testes físico-químicos e microbiológicos nos produtos, a falta de empresas especializadas em manutenção, bem como de empresas locais fornecedoras de matérias-primas e de embalagem.

Pela porcentagem relativa de empresas que apresentaram tais reclamações, entende-se que o município possui deficiências com relação a empresas que prestam apoio e serviços às mesmas.

\section{Condicões de fatores:}

De acordo com dados publicados pela Prefeitura Municipal de Marília (1994), a área total do município de Marília é de $1.194 \mathrm{Km} 2$, sendo $42 \mathrm{~km} 2$ de área urbana e o restante de área rural.

Quanto à sua infra-estrutura, Marília conta com três fontes de abastecimento de água: Sistema Rio do Peixe (1800 m3/h), Sistema Represa Cascata (250m3/h) e Poço profundo Nova Marília (400 m3/h). Em 2002 foram inaugurados mais 3 poços

profundos, que fornecem mais de 300.000 litros por hora. Em termos de 
abastecimento de energia elétrica, o município conta com uma potência instalada de cerca de $100 \mathrm{MW}$, com uma reserva de mais de $40 \mathrm{MW}$ para ser utilizada.

Marília é servida por transporte rodoviário, ferroviário e aeroviário e, através do terminal intermodal de Pederneiras/SP, a cidade conta com a utilização de transporte hidroviário feito pelo Rio Tietê. Ainda sobre tranportes, 3 rodovias passam por Marília: BR 153 (Lins/Marília/Ourinhos), SP 294 (Bauru, Marília/Tupã) e SP 333 (Assis/Marília/Ribeirão Preto). Situada no centro-oeste do Estado, a privilegiada localização da cidade proporciona fácil acesso às principais cidades do Estado de São Paulo, Norte do Paraná, Mato Grosso do Sul e sul de Minas Gerais.

Salientam-se, ainda, a cultura do município voltada para a produção de alimentos e a presença no município de mão-de-obra especializada para a produção de alimentos.

Desta forma, pode-se concluir que o município apresenta condições infraestruturais favoráveis para as empresas industriais já existentes e para a instalação de futuras plantas fabris na cidade.

\section{Condicões de demanda:}

De acordo com a Adima (2003), as empresas do município possuem uma produção mensal estimada em 30.000 toneladas de produtos alimentícios. Cerca de $51 \%$ das empresas entrevistadas na Etapa I afirmam comercializar seus produtos na cidade e região e $49 \%$ delas voltam suas vendas outras localidades do país. Saber quais as condições específicas da demanda local para estes produtos mereceria um estudo mais aprofundado, envolvendo profissionais específicos da área de estudo de mercado.

\subsubsection{Considerações sobre os dados coletados na análise externa}

Pela análise dos dados coletados nesta parte da pesquisa, pode-se dizer que o ambiente institucional apresenta-se adequado para a articulação de ações que visem auferir para este conjunto de empresas todas as vantagens provenientes de um cluster. Algumas instituições já se destacam na promoção de ações para articular e 
beneficiar este conjunto de empresas, como é o caso da Adima, com suas iniciativas para a formação de consórcios e para a promoção do município como um centro nacional na produção de alimentos. Neste contexto, destaca-se também o Sebrae, com suas ações voltadas para a melhoria destas empresas, principalmente no que tange a capacitação destas empresas em seus aspectos gerenciais e o Senai, com a promoção de cursos de tecnologia de alimentos.

Há também uma aproximação interessante, embora ainda pequena, entre as empresas e as universidades, principalmente pela capacitação de profissionais para a atuação nestas empresas, com destaque à Unimar, na área tecnológica, com seu curso de Engenharia de Alimentos e à Fundação de Ensino na área administrativa.

Porém, o tecido institucional ainda não se encontra dotado de ações mais consistentes, cuja articulação seja integrada entre todas as entidades presentes no local. Além disso, o distanciamento das empresas de pequeno porte destas instituições e o seu desconhecimento sobre o que vem a ser um cluster, fazem com que as mesmas sejam pouco beneficiadas com as ações articuladas por estas instituições.

Ainda sobre MPE's, não foi notada nenhuma ação consistente e específica por parte destas instituições com relação ao auxílio para a aquisição de recursos financeiros, que se constitui no maior problema atual destas empresas.

\subsection{Análise geral do cluster alimentício de Marília/SP}

Diante do cenário configurado pelos dados das Etapas 1 e 2 desta pesquisa, pode-se afirmar que as MPE's do cluster alimentício de Marília possuem um baixo poder competitivo quando deparadas com os fatores que definem a competitividade para os dias atuais. Além disso, destaca-se baixa integração que estas empresas apresentam entre si, com os seus fornecedores e entre as instituições analisadas.

Com relação às entidades que compõem o tecido institucional, ressaltam-se as ações desempenhadas pelas entidades Adima, Senai e Sebrae com vistas a auferir a maior integração entre as empresas do município e a qualificação das mesmas com relação ao seu aprimoramento e capacitação para atingir um maior poder 
competitivo. Mas salienta-se que estas ações ainda são insuficientes e desarticuladas para auferir competitividade para o cluster.

Além disso, estas ações atingem mais as empresas de médio e grande porte do município, que se encontram mais integradas com as entidades locais, uma vez que possuem condições gerenciais e financeiras mais propícias para o aproveitamento dos benefícios destas ações.

Mediante este contexto, é possível afirmar que a atuação destas instituições ainda é pouco sistematizada, faltando às mesmas uma maior integração com outras entidades do município. Outro ponto importante a ser considerado é o fato destas instituições não levarem em consideração todos os aspectos que constituem um cluster completo, faltando ações mais holísticas e abrangente para elas.

Apesar das adversidades, porém, pode-se afirmar que as condições apresentadas pelo município de Marília configuram um perfil propício para o aproveitamento de todas as vantagens que existem em um cluster. Este se apresentaria como um fator dinamizador para a competitividade das empresas do cluster e, em especial, às MPE's, que teriam condições de atenderem às suas carências através da formação de parcerias entre si. Dentre estas condições destacamse:

$\checkmark \quad$ Concentração de empresas do mesmo ramo;

Atividades primárias pouco concentradas e, portanto, diversificáveis;

Presença de instituições de ensino;

$\checkmark \quad$ Entidade de classe voltada especificamente à indústria alimentícia (Adima);

$\checkmark \quad$ Cultura do município voltada para as atividades do cluster;

$\checkmark \quad$ Mão-de-obra especializada na produção de alimentos;

$\checkmark \quad$ Condições infra-estruturais adequadas para a instalação de novas empresas do ramo e de atividades complementares;

$\checkmark \quad$ Disposição das empresas para a realização de parcerias entre empresas concorrentes e fornecedores.

Aliada a estes fatores, a relevância destas empresas para o município também merece ser aqui destacada. Além das empresas processadoras de alimentos 
identificadas e pesquisadas, estima-se que existam outras 1.000 empresas relacionadas ao setor de alimentos no município, seja fornecendo materiais e serviços para este conjunto, seja comercializando os produtos produzidos pelas mesmas (Adima, 2003).

Neste sentido, pode-se dizer que a situação do conjunto de empresas presentes na cidade de Marília é, segundo a definição de Zaccarelli (2000), de um cluster incompleto. Analisando estas empresas de acordo com os nove itens apresentados pelo autor, obtém-se o resultado apresentado nas Tabelas 6.21 e 6.22.

TABELA 6.21: Características presentes no cluster de Marília

\begin{tabular}{|l|l|}
\hline \multicolumn{2}{|c|}{ Características presentes } \\
\hline $\begin{array}{l}\text { Alta concentração geográfica de empresas do } \\
\text { mesmo ramo }\end{array}$ & $\begin{array}{l}\text { No município existem cerca de } 58 \text { empresas processadoras } \\
\text { de alimentos e estima-se a existência de outras } 1000 \\
\text { empresas relacionadas ao setor. }\end{array}$ \\
\hline Empresas altamente especializadas & $\begin{array}{l}\text { Todas as empresas concentram em apenas uma ou duas } \\
\text { linhas de produtos distintas. }\end{array}$ \\
\hline $\begin{array}{l}\text { Cultura da sociedade adaptada às atividades de muitas empresas de cada tipo } \\
\text { do cluster }\end{array}$ & $\begin{array}{l}\text { Existem no município } 41 \text { linhas de produtos sendo } \\
\text { fabricadas. } \\
\text { alimentos. }\end{array}$ \\
\hline
\end{tabular}

TABELA 6.22: Características ausentes no cluster de Marília

\begin{tabular}{|c|c|}
\hline \multicolumn{2}{|r|}{ Características ausentes } \\
\hline $\begin{array}{l}\text { Total aproveitamento de materiais } \\
\text { reciclados e subprodutos }\end{array}$ & Este quesito não foi identificado no cluster em questão. \\
\hline $\begin{array}{l}\text { Existência de todos os tipos de } \\
\text { empresas e instituições de apoio } \\
\text { relacionados com o produto do } \\
\text { cluster }\end{array}$ & $\begin{array}{l}\text { Verificou-se a ausência de empresas fornecedoras de matérias- } \\
\text { primas e de empresas especializadas em análises laboratoriais, além } \\
\text { de empresas especializadas na fabricação de equipamentos e na } \\
\text { manutenção dos mesmos. }\end{array}$ \\
\hline Substituição seletiva permanente & $\begin{array}{l}\text { A maioria das empresas na cidade contam com um tempo de } \\
\text { existência acima de cinco anos, demonstrando a maturidade do setor. }\end{array}$ \\
\hline Uniformidade de nível tecnológico & $\begin{array}{l}\text { Há uma alta discrepância entre as empresas de médio e grande porte } \\
\text { do setor e as MPE's. }\end{array}$ \\
\hline Grande cooperação entre empresas & $\begin{array}{l}\text { Apesar de } 80 \% \text { das empresas entrevistadas mostrarem-se } \\
\text { interessadas na cooperação, esta ainda ocorre de forma incipiente. }\end{array}$ \\
\hline
\end{tabular}


Assim, para que o cluster de Marília venha a se tornar um cluster completo, há a necessidade da promoção de articulações que visem reforçar as características positivas do cluster já presentes na cidade. Além disso, as características ausentes como coordenação, objetivos em comum, descoberta de afinidades entre empresas, entre outros, devem ser paulatinamente introduzidos neste conjunto.

Destaca-se mais uma vez que o município já tem embutido em seus aspectos culturais a idéia de pólo alimentício. Isto é um ponto positivo com relação a uma futura exploração da questão da procedência (origem) como um atributo agregador de valor. Desta forma, mesmo que as empresas do ramo alimentício do município não venham a se clusterizarem, ainda assim a localização poderá ser explorada de forma positiva através de um "selo de origem" para os produtos produzidos na cidade. Para isto, ações no sentido de desenvolver mecanismos certificadores devem ser realizadas.

A figura 6.5, baseada no modelo geral para o desenvolvimento de um cluster apresentado por Casarotto Filho e Pires (1999), resume as entidades presentes e ausentes no cluster de Marília bem como suas interações.

Comparando a figura apresentada com o modelo sugerido por Casarotto Filho \& Pires (1999), algumas entidades importantes não existem no cluster de Marília, e necessitariam ser criadas. Além disso, muitas das interações apresentam-se fracas, necessitando de um trabalho mais específico para aumentar tais relações. 


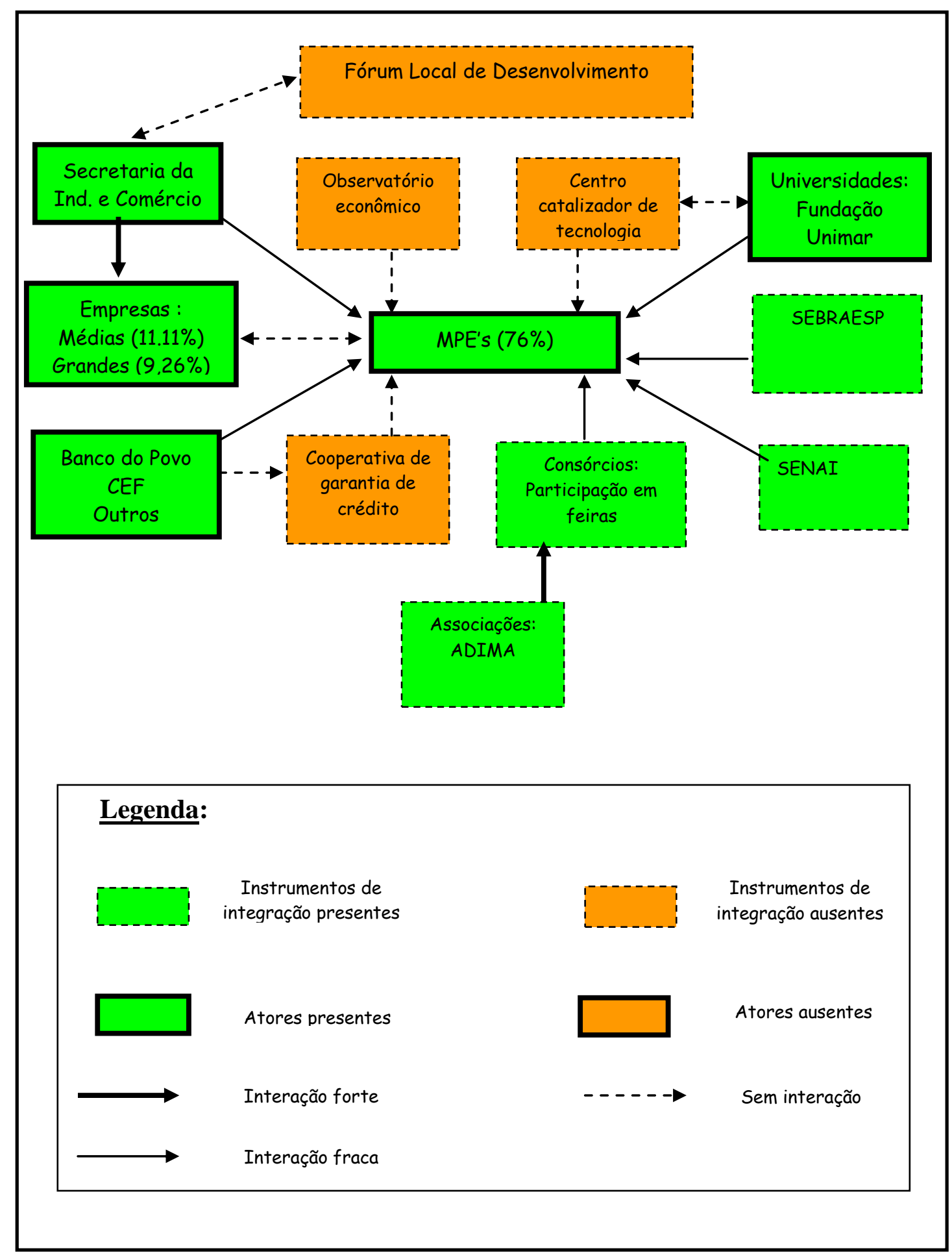

Figura 6.5.: Panorama geral do cluster alimentício de Marília/SP .Fonte: adaptado de Casarotto Filho \& Pires (1999) com dados coletados na pesquisa de campo. 


\subsection{Ações para a dinamização da competitividade do cluster}

Pelas dificuldades apresentadas pelas MPE's de alimentos do município, nota-se que ações no sentido de tornar este um cluster completo seriam capazes de beneficiá-las, tanto no em termos de promover cooperação entre elas, diminuindo com isso várias de suas incapacidades, quanto no aumento de sua capacidade em termos tecnológicos e de gestão.

Ações no sentido de capacitar as MPE's tanto em termos tecnológicos quanto em termos de gestão, para que haja uma uniformização do nível tecnológico das empresas locais, diminuindo, com isso, a assimetria de poder entre as MPE's e as MGE's do município.

Para tanto, inicialmente seria necessária a promoção da conscientização das empresas do cluster, em especial as MPE's, das vantagens que podem ser atingidas com o estabelecimento de um cluster completo bem como a integração das entidades locais, com a promoção de um Fórum de Desenvolvimento Local que definiria ações sistematizadas, quais sejam:

Incentivo ao setor primário na produção de matérias-primas voltadas a servirem de insumos para as empresas de alimentos locais, como o cultivo de amendoim, por exemplo;

Incentivos à instalação de empresas fornecedoras de matérias-primas necessárias para estas empresas;

$\checkmark \quad$ Incentivos à instalação de empresas produtoras de embalagens utilizadas por este conjunto;

Incentivos à instalação de empresas especializadas em manutenção de equipamentos;

$\checkmark \quad$ Maior integração com as universidades locais, para que haja uma aproximação mais efetiva entre elas e as empresa de alimentos no sentido de atenderem às especificidades desta indústria, tais como a produção de equipamentos voltados para a indústria de alimentação, a ser realizada pela equipe da Engenharia de Alimentos e Engenharia Mecânica da Unimar; utilização de laboratórios dos cursos de farmácia, biologia Nutrição em 
Engenharia de alimentos da Unimar para atender às empresas que não possuem laboratórios em suas plantas; utilização do escritório de Comércio Exterior da Fundação Eurípides para viabilizar as transações comerciais com outros países;

Incentivos para que as eventuais pequenas empresas informais do município venham a formalizarem suas atividades;

Criação de linhas de créditos específicas para as empresas de pequeno porte;

Facilidades para a aquisição por parte das MPE's de terrenos no Parque Industrial do município, visando que as mesmas possam possuir prédios próprios, já que a maioria delas possuem suas plantas em prédios alugados.

\subsection{Conclusão}

Este trabalho teve como hipótese que para o estudo da competitividade é possível elencar 3 níveis para que seja efetuada a sua análise: nível interno às empresas, nível relacionado aos aspectos ligados à cooperação entre as empresas do cluster e nível externo às empresas, relacionado às características de seu ambiente institucional. Desta maneira, pela análise realizada no cluster de alimentos de Marília/SP, pode-se notar a veracidade desta hipótese, uma vez que a análise da competitividade segundo estes 3 níveis se mostrou bastante didática para $o$ esclarecimento da competitividade do cluster em questão.

Quanto às proposições inicialmente apresentadas, ao contrário do que se pensava no início desta pesquisa, os baixos níveis de cooperação destas empresas não estão relacionados com a falta de confiança entre elas, mas exclusivamente à falta de informações sobre o conceito de cluster e sobre os reais benefícios da cooperação.

Por outro lado, pode-se afirmar que a falta de cooperação existente de fato afeta negativamente a competitividade das MPE's, já que estas poderiam incrementar os seus desempenhos através de parcerias com outras empresas, sejam elas para a compra conjunta de matérias-primas, para a troca de informações tecnológicas ou para a participação de consórcios de venda e distribuição de produtos.

Destaca-se, ainda, que, conforme outra proposição feita, de fato há a existência de assimetria de poder entre as MPE's e as empresas de médio e grande 
porte do município. Mas vale a pena lembrar que esta não é apenas fruto da falta de informações sobre os benefícios da cooperação, mas também do distanciamento existente entre as empresas de pequeno porte e as entidades do tecido institucional do município. 


\section{CONSIDERAÇÕES FINAIS E PERSPECTIVAS}

Sob o cenário da globalização, este trabalho levantou alguns aspectos relevantes que definem o atual ambiente dos negócios. Entre estes destacam-se a concorrência entre empresas, que agora passa a ser mundial; o aumento das exigências dos clientes por produtos e serviços que de fato tendam às suas necessidades; a operação das empresas em grandes cadeias mundiais; a emergência do Sistema de Produção Enxuta; a diversificação de produtos e serviços para adequação às necessidades específicas dos consumidores; e, por fim, a emergência de empresas focadas em suas core competences.

Para a atuação e sobrevivência neste novo cenário, as empresas devem operar afinadas com seguintes fatores definidores de competitividade: qualidade, custo, inovação, flexibilidade e desempenho nas entregas.

A emergência destes fatores competitivos define novas formas de atuação para as empresas, que devem estar capacitadas a operar neste novo contexto.

Porém, as empresas de pequeno porte, via de regra, se encontram em uma situação de desvantagem perante as grandes empresas para o alcance destes fatores competitivos. Desta maneira, destaca-se o surgimento de novas formas de organização, que, baseadas na cooperação entre empresas, garantem às MPE's a inserção no atual contexto dos negócios. Dentre as várias formas de cooperação existentes, os clusters foram aqui considerados como alternativa organizacional para a sobrevivência e projeção das empresas de pequeno porte.

Perante este contexto, neste trabalho foi estudado o cluster de alimentos da cidade de Marília/SP, através de sua caracterização e análise dos fatores competitivos das MPE's processadoras de alimentos nele presentes, bem como dos fatores competitivos de seu ambiente institucional.

Pela pesquisa realizada pode-se notar a baixa capacidade destas empresas em atingir os fatores competitivos vigentes e a falta de sistematização nas ações das instituições presentes no cluster. Desse modo, o cluster em questão foi classificado 
como um cluster incompleto, sendo proposto um elenco de ações a serem realizadas com o intuito de possibilitar que este venha a atingir o status de um cluster completo, beneficiando, sobretudo, as MPE's nele presentes.

Assim, dentre as principais contribuições deste trabalho, destacam-se:

* Caracterização/tipificação das empresas do cluster alimentício de Marília bem como das instituições nele presentes;

* Verificação da existência de iniciativas internas e externas às empresas direcionadas para alavancar a competitividade do cluster estudado;

* Confecção de um desenho geral do cluster, configurando as empresas e instituições presentes e ausentes no local;

* Sistematização da bibliografia dos assuntos relacionados ao estudo: competitividade, sistema agroalimentar/indústria brasileira de alimentos, micro e pequenas empresas e redes de cooperação (cluster);

* Confecção de um modelo geral para a orientação da análise da competitividade de aglomerados de empresas alimentícias, consistente com suas características e particularidades;

* Proposição de um elenco de atitudes que podem ser tomadas tanto pelas empresas (sobretudo as MPE's) quanto pelas instituições do referido cluster para que este venha a se tornar um cluster completo, refletindo no aumento de seu poder competitivo.

Espera-se, assim, que este trabalho tenha contribuído para traçar um panorama geral do cluster alimentício de Marília/SP e que este possa esclarecer, tanto às empresas quanto às entidades locais, os pontos fundamentais para que este conjunto venha a gozar de todas as vantagens de um cluster completo.

Ressalta-se, porém, que este estudo foi realizado apenas nas empresas processadoras de alimentos, não sendo pesquisadas as empresas fornecedoras de matérias-primas nem as empresas que trabalham apenas com a comercialização e a distribuição de produtos alimentícios. 
Torna-se relevante um estudo futuro que complemente este aqui realizado, que aprofunde na caracterização do cluster em questão, abrangendo empresas que possuem atividades complementares à indústria alimentícia. Assim, elenca-se na sequiência propostas para trabalhos futuros que venham a ser realizados neste conjunto de empresas:

$\checkmark \quad$ Realização de um projeto para a aquisição do selo local da produção de alimentos;

$\checkmark \quad$ Projeto de um desenho mais propício para o cluster estudado, configurando as relações mais apropriadas entre as entidades e as empresas do mesmo; Aplicação do modelo geral de pesquisa apresentado para o estudo de outros aglomerados de empresas.

Também seria importante que pesquisas posteriores que se desenvolvam a partir desta aqui apresentada, procurem explorar com mais profundidade o papel das políticas públicas e dos atores institucionais na configuração do cluster e na sua performance seja do ponto de vista do incremento de sua competitividade, seja da harmonização e equilíbrio de suas relações, buscando uma dinâmica satisfatória nos processos de cooperação.

Considera-se que estudos nesta direção, procurando evidenciar a necessidade e a importância da participação de agentes coordenadores e de políticas públicas direcionadas, são sobremaneira importantes quando se trata de MPE's, uma vez que esta classe de empresas possui peculiaridades que as tornam vulneráveis e, de certa forma, salientam sua dependência de ações que as promovam.

Finalmente, é preciso salientar que este trabalho apresenta como uma de suas principais contribuições a perspectiva de que, a despeito da indiscutível magnitude industrial e econômica representada pelas empresas alimentícias de médio e grande porte, as MPE's são uma alternativa viável de produção e que, mesmo com todos os suas limitações e problemas, constituem-se em um elo importante na cadeia produtiva e, neste sentido, merecem mais atenção em estudos desta natureza. 
ANEXO I

Roteiro de pesquisa Etapa 1 
Diagnóstico das Indústrias de Alimentos de Marília

Razão Social:

Nome fantasia:

End.: Bairro:

Tel.: fax:

e-mail: home-page:

Cidade: UF: CEP: C.G.C. / CPNJ: ( ) Informal

Contato(s) / Cargo:

\section{Porte:}

( ) Micro (faturamento até R $\$ 244.000,00 / a n o$ )

( ) Pequena (faturamento entre $\mathrm{R} \$ 244.001,00$ até $\mathrm{R} \$ 1.200 .000,00 / \mathrm{ano}$ )

( ) Média (faturamento entre $\mathrm{R} \$ 1.200 .001,00$ até $\mathrm{R} \$ 35.000 .000,00 / \mathrm{ano}$ )

( ) Grande (faturamento acima de $\mathrm{R} \$ 35.000 .000,00 / \mathrm{ano}$ )

2. Tempo de existência da empresa: anos

3. Número de funcionários:

4. Linha de produtos:

\begin{tabular}{|l|l|}
\hline Produto & $\begin{array}{c}\text { Participação nas } \\
\text { vendas (\% do } \\
\text { faturamento) }\end{array}$ \\
\hline & \\
\hline & \\
\hline & \\
\hline & \\
\hline & \\
\hline
\end{tabular}


5. Qual a área de atuação de vendas da empresa?

6. Quais são seus principais concorrentes?

Locais:

Nacionais:

Internacionais:

7. Quais as principais matérias-primas utilizadas?

\begin{tabular}{|c|c|}
\hline Produto & $\begin{array}{c}\text { Volume de compras mensal } \\
(\mathrm{Kg})\end{array}$ \\
\hline & \\
\hline & \\
\hline & \\
\hline & \\
\hline & \\
\hline & \\
\hline
\end{tabular}

8. Quais os seus principais fornecedores?

\begin{tabular}{|l|l|l|l|}
\hline Produto / Serviço & Fornecedor & Razão de compra & Localização \\
\hline & & & \\
\hline & & & \\
\hline & & & \\
\hline & & & \\
\hline & & & \\
\hline
\end{tabular}


9. Quais as principais dificuldades operacionais que a sua empresa enfrenta?

10. A empresa encontra dificuldades em:

- Compra de matéria-prima? Quais?

- Compra de embalagens? Quais?

- Compra de equipamentos? Quais?

- Manutenção de equipamentos? Quais?

- Análises laboratoriais? Quais? 
ANEXO II

Roteiro de pesquisa Etapa 2 -Parte A 
Perfil da Indústria de alimentos de Marília

Etapa 2 - Parte $A$

Pesquisa de campo

Data:

Empresa:

Endereço:

Contato:

Telefone:

Fax : e-mail:

\section{Características gerais}

1.1 Como se deu o surgimento da empresa?

1.2 Qual o critério de desempenho adotado?

1.3 Concorrência Mundial - tem havido aceno de ameaça internacional?

1.4 Tem aumentado a exigência dos clientes? Em qual(is) dos critérios?

\section{Infra-estrutura}

2.1 Idade do principal produto

2.2 Idade do principal equipamentos

2.3 Uso de Dispositivos (Microeletrônica)?

2.4 Prédio próprio?

\section{Tecnologia de Gestão}

- $\mathrm{RH}$

3.1 Como são as estratégias de Gestão de Recursos Humanos?

3.2 Como o treinamento tem sido aplicado?

- Qualidade

3.3 Como tem sido o uso de técnicas gerenciais?

3.4 Como tem sido a aceitação da ISO 9000?

3.3 Como é executado o CQ na Produção?

- Planejamento

3.4 A empresa possui estratégia formal?

3.5 Estratégia adotada 
3.6 Como tem sido obtidas as informações para a definição da estratégia?

3.7 Como são direcionadas as estratégias de mercado?

3.8 Como são distribuídas as estratégias para o exterior?

- Gestão financeira

3.9 Como são escolhidas as estratégias de financiamento?

\section{Pesquisa e Desenvolvimento}

\subsection{A empresa realiza PeD?}

4.2 A quanto tempo foi lançado o último produto da empresa?

4.3 Como tem sido efetuados os investimentos para maior competitividade?

\section{Logística de aquisições}

5.1 Como são orientadas as estratégias de compras?

5.2 Como são as relações com fornecedores no projeto de novos produtos?

5.3 Como tem sido o aporte de matérias-primas?

5.4 Tem programa de apoio aos fornecedores?

5.5 Possui confiança nos fornecedores?

5.5 possui parcerias com fornecedores?

6.1 Sistema de produção adotado

\section{Produção}

6.2 Como estão definidos os postos de trabalho?

\section{Logística de Distribuição}

7.1 Configuração da rede em que faz parte o negócio

7.2 Canal de distribuição

7.3 Maior parte das vendas para

7.4 Presença de varejistas (intermediários)? 


\section{Marketing}

8.1 Como são direcionadas as estratégias de produto?

8.2 Como é realizada a propaganda do produto?

8.3 Utiliza o selo "Marília capital do alimento"?

\section{Cooperação entre empresas}

9.1 Sabe o que é um cluster?

9.2 Participa de alguma forma de Cooperação?

9.3 Possui confiança em seus concorrentes?

9.4 Recebe algum tipo de ajuda das Associações?

9.5 Quais as impressões da empresa com relação às entidades: Secretaria da Indústria e do Comércio, Adima, Gead, Sindicato dos Trabalhadores da Indústria da Alimentação, Universidades, Sesi, Senai, Sebrae, Erplan e Ciesp?

9.6 A empresa já foi beneficiada com por alguma ação/iniciativa das entidades acima mencionadas? 


\section{ANEXO III}

Empresas da indústria alimentícia de Marilia/SP 


\begin{tabular}{|c|c|c|c|c|}
\hline Principais produtos & $\begin{array}{c}\% \\
\text { vendas }\end{array}$ & Empresa & $\begin{array}{l}\text { Número de } \\
\text { funcionários }\end{array}$ & Atuação de vendas \\
\hline $\begin{array}{l}\text { Amendoim (ovinho) } \\
\text { Goma (americana) }\end{array}$ & $\begin{array}{l}50 \\
50\end{array}$ & KIUTI & 50 & $\begin{array}{l}\text { SP, RJ, PR, SC, } \\
\text { RS }\end{array}$ \\
\hline $\begin{array}{l}\text { Amendoim } \\
\text { Doces de amendoim }\end{array}$ & $\begin{array}{l}50 \\
50\end{array}$ & YOKI & 280 & Brasil \\
\hline $\begin{array}{l}\text { Confeitos de amendoim } \\
\text { Bala de goma }\end{array}$ & $\begin{array}{l}70 \\
30\end{array}$ & KUKY & 165 & Brasil \\
\hline Confeitos de amendoim & 100 & TIKITOS & 10 & Grande SP \\
\hline $\begin{array}{l}\text { Confeitos de amendoim } \\
\text { Salgadinhos de trigo } \\
\text { Confeitos de açúcar }\end{array}$ & $\begin{array}{l}70 \\
10 \\
20\end{array}$ & DINGO & 29 & Brasil \\
\hline $\begin{array}{l}\text { Confeitos de amendoim } \\
\text { Confeitos em geral } \\
\text { Pirulitos } \\
\text { Balas }\end{array}$ & $\mathrm{N} / \mathrm{I}$ & DORI & 1200 & Brasil \\
\hline $\begin{array}{l}\text { Confeitos de amendoim } \\
\text { Balas } \\
\text { Aperitivos } \\
\text { Batata frita }\end{array}$ & $\begin{array}{l}70 \\
10 \\
10 \\
10\end{array}$ & YANK'S & 100 & Brasil \\
\hline $\begin{array}{l}\text { Confeitos de amendoim } \\
\text { Salgadinhos de trigo }\end{array}$ & $\begin{array}{l}\mathrm{N} / \mathrm{I} \\
\mathrm{N} / \mathrm{I}\end{array}$ & $\begin{array}{l}\text { MARIBALAS } * * * \\
\text { (Pequeno porte) }\end{array}$ & 25 & $\mathrm{SP}, \mathrm{NE}$ \\
\hline Pirulitos & 100 & CANDIMEL & 32 & Brasil \\
\hline $\begin{array}{l}\text { Pirulitos } \\
\text { Confeitos doces }\end{array}$ & $\begin{array}{l}50 \\
50\end{array}$ & DRIMAR & 23 & $\begin{array}{l}\text { Regiões Norte e } \\
\text { Nordeste }\end{array}$ \\
\hline $\begin{array}{l}\text { Tabletes (chocolates) } \\
\text { Marshmallow } \\
\text { Confeitos }\end{array}$ & $\begin{array}{l}60 \\
30 \\
10\end{array}$ & BEL & 480 & $\begin{array}{l}\text { Brasil } \\
\text { América } \\
\text { Central/N/S } \\
\text { outros }\end{array}$ \\
\hline $\begin{array}{l}\text { Cobertura para sorvete } \\
\text { Doce de mocotó }\end{array}$ & $\begin{array}{l}70 \\
30\end{array}$ & SWEET GEL & 4 & $\begin{array}{l}\text { Marília e região } \\
\text { Grande SP }\end{array}$ \\
\hline $\begin{array}{l}\text { Bala de coco } \\
\text { Bala de iogurte }\end{array}$ & $\begin{array}{l}70 \\
30\end{array}$ & COC FESTA & 7 & $\begin{array}{l}\text { Marília e região } \\
\text { PR e MT }\end{array}$ \\
\hline
\end{tabular}


...continuação

\begin{tabular}{|c|c|c|c|c|}
\hline $\begin{array}{l}\text { Nuts (nozes, amendoim, } \\
\text { amêndoas) } \\
\text { Caldas } \\
\text { Crocantes } \\
\text { Serviços para terceiros }\end{array}$ & $\begin{array}{l}70 \\
10 \\
10 \\
10\end{array}$ & CARINO & $\begin{array}{l}96 \\
\text { (mais terceirizados) }\end{array}$ & Mundial \\
\hline $\begin{array}{l}\text { Pamonhas } \\
\text { Suco de milho } \\
\text { Cural }\end{array}$ & $\begin{array}{l}60 \\
38 \\
2\end{array}$ & $\begin{array}{l}\text { PAMONHAS DONA } \\
\text { CLÁUDIA }\end{array}$ & 26 & $\begin{array}{l}\text { Estado de SP } \\
\text { Estado do RJ }\end{array}$ \\
\hline $\begin{array}{l}\text { Bombons } \\
\text { Salgados } \\
\text { Linha diet }\end{array}$ & 60 & DONDONNA & 14 & Marília \\
\hline $\begin{array}{l}\text { Bombons/bolos/tortas } \\
\text { Salgados }\end{array}$ & $\begin{array}{l}90 \\
10\end{array}$ & SONHOS E BEIJOS & 4 & Marília e região \\
\hline $\begin{array}{l}\text { Bombons } \\
\text { Bolos/tortas }\end{array}$ & $\begin{array}{l}65 \\
35\end{array}$ & LÉIA DOCES & 9 & Marília e região \\
\hline Doces (Quindim) & 100 & $\begin{array}{ll}\text { LÉIA } & \text { POMPEU } \\
\text { doces* } & \\
\end{array}$ & 1 & Marília \\
\hline Sorvetes & 100 & BAMBINELLA & 8 & Marília e região \\
\hline Salgados & 100 & $\begin{array}{l}\text { ROTISSERIE } \\
\text { L'AVENTURE }\end{array}$ & 6 & Marília \\
\hline $\begin{array}{l}\text { Salgados } \\
\text { Refeições prontas }\end{array}$ & $\begin{array}{l}80 \\
20\end{array}$ & DONA ELISA & 22 & Marília \\
\hline Salgados & 100 & CIREMAR & 4 & Marília e região \\
\hline $\begin{array}{l}\text { Salgados } \\
\text { Lanches } \\
\text { Pratos }\end{array}$ & $\begin{array}{l}80 \\
10 \\
10\end{array}$ & BABAHANUCH & 5 & Marília \\
\hline $\begin{array}{l}\text { Lanches } \\
\text { Salgados } \\
\text { Refeições }\end{array}$ & $\begin{array}{l}80 \\
10 \\
10\end{array}$ & IVONE* & 2 & Marília \\
\hline $\begin{array}{l}\text { Pães } \\
\text { Massa pizza } \\
\text { Outros }\end{array}$ & $\begin{array}{l}85 \\
5 \\
10\end{array}$ & SUPER PÃO & 9 & Marília (atacado) \\
\hline $\begin{array}{l}\text { Massas } \\
\text { Salgados } \\
\text { Refeições }\end{array}$ & $\begin{array}{l}40 \\
25 \\
35\end{array}$ & MASSAS NEGRI & 4 & Marília \\
\hline
\end{tabular}


...continuação

\begin{tabular}{|c|c|c|c|c|}
\hline $\begin{array}{l}\text { Massa para pastel } \\
\text { Massa para pizza frita }\end{array}$ & $\begin{array}{l}90 \\
10\end{array}$ & SÃO JOSË MASSAS & 8 & $\begin{array}{l}\text { Regiões Norte, CO } \\
\text { e Oeste }\end{array}$ \\
\hline Massas & 100 & ZARATINI & 9 & Marília e região \\
\hline Biscoitos doces/salgados & 100 & XERETA & 500 & $\begin{array}{l}\text { Brasil } \\
\text { Mercosul / Europa } \\
\text { Canadá / África }\end{array}$ \\
\hline Biscoitos doces & 100 & NESTLE & 550 & Brasil \\
\hline Biscoitos diversos & 100 & MARILAN & 1234 & $\begin{array}{l}\text { Brasil, Mercosul e } \\
\text { USA }\end{array}$ \\
\hline Biscoito de polvilho & 100 & $\begin{array}{l}\text { BISCOITOS } \\
\text { MARÍLIA }\end{array}$ & 6 & Estado de SP \\
\hline $\begin{array}{l}\text { Biscoito de polvilho } \\
\text { Pipoca de milho doce }\end{array}$ & $\begin{array}{l}50 \\
50\end{array}$ & DOCELAR & 10 & Marília e região \\
\hline Biscoito de polvilho & 100 & $\begin{array}{l}\text { BISCOITO } \\
\text { RODRIGO }\end{array}$ & 16 & Interior de SP \\
\hline Pipoca (doce/salgada) & 100 & BEIJA-FLOR & 3 & Marília \\
\hline $\begin{array}{l}\text { Pipoca de milho } \\
\text { Salgadinhos de trigo }\end{array}$ & $\begin{array}{l}70 \\
30\end{array}$ & PIPOCA DOÇURA & 3 & $\begin{array}{l}\text { Estados de SP, } \\
\text { MT e PR }\end{array}$ \\
\hline Salgadinhos de trigo & 14 & DUCK'S & 14 & $\begin{array}{l}\text { Marília, Regiões } \\
\text { Norte e NE }\end{array}$ \\
\hline Salgadinhos de trigo & 100 & LUCRIS & 26 & Brasil \\
\hline $\begin{array}{l}\text { Pele suína frita } \\
\text { Pele suína ressecada }\end{array}$ & $\begin{array}{l}80 \\
20\end{array}$ & LUCRIS & 7 & $\mathrm{SP}, \mathrm{MG}$ \\
\hline Leite e derivados & 100 & LEITERIA BRASIL & 5 & Marília \\
\hline Leite e derivados & 100 & COPLAP & 200 & $\begin{array}{lll}\text { Estado de } & \text { São } \\
\text { Paulo } & & \\
\end{array}$ \\
\hline Mussarela de búfala & 100 & $\begin{array}{l}\text { QUEIJOS DE } \\
\text { BÚFALO MARÍLIA }\end{array}$ & 5 & $\begin{array}{l}\text { São Paulo (capital) } \\
\text { Região de Marília } \\
\text { Ribeirão Preto }\end{array}$ \\
\hline $\begin{array}{l}\text { Mel } \\
\text { Derivados do mel }\end{array}$ & $\begin{array}{l}30 \\
70\end{array}$ & NATURI MEL & 2 & Marília \\
\hline $\begin{array}{l}\text { Mel } \\
\text { Derivados do mel }\end{array}$ & $\begin{array}{l}50 \\
50\end{array}$ & DOCE DULCE & Variável & Região de Marília \\
\hline Aromas & 100 & SUN FLAYVOURS & 3 & $\begin{array}{l}\text { Marília e região } \\
\text { Estados de MG, } \\
\text { GO, NE do Brasil }\end{array}$ \\
\hline
\end{tabular}


...continuação

\begin{tabular}{|c|c|c|c|c|}
\hline $\begin{array}{ll}\text { Refeições } & \text { diet } \\
\text { congeladas } & \\
\text { Cereais matinais } & \\
\end{array}$ & $\begin{array}{l}90 \\
10\end{array}$ & LEVE \& DIET & 4 & Região de Marília \\
\hline Polpa de fruta congelada & 100 & POLPA FRUITY & 5 & Região de Marília \\
\hline Refrigerantes & \begin{tabular}{|l|}
100 \\
\end{tabular} & SPAIPA (Coca-Cola) & 254 & $\begin{array}{l}\text { Centro-oeste } \\
\text { paulista } \\
\text { PR }\end{array}$ \\
\hline $\begin{array}{l}\text { Achocolatados (pó) } \\
\text { Especiarias } \\
\text { Farináceos }\end{array}$ & $\begin{array}{l}50 \\
30 \\
20\end{array}$ & GURILAR & 20 & Brasil \\
\hline Temperos & 100 & EL SHADAI & Familiar & Marília \\
\hline $\begin{array}{l}\text { Conservas } \\
\text { Sopas } \\
\text { Farináceos } \\
\text { Cereais } \\
\text { Chás } \\
\text { Molhos/temperos } \\
\text { Condimentos } \\
\text { Doces em vidro }\end{array}$ & $\mathrm{N} / \mathrm{I}$ & HIKARI & 500 & $\begin{array}{l}\text { Brasil } \\
\text { Japão }\end{array}$ \\
\hline Molho de soja & 100 & MARUYAMA & 11 & $\begin{array}{l}\text { Estados de SP, RJ, } \\
\text { PR e MS }\end{array}$ \\
\hline $\begin{array}{l}\text { Café } \\
\text { Café Express }\end{array}$ & $\begin{array}{l}80 \\
20\end{array}$ & $\begin{array}{ll}\text { CAFÉ } & \text { DO } \\
\text { FEIRANTE } & \end{array}$ & 5 & Marília e região \\
\hline $\begin{array}{l}\text { Ovos } \\
\text { Látex }\end{array}$ & $\begin{array}{l}95 \\
5\end{array}$ & $\begin{array}{l}\text { GRANJA } \\
\text { SHINTAKU** }\end{array}$ & 160 & $\begin{array}{l}\text { Regiões } \mathrm{CO}, \mathrm{N} \text { e } \\
\mathrm{NE}\end{array}$ \\
\hline
\end{tabular}

(*) Empresa Informal

(**) Empresa não-processadora

$(* * *)$ Empresa não pesquisada

Total de empresas não pesquisadas: 3 (Maribalas, Tutti e Intercofee) 


\section{REFERÊNCIAS BIBLIOGRÁFICAS}

ABIA O mercado brasileiro de alimentos industrializados. Associação Brasileira das Indústrias da Alimentação, Departamento Econômico, 1999.

ABIA Guia do setor alimentício 2002. Associação Brasileira das Indústrias da Alimentação, Departamento Econômico, 2001.

ADIMA Estatísticas. http://www.foods-adima.com.br/. (10/01/2003).

ALBERT, P.C. ; MUÑOZ, A C. G. Productos típicos, territorio y competitividad. Agricultura y Sociedad, n. 80-81, julio-diciembre, 1996.

AMATO NETO, J. Redes de cooperação produtiva: antecedentes, panorama atual e contribuições para uma política industrial. Tese (Livre Docência) Departamento de Engenharia de Produção - Universidade de São Paulo. São Paulo, 1999.

BATALHA, M. O.; SILVA, A. L. Gerenciamento de sistemas agoindustriais: definições e correntes metodológicas. In: BATALHA, M. O. et al. (Org.) Gestão Agroindustrial. São Paulo: Atlas, 2001. $2^{\mathrm{a}}$ ed. V.1.

BARROSO, I.C. Los nuevos espacios emergentes. Revista de estudios regionales. n. 50. Enero-Abril, 1998.

BARZEL, Y. Measurement Cost and Organization of Markets. Journal of law and economics, 25, April,1982.

BECCATINI, G. O distrito marshalliano. In: BENKO, G. ; LIPIETZ, A. (Org.) As regiões ganhadoras. Oeiras: Celta Editora, 1994.

BÉRARD, L. ; MARCHENAY, P. La construción social de los produtos de la tierra. Agricultura y Sociedad, n. 80-81, julio-deciembre, 1996, p.31-56.

BERTO, R.M.V.S.; NAKANO, D.N. Métodos de pesquisa na Engenharia de Produção. In: XVIII ENEGEP. Niterói, 1998. Anais.

BERTO, R.M.V.S. \& NAKANO, D.N. Produção científica nos anais do Encontro Nacional de Engenharia de Produção: um levantamento de métodos e tipos de pesquisas. In: XIX ENEGEP. Rio de Janeiro, 1999. Anais.

BIANCHI, P. Nuevo enfoque en el diseño de Políticos para las Pymes Aprendizado de la Experiência Europea. Documento de trabajo 72- CEPAL, 1996. 
BONANNO, A . A globalização da economia e da sociedade: fordismo e pósfordismo no setor agroalimentar. In: CAVALCANTI, J.S.B. (ORG) “Globalização, trabalho, meio ambiente". Recife: Universitária/UFPE, 1999.

BRASIL, Leis, etc. Lei Federal n. 9841 de 05 de outubro de 1999. Atribui o porte das empresas industriais de acordo com os critérios faturamento anual e número de funcionários. Estatuto da Micro e Pequena Empresa.

BREMER, C.F.; GUTIERREZ, A.M. Estrutura para negócios virtuais globais. In: XVIII Encontro Nacional de Engenharia de Produção. Niterói: UFF, TEP, 1998. Anais.

BRYMAN, A. Research Methods and Organization Studies. London: Routledge, 1989.

BRUNSTEIN, I. Controladoria e competitividade. In: Congresso Brasileiro de Gestão Estratégica de Custos, 1., 1994, São Leopoldo. Anais. São Leopoldo: Editora Unisinos, 1995. p.20-30.

BUZZELL, R.D.; ORTMEYER, G. Channel Partnerships Streamline Distribution. Sloan Management Review. Spring, 1995.

CABRAL, A.C.A. Novos arranjos cooperativos: alianças estratégicas e transferência de tecnologia no mercado global. In: RODRIGUES, S.B. (Org.) Competitividade, alianças estratégicas e gerência internacional. São Paulo: Atlas, 1999.

CAMPOMAR, M. C.; Do uso de "estudo de caso" em Pesquisa para Dissertações e Teses em Administração. Revista de Administração, v. 26 n. 3, julho/setembro 1991, p. 95-97.

CASAROTTO FILHO, N. ; PIRES, L.H. Redes de pequenas e médias empresas e desenvolvimento local. São Paulo: Atlas, 1999.

CERVO, A. L.; BERVIAN, P. A. Metodologia científica: para uso dos estudantes universitários. São Paulo: McGraw-Hill do Brasil, 1983. 3ed.

CHARAM, R. O uso das redes para redefinir as organizações e obter resultados. In: CHAMPY, J. ; NOHRIA, N. Avanço rápido: as melhores idéias sobre o gerenciamento de mudanças nos negócios. São Paulo: Campus, 1997. 
COURLET, C. ; PECQUEUR, B. Os sistemas industriais locais em França: um novo modelo de desenvolvimento. In: BENKO, G. ; LIPIETZ, A. (org.) As regiões ganhadoras. Oeiras: Celta Editora, 1994.

CRUZ, J; VACONCELlOS, V.; LEÓN, M.E; CASTILHO, F.; BREDA, F. Estratégias Globais das Empresas Transnacionais de Indústria Alimentícia no Brasil. In: XX Encontro nacional de Engenharia de Produção. EPUSP-São Paulo. Outubro/2000. $\underline{\text { Anais. }}$.

DANE, F. C. Research Methods. Brooks/Cole Publishing Company. Belmont, Califórnia: 1990.

DAVIS, J.H.; GOLDBERG, R. A concept of agribusiness. Harvard University Research Program Series. Harvard University Press, 1957. 60p.

FARINA, E.M.M.Q.; ZYLBERSZTAJN, D. Competitividade e organização das cadeias agroindustriais. IICA - Instituto Interamericano de Cooperação para a Agricultura. Costa Rica, 1994. 63p. (Relatório de Pesquisa).

FARINA, E.M.M.Q.; ZYLBERSZTAJN, D. Competitividade no agribusiness brasileiro. IPEA-PENSA, Relatório de pesquisa, Vol I. São paulo, 1998, 69p.

FLEURY, A \& FLEURY, M.T.L. Estratégias empresariais e formação de competências: um quebra-cabeça caleidoscópico da indústria brasileira. São Paulo: Atlas, 2000.

FRIEDMAN, H. Changes in the international division of labor: agri-food complexes and export agriculture. In: FRIEDLAND, W. et al. Towards a new political economy of agriculture. Boulder: Westview Press, 1991.

FREEMAN, C. The economics of industrial innovation. London: Macmillan, 1982.

GANNE, B. Significado e evolução dos sistemas industriais locais em França. In: BENKO, G. ; LIPIETZ, A. (org.) As regiões ganhadoras. Oeiras: Celta Editora, 1994.

GRANDORI, A. ; SODA, G. Inter-firm Networks: antecedents, mechanisms and forms. Organization Studies, n. 16, v. 2, 1995.

HARLAND, C. M.; LAMMING, R. C.; COUSINS, P. D. Developing the concept of supply strategy. International journal of operations \& production management. V.19, n.7, p. 650-673. 1999 
HUMPLREY, J.; SCHMITZ, H Trust and Inter-firm relations in developing and transition economies. The Journal of Development Studies. V.34. n.4, April,1998. p.32-61.

HUMPHREY, J.; SCHIMITZ, H. Governance and upgrading: linking industrial cluster and global value chain research. Institute of Development Studies (IDS), UK. 2000.

IBGE - Instituto Brasileiro de Geografia e Estatística. Censo das Empresas. http://www.ibge.org (23/01/2001).

INGLEY, C. The cluster concept: cooperative networks and replicability. $\underline{\text { In }}$ ICBS, Naples - Italy, June, 1999.

JARILO, J. C. Strategic Networks: Creating the Borderless Organization. Oxford: Butterworth Heinemann, 1998.

KANTER, R.M. When giants learn cooperative strategies. Planning Review, v.18, n.1, jan-fev, 1990.

KIDD, P. T. Agile Manufacturing - forging new frontiers. New York: AddisonWesley, 1994.

KIELSON, D. C. A new paradigm for competition. The Futurist. V.29, n.3, p.64, nov/dez, 1994.

KOTLER, P.; BLOOM, P. Marketing para serviços profissionais. São Paulo: Aatlas, 1988.

KRUGLIANSLAS, I. Tornando a pequena e média empresa competitiva. São Paulo: IEGE, 1996.

KRUGMAN, P.R.; OBSTFELD, M. Economia internacional: teoria e política. São Paulo: Makron Books, 1999.

LAGRANGE, L. La commercialisation des produits agricoles et alimentaires. $2^{\mathrm{a}}$ ed.Paris: Editora TECDOC. 1995.

LAKATOS, E. M.; ANDRADRE, M. A. Fundamentos de Metodologia Científica. 3 ed. Editora Atlas S.A. São Paulo. 1995. 270 p.

LAS CASAS, A . Plano de marketing para micro e pequenas empresas. São Paulo: Atlas, 2001. 2.ed.

LÈBRE, L. R. Perspectivas das Micro, Pequenas e Médias empresas no Brasil. Revista de Economia Contemporânea. Rio de Janeiro, 2001. 
LONGENECKER, J.G.; MOORE, C.W.; PETTY, J.W. Administração de pequenas empresas. São Paulo: Makron Books, 1998.

LOPEZ, A.; LUGONES, G. Los sistemas locales en en el escenario de la globalización. In: CASSIOLATO, J. E.; LASTRES, H. M. M. (ed.). Globalização e inovação localizada: experiências de sistemas locais no Mercosul. Brasília: IBICT/MCT, 1999. p. 72-108.

MARSHALL, A . Industry and Trade. Londres: MacMillan, 1919.

MARSHALL, C. \& ROSSMAN, G.B. Designing qualitative research. Sage: Thousand Oaks, 1995. 2.ed.

McCUNE, J. Não confie em ninguém: aprenda. HSM Management. 14 maio-jun., 1999. Vol. 15. n. 3.

MORVAN, Y. Fondements d'economie industrielle. Paris: Econômica, 1988.

MOTTA, F.G. Fatores condicionantes na adoção de métodos de custeio em pequenas empresas: estudo multicasos em empresas do setor metal-mecânico de São Carlos/SP. Dissertação (Mestrado) - Departamento de Engenharia de Produção - Escola de Engenharia de São Carlos - Universidade de São Paulo. São Carlos, 2000 .

NASSAR, A . M. Certificação no agribusiness. In: Cinco ensaios sobre gestão de qualidade no agribusiness. In: IX Seminário Internacional Pensa de Agribusiness. Águas de São Pedro/SP, 1999. Anais.

NAKANO, D.N.; FLEURY, A. Métodos de pesquisa em Engenharia de Produção.

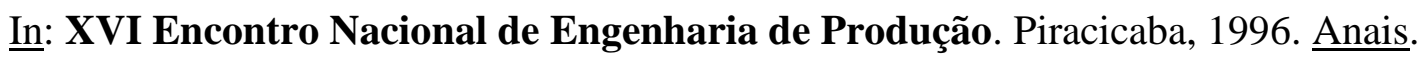
NEVES, M.F. Um modelo para planejamento de canais de distribuição no setor de alimentos. Tese (Doutorado) - Faculdade de Economia, Administração e Contabilidade - Universidade de São Paulo. São Paulo, 1999.

NEVES, M.F.; CHADDAD, F.R.; LAZZARINI, S.G. Alimentos - Novos Tempos e Conceitos na Gestão de Negócios. São Paulo: Editora Pioneira, 2000.

NOOTEBOOM, B. Inter-firm alliances - analysis and design. London: Routledge, 1999.

OLAVE, M.E.L.; AMATO NETO, J. Redes de cooperação produtiva: uma estratégia de competitividade e sobrevivência para as pequenas e médias empresas. Gestão e Produção, v.8, n.3, p.289-303, dez. 2001. 
PAROLINI, C. The value net: a tool for competitive strategy. Chichester: John Wiley \& Sons, 1999.

PAULILlO, L. F. Redes de poder e territórios produtivos. São Carlos: Rima, 2000 .

PIORE, M. ; SABEL, C. The second industrial divide. New York: Basic Books, 1984.

PLAWGO, B.; M. CHAPMAN The competitiveness of small and medium sized enterprises. In: Proceedings of International Conference of Small and Medium enterprises. ICBS 237. Naples - Italy. June, 1999.

PORTER, M. E. Vantagem competitiva: criando e sustentando um desempenho superior. Rio de Janeiro: Campus, 1990. 12.ed.

PORTER, M. E. Estratégia competitiva: técnicas para análise de indústrias e da concorrência. Rio de Janeiro: Editora Campus, 1991. 8.ed.

PORTER, M. E. Vantagem competitiva das nações. Rio de Janeiro: Campus, 1993.

PORTER, M. E. Clusters and the new economics of competition. Harvard Business Review. November-December, 1998.

PORTER, M.E. Competição: estratégias competitivas essenciais. Rio de Janeiro: Editora Campus, 1999. 7.ed.

PREFEITURA MUNICIPAL DE MARÍLIA. Dados e estatísticas sobre onde investir e crescer com a cidade. Marília/SP, 1994. Ifolder/

REVISTA VEJA. O crescimento das menores. São Paulo: Editora Abril, 26/01/2002. ed. 1734, ano 35, n.2. p.24.

RHODES, R. A .W. Policy networks: a British perspective. Journal of Theoretical Politics. London: Sage Publications, 1990.v.2. n.3.

RICHARDSON, R.J. Pesquisa social: método e técnicas. São Paulo: Atlas, 1984. RODRIGUES, I. C. ; VIEIRA, A C. O desenvolvimento de atributos e a adoção de certificados como iniciativa para aumentar a competitividade dos produtos agroindustriais nacionais no mercado externo: o caso do açúcar e suco de laranja concentrado orgânicos. In: I Jornada de institucionalismo e desenvolvimento da UFSCar. São Carlos/SP agosto, 2000. Anais. 
ROMANO, J.O . Interesses privados na formulação e implementação de políticas públicas para a agricultura. In: Silva, F.C.T.; Santos, R.; COSTA, L.F.C. Mundo rural e política: ensaios interdisciplinares. Rio de Janeiro: Campus, 1999.

SAES, M.S.M. Organizações e Instituições. In: ZILBERSZTAJN, D.; NEVES, M.F. (Orgs.) Economia \& Gestão dos Negócios Agroalimentares. São Paulo: Editora Pioneira, 2000.

SAIVES, A. L. ; BIENFANT, N. S. S'adapter aux exigences de flexibilite dans entreprises agroalimentaires par la construction de ressources territoriales. Nantes: Cahiers de Recherche - LAGERCIA, juin. 2000 SANTOS, S.A.; PEREIRA, H.J.; ABRAHÃO FRANÇA, S.E. Cooperação entre as micro e pequenas empresas, SEBRAE/SP, 1994.

SATO, G. S. (1997) Perfil da indústria de alimentos no Brasil: 1990-1995. Relatórios de Pesquisa, n.17. São Paulo: Fundação Getúlio Vargas.

SEBRAE- Programa SEBRAE de Desenvolvimento Local - Estudo realizado na Região Administrativa de Marília. In: Sumário Executivo. São Paulo, SP. Abril, 2001.

SEBRAE- Programas SEBRAE de Desenvolvimento. In: Sumário Executivo. São Paulo, SP. Março, 2002.

SILVA, A. L.; BATALHA, M. O. Marketing estratégico aplicado ao agronegócio. In: BATALHA, M. O. et al. Gestão Agroindustrial. São Paulo: Atlas, 2001. $2^{\mathrm{a}}$ ed. V.1.

SKINNER, W. Manufacturing - Missing Link in Corporate Strategy. Havard Business Review, v.47, n.3, p.136-145, 1969.

SOUZA, M. C.A., BACIC, J.M; COELHO, J.M. Gestão Estratégica de Custos e as Pequenas e médias empresas. In: Simpósio de Engenharia de Produção - SIMPEP - Unesp - Bauru, 2000. Anais.

SPROESSER, R.L. Gestão estratégica do comércio varejista de alimentos. In: BATAlHA, M. O. et al. (Org) Gestão Agroindustrial. São Paulo: Atlas, 2001. $2^{\mathrm{a}}$ ed. V.1.

VIGLIO, E. C. B. L. Indústria de alimentação: características e tendências para o ano de 2000. Agroanalysis, p. 6-12. Setembro, 1996.

WEBER, M. Economia e Sociedade. Brasília: Editora da UnB, 1991. 
WELSH, S.A.; WHITE, S.F. A small business is not a little big business. Harvard Business Review, p.18-32, July-Aug, 1981.

WESTBROOK, R. Action Research: a new paradigm for research in production and operations management. International Journal of Production and Operations Management, V.15, n.12, p.6-20, 1995.

YIN, R.K. Case study research: design and methods. Sage: Thousand Oaks, 1994, 2.ed.

ZACCARELLI, S. B. Estratégia e sucesso nas empresas. São Paulo: Saraiva, 2000.

ZYLBERSZTAJN, D. ; NEVES, M.F. Economia \& gestão dos negócios agroalimentares. São Paulo: Pioneira, 2000. 


\section{BIBLIOGRAFIA CONSULTADA}

BENKO, G.; LIPIETZ, A . As regiões ganhadoras - distritos e redes. Oeiras: Celta Editora, 1994.

BOYER, R. A teoria da regulação: uma análise crítica. São Paulo: Nobel, 1990.

CASABURI, G.G. Dynamic Agroindustrial Clusters - the political economy of competitive sectors in Argentina e Chile. London: St. Martin's Press, 1999.

COOPER, M. C.; LAMBERT, D. M.; PAGH, J. D. Supply Chain Management: more than a new name for logistics. The International Journal of Logistics Management, 1997. V.8 n.1.

DOZ, Y. L. ; HAMEL, G. A vantagem das alianças - a arte de criar valor através das parcerias. Rio de Janeiro: Qualitymark, 2000.

FARINA, E.M.M.Q. Padronização em Sistemas Agroindustriais. In: IX Seminário Internacional PENSA de Agribusiness . Águas de São Pedro - SP, 1999. Anais.

FERDOWS, K. Making the most of foreign factories. Harvard Business Review, March-April, 1997. p. 73-88.

GATTORNA, J. L. ; WALTERS, D. W. Managing the Supply Chain: a Strategic Partnership. London: Macmillan Press, 1996.

HANDFIELD, R. B. ; NICHOLS Jr, E. L. Intoduction to Supply Chain Management. New Jersey: Prentice-Hall, 1999.

LAMMING, R. et al. An initial classification of supply networks. International journal of operations \& production management. V.20, n.6, p. 675-691. 2000.

LEÓN. M. E. ; AMATO NETO, J. Simulating regional development and SME's clustering: an alternative for emerging economies. In: First World Conference on Production and Operations Management - POM. Sevilla, 2000.

LORANGE, P. ; ROOS, J. Alianças estratégicas - formação, implementação e evolução. São Paulo: Atlas, 1996.

MARTIN, C. Logística e Gerenciamento da Cadeia de Suprimentos. São Paulo: Pioneira, 1997. 
MULLER, G. Competitividade e integração econômica e social: para uma gestão regional das questões agrárias e agroindustriais. Rascunho, IGCE-UNESP, Rio Claro, n. 32, 1995.

RHODES, R. A . W.; MARSH, D. New directions in the study of policy networks. European Journal of Political Research. v.21. 1992.

RODRIGUES, A. M.; J. P. A. FUSCO Regional Clusters: a case study among Brasilian food companies. In: Production and Operation Management Conference - POM. San Francisco, USA, 2002.

SLACK, N. et al. Operations Management. London: Pitman Publishing, 1998. 2. ed.

VIEIRA, A .C. Agronegócios: Tendências. Departamento de Engenharia de Produção-UFSCar (mimeo). 2001

ZILBOVICIUS, M. Modelos para a produção, produção de modelos: contribuição à análise da gênese, lógica e difusão do modelo japonês. Tese (Doutorado). Escola Politécnica - Universidade de São Paulo. São Paulo, 1997. 
